\title{
INJEÇÃO DE SOLO-CIMENTO EM SOLO RESIDUAL DE GRANITÓIDE: uma proposta de análise com suporte estatístico e avaliação da eficiência com método geofísico
}

WILSON SHOJI IYOMASA

Tese apresentada à Escola de Engenharia de São Carlos, da Universidade de São Paulo, como parte dos requisitos para obtenção do Título de Doutor em Geotecnia.

ORIENTADOR: Prof. Dr. José Eduardo Rodrigues

Volume 1

São Carlos

2000 


\section{FOLHA DE APROVAÇÃO}

Autor: Wilson Shoji Iyomasa

Título: Injeção de solo-cimento em solo residual de granitóide: uma proposta de análise com suporte estatístico e avaliação da eficiência com método geofísico

Tese defendida e aprovada em 07/04/2000 pela Comissão Julgadora

Coordenador da Área de Geotecnia

Presidente da Comissão de Pós-

Graduação 
Aos meus pais e à Analice, minha esposa.

Às Larissa e Amanda, nossas filhas. 


\section{AGRADECIMENTOS}

Ao amigo Prof. Dr. José Eduardo Rodrigues, orientador desta pesquisa, pelo incentivo, estímulo, dispêndio de tempo para leitura e discussão do texto produzido e pelas sugestões apresentadas.

Ao Instituto de Pesquisas Tecnológicas do Estado de São Paulo - IPT, pela oportunidade na elaboração desta tese.

À estatística Lúcia Dozzi, pelas lições de estatística e pelas discussões dos resultados matemáticos.

Ao engenheiro Kenji Matsuda (in memoriam) e aos técnicos Aroldo Silva, Francisco Brito e Waldyr Cortez, pelo auxílio oferecido na montagem do banco de dados informatizado e pela elaboração das figuras e transparências.

Aos geólogos Antonio Marrano e Amarílis Gallardo, pela leitura e sugestões no texto.

À secretária Lúcia Solera e à editora Vilma Varalta, pelo auxílio na impressão e correção do texto.

À Empresa Metropolitana de Águas e Energia S.A., antiga Eletropaulo Eletricidade de São Paulo, nas pessoas dos engenheiros Rodinei Pereira e Jorge Goto, e à Progeconsult, na pessoa do engenheiro Orlando dos Santos, por permitirem a divulgação dos dados técnicos.

Expresso, ainda, meus agradecimentos a todos que, de uma maneira ou de outra, permitiram a realização deste trabalho. 


\section{Volume 1}

SUMÁRIO

p.

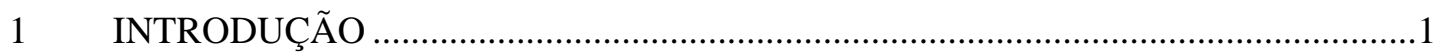

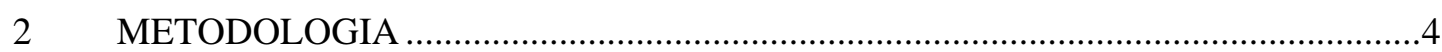

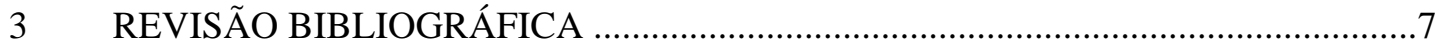

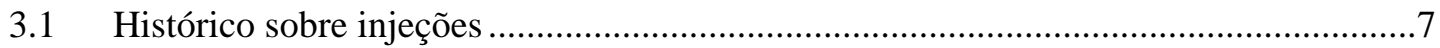

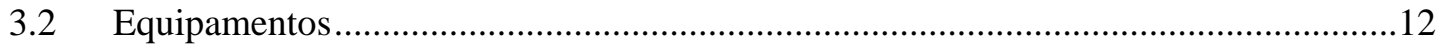

3.3 Propagação de fraturas induzidas por fraturamento hidráulico ....................................17

3.4 Regime de escoamento das caldas de injeção ..............................................................27

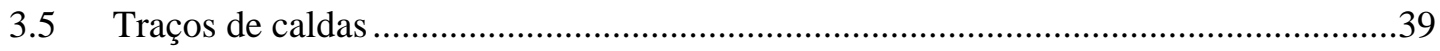

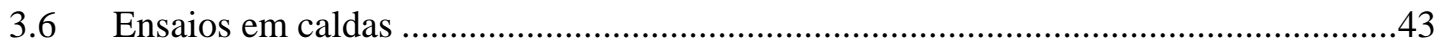

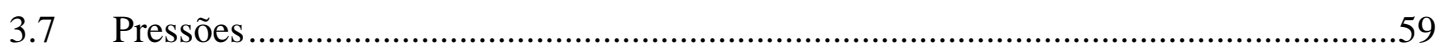

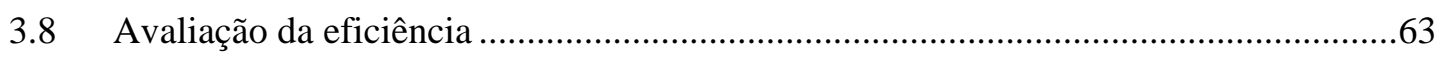

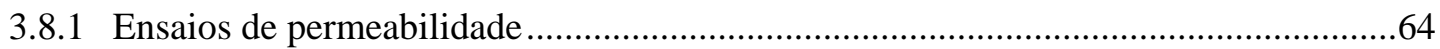

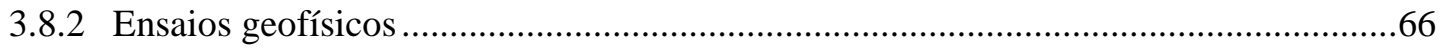

4 INJEÇÕES DE SOLO-CIMENTO EXECUTADAS EM OUTRAS OBRAS BRA-

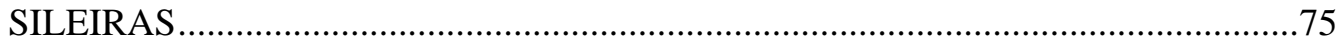

$4.1 \quad$ Barragem de Balbina .........................................................................................

4.1.1 Síntese dos aspectos geológico-geotécnicos ................................................................76

4.1.2 Problemas geológico-geotécnicos encontrados.............................................................78

4.1.3 Projeto de tratamento da fundação da barragem ........................................................79

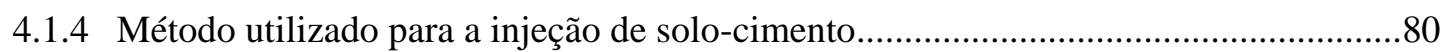

4.1.4.1 Perfuração e instalação dos tubos com válvula manchete............................................82

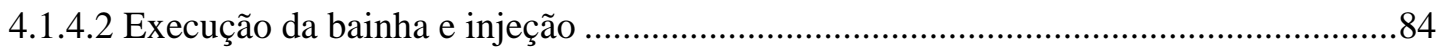

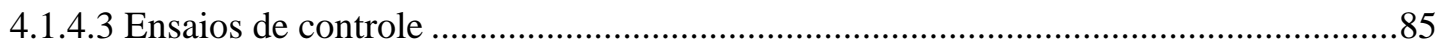

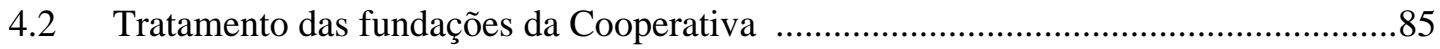

4.2.1 Aspectos geológico-geotécnicos e problemas encontrados ............................................86

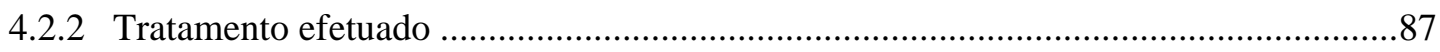

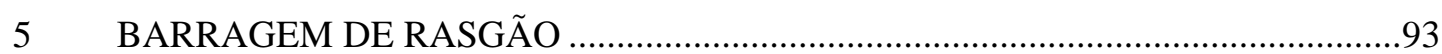

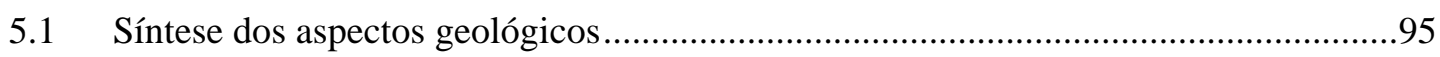

5.2 Problemas encontrados e soluções propostas.............................................................97

5.3 Características gerais do projeto de tratamento..........................................................103

5.3.1 Cortina de vedação.....................................................................................................104 


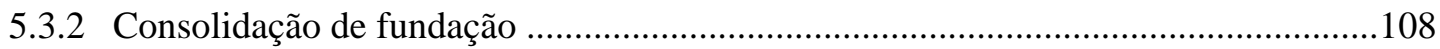

5.4 Trabalhos realizados para a injeção de solo-cimento..............................................109

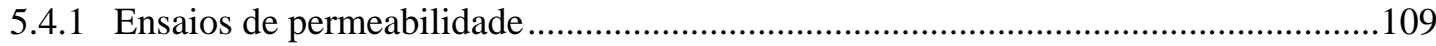

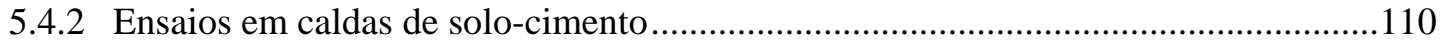

5.4.3 Perfuração e instalação dos tubos com válvula manchete..............................................115

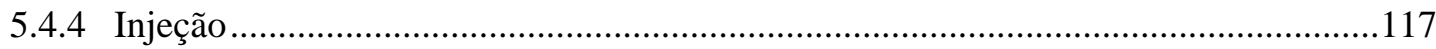

5.5 Testes realizados na cortina de vedação e no campo de prova ....................................118

5.5.1 Variação das pressões em diferentes fases de injeção................................................119

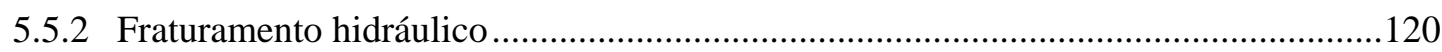

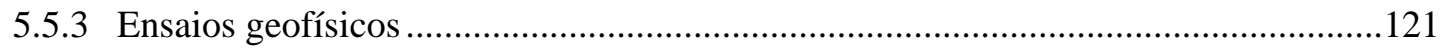

5.5.3.1 Aspectos geológico-geotécnicos do local ...............................................................122

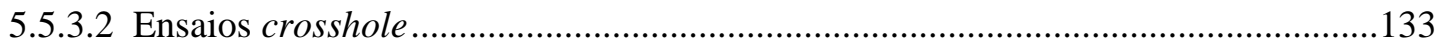

5.5.3.3 Execução das injeções..........................................................................................137

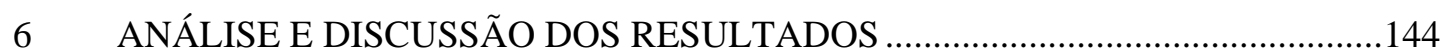

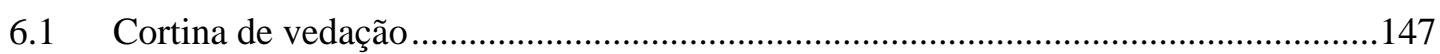

6.1.1 Análise das pressões de ruptura e de injeção por fases de tratamento ........................149

6.1.2 Análise das pressões nas diferentes ordens de tratamento .........................................158

6.1.2.1 Nas duas camadas do solo residual (superior e inferior) ..........................................163

6.1.2.2 Na camada do solo residual superior ....................................................................176

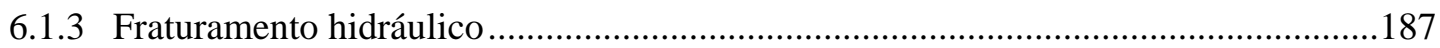

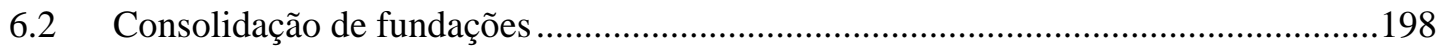

6.3 Eficiência do tratamento ...........................................................................................202

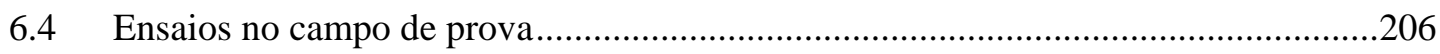

6.4.1 Aspectos gerais do terreno e do tratamento realizado...............................................208

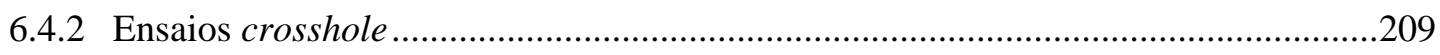

6.4.2.1 Análise estatística dos resultados geofísicos............................................................210

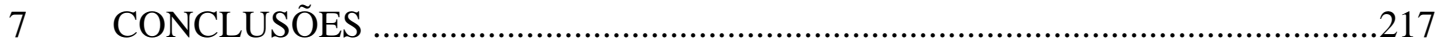

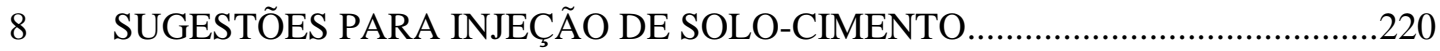

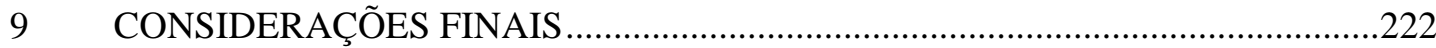

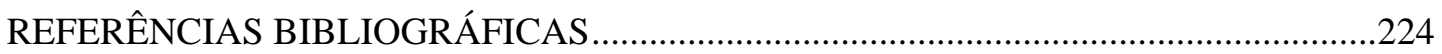




\section{LISTA DE FIGURAS}

FIGURA 1 - Equipamentos de perfuração movidos a ar comprimido (rotopercussiva), com pneus para locomoção...

FIGURA 2 - Válvula-manchete.

FIGURA 3 - Disposição esquemática dos componentes necessários para montagem do tubo de PVC com válvula-manchete..

FIGURA 4 - Obturador de anel utilizado em injeções com válvula-manchete.

FIGURA 5 - Mecanismo de fraturamento hidráulico obtido em corpos-de-prova (HUBBERT \&WILLIS, 1957).

FIGURA 6 - Representação esquemática do fraturamento hidráulico (a) e da obtenção da impressão da fratura (b) (ISRM, 1987).

FIGURA 7 - Forma da extremidade da fratura induzida: (a) segundo a Teoria da Elasticidade e (b) segundo BARENBLATT (1962)..

FIGURA 8 - Corte transversal de uma cavidade cilíndrica de raio igual a $\mathrm{R}$, fraturas com comprimento $2 \mathrm{~L}$, submetidas à pressão hidrostática $(\mathrm{P})$ e tensões $\sigma_{1}$ e $\sigma_{2}$ (HAYASHI \& SAKURAY, 1989).

FIGURA 9 - Distribuição de pressão neutra (HAYASHI \& SAKURAY, 1989)....

FIGURA 10 - Experiência de Reynolds (BARRADAS, 1985).

FIGURA 11 - Reograma característico dos fluidos: (a) Newtoniano; (b) Binghamiano; (c) e (d) PseudoPlástico (BARRADAS, 1985)...

FIGURA 12 - Escoamento laminar em tubo cilíndrico (BARRADAS, 1985).........

FIGURA 13 - Fluxo entre duas placas paralelas perfeitamente polidas (QUADROS, 1982).

FIGURA 14 - Distribuição de velocidades entre placas paralelas: a) laminar e b) turbulento (QUADROS, 1982).

FIGURA 15 - Comportamento da calda com o tempo de hidratação da bentonita (BARBI et al., 1981).....

FIGURA 16 - Viscosímetro Fann empregado no laboratório para determinação de caldas de cimento

FIGURA 17 - Curva viscosimétrica do modelo Bingham plástico

FIGURA 18 - Cone ou funil utilizado no ensaio para determinação do tempo de escoamento

FIGURA 19 - Aparelho de Vicat para determinação do início de pega da calda.....

FIGURA 20 - Diagrama triangular obtido por HOLANDA \& GUEDES (1981)....

FIGURA 21 - Granulometria teórica recomendada (PITTA, 1984).

FIGURA 22 - Determinação do tempo de escoamento em função do teor de cimento e do conteúdo de água (PITTA, 1984). 
FIGURA 23 - Determinação gráfica do teor de cimento para a contração volumétrica (PITTA, 1984).

FIGURA 24 - Determinação do conteúdo de água final para o teor de cimento ótimo (PITTA, 1984)

FIGURA 25 - Resistência à compressão simples da calda solidificada para diversos teores de cimento (PITTA, 1984).

FIGURA 26 - Valores relativos das pressões no tratamento efetuado em Balbina: a) e b) para bainhas mais resistentes que o solo e c) bainha com resistência menor ou semelhante ao do solo (SANTOS et al., 1985)

FIGURA 27 - Aumento médio da pressão em função das fases de injeção no tratamento de maciço para escavação de túnel urbano (GUIMARÃES FILHO, 1984)

FIGURA 28 - Aumento médio da pressão em função das fases de injeção para tratamento de fundação de edifícios (GUIMARÃES FILHO, 1984)...

FIGURA 29 - Determinação de velocidade num estrato sísmico. A fonte de energia (F) e o receptor (R) localizam-se no estrato intermediário (PRADO, 1994)

FIGURA 30 - Mapa de localização da barragem de Balbina (BARRADAS, 1985)

FIGURA 31 - Projeto para tratamento com injeção para impermeabilização do maciço na barragem de Balbina (MOREIRA et al., 1990).....

FIGURA 32 - Localização das edificações na unidade industrial da Cooperativa Central de Laticínios..

FIGURA 33 - Seção típica na área do tratamento (PROGECONSULT, 1997).......

FIGURA 34 - Planta geral da área da Usina de Rasgão

FIGURA 35 - Mapa geológico simplificado da região da barragem de Rasgão (IPT, 1984b modificado).

FIGURA 36 - Seção geológica na tomada d'água da Usina de Rasgão

FIGURA 37 - Seção geológica na região da casa de força.

FIGURA 38 - Vista geral do conjunto de geração da Usina de Rasgão.

FIGURA 39 - Planta geral do tratamento efetuado por injeção de solo-cimento na Usina de Rasgão.

FIGURA 40 - Corte da área dos tratamentos com injeção de solo-cimento.

FIGURA 41 - Curvas granulométricas dos materiais das áreas de empréstimo: 1 área EN; 2 área STA e 3 limites estabelecidos por PITTA (1984)..

FIGURA 42 - Croqui do campo de prova da Usina de Rasgão.

FIGURA 43 - Perfil individual de sondagem a trado.....

FIGURA 44 - Perfil individual de sondagem a trado.

FIGURA 45 - Perfil individual de sondagem a trado.

FIGURA 46 - Perfil individual de sondagem a trado. 
FIGURA 48 - Perfil individual de sondagem a percussão.

FIGURA 49 - Perfil individual de sondagem a percussão.

FIGURA 50 - Seção geológico-geotécnica do campo de prova..

FIGURA 51 - Volume de calda de solo-cimento injetado por válvula manchete nos furos do campo de prova.

FIGURA 52 - Pressões de ruptura das válvulas manchete ao longo dos furos.

FIGURA 53 - Pressões de injeção ao longo dos furos.

FIGURA 54 - Caldas de solo-cimento com corantes para avaliar forma, persistência, freqüência e relação entre fraturas hidráulicas.

FIGURA 55 - Ocorrência de matacões alterados, ou núcleos de rocha alterada, nas paredes do poço E2.

FIGURA 56 - Histogramas da pressão de iniciação da ruptura do maciço (Pr) nas duas fases de injeção..

FIGURA 57 - Histogramas da pressão de injeção (Pi) nas duas fases de injeção....

FIGURA 58 - Variação das pressões de ruptura e de injeção ao longo dos furos, na cortina de vedação da obra de Rasgão.

FIGURA 59 - Variação da pressão de ruptura, nas três linhas injetadas, nas duas camadas do solo residual

FIGURA 60 - Variação da pressão de injeção, nas três linhas injetadas, nas duas camadas do solo residual.

FIGURA 61 - Variação dos valores médios da pressão de iniciação da ruptura com a profundidade, nas linhas primária, secundária e terciária, nas duas camadas do solo residual.

FIGURA 62 - Variação dos valores médios da pressão de injeção com a profundidade, nas linhas primária, secundária e terciária, nas duas camadas do solo residual.

FIGURA 63 - Variação dos valores médios da pressão de iniciação da ruptura com a profundidade, nas linhas primária, secundária e terciária, na camada superior do solo.

FIGURA 64 - Variação dos valores médios da pressão de injeção com a profundidade, nas linhas primária, secundária e terciária, na camada superior do solo

FIGURA 65 - Variação da pressão média durante os ensaios de ruptura hidráulica do maciço terroso.

FIGURA 66 - Fraturas hidráulicas na vertical e uma na horizontal, preenchidas com calda de solo-cimento endurecida, observadas no poço E2.

FIGURA 67 - Imagem extraída da bainha de um furo no campo de prova.

FIGURA 68 - Intersecção da calda de solo-cimento (cor clara) com duas fraturas reliquiares do maciço (cor escura), sem que ocorresse interferência, observada no poço E2.

FIGURA 69 - Variação dos valores médios das pressões de iniciação da ruptura do maciço e de injeção no tratamento de consolidação da Usina de Rasgão. 
FIGURA 70 - Planta geral da área da Usina de Rasgão com esboço geológico......

FIGURA 71 - Gráficos dos tempos da onda sísmica S entre os pares PAR 1, PAR 2 e PAR 3, antes e depois do tratamento com injeção de solo-cimento, no campo de prova da Usina de Rasgão 


\section{LISTA DE TABELAS}

TABELA 1 - Valores médios das proporções dos materiais usados na confecção de caldas por obra ( $\mathrm{a}$ = água; $\mathrm{ag}=$ argila; e cim. = cimento).

TABELA 2 - Classificação dos ensaios de permeabilidade em solo (ABGE, 1981)

TABELA 3 - Características médias das caldas utilizadas nos experimentos na fundação da barragem de Balbina (BARRADAS, 1985).

TABELA 4 - Volume de calda utilizada no tratamento da fundação do laboratório.

TABELA 5 - Volume de calda utilizada no tratamento das fundações da caixa d'água e casa das caldeiras

TABELA 6 - Resultados dos ensaios de infiltração realizados na Usina de Rasgão

TABELA 7 - Resultados dos ensaios realizados nos solos das áreas de empréstimo STA e EN.

TABELA 8 - Características médias das caldas preliminares ensaiadas na obra de Rasgão

TABELA 9 - Valores médios dos parâmetros das caldas ensaiadas na obra de Rasgão.

TABELA 10 - Tempo de propagação das ondas $S$ entre pares de furos, no campo de prova da Usina de Rasgão.

TABELA 11 - Tempo de propagação das ondas P entre pares de furos, no campo de prova da Usina de Rasgão.

TABELA 12 - Comparação entre velocidades das ondas S, obtida entre pares de furos e na cortina de injeção, no campo de prova da Usina de Rasgão.

TABELA 13 - Valores médios dos parâmetros das caldas utilizadas no campo de prova.....

TABELA 14 - Freqüência da distribuição e localização das manchetes não rompidas.

TABELA 15 - Valores das pressões de ruptura (Pr) e de injeção (Pi) das duas fases de injeção.

TABELA 16 - Resultados dos cálculos estatísticos das pressões nas duas fases de injeção

TABELA 17 - Resultados do teste t para duas amostras em par para médias das pressões de ruptura e de injeção, considerando duas fases de injeção.

TABELA 18 - Estatística da pressão de ruptura em cada uma das linhas injetadas, em diferentes níveis de profundidades, nas duas camadas de solo residual de granitóides.

TABELA 19 - Estatística e média da pressão de ruptura nas três linhas injetadas, em diferentes níveis de profundidades, nas duas camadas de solo residual de granitóides. 
TABELA 20 - Resultados da análise de variância com fator duplo sem repetição para a pressão de iniciação da ruptura do maciço.

TABELA 21 - Estatística da pressão de injeção em cada uma das linhas, em diferentes intervalos de profundidades, nas duas camadas de solo residual de granitóides.

TABELA 22 - Estatística e média da pressão de injeção nas três linhas injetadas, em diferentes intervalos de profundidades, nas duas camadas de solo residual de granitóides.

TABELA 23 - Resultados da análise de variância com fator duplo, sem repetição e de modelo fixo para a pressão de injeção, nas duas camadas do solo residual.......

TABELA 24 - Valores médios da pressão de iniciação da ruptura do maciço, na camada superior do solo.

TABELA 25 - Valores médios da pressão de iniciação da ruptura do maciço, nos intervalos de profundidades e nas linhas, na camada superior do solo.

TABELA 26 - Resultados da análise de variância com fator duplo, sem repetição e de modelo fixo para a pressão de iniciação da ruptura do maciço.

TABELA 27 - Valores médios da pressão de injeção em cada uma das linhas, nos diferentes intervalos de profundidades, na camada superior do solo.

TABELA 28 - Valores médios da pressão de injeção, nos intervalos de profundidades e nas linhas, na camada superior do solo...

TABELA 29 - Resultados da análise de variância com fator duplo, sem repetição para a pressão de injeção do maciço..

TABELA 30 - Resultados da estatística descritiva das pressões: $\mathrm{P}_{\mathrm{r}} \mathrm{P}_{\mathrm{i}} \mathrm{P}_{\mathrm{c} 1}$ e $\mathrm{P}_{\mathrm{p}}$ (MPa).

TABELA 31 - Resultados do teste $t$ (duas amostras em par) para os valores médios das pressões de ruptura da bainha e da segunda ruptura; de injeção e de paralisação; e de paralisação e de ruptura da bainha.....

TABELA 32 - Valores médios das pressões do tratamento da Cooperativa (PROGECONSULT, 1997).

TABELA 33 - Valores médios do coeficiente de permeabilidade antes e após a construção da cortina de vedação na Usina de Rasgão

TABELA 34 - Comparação efetuada entre os coeficientes de permeabilidade (antes e depois) por meio do teste t para duas amostras, presumindo variâncias diferentes.

TABELA 35 - Médias das pressões de iniciação da ruptura e de injeção, obtidas no tratamento realizado no campo de prova na Usina de Rasgão.

TABELA 36 - Resultados do teste t (duas amostras em par) para os valores médios dos tempos de propagação das ondas $S$ antes e depois do tratamento do maciço, no campo de prova.

TABELA 37 - Resultados do teste t (duas amostras em par) para os valores médios dos tempos de propagação das ondas P, antes e após o tratamento do maciço, no campo de prova. 
LISTA DE ABREVIATURAS E SIGLAS

\author{
ABGE - Associação Brasileira de Geologia de Engenharia \\ ABNT - Associação Brasileira de Normas Técnicas \\ ASCE - American Society of Civil Engineers \\ CESP - Companhia Energética de São Paulo \\ ELETRONORTE - Centrais Elétricas do Norte do Brasil S.A. \\ ELETROPAULO - Eletricidade de São Paulo S.A. \\ EMAE - Empresa Metropolitana de Águas e Energia S.A. \\ IPT - Instituto de Pesquisas Tecnológicas do Estado de São Paulo S.A. \\ ISRM - International Society for Rocks Mechanics \\ PVC - Policloreto de vinila \\ RQD - Rock Quality Designation \\ SPT - Standard Penetration Test
}




\section{LISTA DE SÍMBOLOS}

A - no estudo hidráulico, é a área perpendicular ao sentido de escoamento do fluxo

D - diâmetro hidráulico

CV - coeficiente de variação

c/s + a - relação cimento/solo + água

E - módulo de Young

$e$ - abertura da fissura

F - estatística F

$\mathrm{F}_{2,8,10 \%}$ - valor tabelado de $\mathrm{F}$

F - field seismic fracture index

Fcrítico - valor estatístico tabelado

G - módulo de rigidez

$g$ - aceleração da gravidade

GL - grau de liberdade

$\mathrm{H}_{0}, \mathrm{H}_{01}$ e $\mathrm{H}_{02}$ - hipótese admitida nas análises estatísticas

$\mathrm{H}_{1}$ e $\mathrm{H}_{2}$ - hipótese alternativa nas análises estatísticas

i - gradiente hidráulico

K - módulo de compressibilidade

k - na estatística, é o tamanho da amostra 1

$k$ - coeficiente de permeabilidade

$\mathrm{L}_{\mathrm{i}}$ e $\mathrm{L}_{0}$ - comprimento

P - pressão hidrostática

p - no estudo hidráulico, é o perímetro ao longo do qual se estabelece o atrito

Pc - pressão de clacagem ou de propagação da fratura 
Pc1 e Pc2 - pressão de clacagem no primeiro e segundo ciclo, respectivamente

Pi - pressão de injeção

Pp - pressão de paralisação da injeção

Pr - pressão de ruptura

Pd - pressão de descompressão

Ondas P - ondas compressionais

Ondas S - ondas cisalhantes

$Q$ - vazão $(\ell / \mathrm{s})$

QM - quadrado médio

n - na estatística, é o tamanho da amostra 2

$\mathrm{R}$ - raio

$r$ - raio do furo

Rc - resistência à compressão simples de corpos-de-prova

$R e$ - número de Reynolds

$R e_{\mathrm{cr}}$ - número de Reynolds crítico

$R H$ - raio hidráulico

S - desvio padrão

S/A - relação de solo/água

SQ - soma dos quadrados

$\mathrm{s}_{\mathrm{R}}^{2}$ - quadrado médio do erro (QM erro)

Valor P - probabilidade

$V$ - no estudo hidráulico, é a velocidade da calda na fissura $(\ell / \mathrm{s})$

$V_{c r}$ - velocidade crítica

$V p$ - velocidade de propagação das ondas compressionais 
Vs - velocidade de propagação das ondas cisalhantes

$V m$ - velocidade da onda P na matriz

$V w$ - velocidade da onda P na água

$V f$ - velocidade da onda P no fluido

$V_{0}$ - velocidade da onda $\mathrm{S}$ na rocha sã à pressão igual à profundidade do maciço

$V_{g}$ - velocidade da onda S no material injetado

$v$ - velocidade cinemática do fluido

$\overline{\mathrm{x}}, \overline{\mathrm{x}}_{\mathrm{p}}, \overline{\mathrm{x}}_{\mathrm{s}}$ e $\overline{\mathrm{x}}_{\mathrm{t}}$ - média de uma amostra

$\overline{\mathrm{x}}_{1}$ - média da primeira amostra

$\overline{\mathrm{x}}_{2}$ - média da segunda amostra

$\alpha$ - nível de erro

$\sigma_{1}$ e $\sigma_{2}$ - tensão

$\mu$ - viscosidade absoluta

$\lambda$ - coeficiente de resistência ao fluxo

$\phi$ - porosidade

$\omega=$ porcentagem de injeção

$\delta$ - coeficiente de Poisson

$\rho$ - densidade do material

$\Delta$ - hipótese da diferença de média 


\section{RESUMO}

IYOMASA, W.S. Injeção de solo-cimento em solo residual de granitóide: uma proposta de análise com suporte estatístico e avaliação da eficiência com método geofísico. São Carlos, 2000. 221p. Tese (doutorado) - Escola de Engenharia de São Carlos, Universidade de São Paulo.

No presente trabalho são apresentadas sugestões de critérios executivos, fundamentados nos tratamentos efetuados em três obras brasileiras, em especial na Usina de Rasgão. O uso dos recursos da estatística também é proposto para avaliar a injeção de solo-cimento, ainda durante a fase executiva dos trabalhos. As análises realizadas mostram que as médias da pressão de iniciação da ruptura do maciço, em terreno natural, são crescentes com a profundidade. Observa-se também que à medida que o tratamento avança, os valores médios das pressões de ruptura e de injeção crescem nas linhas subseqüentes, tendendo a um valor constante com a profundidade e, conseqüentemente, indicando certa homogeneização do maciço. Destaca-se a performance do ensaio do tipo crosshole, executado ainda que em campo de prova, na avaliação da eficiência do tratamento. Nas paredes de uma trincheira escavada no campo de prova, observam-se fraturas hidráulicas predominantemente subverticais, algumas sub-horizontais e poucas inclinadas. Embora diferentes corantes tenham sido empregados nas caldas para observar as possíveis relações entre as fraturas hidráulicas, o processo de pigmentação adotado parece não ter sido adequado.

Palavras-chave: Injeção; Calda - solo-cimento; Tratamento; Consolidação 


\section{ABSTRACT}

IYOMASA, W.S. Soil-cement slurry grouting into the residual soil of granites: proposal continuous evaluation with statistics support and efficiency evaluation with geophysical methods. São Carlos, 2000. 221p. Tese (doutorado) Escola de Engenharia de São Carlos, Universidade de São Paulo.

Soil-cement slurry grouting has been applied for a long time, although not is commonly used in Brazil, a tropical country where thick layers of soil are frequently found. The present paper is based on the soil mass treatment carried out at three different sites, particularly at Rasgão Hydroelectric Power Plant. Statistics methods were applied in order to analyse the variation of the grouting pressures. They showed that pressure of fracturing were increasingly higher with depth in the natural soil mass. As long as the treatment goes on, it has also noticed that the average values of pressures fracturing and injection in each line of grouting became gradually higher, while the subsequent lines showed values of pressures tending to become constant with depth, suggesting a homogeneity of mechanical strength of the natural soil mass. Field geophysical tests performed before and after the grouting, using crosshole technique, succeeded in verifying the efficiency of the treatment. The excavation of a trench into the test site indicated that the hydraulic fracturing has developed greatly in a vertical position, other than horizontally. Although different colours of pigments were mixed into the slurry in order to investigate the possible relationship among hydraulic fractures, that procedure proved to be unsuccessful.

Keywords: Grouting; Soil-cement slurry; Treatment; Consolidation 


\section{INTRODUÇÃO}

Os primeiros estudos sobre caldas de solo-cimento foram realizados na França, em 1937, com a finalidade de aplicá-las na consolidação das margens de um canal, em Argen. No Brasil, apenas em 1969, essa técnica foi empregada para recuperar uma pequena extensão do pavimento rígido da Via Anchieta, na Serra do Mar - SP.

Em meados da década de 80 , as caldas de solo-cimento também foram empregadas na Barragem de Balbina (Rio Uatumã, AM) para obstruir canalículos (estruturas cilíndricas vazias de diâmetro variável) presentes na fundação da barragem. O tratamento foi conseguido, provocando-se fraturas hidráulicas no maciço terroso e preenchendo-as com calda de solo-cimento. Outra obra submetida ao tratamento com injeção de solo-cimento foi a Usina de Rasgão (Rio Tietê, SP), onde foi feita, entre 1986 e 1988, a consolidação das fundações das estruturas já existentes (casa de força, condutos forçados e tomada d’água da usina), bem como a redução da percolação de água pelo maciço terroso que sustenta a tomada d'água da usina, por meio de uma cortina de vedação.

Recentemente, em 1996, essa técnica de promover fraturas hidráulicas no maciço e preenchê-las com solo-cimento foi também aplicada nos trabalhos de consolidação das fundações dos edifícios da Cooperativa Central de Laticínios do Estado de São Paulo, situados em Guaratinguetá, SP. O maciço terroso das fundações das edificações existentes sofreu ataque das águas agressivas oriundas do processo industrial, tendo como conseqüências os abatimentos na superfície devido à lixiviação do solo e ao aparecimentos de inúmeras cavidades no interior do terreno. A reconstituição parcial da superfície do terreno e a obstrução dos vazios no maciço foi conseguida, empregando-se a técnica de injeção de calda de solo-cimento. 
Com efeito, verifica-se, atualmente, que a demanda por este tipo de tecnologia tende a aumentar, considerando-se o crescimento do número de construções de obras, principalmente barragens, em áreas onde a cobertura de solos apresenta espessuras consideráveis, como também a necessidade de se recuperar fundações de maciços terrosos que sustentam edificações antigas de pequeno a médio porte. Nestas condições, a injeção de solo-cimento pode vir a se constituir numa alternativa viável, técnica e economicamente, frente a outras soluções mais tradicionais, como o Jumbo Grouting e a injeção da calda de cimento.

Por esse motivo, diversos aspectos desta técnica merecem ser melhor investigados, desde os procedimentos para estabelecimento dos traços das caldas até a análise da eficiência dos tratamentos, quais sejam: reologia das caldas, interação argilacimento, resistência das caldas endurecidas, resistência à dissolução, procedimentos executivos, etc.

O principal objetivo da presente pesquisa foi contribuir para o estabelecimento de critérios e procedimentos executivos para aplicação de injeção de solo-cimento como técnica para consolidar e reduzir a percolação de água em maciços terrosos.

Para atingir esse objetivo, foram destacados os trabalhos executados na Usina de Rasgão, devido aos testes ali executados, e à grande quantidade de dados extraídos durante a campanha de injeção. As análises das pressões de iniciação da ruptura do maciço e de injeção foram realizadas com os recursos oferecidos pela estatística. Para executar os cálculos da estatística descritiva, da análise de variância, do teste de Scheffé, entre outros, foi empregado o programa de computador Microsoft Excel.

As principais hipóteses levantadas, pelo autor, sobre a técnica de injeção de solo-cimento e que orientaram o desenvolvimento dos estudos foram:

- há aumento gradativo das pressões de iniciação da ruptura do maciço e de injeção ao longo dos furos; 
- há acréscimos nos valores médios das pressões à medida que se avança nas etapas de trabalho;

- ao se confirmar a hipótese anterior, presumiu-se que a taxa de crescimento das pressões, obtida pela razão entre a primeira e a última etapa do trabalho de injeção, seria maior nas proximidades da superfície do terreno.

Outro objetivo do presente estudo foi sugerir o ensaio geofísico do tipo crosshole como complemento à tradicional técnica de medida do coeficiente de permeabilidade do maciço, utilizada para avaliar a eficiência da injeção. Para isso, um campo de prova foi construído junto da Usina de Rasgão, onde os trabalhos de levantamento geofísico e de injeção de solo-cimento foram executados em três etapas: ensaio geofísico em terreno natural; campanha de injeção no interior do campo de prova e ensaio geofísico após o tratamento do terreno.

Os resultados obtidos nesse campo de prova, principalmente das velocidades das ondas sísmicas (P e S) medidas antes e após a injeção, foram analisados e discutidos neste trabalho. 


\section{METODOLOGIA}

Para atingir os objetivos propostos neste estudo, a pesquisa foi realizada, obedecendo-se as seguintes etapas de trabalho:

1. Levantamento bibliográfico: a primeira etapa do trabalho de pesquisa constituiu na coleta de dados de dissertações, teses, artigos e publicações técnicas, nos quais são discutidos diversos aspectos do tratamento de maciços rochosos e terrosos, por meio de injeções de cimento e solo-cimento.

2. Coleta dos relatórios técnicos da obra de Rasgão: foi realizado, ainda, o levantamento no arquivo da obra de Rasgão para extrair todas as informações técnicas, desde a campanha de investigação geológico-geotécnica até os resultados finais dos ensaios realizados no campo e no laboratório, necessárias para a presente pesquisa.

3. Estudos de casos: nesta etapa do trabalho, procurou-se estudar e comparar as técnicas empregadas nos tratamentos de maciços terrosos por meio de injeção de solo-cimento executados nas obras de Balbina, Rasgão e Cooperativa Central de Laticínios.

4. Organização das informações: a partir do estabelecimento de uma diretriz de estudos, todas as informações coletadas, principalmente das pressões aplicadas para ruptura e injeção da calda de solo-cimento, foram organizadas em banco informatizado (Microsoft Access) para facilitar as análises estatísticas.

5. Tratamento, análise e interpretação dos dados: nesta etapa do trabalho, foram realizados tratamento e análise das informações, empregando-se como 
ferramenta os recursos disponíveis da estatística e da informática (softwares), com a finalidade de buscar o entendimento da técnica de injeção de solocimento, relativas às pressões aplicadas, no tratamento de maciço terroso para consolidação e redução da percolação de água. Para isso, as análises das variações das pressões de iniciação da ruptura do maciço e de injeção foram efetuadas em etapas, de acordo com as hipóteses levantadas no início da pesquisa. Também foram realizadas no presente estudos: a análise do comportamento da pressão aplicada durante o processo do fraturamento hidráulico do maciço e a avaliação do uso da técnica geofísica para verificar a eficiência do tratamento. Abaixo, destacam-se as principais etapas de desenvolvimento deste trabalho:

1.1. Comportamentos das pressões de iniciação da ruptura do maciço e de injeção nos diferentes trechos de profundidades no terreno: a primeira etapa da análise estatística consistiu em avaliar esses comportamentos, desconsiderando-se os aspectos geológicos do maciço. Na etapa seguinte, repetiu-se a análise, tomando-se como base a camada superior do solo residual, com a finalidade de se observar possíveis comportamentos diferenciados das pressões em relação ao primeiro estudo.

1.2. Verificação dos acréscimos nas pressões de iniciação da ruptura do maciço e de injeção, quando as atividades passaram para etapas subseqüentes do tratamento, ou seja, da primeira ordem para a segunda e desta para a terceira.

1.3. Fraturamento hidráulico: foi realizado também o estudo do comportamento da pressão de injeção, por meio da estatística, durante o processo do fraturamento hidráulico do maciço, que se promove momentos antes da introdução da calda no maciço. 
1.4. Avaliação estatística das pressões aplicadas nos trabalhos de consolidação da fundação da Usina de Rasgão.

1.5. Execução do ensaio geofísico do tipo crosshole em um campo de prova: esse ensaio foi realizado antes e depois da injeção de solo-cimento, para avaliar a eficiência da técnica no tratamento do maciço, em complemento aos métodos tradicionais que determinam o coeficiente de permeabilidade do terreno. 


\section{REVISÃO BIBLIOGRÁFICA}

\subsection{Histórico sobre injeções}

O emprego de calda de cimento para injeção nos tratamentos de estruturas civis foi idealizado pelo francês Charles Bérigny, em 1802, quando estava realizando reparos nas guias das comportas da eclusa do porto de Dieppe. Destaca-se que nessa obra, entre 1802 e 1809, foi utilizada a pozolana no processo de injeção.

Em 1826, foram descritas, em relatórios, as primeiras referências do processo de injeção de calda de cimento. Entretanto, detalhes desta técnica relativos à obra de Dieppe, foram publicados por BÉRIGNY apud GLOSSOP (1960), apenas em 1832.

O avanço significativo para aplicação da técnica de injeção de cimento foi promovido por Thomas Hawksley, em 1876, quando empregou, com critério, esta técnica para obturar as fissuras das rochas da fundação de uma barragem de terra (GLOSSOP, 1961). Entretanto, até meados deste século, as injeções foram executadas quase que exclusivamente em obras portuárias (GLOSSOP, 1960).

Esta técnica foi gradualmente desenvolvida até 1930, por meio de aplicações práticas em algumas obras (GLOSSOP, 1961) e, nessa época, o United States Bureau of Reclamation elaborou um estudo preliminar dos procedimentos adotados nos trabalhos das obras de barragens. Realizou também uma pesquisa das caldas de cimento, em laboratório, que, associada ao estudo anterior, permitiram estabelecer uma especificação técnica preliminar destinada à execução do tratamento das fundações das estruturas civis da Barragem de Hoover (GLOSSOP, 1961). 
Em 1933, LUGEON apud QUADROS (1982) estabeleceu os primeiros critérios executivos de ensaios de permeabilidade em maciço, tendo como objetivo o emprego da técnica de injeção de cimento para obturar fissuras e para avaliar a eficiência do tratamento, cujos princípios são utilizados até hoje nas obras de engenharia.

Entretanto, foi apenas em 1962 que um grupo de pesquisadores, pertencente à American Society of Civil Engineers, apresentou um documento contendo diretrizes para execução de injeção de calda de cimento. Além dos relatos de tratamentos efetuados com injeções de cimento, foram apresentadas neste documento as terminologias empregadas nos trabalhos, os critérios e métodos de injeção, os equipamentos e sua disposição ao longo do circuito, as sugestões de pressões de injeção, as técnicas de controle do processo e as propostas de projetos (ASCE, 1962).

A adição de argila na calda de cimento foi feita, em 1937, no trabalho para consolidação do maciço terroso das margens de um canal, em Argen (França), conforme descreveram BARBEDETE \& SABARLY (1981).

No Brasil, entre 1969 e 1970, foi utilizada calda de solo-cimento na recuperação de uma pequena extensão do pavimento rígido da Via Anchieta (PITTA, 1984). Ainda nesta época, BRITO \& DÉCOURT (1970) mencionaram que a vedação subterrânea nas fundações das barragens de Arroio Duro, Vacacaí-Mirim, Passo Fundo e Juqueri, estas duas últimas em construção naquele ano, foi obtida por meio de argamassa de solo-cimento. Mencionaram também o emprego desse tipo de argamassa para impermeabilizar provisoriamente o subsolo, com a finalidade de realizar escavações para construção do cut off da Barragem de Ponte Nova, localizada no Rio Tietê, SP.

BARBEDETE \& SABARLY (1981) realizaram estudos de caldas de solocimento utilizadas nas cortinas de vedação ou impermeabilização das laterais da Barragem de Bin el Quidane, em Marrocos, e propuseram uma representação gráfica dessas caldas. 
Outros autores, como DEERE (1982) e HOLANDA \& GUEDES (1981), também realizaram estudos para diferentes traços de caldas de solo-cimento, por meio de ensaios laboratoriais, com a finalidade de determinar a massa específica, a fluidez, a resistência mecânica e o fator de sedimentação.

Em meados da década de 80, na Barragem de Balbina, as caldas de solocimento foram utilizadas para obstruir canalículos (estruturas cilíndricas vazias de diâmetro variável) presentes na fundação do barramento (MELLO et al., 1987). O preenchimento dessas estruturas foi feito por meio do fraturamento hidráulico provocado pela injeção de caldas de solo-cimento, com o emprego das válvulas do tipo manchete (LE TIRANT \& GAY, 1972; BARRADAS, 1985; MELLO et al., 1988).

Na recuperação da Usina Hidrelétrica de Rasgão (BUDWEG et al., 1985), foi utilizada a técnica semelhante à empregada na Barragem de Balbina, porém com objetivo de consolidar e reduzir a percolação de água pelo maciço terroso que sustenta o conjunto casa de força, condutos forçados e tomada d'água da usina. O tratamento adotado resultou do estudo e da investigação realizada, indicando a existência de caminhos preferenciais de percolação de água pelo maciço de fundação da usina (MELLO et al., 1990 e PASTORE, 1998).

Em 1996, foi realizado o tratamento de consolidação do maciço de fundação das edificações da Unidade Industrial de Guaratinguetá da Cooperativa Central de Laticínios do Estado de São Paulo. De acordo com o laudo técnico, o solo sofreu ataque de águas agressivas oriundas do processo industrial, tendo causado alterações nas fundações das edificações, abatimentos na superfície e inclusive cavidades no interior do maciço (PROGECONSULT, 1997). O tratamento adotado foi a injeção de solo-cimento por meio de tubos de PVC (policloreto de vinila) com válvulas do tipo manchete, cuja técnica aplicada é muito semelhante ao processo empregado nas fundações das barragens de Balbina e Rasgão. 
REED \& DUSSEAULT (1997) realizaram investigações sobre fraturamento hidráulico em solos não coesivos, através de testes realizados em laboratório, que consistiram na injeção de um gel viscoso em uma caixa contendo areia fina para provocar rupturas hidráulicas. Dois destes testes geraram fraturas hidráulicas verticais e um terceiro produziu duas fraturas: uma vertical e a outra horizontal. Nos dois primeiros testes, os autores verificaram que as fraturas verticais apresentavam altura da ordem de $20 \mathrm{~cm}$, comprimento em torno de $15 \mathrm{~cm}$ e espessura do gel entre 2 e $3 \mathrm{~mm}$. No terceiro, a fratura horizontal apresentou comprimento de $32 \mathrm{~cm}$ e largura de $47 \mathrm{~cm}$, enquanto que as medidas obtidas na fratura vertical foram de $40 \mathrm{~cm}$ e $9 \mathrm{~cm}$, respectivamente, no comprimento e na altura.

REED \& DUSSEAULT (1997) realizaram, também, ensaios em dois campos de provas com características geológicas diferentes, localizados na Universidade de Waterloo, no Canadá. No primeiro, cujo terreno era constituído por argila siltosa, injetaram lama com areia grossa e, no segundo, composto por cascalho arenoso, os autores resolveram injetar o mesmo gel viscoso utilizado no laboratório. Neste segundo local, devido às características geológicas do terreno, não foram observadas ocorrências de fraturamento hidráulico.

Após a conclusão dos testes, verificaram que, além do fraturamento hidráulico, ocorreram outros quatro processos durante a injeção da lama ou do gel: erosivo do tipo piping, infiltração do fluido no maciço, desmoronamentos e formação de dutos pela expulsão dos sedimentos.

Ao concluírem os estudos, os autores afirmaram que, para obter as fraturas hidráulicas nos maciços, foi necessário, de certa maneira, controlar a ocorrência dos outros processos indesejáveis, através do ajuste da viscosidade do fluido a ser injetado, da estratégia no método executivo e da perfuração adequada.

Ainda com objetivo de melhorar as condições geológico-geotécnicas dos maciços, nas últimas décadas, foram desenvolvidas novas tecnologias e produtos químicos 
para uso nos tratamentos. Um exemplo desse avanço tecnológico foi a aplicação da injeção de poliuretano para impermeabilizar e consolidar a região do lake piercing do túnel de descarga da Barragem de Pirapora (IYOMASA et al., 1997). Trata-se de substância sintética (poliuretano) que resulta da reação de polimerização a partir de dois componentes básicos (poliol e isocianato), com adição eventual de um catalisador. Após a mistura das partes básicas, que é feita na bomba injetora desenvolvida especificamente para aplicação dessa técnica, o produto resultante reage com a água (agente expansível) presente nas fraturas da rocha, tendo como conseqüência o aumento do volume do produto injetado.

Informações das características técnicas dos produtos químicos (silicatos, polímeros, acrílicos, entre outros) utilizados nos tratamentos por injeção, assim como a respeito dos equipamentos necessários e das técnicas empregadas, podem ser obtidas em KAROL (1982); HOSHIYA et al. (1982); BERRY (1982); BAKER (1982); CLARKE (1982); BURLAND \& MICHELL (1989).

Recentemente, foi desenvolvida uma nova técnica para tratamento de maciços rochosos decompostos e pouco permeáveis. Trata-se do método denominado Dry Grouting, que consiste em realizar injeção de cimento por meio de ar comprimido, cuja capacidade de penetração é de 10 a 100 vezes maior do que a água (TAKEBAYASHI et al., 1996 e FUJISAWA, et al., 1996).

Antes da introdução do cimento em pó, os autores injetaram ar comprimido com a finalidade de secar o trecho do furo, bem como realizar uma avaliação do maciço quanto à permeabilidade e velocidade do fluxo de ar. Durante o teste para determinação da pressão de injeção, os autores verificaram, também, eventuais recalques no maciço. Encerrada a etapa de avaliação, foi procedida a injeção do pó de cimento empregando-se ar comprimido com baixa pressão (MATSUMOTO et al., 1996). Para esse tipo de serviço, os autores fizeram o acompanhamento técnico para o controle do fluxo de ar e da pressão na "boca" do furo para evitar eventuais soerguimentos e recalques (RIBEIRO, 1997). 
Os autores deste método afirmam que são grandes as vantagens do novo processo em relação à técnica tradicional, que utiliza a água como condutor do cimento. Para comprovar a afirmação, foram apresentados os resultados de tratamentos executados com ar comprimido que, devido à sua alta capacidade de penetração, permitiram introduzir o cimento nas fissuras pouco permeáveis. Outras vantagens apontadas pelos autores foram: rapidez do tratamento e a desobrigação em construir reservatório e rede de água para injeção. Entretanto, MATSUMOTO et al. (1996), ao executarem o tratamento de um maciço rochoso alterado, pelo novo método, encontraram grandes dificuldades para injetar fraturas preenchidas com alta quantidade de silte, argila e água.

\subsection{Equipamentos}

Para executar a injeção de calda através de furos nos maciços, necessita-se de dois grupos distintos de equipamentos: o primeiro é composto pelas máquinas e acessórios de perfuração, enquanto que o segundo, pelas de injeção.

Em geral, as perfurações das campanhas de injeção, devido ao baixo custo, são realizadas com equipamentos rotopercussivos pneumáticos. Para acionar tais equipamentos, necessita-se, portanto, de compressor de ar que é movido por um motor a combustão ou elétrico. Nos trabalhos de grandes dimensões, o compressor é substituído por uma central de ar comprimido que alimenta as perfuratrizes através de rede de tubulações. Existem diversos tipos de perfuratrizes com diferentes capacidades de perfuração, para uso em terreno livre ou em galerias.

O grupo dos equipamentos de perfuração possui, ainda, uma bomba d’água para permitir a circulação do líquido pela composição de perfuração, removendo os detritos do interior do furo, além de evitar o aquecimento elevado na ferramenta de corte (SAMPAIO, 1988). 
A FIGURA 1 exibe dois tipos de perfuratrizes rotopercussivas, constituídas por chassi, conjunto de comando, torre e rotor. As perfuratrizes apresentadas possuem pneus para facilitar a locomoção, porém existem outras apropriadas para fixação em plataformas. Existem também outras que possuem sistema próprio de locomoção. Os acessórios que acompanham as perfuratrizes são: hastes e conexões, brocas de perfuração ou bits, revestimentos metálicos telescopáveis para estabilizar as paredes dos furos (SERRA JÚNIOR, 1991).

O segundo grupo de equipamentos, destinado à injeção, é composto por um misturador e agitador de caldas, bomba injetora, além dos acessórios constituídos por: hastes, tubulações flexíveis, obturador e tubo de PVC com válvula-manchete.

O misturador é um recipiente cilíndrico, com capacidade de até 500 litros, no qual se realiza a mistura dos componentes da calda com a água. A mistura mecânica é feita por meio de pás helicoidais que giram em alta rotação. Alguns misturadores possuem, ainda, uma bomba para circular a calda na vertical. O agitador assemelha-se ao misturador, porém as pás helicoidais são rotacionadas em baixa velocidade para evitar que ocorra a sedimentação das partículas sólidas, preservando a característica reológica das caldas.

A válvula-manchete é um dispositivo de borracha, instalada no tubo de PVC, que tem a função de evitar que a calda injetada no maciço retorne para o interior da tubulação. A válvula permite, ainda, complementar as injeções sem a necessidade de abrir novos furos no maciço, tornando possível a execução de várias fases de injeção, no mesmo ponto do maciço. A FIGURA 2 exibe os componentes da válvula e a FIGURA 3, o tubo de PVC com a válvula.

Para fixar o tubo de PVC no interior do furo, é necessário preencher o espaço anelar com caldas, denominadas bainha de cimento ou solo-cimento. Após sua fixação, a injeção é conseguida aplicando-se pressões crescentes no interior do tubo, através de um obturador de anel (FIGURA 4) que se abre após a ruptura da bainha. 


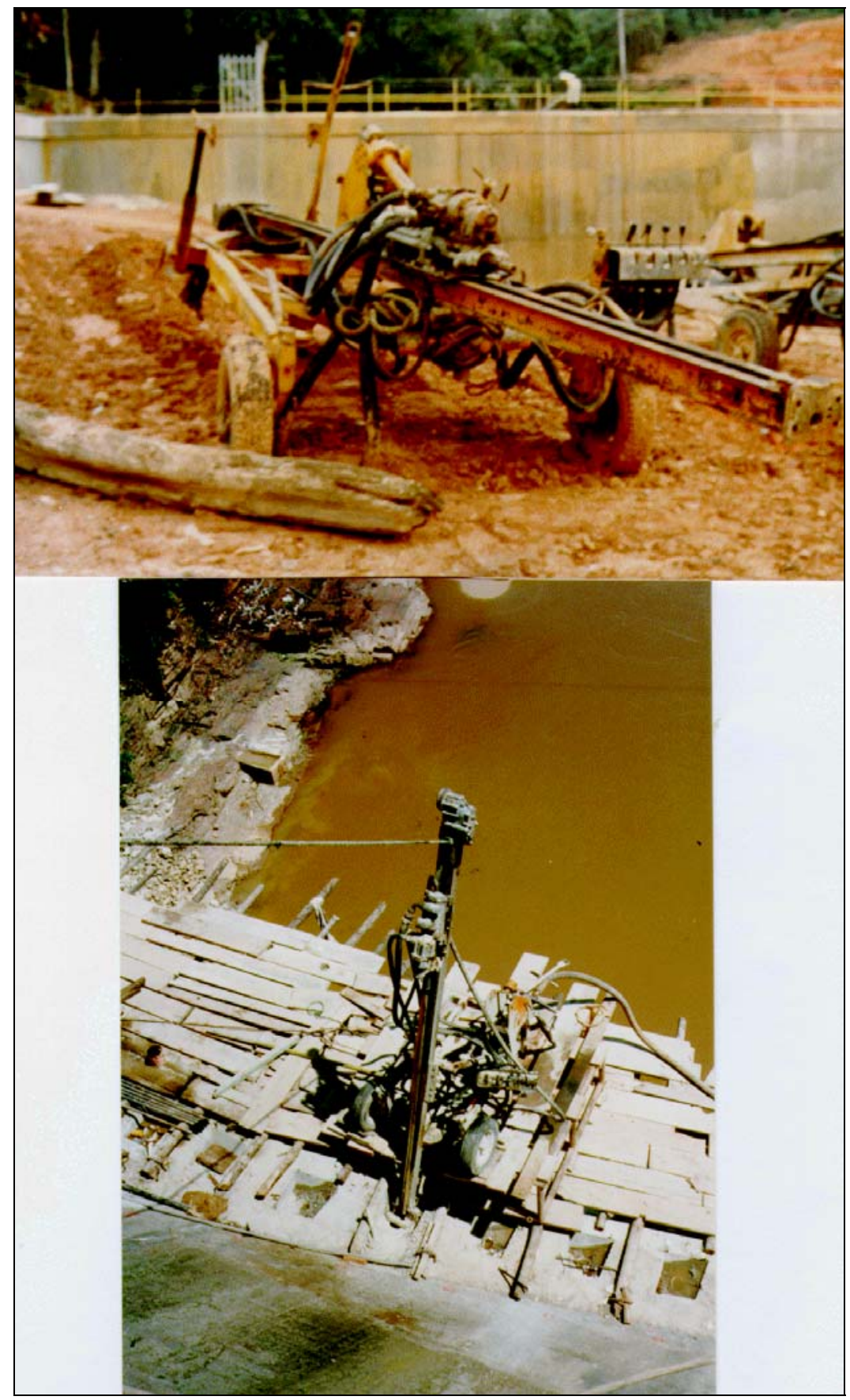

FIGURA 1 - Equipamentos de perfuração movidos a ar comprimido (rotopercussiva), com pneus para locomoção. 


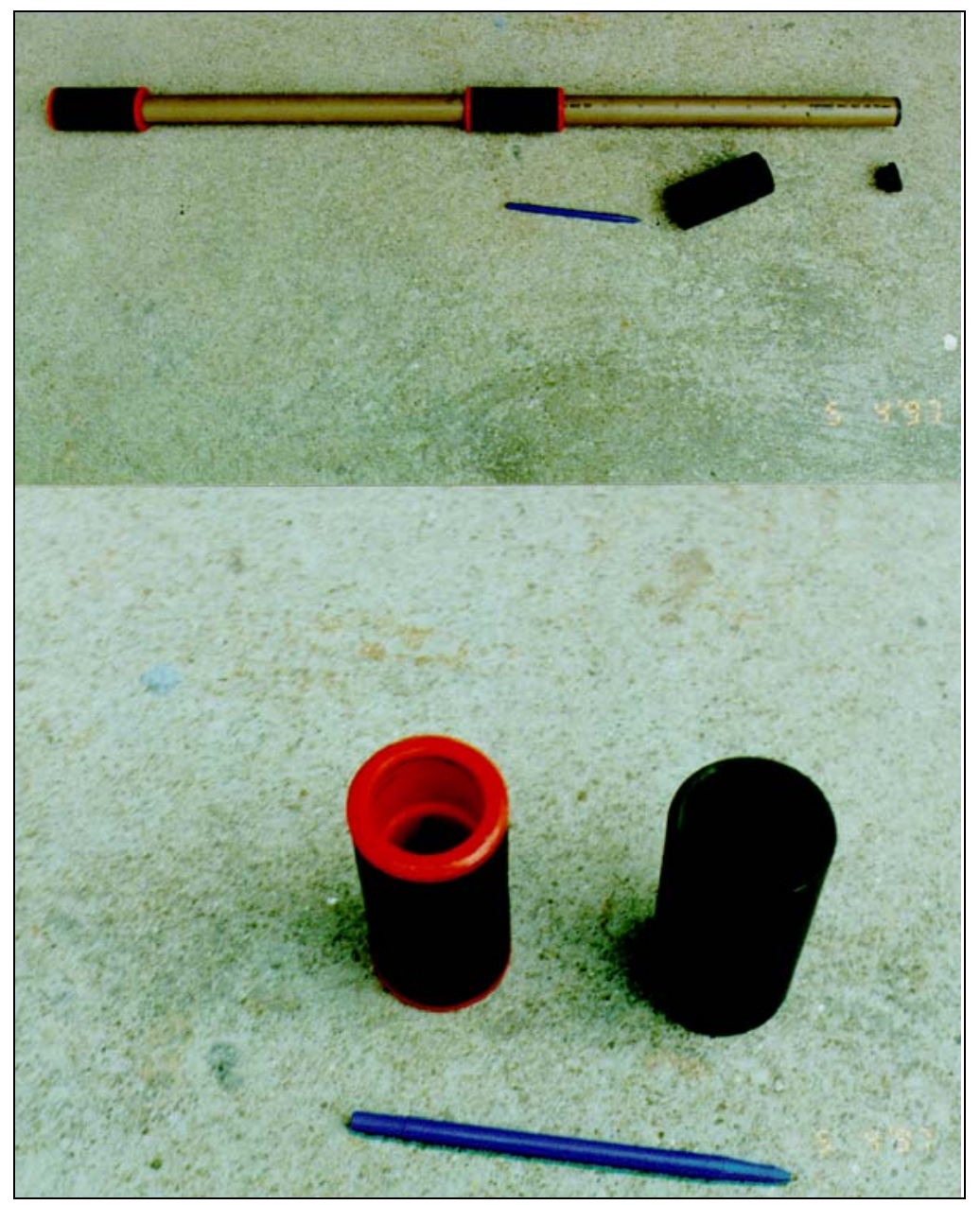

FIGURA 2 - Válvula-manchete. A peça do lado esquerdo é uma válvula moderna composta por um cilindro de borracha e um dispositivo (vermelho) com encaixe para o tubo de PVC. A peça da direita é apenas um cilindro de borracha que compõe a válvula.

O obturador é constituído por um tubo metálico, cuja parte interna (câmara) possui perfurações laterais para permitir a passagem da calda, e nas duas extremidades existem anéis duplos de borracha para vedar a passagem da calda entre o obturador e o PVC. Essa vedação é conseguida através do ligeiro deslocamento dos anéis quando a câmara é submetida a uma pressão.

No trabalho apresentado por GOURLAY \& CARSON (1982) podem ser encontrados outros equipamentos utilizados nas injeções, bem como verificada a disposição de cada dispositivo ao longo do circuito de injeção. 


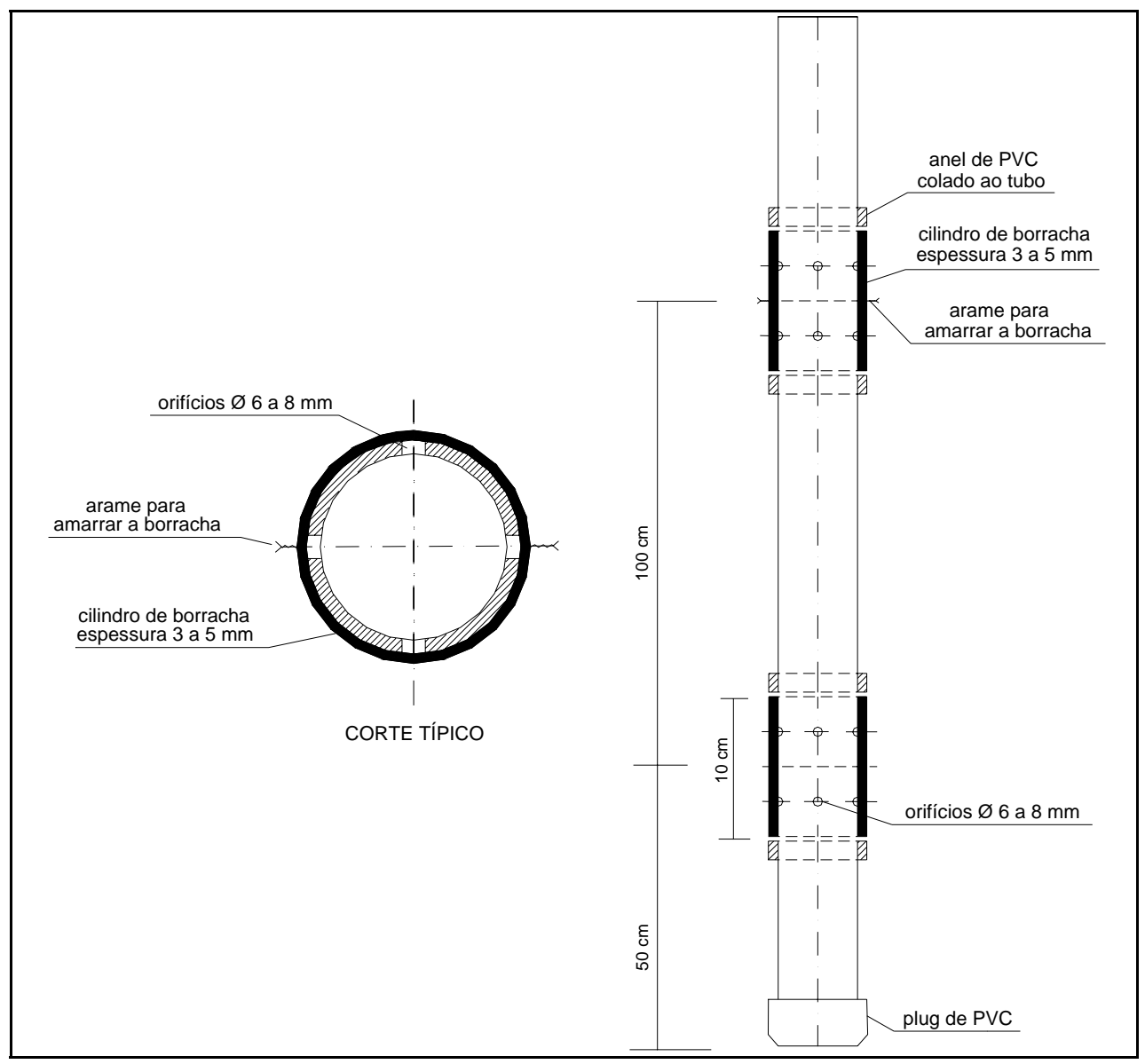

FIGURA 3 - Disposição esquemática dos componentes necessários para montagem do tubo de PVC com válvula-manchete. Os anéis localizados nas extremidades do cilindro de borracha são fixos no tubo de PVC ( $\phi=11 / 2$ ") e servem para evitar possíveis movimentações da válvula, durante a injeção. $\mathrm{O}$ arame para fixação é um segundo dispositivo para evitar esse movimento. Os orifícios no tubo PVC são as saídas da calda de injeção. 


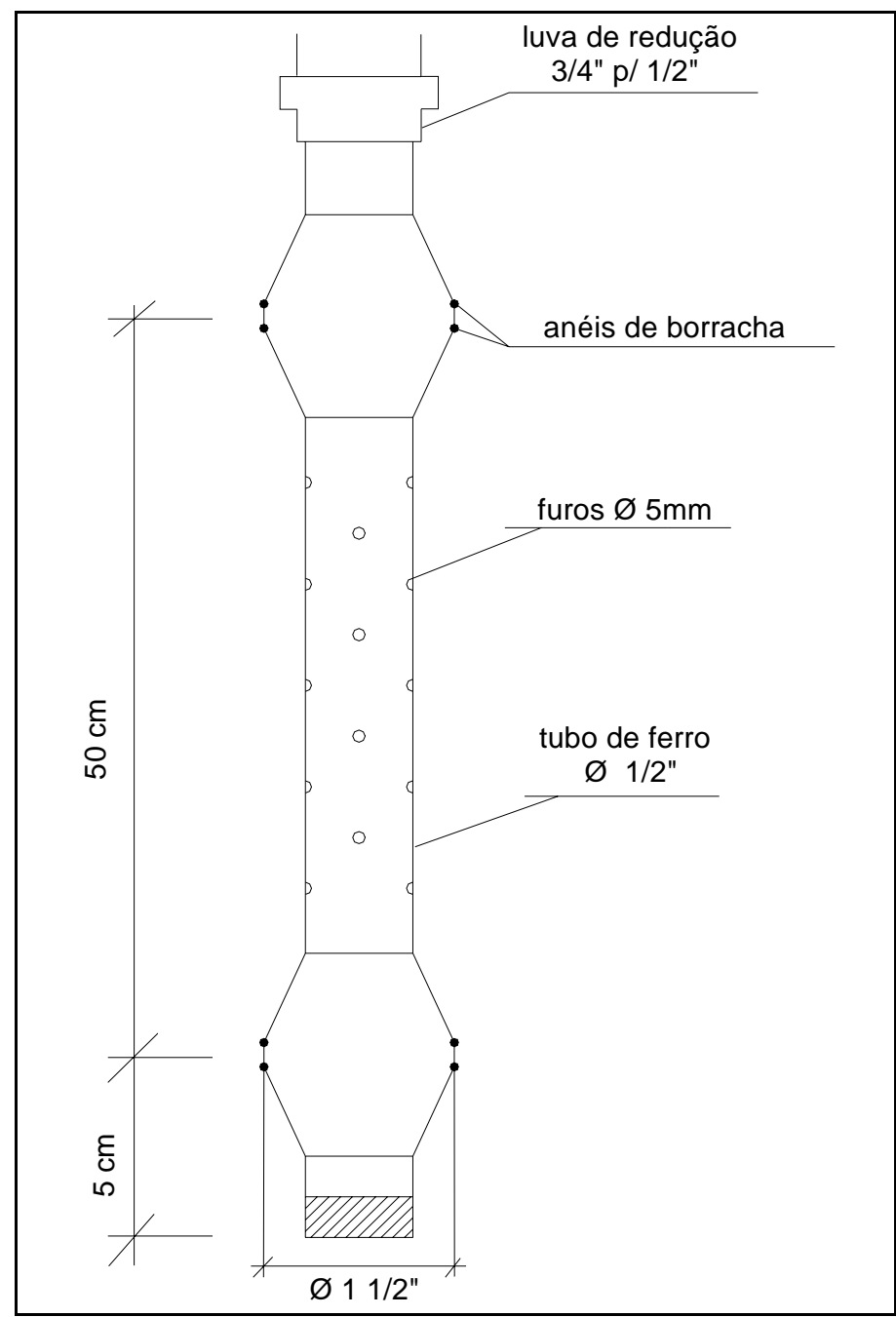

FIGURA 4 - Obturador de anel utilizado em injeções com válvula-manchete. Os furos no obturador são saídas da calda. Os anéis duplos de borracha (superior e inferior) se ajustam na parede interna do tubo de PVC com válvulasmanchete e formam uma câmara hermética, quando é aplicada uma certa pressão.

\subsection{Propagação de fraturas induzidas por fraturamento hidráulico}

A melhoria das condições geológico-geotécnicas dos maciços terrosos, por meio de injeção com válvulas-manchete, pode ser obtida desde que se promova, inicialmente, a ruptura do terreno, através de processos hidráulicos, para permitir a introdução de calda de solo-cimento ou apenas de cimento. 
Para o entendimento do processo de fraturamento hidráulico de maciços terrosos recorreu-se aos primeiros estudos realizados em maciços rochosos. A técnica do fraturamento hidráulico em maciços rochosos vem sendo empregada há algumas décadas, principalmente na exploração petrolífera para estimular a produção dos poços. Assim, HUBBERT \& WILLIS (1957) realizaram estudos teóricos e experimentais em corpos-deprova de gelatina, na condição não drenada, ou seja, sem a ocorrência de fluxo do fluido na fratura durante o processo de fraturamento. Verificaram que a fratura induzida tende a se apresentar perpendicularmente à direção da tensão principal menor (FIGURA 5).

É importante ressaltar que o fraturamento hidráulico em maciços, provocado por esforços de tração, se diferencia das rupturas por cisalhamento que são obtidas pela aplicação de esforços cisalhantes.

HUBBERT \& WILLIS (op. cit.) estudaram, ainda, a influência do furo de sondagem em um meio saturado homogêneo, isotrópico e elástico, pois admitiam que a perfuração geraria uma concentração de tensões na região periférica do orifício. Ao final dos estudos, concluíram que a região sob esta influência situa-se a uma distância de até 6 vezes o raio do furo.

Utilizando os resultados alcançados na pesquisa básica realizada por HUBBERT \& WILLIS (op.cit.), dez anos mais tarde, HAIMSON \& FAIRHURST (1967) realizaram também um estudo teórico sobre fraturamento hidráulico e demonstraram que, empregando cálculos matemáticos, o excesso de pressão no furo não gerava acréscimos de pressão neutra no meio, contrariamente ao que se conjeturava até aquela ocasião. Os autores verificaram, também, que esta pressão não se alterava devido ao furo de sondagem.

Nesta mesma época, BARON et al. (1967) também realizaram ensaios em laboratório e experimentos de campo que permitiram elaborar estudos teóricos sobre fraturamento hidráulico em maciços rochosos. 


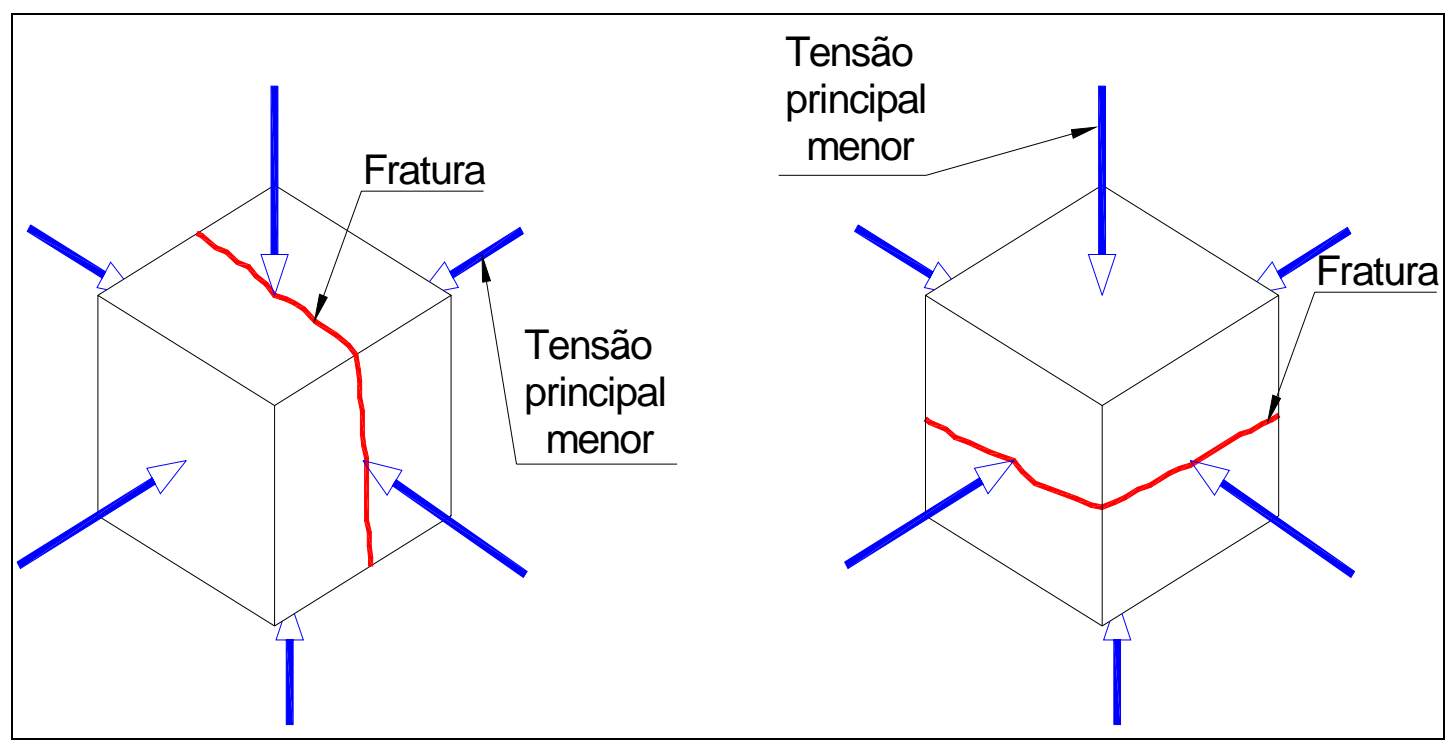

FIGURA 5 - Mecanismo de fraturamento hidráulico obtido em corpos de prova (HUBBERT \& WILLIS, 1957).

Ainda para a condição não drenada, KENNARD, em 1970 (apud BARRADAS, 1985), realizou ensaios de infiltração em maciços terrosos e fez ainda a análise teórica sobre a iniciação do fraturamento. Observou dois tipos de mecanismo: a expansão do maciço e o seu fraturamento. Este autor verificou que havia expansão do maciço terroso quando a pressão neutra no solo atinge um determinado valor de excesso de pressão. Nos ensaios em piezômetros, observou que, no trecho sob pressão, o maciço mostrou tendência em afastar-se do tubo (piezômetro) e o espaço anelar foi ocupado pelo fluido injetado, no caso deste experimento, a água. Entretanto, quando o excesso da pressão neutra aplicada transmite tensões adicionais ao meio, podem ocorrer fraturas verticais ou horizontais no maciço, respectivamente, quando a tensão efetiva tangencial ou vertical se anulam. Estudos de fraturamento hidráulico em ensaios de permeabilidade de campo também foram realizados por BJERRUM et al. (1972).

Em condições drenadas, ou seja, com movimento do fluido para o meio durante o fraturamento, HAIMSON \& FAIRHURST (1967) admitiram tensões geradas pelo fluxo do fluido injetado no furo. Para estas condições, os autores desenvolveram análise do 
fraturamento vertical no maciço. Posteriormente, BARRADAS (1985) utilizou os mesmos dados e realizou estudo do desenvolvimento das fraturas horizontais.

JAEGER, em 1962 (apud BARRADAS, 1985), realizou estudo em meio saturado homogêneo, isotrópico e elástico linear e com um plano de fraqueza, simulando a ocorrência de uma fratura ou plano de orientação natural da rocha. Fundamentado nos critérios de ruptura de Mohr-Coulomb, o autor concluiu que havia possibilidade da fratura ser induzida pelo plano de fraqueza, onde a resistência ao cisalhamento era bem menor.

Em geral, os estudos sobre fraturamento hidráulico procuram relacionar as pressões de ruptura aplicadas nos furos de sondagens com as características geomecânicas da rocha. Para melhor entendimento desse assunto, CAMPONUOVO et al. (1980) produziram estudos experimentais de fraturamento hidráulico em modelos de laboratório. A finalidade principal foi visualizar o desenvolvimento das fraturas durante a sua propagação, bem como a determinação dos valores numéricos destes parâmetros.

Ainda nessa década, com objetivo de compreender melhor as tensões atuantes no maciço, HAIMSON (1980) realizou estudo para determiná-las por meio do fraturamento hidráulico numa escavação subterrânea, destinada ao armazenamento de água, em rocha quartzítica. Os testes foram executados em profundidades que variaram de 2 a $240 \mathrm{~m}$, com emprego de obturadores de $1 \mathrm{~m}$ de comprimento. Os resultados mostraram que a tensão horizontal principal era maior que a vertical em trechos profundos dos furos. Verificaram, também, que acima de $20 \mathrm{~m}$ o regime de tensões foi substancialmente diferente da região abaixo de $30 \mathrm{~m}$. O autor verificou também que na superfície, ou próximo dela, os valores medidos da tensão por meio do ensaio são incompatíveis com as tensões tectônicas.

Tais observações devem ser consideradas nos tratamentos dos maciços por fraturamento hidráulico (algumas vezes denominado “clacagem”) em geologia de engenharia, pois, em geral, os trabalhos situam-se nesta região superficial do terreno. 
Nas investigações em geologia de engenharia, principalmente em obras subterrâneas, empregam-se ensaios de fraturamento hidráulico com o objetivo de medir o estado de tensões in situ, utilizando-se furos de sondagens mecânicas (ISRM, 1987).

O teste consiste em medir as magnitudes e direções das tensões máximas e mínimas num plano perpendicular a um furo vertical, executado a partir da superfície do terreno (FIGURA 6). Após a perfuração, insere-se uma composição de hastes com obturadores duplos, instalando-os em um trecho do maciço rochoso para permitir que se aplique pressão com a finalidade de provocar o fraturamento hidráulico na rocha. A ruptura é provocada por meio de injeção de água sob pressão, cujo valor é máximo no momento do fraturamento. Em seguida, a pressão decresce para posteriormente elevar-se e propagar a primeira ruptura. Em geral, são realizados três ciclos para determinação dos parâmetros necessários. Empregando-se fórmulas matemáticas, que têm como parâmetros os valores das pressões determinadas e a resistência da rocha, obtêm-se os valores das tensões máximas e mínimas. As direções são obtidas por meio de televisionamento ou obturadores de impressão, como empregado por HARPER \& HINDS (1978).

No Brasil, foi desenvolvido um obturador de impressão constituído por borracha elástico-plástica para extrair as orientações das estruturas geológicas, em furos de sondagens (CORRÊA FILHO \& QUADROS, 1987). Esse equipamento foi utilizado nos trabalhos de investigação para determinar o tensor de permeabilidade do maciço rochoso.

FRANCO \& SANTOS (1994) apresentaram resultados de ensaios de fraturamento hidráulico, realizados na área das estruturas subterrâneas da Barragem Serra da Mesa, que tiveram como objetivo a medida do tensor de tensões virgens do maciço granítico. A região é constituída por rocha granítica de alta qualidade geomecânica, circundada por micaxistos, quartzitos e gnaisses. As investigações mecânicas preliminares já mostravam que se tratava de maciço de boa qualidade, constituído por rocha, praticamente intacta e com valores altos de recuperação e RQD (Rock Quality Designation). 
Um dos motivos que levaram os projetistas a medir o tensor foi o arranjo das cavidades subterrâneas para o circuito hidráulico da usina, situadas cerca de 100 m de profundidade e altura das escavações de até $65 \mathrm{~m}$.

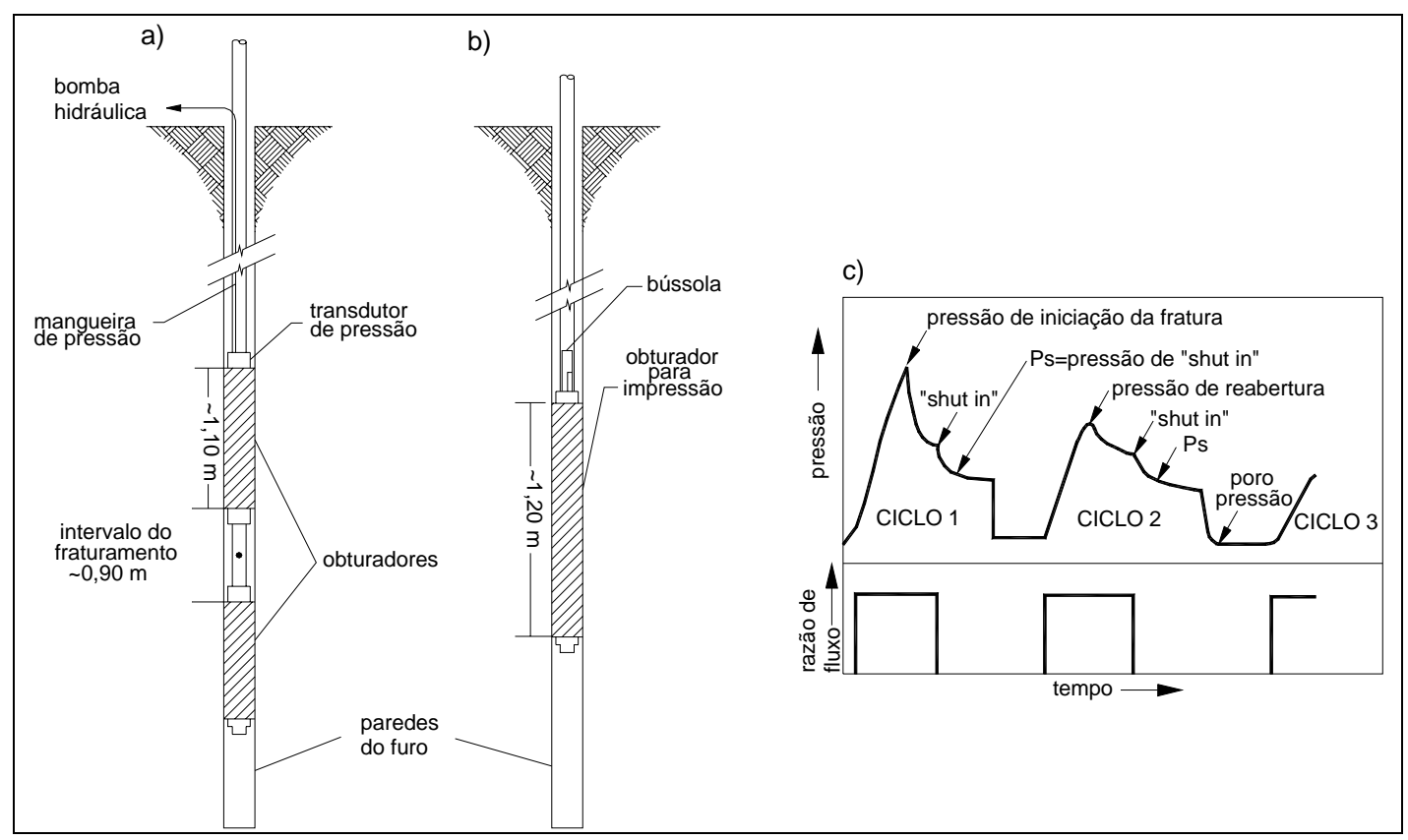

FIGURA 6 - Representação esquemática do fraturamento hidráulico (a) e da obtenção da impressão da fratura (b) (ISRM, 1987).

Foram realizados 20 ensaios de fraturamento hidráulico em dois furos distanciados de mais de $100 \mathrm{~m}$, adotando-se os critérios sugeridos pelo ISRM (1987). A partir dos resultados obtidos, os autores realizaram análise crítica com as técnicas estatísticas de interpretação e verificaram que a mecânica de formação da fratura ainda carece de uma pesquisa detalhada, confirmando as evidências apontadas em alguns trabalhos publicados nos últimos eventos relacionados aos estudos de fraturamento hidráulico.

Empregando as sugestões contidas no ISRM (1987), GAUSEREIDE et al. (1990) realizaram ensaios de fraturamento hidráulico no maciço rochoso, no qual estava prevista a escavação de um túnel (Projeto Afalfal - Chile), em furos de sondagens rotopercussivas horizontais. A decisão em realizar tais ensaios no maciço, constituído por 
rochas andesíticas, vulcânicas e intrusivas granodioríticas, foi tomada devido à necessidade em diminuir o trecho revestido com concreto para abreviar o tempo de execução da obra.

Os ensaios de fraturamento hidráulico foram realizados, aplicando-se pressões crescentes, com incremento de $0,5 \mathrm{kgf} / \mathrm{cm}^{2}$, por meio de lama bentonítica para evitar a penetração do fluido na fratura. De acordo com os autores, os resultados alcançados situaram-se próximos daqueles estimados no projeto, principalmente nas regiões onde o maciço encontrava-se muito fraturado. Afirmaram, ainda, que a interpretação dos resultados ficou prejudicada devido ao comportamento plástico do maciço e, nestes trechos do maciço rochoso, decidiram adotar valores conservadores para o projeto.

Como pôde ser visto, os estudos de fraturamento hidráulico em maciço rochoso buscam informações técnicas diferentes daquelas que se procuram nos ensaios realizados em maciços terrosos, embora as técnicas aplicadas tenham grande semelhança. Enquanto os ensaios em maciços rochosos visam à obtenção do estado de tensão, nos maciços terrosos procura-se compreender a forma de ocorrência das fraturas.

BARRADAS (1985) efetuou análise da iniciação e propagação das fraturas induzidas por injeções em maciço terroso para tratamento da fundação da barragem de terra de Balbina. Para isso, foi necessário abordar os estudos teóricos sobre a propagação do fraturamento hidráulico em maciços rochosos.

As teorias que analisam a propagação das fraturas induzidas nesses maciços (HOWARD \& FAST, 1970) são divididas basicamente em duas linhas de pesquisa, a saber: a primeira admite a penetração do fluido pela parede das fraturas no momento da ruptura (drenada), e a segunda não considera essa penetração (não-drenada). Os estudos relacionados com a primeira linha de pesquisa desconsideram as características geomecânicas do meio, ao contrário da segunda. Existe um terceiro grupo de pesquisadores que admite a condição de fluido penetrante e as condições geomecânicas do meio. 
Com efeito, todos os estudos teóricos já realizados admitiram as seguintes hipóteses: meio homogêneo, isotrópico e elástico linear; fluido injetado com características de um líquido muito viscoso; fluxo em regime laminar; efeitos gravitacionais desprezados; e raio do furo descartado em função do raio da fratura.

Também sob estas condições, BARRADAS (1985) analisou os trabalhos dividindo-os em dois grupos: com fluido drenado e não-drenado. Indiferentemente das várias condições de análise nos estudos, o autor verificou apenas as propagações das fraturas verticais e horizontais.

No tratamento da fundação da barragem de terra de Balbina, foi utilizada a técnica do fraturamento hidráulico para interceptar cavidades tubulares, denominadas canalículos, presentes no solo residual de vulcanitos que exibiam valores do coeficiente de permeabilidade relativamente altos $\left(10^{-3} \mathrm{~cm} / \mathrm{s}\right)$, de acordo com MOREIRA et al. (1990). Entretanto, JURY (1989) atribuiu valores superiores de permeabilidade, com coeficientes de $10^{-1}$ a $10^{-2} \mathrm{~cm} / \mathrm{s}$, principalmente até a profundidade de $6 \mathrm{~m}$, onde foi observada a ocorrência, com maior incidência, de canalículos que caracterizam os solos da região amazônica. Tais valores foram obtidos em ensaios de bombeamento e recuperação em poços.

Aplicando as soluções teóricas existentes sobre fraturamento hidráulico nos estudos do tratamento efetuado na fundação dessa barragem, BARRADAS (op.cit.) concluiu que "a série de suposições feitas no decorrer do trabalho pode ter feito com que o comportamento do modelo idealizado se afastasse sobremaneira do comportamento real”. Porém, ponderou e afirmou que "todas as hipóteses simplificadoras adotadas foram necessárias para que o mecanismo de fraturamento hidráulico pudesse ser compreendido, desde o início do processo até a propagação da fratura induzida". Ao final do estudo, o autor concluiu que as estimativas teóricas relativas às aberturas das fraturas induzidas situaram-se próximas aos valores medidos nas trincheiras de inspeção. 
Destacam-se, a seguir, alguns estudos teóricos sobre a geometria das fraturas hidráulicas induzidas. Sobre esse assunto, BARENBLATT (1962) efetuou estudos detalhados a respeito da forma da extremidade das fraturas induzidas. Ao empregar a Teoria da Elasticidade, mostrou que ela era arredondada (FIGURA 7a); porém, ao desenvolver seus estudos, admitindo-se que as tensões de tração são finitas na extremidade da fratura sob uma carga aplicada, verificou que a forma da seção transversal apresentava um ponto de reversão na extremidade da fratura (FIGURA 7b).

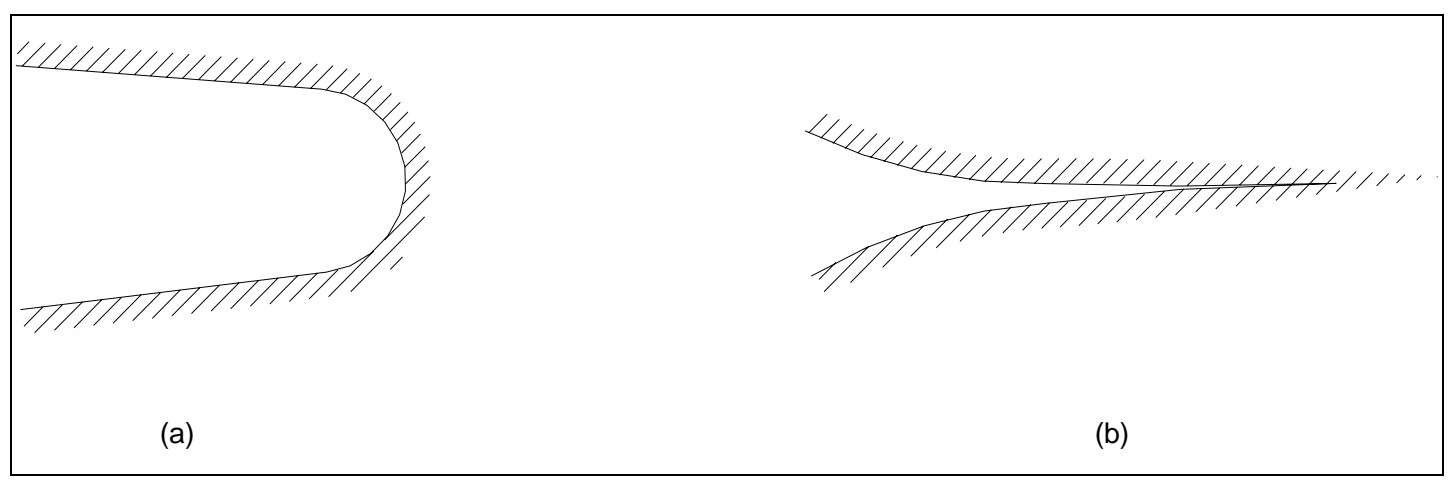

FIGURA 7 - Forma da extremidade da fratura induzida: (a) segundo a Teoria da Elasticidade e (b) segundo BARENBLATT (1962).

A forma da extremidade das fraturas hidráulicas também foi estudada por HAYASHI \& SAKURAY (1989), em modelos matemáticos simplificados. Para o estudo, os autores admitiram uma cavidade cilíndrica, de raio igual a $\mathrm{R}$, que foi submetida a um campo hidrostático (P) e a tensões $\sigma_{1}$ e $\sigma_{2}$ (FIGURA 8). Verificaram que a pressão neutra, ao longo da fratura, ia decrescendo em direção à extremidade até no momento anterior à propagação espontânea. Imediatamente após a propagação da fratura, a pressão sofreu uma queda rápida e mantendo-se constante ao longo da fratura (FIGURA 9). 


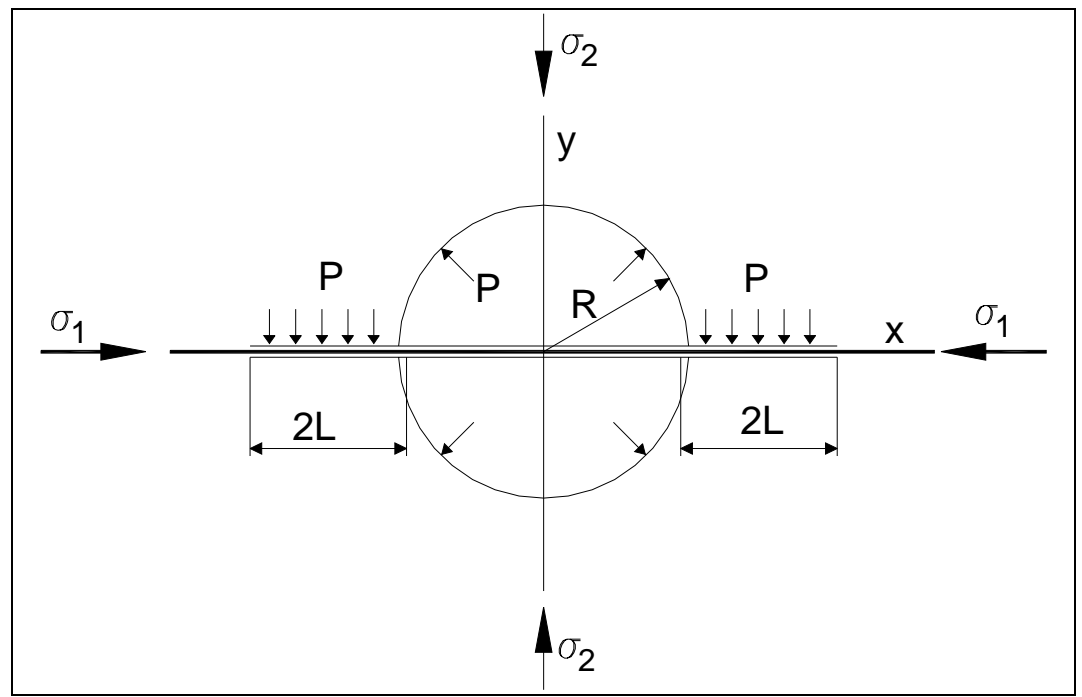

FIGURA 8 - Corte transversal de uma cavidade cilíndrica de raio igual a $\mathrm{R}$, fraturas com comprimento $2 \mathrm{~L}$, submetida a pressão hidrostática (P) e tensões $\sigma_{1}$ e $\sigma_{2}$ (HAYASHI \& SAKURAY, 1989).

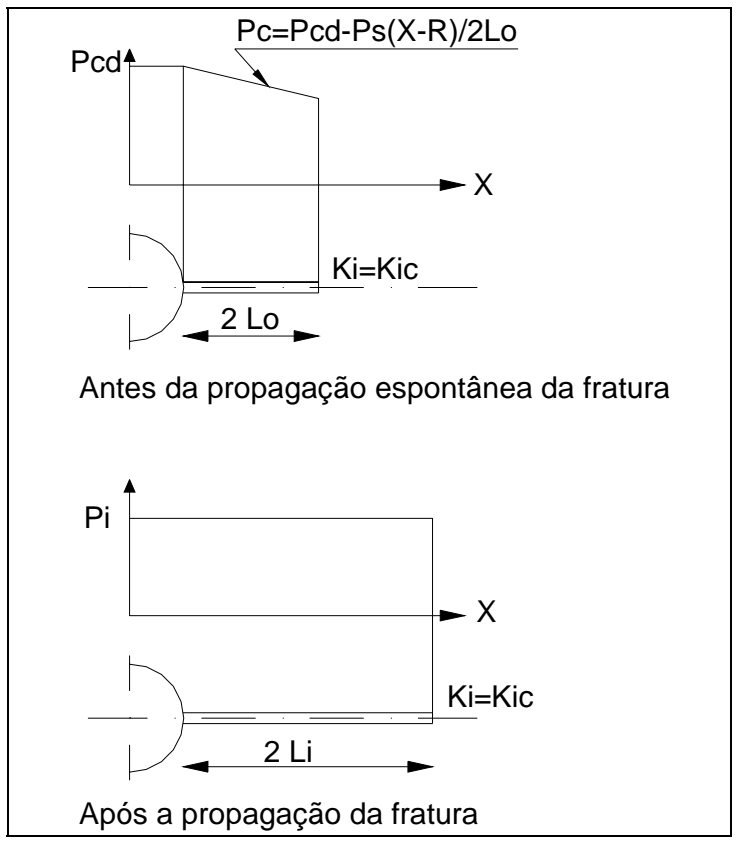

FIGURA 9 - Distribuição de pressão neutra (HAYASHI \& SAKURAY, 1989). $\mathrm{P}_{c d}$ é a pressão na cavidade que decai para $\mathrm{P}_{\mathrm{c}}$ no final da fratura; $\mathrm{P}_{0}$ e $\mathrm{L}_{0}$, respectivamente, pressão do fluido na fratura e extensão inicial da fratura. 


\subsection{Regime de escoamento das caldas de injeção}

Estudos de escoamento de fluidos em fraturas de maciços foram fundamentados nos conceitos desenvolvidos na hidráulica para escoamento em condutos circulares e entre duas placas paralelas. Ë importante lembrar que os tipos de regime do movimento dos fluidos são dois: laminar e turbulento.

No regime laminar, o fluxo ocorre em camadas, tendo cada partícula uma trajetória bem definida, com velocidade constante e no sentido do fluxo. A pressão ao longo do conduto com fluido em regime laminar é constante.

No regime turbulento, o movimento das partículas é desordenado, com deslocamentos transversais em relação ao fluxo principal. Neste caso, há oscilações de pressões e das velocidades ao longo do fluido.

A transição entre a passagem de um regime para outro pode ser definida como um terceiro tipo de escoamento.

As observações realizadas por Hagen, em 1839, e as experiências de REYNOLDS, em 1883 (apud BARRADAS, 1985), ilustram os diferentes regimes de escoamento. Estudo detalhado de mecânica dos fluidos pode ser obtido em SHAMES (1973).

A FIGURA 10 resume de forma ilustrada a experiência de Reynolds. Trata-se de um recipiente com registro (R), provido de um tubo de vidro, com saída reduzida para permitir a injeção de uma solução colorida. Ao abrir levemente o registro, a água escoa pelo conduto e o filete de solução colorida acompanha o movimento de forma retilínea, sem que ocorra a mistura. Nesta situação, denomina-se escoamento laminar o regime de fluxo d’água pelo conduto. Aumentando-se gradativamente o volume d'água, o filete começa a apresentar movimentos oscilatórios e, a partir de um certo volume, ele se desfaz completamente, misturando-se com a água, estado em que o regime é denominado turbulento. 
Os ensaios foram realizados para diferentes tipos de fluidos, escoando em condutos de vários diâmetros, observando-se, sempre, a ocorrência de mudança no regime de fluxo, a partir de um certo valor de velocidade de escoamento. Para esse valor, denominou-se velocidade crítica, sendo que, para valores superiores, o regime do fluxo é turbulento, e inferiores, laminar. Os ensaios permitiram concluir que a velocidade de fluxo, na qual se findou o regime laminar (velocidade crítica), era diretamente proporcional à viscosidade cinemática e inversamente proporcional ao diâmetro do conduto.

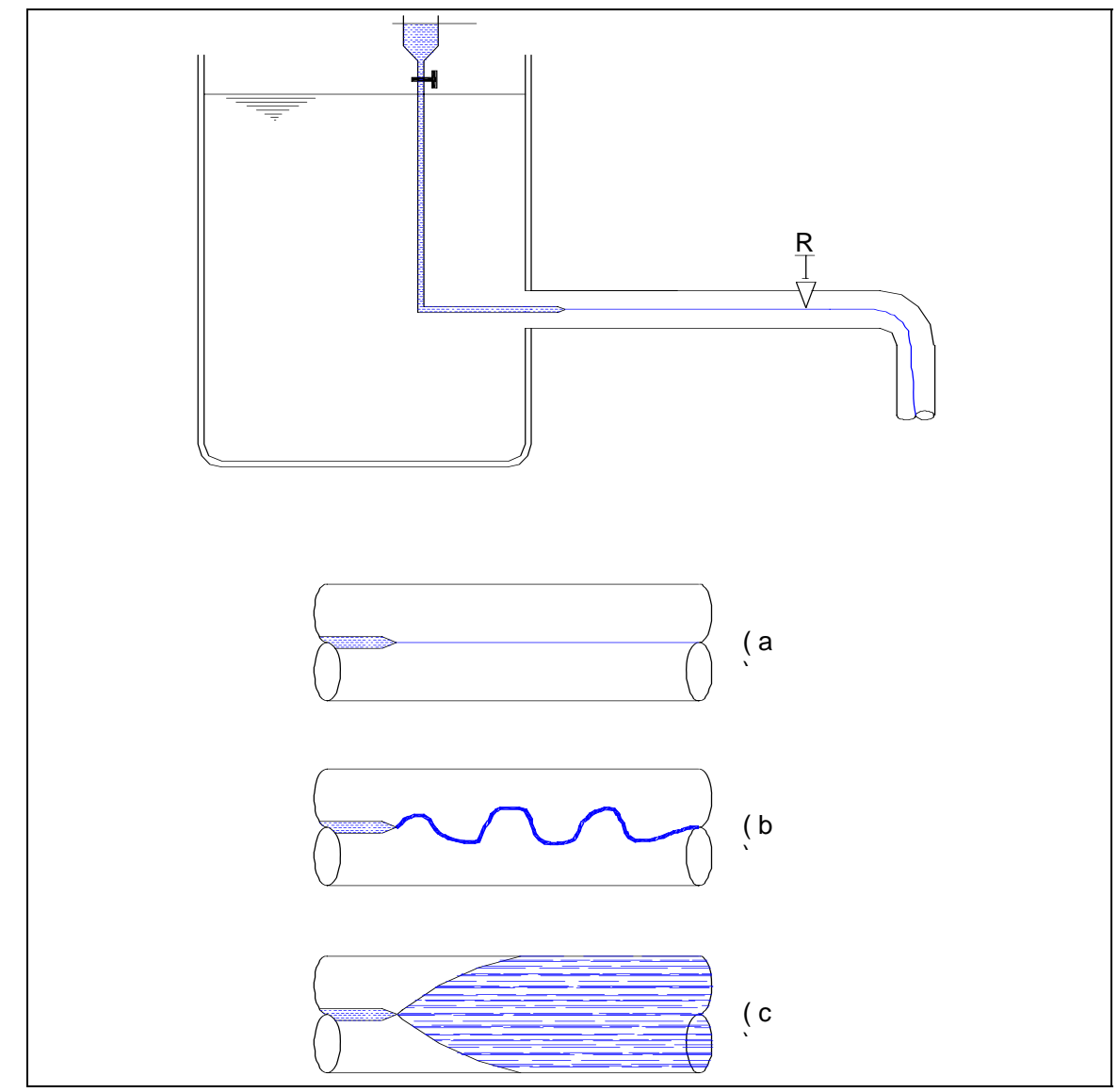

FIGURA 10 - Experiência de Reynolds (BARRADAS, 1985).

Assim, o número de Reynolds foi definido como:

$$
R e=\frac{V D}{v}
$$

onde: 
$R e=$ número de Reynolds;

$V$ = velocidade média $(\mathrm{cm} / \mathrm{s})$;

$v=$ velocidade cinemática do fluido, ou seja, a relação entre a viscosidade absoluta e a densidade do fluido;

$D$ = diâmetro hidráulico.

Para obter a velocidade crítica da eq.(1):

$V_{c r}=\frac{R e_{c r} v}{D}$

onde:

$V_{c r}=$ velocidade crítica;

$R e_{\mathrm{cr}}=$ número de Reynolds crítico;

A relação entre o diâmetro hidráulico e o raio é:

$D=2 \cdot R H \quad$ ou $\quad D=4 . A \cdot p$

onde:

$R H$ = raio hidráulico;

$A$ = área perpendicular ao sentido de escoamento;

$p$ = perímetro ao longo do qual se estabelece o atrito.

Portanto, no caso de uma fratura com abertura média $\boldsymbol{e}$ muito inferior em relação ao comprimento $\ell$, tem-se:

$$
D=\frac{4 e \ell}{2 \ell}
$$

ou

$D=2 . e$

(LOUIS, 1969) 
Quando $R e$ é inferior a $R e_{c r}\left(R e<R e_{c r}\right)$, o regime de escoamento é laminar, e para $R e$ superior a $R e_{c r}\left(R e>R e_{c r}\right)$, é turbulento.

A experiência de Reynolds mostrou que a transição entre os dois regimes situase entre 2000 e $4000(2000<R e<4000)$. Alguns autores afirmam que o intervalo inferior inicia-se em 2100 até 2500, demonstrando que o valor limite do fim do regime laminar é muito impreciso.

Os diferentes fluidos podem ser caracterizados pelos parâmetros reológicos, também denominados coeficientes da equação de fluxo, que variam, sensivelmente, com a temperatura e, de forma quase desprezível, com a pressão. Tais parâmetros são: tensão cisalhante, taxa de cisalhamento e viscosidade absoluta.

A tensão cisalhante $(\tau)$ corresponde à força tangencial que atua entre as camadas de fluido induzindo o cisalhamento.

A taxa de cisalhamento $(d v / d y)$ expressa o gradiente transversal de velocidade de fluxo, ou seja, corresponde à variação da velocidade em relação à distância transversal do escoamento.

O coeficiente de proporcionalidade entre a tensão cisalhante e a taxa de cisalhamento é a viscosidade absoluta $(\mu)$.

Em regime laminar, os fluidos podem ser agrupados em três modelos reológicos: de Newton; Bingham e Ostwald ou de Potência.

A relação entre a tensão cisalhante e a taxa de cisalhamento para os diferentes modelos de fluidos pode ser vista na FIGURA 11. No modelo de Newton, a tensão cisalhante é diretamente proporcional à taxa de cisalhamento. A FIGURA 11a mostra o reograma deste modelo.

No modelo de Bingham, a tensão cisalhante também varia linearmente com a taxa de cisalhamento; entretanto, é preciso aplicar uma força para iniciar o movimento do fluido (FIGURA 11b). 
O modelo de Ostwald ou de Potência, como o de Newton, inicia-se com uma pequeníssima tensão; porém, a proporcionalidade entre a tensão e a taxa de cisalhamento é elevada a um expoente $\mathbf{n}$ (FIGURAS 11c e 11d).

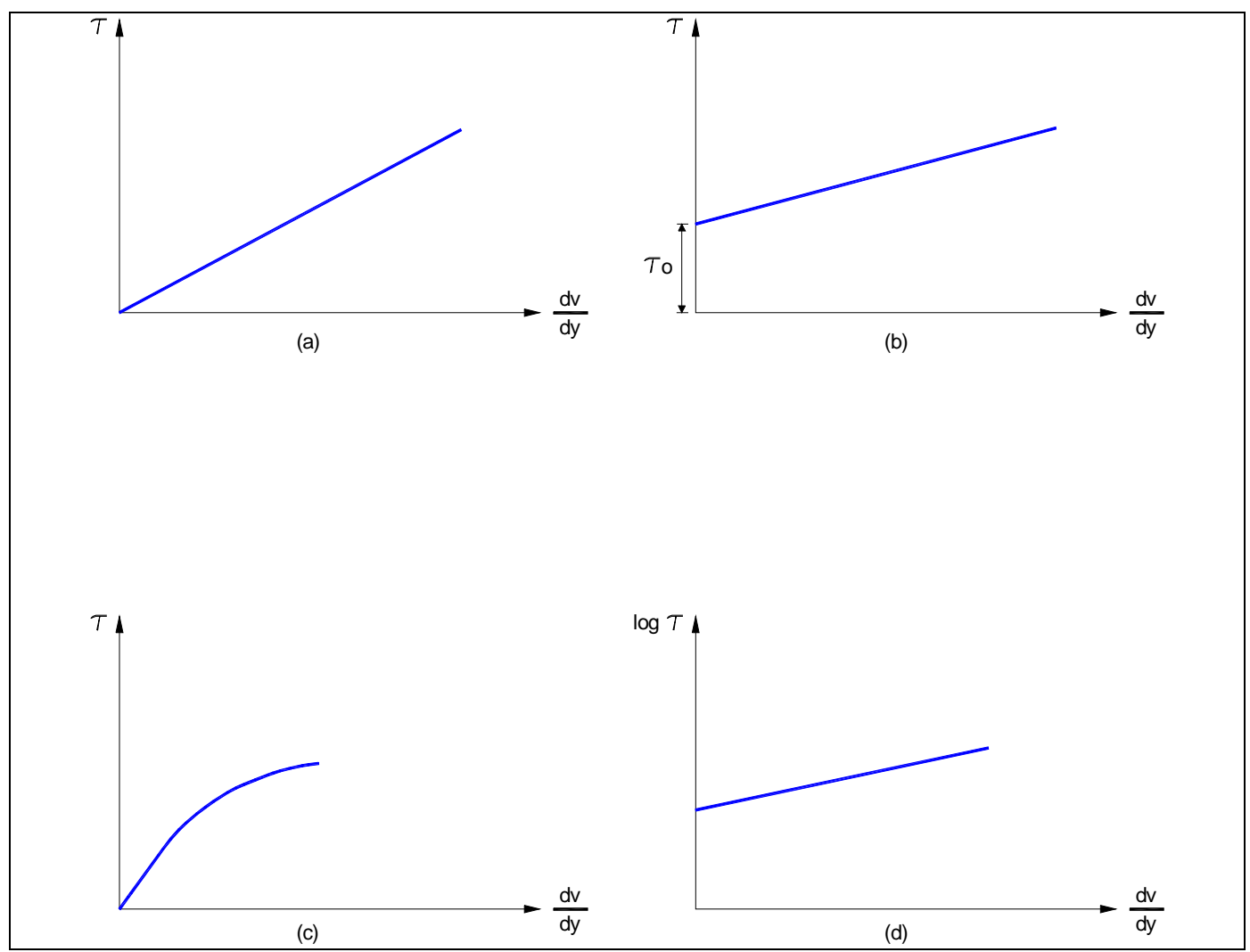

FIGURA 11 - Reograma característico dos fluidos: (a) Newtoniano; (b) Binghamiano; (c) e (d) PseudoPlástico (BARRADAS, 1985).

Caldas espessas, com fator água/cimento inferior a 1, comportam-se como corpos de Bingham com limite de escoamento e viscosidade plástica. No entanto, caldas com fator a/c superior a 1 comportam-se como fluidos Newtonianos, pois o limite de escoamento torna-se desprezível (IPT, 1972). Pode-se aplicar, portanto, a seguinte expressão para o escoamento de caldas Newtonianas, de acordo com Sinclair (apud INFANTI JÚNIOR \& NITTA, 1978): 


$$
Q=V A=\frac{e^{3} P}{6 \mu \ln \left(\frac{R}{r}\right)}
$$

onde:

$Q=$ vazão $(\ell / s)$;

$V=$ velocidade da calda na fissura $(\ell / \mathrm{s})$;

$A$ = área transversal da fissura a raio $R\left(\mathrm{~m}^{2}\right)$;

$\mathrm{P}=$ pressão em excesso no furo $\left(\mathrm{kgf} / \mathrm{m}^{2}\right)$;

$e=$ espessura da fissura (m);

$\mu=$ viscosidade absoluta $\left(\mathrm{kgf} . \mathrm{s} / \mathrm{m}^{2}\right)$;

$R=$ raio de influência (m);

$r=$ raio do furo $(\mathrm{m})$;

$\ln =$ logaritmo natural.

Análise de escoamento laminar de fluidos em tubos cilíndricos de comprimento $\mathbf{L}$ e raio $\mathbf{y}$ foi realizada por BARRADAS (1985), cujo entendimento e resultado são importantes para aplicação da técnica de injeção. A partir da verificação das forças que exercem no cilindro (FIGURA 12), observou-se que:

$$
(P 1-P 2) . \pi \cdot y^{2}=\tau \cdot 2 . \pi \cdot y \cdot \Delta L
$$

onde:

$(P 1-P 2)=$ diferença de pressão entre os pontos considerados;

$\Delta L=$ trecho do cilindro;

$y=$ raio do cilindro. 


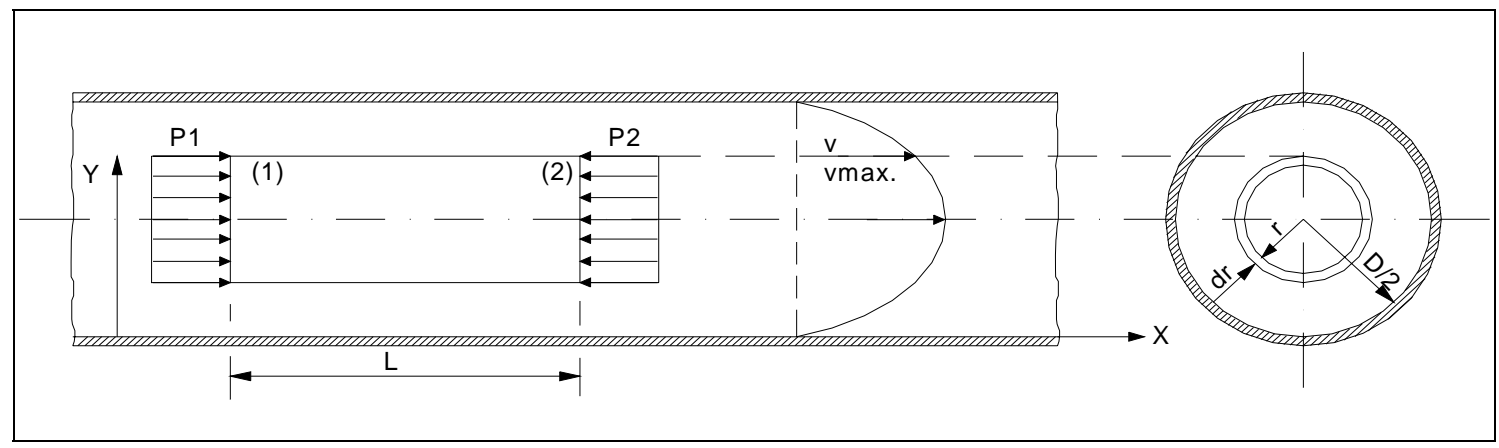

FIGURA 12 - Escoamento laminar em tubo cilíndrico (BARRADAS, 1985).

Pela lei de Newton, tem-se:

$$
\tau=\frac{-\mu d v}{d y}
$$

onde:

$\mu=$ viscosidade absoluta;

$(-)$ o sinal negativo $=$ acréscimos de $v$ e $y$ são opostos.

Substituindo a eq.(8) na eq. (7), tem-se:

$d v=\frac{-(P 1-P 2) d y}{2 L \mu}$

Integrando a eq.(9), tem-se:

$$
V=\frac{-(P 1-P 2) y^{2}}{2 L \mu+C}
$$

No regime laminar, a velocidade nas paredes é nula, alcançando valor máximo no eixo do tubo, de acordo com a Lei de Hagen-Poiseulle (SCHLICHTING, 1960 apud QUADROS, 1982).

Neste caso, se $y=e / 2$, a velocidade será zero $(v=0)$. Assim, tem-se:

$$
V=\left(\frac{P 1-P 2}{4 L \mu}\right)\left(\frac{e^{2}}{4}-y^{2}\right)
$$


Para o caso de velocidade máxima, o raio é zero $(\mathrm{y}=0)$, tem-se:

$$
V_{\max }=\frac{(P 1-P 2) e^{2}}{16 L \mu}
$$

A vazão $(Q)$ é dada pela relação da velocidade do fluido que passa pela área do cilindro $(Q=V . d A)$, que pode ser expressa pela fórmula da eq.(13):

$$
Q=\int V 2 \pi y d y
$$

Substituindo a eq.(11) na eq.(13) e integrando, tem-se:

$$
Q=\frac{(P 1-P 2) e^{2} \pi}{128 L \mu}
$$

Ao dividir a vazão pela seção reta do conduto, que é igual a $\left(\pi \cdot e^{2}\right) / 4$, obtém-se a velocidade:

$$
V=\left(\frac{P 1-P 2}{32 L \mu}\right) e^{2}
$$

ou seja:

$$
(P 1-P 2)=\frac{32 L V \mu}{e^{2}}
$$

A eq.(16) foi estabelecida por Poiseuille, em 1840 (apud BARRADAS, 1985) e exprime a perda de carga de qualquer fluido em tubulações de diferentes diâmetros, com escoamento laminar.

Utilizando a equação de Darcy-Weisbach, tem se:

$$
(P 1-P 2)=\left(\frac{L \lambda}{D}\right)\left(\frac{V^{2}}{2 g}\right)
$$


onde:

$\lambda=$ coeficiente de proporcionalidade conhecido como coeficiente de resistência ao fluxo;

$g$ = aceleração da gravidade;

$D$ = diâmetro hidráulico, ou seja, $D=$ 2.e.

Dividindo a equação estabelecida por Poiseuille (equação 16) pela massa específica do fluido $(\gamma=\rho . g)$, pode-se obter:

$$
\frac{P 1-P 2}{\gamma}=\lambda=\frac{32 L V \mu}{\rho g e^{2}}
$$

Aplicando a eq.(18) na eq.(17) e utilizando a equação de Reynolds eq.(1), temse:

$$
\lambda=64 / R e
$$

Portanto, para o escoamento do fluido no regime laminar em um tubo cilíndrico, o coeficiente de resistência ao fluxo $(\lambda)$ depende apenas do número de Reynolds.

Ao estudar a percolação de fluido pelas fraturas dos maciços rochosos, QUADROS (1982) e CRUZ (no prelo) também realizaram análise teórica sobre o escoamento; porém, neste caso, os autores admitiram o fluxo entre duas placas paralelas perfeitamente polidas, afastadas entre si de uma distância e (FIGURA 13). As forças que exercem em um cilindro de fluido de raio $\mathbf{y}$ e comprimento $\mathbf{L}$ são:

$$
(P 1-P 2) \cdot 2 \cdot y \cdot L=\tau .2 . \pi \cdot y \cdot L \cdot 1
$$




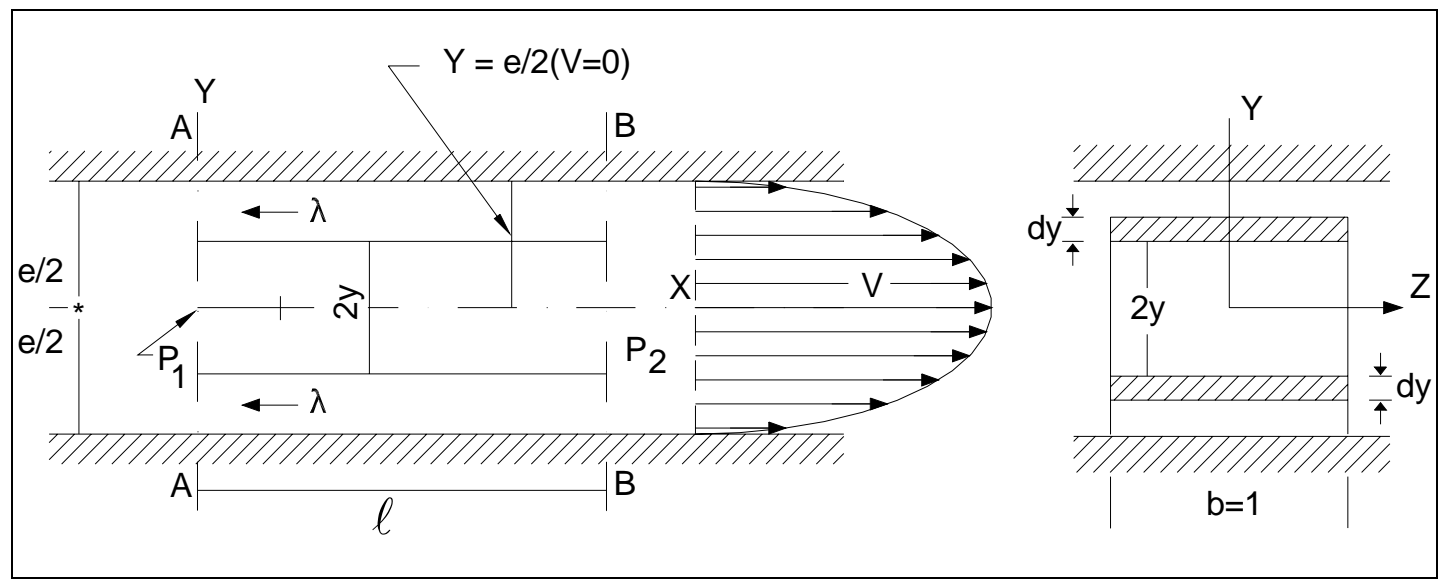

FIGURA 13 - Fluxo entre duas placas paralelas perfeitamente polidas (QUADROS, 1982).

Adotando-se o mesmo desenvolvimento aplicado para o caso de escoamento em um tubo cilíndrico, os autores demonstraram e concluíram que:

$$
\lambda=\frac{96 v}{V D}
$$

ou seja:

$$
\lambda=96 / R e
$$

Também neste caso, para o escoamento do fluido em regime laminar entre placas paralelas, o coeficiente de resistência ao fluxo $(\lambda)$ depende apenas do número de Reynolds (QUADROS, 1982 e CRUZ, no prelo).

Em regime turbulento, a distribuição geométrica do fluxo do fluido entre duas placas polidas é mais uniforme, se comparada com a laminar. A FIGURA 14 exibe um perfil ilustrativo entre os dois regimes.

Como afirmado anteriormente, o regime turbulento caracteriza-se pela variação da velocidade de escoamento, oscilações da pressão interna no conduto, animação das partículas que descrevem movimentos de agitação e com velocidades transversais ao sentido do escoamento. Neste caso, a lei de atrito viscoso de Newton não se aplica, pois durante o escoamento de um fluxo turbulento não há laminação do líquido. 


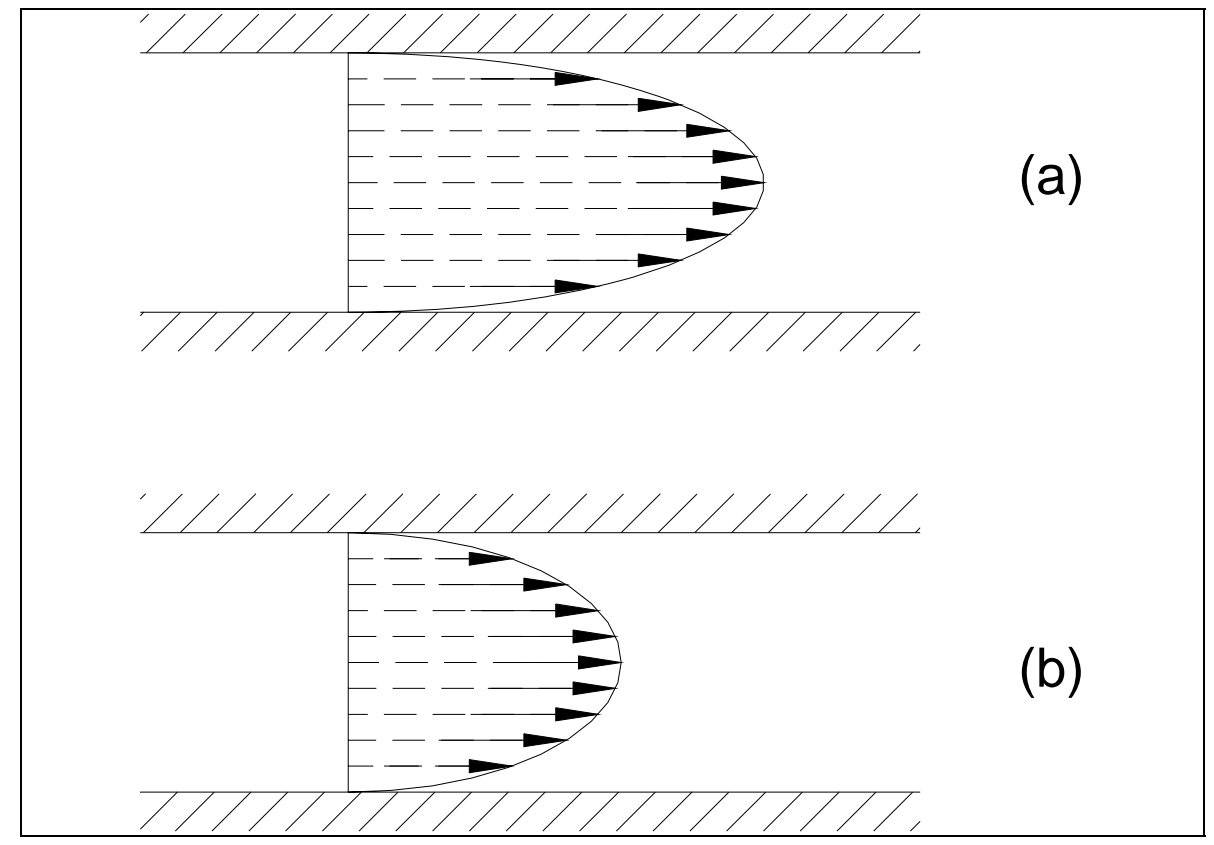

FIGURA 14 - Distribuição de velocidades entre placas paralelas: a) laminar e b) turbulento (QUADROS, 1982).

Ainda, no regime turbulento, a perda de carga por atrito viscoso não é linear. Observa-se um salto na "resistência" e um aumento mais brusco, segundo uma curva próxima a uma parábola de segunda potência “devido à complexidade do regime turbulento e das dificuldades de sua investigação analítica, não existindo teorias rigorosas sobre o assunto" (CRUZ, no prelo).

Nos maciços rochosos, o fluxo d’água é controlado "pela continuidade, forma $e$ dimensões dos vazios, e ainda por possíveis reações químicas que se processam entre a matriz rochosa e/ou materiais argilosos presentes" (CRUZ, no prelo). Em geral, as velocidades de fluxo na matriz de maciços rochosos são muito baixas, o fluxo é laminar e a Lei de Darcy prevalece.

$$
V=k . i
$$

onde:

$V$ = velocidade média; 
$k$ = coeficiente de permeabilidade;

$i$ = gradiente hidráulico.

Para CRUZ (no prelo), o fluxo de água em descontinuidades rochosas vai de laminar a turbulento, em grande parte influenciado pela rugosidade das paredes, pelo gradiente hidráulico, pela forma e dimensões dos vazios, pelos materiais de preenchimento, por possíveis reações químicas da água com os minerais da rocha, entre outros fatores. O autor afirmou ainda que, nas descontinuidades do tipo fissuras, as leis que regem a percolação são semelhantes às do "fluxo entre placas”. Porém, para as descontinuidades muito abertas, o fluxo é do tipo “tubos” com "bloqueios” localizados, devido às variações da forma da abertura e dos preenchimentos existentes.

BARRADAS (1985) realizou estudo das características reológicas da calda de solo-cimento, a partir de ensaios de perda de carga em tubulação. Afirmou que a calda de solo-cimento se aproxima do modelo de Bingham; porém, quando ela está submetida a uma determinada taxa de cisalhamento, se comporta como fluido Newtoniano. Para isso, o autor tomou como base a calda de solo-cimento utilizada no tratamento da Barragem de Balbina, com massa específica de 1,3 kgf/ $/ \mathrm{cm}^{3}$, e calculou a equação reológica da calda passando por uma tubulação de $\phi=1$ ”. Ao final dos cálculos, o autor obteve o número de Reynolds igual a 2458. Ainda que esse valor obtido tenha superado em quase $25 \%$ o valor crítico $\left(R e_{c r}=\right.$ 2000), BARRADAS (op. cit.) admitiu que o fluxo predominante nas fraturas hidráulicas do maciço tratado foi do tipo laminar. Partindo dessa premissa, calculou o coeficiente de resistência ao fluxo $(\lambda)$, obtendo:

$$
\lambda=64 / R e=0,026
$$


E aplicando a lei de Darcy, eq.(16), o autor demonstrou por meio de cálculos que a perda de carga na tubulação se aproximava do valor obtido no ensaio de campo (0,026 $\mathrm{kgf} / \mathrm{cm}^{2} / \mathrm{m}$ ) para uma vazão de $60 \ell / \mathrm{min}$.

A partir da análise dos resultados, BARRADAS (1985) afirmou que o regime de escoamento da calda de solo-cimento, naquelas condições, era do tipo laminar, pois " $a$ perda de carga variou linearmente com a velocidade". Ressalta-se que nos experimentos de LENCASTRE (1972) com fluxo d’água, com diferentes velocidades, em condutos de diferentes diâmetros, os resultados obtidos nos ensaios mostraram que a perda de carga na tubulação está relacionada com as características e condições físicas da tubulação.

\subsection{Traços de caldas}

A granulação da mistura de cimento e água é definida pelo tamanho dos grãos maiores contidos no cimento que, em geral, possuem dimensão da ordem de 200 micras, excetuando-se a classe do cimento especial. Observações da presença de grãos maiores no cimento e recomendações sobre sua limitação, mesmo em diminutas quantidades, já haviam sido realizadas por SABARLY (1968), quando estudou a injetabilidade das caldas nas fraturas das rochas e verificou que grânulos maiores de cimento impediam a penetração das caldas.

Preocupados com esta questão, TATAMIYA et al. (1971) realizaram ensaios em caldas de cimento utilizadas nos tratamentos da Usina de Ilha Solteira e verificaram que as mais ralas apresentavam maior penetração nas fendas, porém eram pouco estáveis, tinham alto fator de sedimentação e baixa resistência mecânica após a cura. Para estabelecer o melhor traço das caldas de injeção, os autores propuseram realizar ensaios com a finalidade de obter a curva Tempo de Escoamento X Fator de Sedimentação. A partir desta curva, os autores sugeriram que fossem determinadas as caldas mais injetáveis. Para a escolha da 
melhor calda, os autores afirmaram que é necessário, ainda, observar compatibilidade entre a facilidade de injeção e a resistência mecânica da calda após a cura.

A estabilidade das caldas de cimento pode ser obtida através do controle do volume de água em relação ao do cimento ou por meio da adição de materiais finos, como, por exemplo, a bentonita, cujas propriedades foram estudadas por JONES (1969). O aumento do teor de água da mistura altera as características do fluido, facilitando sua penetração pelas fissuras, principalmente daquelas mais fechadas; porém, esta medida reduz a resistência das caldas endurecidas. Para aproveitar esta vantagem de maior penetrabilidade das caldas, vários consultores internacionais sugerem iniciar as injeções com caldas mais ralas, por exemplo, água:cimento $=2: 1$, em peso, e, em algumas vezes, até 10:1, aumentando-se progressivamente a quantidade de cimento (menor relação de a:c) durante o processo de injeção. Entretanto, observa-se que nos tratamentos efetuados em maciços rochosos, especialmente para fundações de barragens brasileiras, as caldas utilizadas são mais viscosas com traço, em peso, de água/cimento variando desde 1:1 até 0,4:1,0. Tal afirmação pode ser verificada nos trabalhos de tratamento de maciços nas obras do Túnel de Pirapora, Barragem de Taquaruçu (AZEVEDO, 1993) e em outras obras (SAMPAIO, 1976; RÉ, 1976; IPT, 1979; GOMBOSSY et al., 1981; BARBI, et al.1981; MACHADO et al., 1984; MARRANO et al., 1984).

BARBI et al. (1981) propuseram emprego dessas caldas mais viscosas por entenderem que a estabilidade das caldas é um fator importante na fixação do cimento nas fraturas do maciço.

Trabalhos realizados no tratamento do maciço rochoso do túnel de descarga da Barragem de Pirapora e na fundação da eclusa da Barragem de Edgard de Souza mostraram que caldas mais ralas, sem estabilidade, foram transportadas pelo fluxo d'água (IYOMASA et al., 1997). 
É comum o emprego de produtos químicos, em proporções relativamente baixas de até $5 \%$ em peso do cimento, para melhorar a qualidade das caldas de água/cimento durante o processo de injeção. As substâncias tensoativas diminuem a tensão superficial das caldas e melhoram a curva de injetabilidade, enquanto que os aceleradores de "pega" são empregados quando se deseja obter resistências mecânicas relativamente altas, nas primeiras horas após a injeção. Outros produtos, como os expansores, servem para diminuir a sedimentação; entretanto, seu uso pode ser limitado, pois, em contato com a estrutura metálica, podem iniciar e acelerar o processo de oxidação. A fluidez da calda pode ser aumentada com emprego de dispersante ou escória de alto-forno. Essa mistura facilita o bombeamento da calda durante a injeção, além de permitir maior penetração nas fissuras. De forma oposta, as cinzas vulcânicas são utilizadas para diminuir a fluidez da calda e melhoram sua estabilidade (IPT, 1984a).

Nos trabalhos de construção da cortina de vedação ou impermeabilização das estruturas da Barragem de Taquaruçu, foram utilizados diversos traços de caldas de cimento, diante do comportamento das absorções médias do maciço rochoso. Os trabalhos de injeção foram iniciados com caldas mais ralas, com relação de água:cimento de até 1:1, em peso. Nestas misturas, foi adicionada 3\% de bentonita em relação à quantidade de cimento para melhoria da estabilidade e diminuição do fator de sedimentação. Nas caldas a:c = 0,7:1,0, a quantidade de bentonita utilizada foi de $2 \%$ e para as de $0,5: 1,0$, não foi necessário seu emprego. Nos trechos de maior absorção, o tratamento foi realizado com injeção de argamassa na proporção de a:c:ar = 0,5:1,0:0,5 (água:cimento:areia), em peso (AZEVEDO, 1993).

O método de injeção em maciços terrosos difere das técnicas utilizadas nos tratamentos das rochas sãs ou pouco alteradas, uma vez que é praticamente impossível fixar os obturadores na parede do furo do maciço terroso. Assim, a injeção nesses maciços requer 
a instalação de tubos de PVC, fixados por meio de calda (bainha), contendo válvulas tipo manchete em intervalos previamente estabelecidos.

Para confecção das bainhas no tratamento da fundação da barragem de terra de Balbina, foi utilizada calda de solo-cimento, devido às suas características de deformabilidade, baixa resistência e à menor possibilidade de ocorrência de trincas de contração, após a cura. A opção do emprego de material de baixa resistência (em relação ao cimento) para confecção das bainhas foi em função da facilidade em se abrir as válvulasmanchete por meio das caldas de injeção (RÉMY et al., 1985).

A combinação do solo com o cimento, sob condições controladas de mistura e de densidade, produz um material com diferentes características físicas para aplicação em Geologia de Engenharia. Estas propriedades dependem de importantes fatores, como: da natureza do solo; da quantidade e do tipo de cimento; do efeito da umidade; da mistura e das condições de cura (ANDRADE FILHO, 1989).

O traço utilizado para confecção das bainhas, na obra de Balbina, foi de $285 \mathrm{~kg}$ de cimento por metro cúbico de calda, segundo SIQUEIRA et al. (1986) e MOREIRA et al. (1990). A calda de injeção utilizada nesta obra continha apenas $168 \mathrm{~kg}$ de cimento, $310 \mathrm{~kg}$ de solo e 860 kg de água por metro cúbico de calda.

Nos trabalhos realizados na Barragem de Rasgão, as bainhas foram confeccionadas com traços mais ricos em cimento devido à necessidade em reduzir o tempo dos trabalhos de tratamento. Além disso, um dos critérios estabelecidos em projeto exigia que, após o encerramento da injeção em um furo, o próximo, deveria ser realizado pelo menos 12 m distante do primeiro, para evitar interferências danosas na injeção. Essa exigência na obra de Rasgão, onde as condições topográficas locais e a pequena área de trabalho dificultava o deslocamento dos equipamentos, indicava que a campanha de injeção poderia ultrapassar o tempo estabelecido no cronograma do projeto. Por esse motivo, foi determinado o emprego de caldas mais ricas em cimento também para a confecção das 
bainhas. O traço da calda de solo-cimento utilizado na Usina de Rasgão foi, em peso, na proporção de a:ag:c = 1:2:3 (água:argila:cimento). Para confeccionar um metro cúbico de calda, com essa proporção, são necessários cerca de 400 kg de cimento, 267 kg de argila e $133 \ell$ de água. Tal quantidade de cimento é muito próxima do valor empregado por BARBEDETE \& SABARLY (1981) na Barragem de Bin el Quidane, em Marrocos.

Nos trabalhos realizados na unidade industrial da Cooperativa Central de Laticínios do Estado de São Paulo, as caldas, por metro cúbico, continham materiais nas seguintes proporções (PROGECONSULT, 1997):

a) Para injeção da bainha: cimento 160 kg; solo 340 kg; e água 820 l;

b) Para injeção do solo: cimento $100 \mathrm{~kg}$; solo $340 \mathrm{~kg}$; e água $840 \ell$.

Os valores médios entre a relação de solo e água e as quantidades de cimento utilizadas na confecção das caldas da bainha e de injeção, das diferentes obras, são apresentadas na TABELA 1.

TABELA 1 - Valores médios das proporções dos materiais usados na confecção de caldas por obra (a = água; ag = argila; e cim. = cimento).

\begin{tabular}{c|c|c|c|c}
\hline \multirow{2}{*}{ Local - obra } & \multicolumn{2}{|c|}{ Bainha } & \multicolumn{2}{c}{ Injeção } \\
\cline { 2 - 5 } & Relação ag:a & $\mathrm{Kg} \mathrm{cim./ \textrm {m } ^ { 3 }}$ & Relação ag:a & $\mathrm{Kg} \mathrm{cim./ \textrm {m } ^ { 3 }}$ \\
\hline Balbina & 0,30 a 0,36 & 285 & 0,30 a 0,50 & 168 \\
\hline Rasgão & 0,67 & 400 & 0,50 & 200 \\
\hline Cooperativa & 0,40 & 160 & 0,40 & 100 \\
\hline
\end{tabular}

\subsection{Ensaios em caldas}

A manutenção da qualidade das caldas de injeção é uma preocupação constante dos técnicos que executam tratamentos de maciços, principalmente daqueles que buscam reduzir percolações de água pelas fundações de barragens, como pode ser comprovada em inúmeras publicações, como a de KANJI (1990). Para avaliar a qualidade técnica das caldas 
ou para obter seus parâmetros reológicos, é necessária a determinação desses valores através de ensaios laboratoriais.

Em geral, a calda de cimento deve ser fluida suficiente para penetrar nas fissuras das rochas, mas deve apresentar-se estável e com resistência final necessária para atender às solicitações da obra. Uma série de medidas preventivas, para eliminar fatores que pudessem influenciar na qualidade das caldas de cimento, foi proposta por BARBI et al. (1981). Essas medidas estão fundamentadas nos trabalhos que os autores executaram durante o tratamento da fundação da Barragem de Itaipu. Além dos tradicionais ensaios de laboratório e de campo, que são submetidas as caldas de cimento, os autores sugeriram que fossem tomados cuidados especiais na estocagem dos componentes (cimento, bentonita e aditivos) e na preparação da mistura com água refrigerada. Outra medida adotada pelos autores, para manter a qualidade da calda fabricada, foi incluir uma serpentina, envolta em gelo, na tubulação de retorno do circuito de injeção. Essas medidas adotadas pelos autores não foram suficientes para melhoria e manutenção da qualidade das caldas, como foi comprovado quando realizaram o estudo comparativo entre os resultados dos parâmetros reológicos extraídos no campo e no laboratório, bem como das caldas fabricadas nas diferentes centrais de fabricação.

Com efeito, BARBI et al. (1981) notaram que a principal diferença entre as centrais de fabricação e as equipes de injeção era no tempo de hidratação da bentonita, utilizada como aditivo para reduzir a sedimentação das caldas. Por esse motivo, resolveram investigar a influência desse aspecto da hidratação da bentonita na qualidade das caldas e verificaram variações significativas no tempo de escoamento das caldas, no fator de sedimentação, na viscosidade e no limite de escoamento (Yield Point), como mostram os gráficos da FIGURA 15. Ao concluírem os estudos os autores sugeriram o tempo mínimo de hidratação da bentonita de 8 horas. Ao analisar os gráficos elaborados pelos autores (FIGURA 15), nota-se que são mantidas inalteradas as características reológicas da calda 
somente a partir de 24 horas de hidratação da bentonita. Essa observação diferencia-se da sugestão apresentada por BARBI et al. (1981).

Outra sugestão apresentada pelos autores foi circular a lama bentonítica pelos equipamentos no início dos turnos de trabalhos para homogeneizá-la, tendo em vista a propriedade tixotrópica da bentonita, ou seja, da facilidade do material se aglutinar originando pontos de alta concentração.

O uso de misturadores de alta rotação e com circulação vertical é outra maneira possível de se conseguir a homogeneização da lama de bentonita, como foi empregado na obra de Rasgão para fabricação de caldas de solo-cimento.

A influência dos misturadores nas características reológicas da calda durante sua fabricação foi estudada por JEFFERIS (1982). Em diversos experimentos realizados, em especial nas caldas contendo bentonita, este autor comprovou que os equipamentos de alta rotação produziam caldas mais homogêneas e com características reológicas constantes, ao contrário dos equipamentos de baixa rotação.

Ainda que existam normas para estabelecer as características técnicas mínimas dos materiais componentes da calda (cimento e bentonita), é comum ocorrer variações na reologia da calda, principalmente se forem utilizados produtos de diferentes fabricantes. Para contornar esse problema, BARBI et al. (1981) sugeriram que as caldas fossem confeccionadas com traço flexível. Essa técnica permite o ajuste das caldas a partir das características dos produtos utilizados. Para isso, os autores propuseram obter, por meio de ensaios laboratoriais, a relação bentonita/cimento em função da viscosidade da bentonita hidratada. 


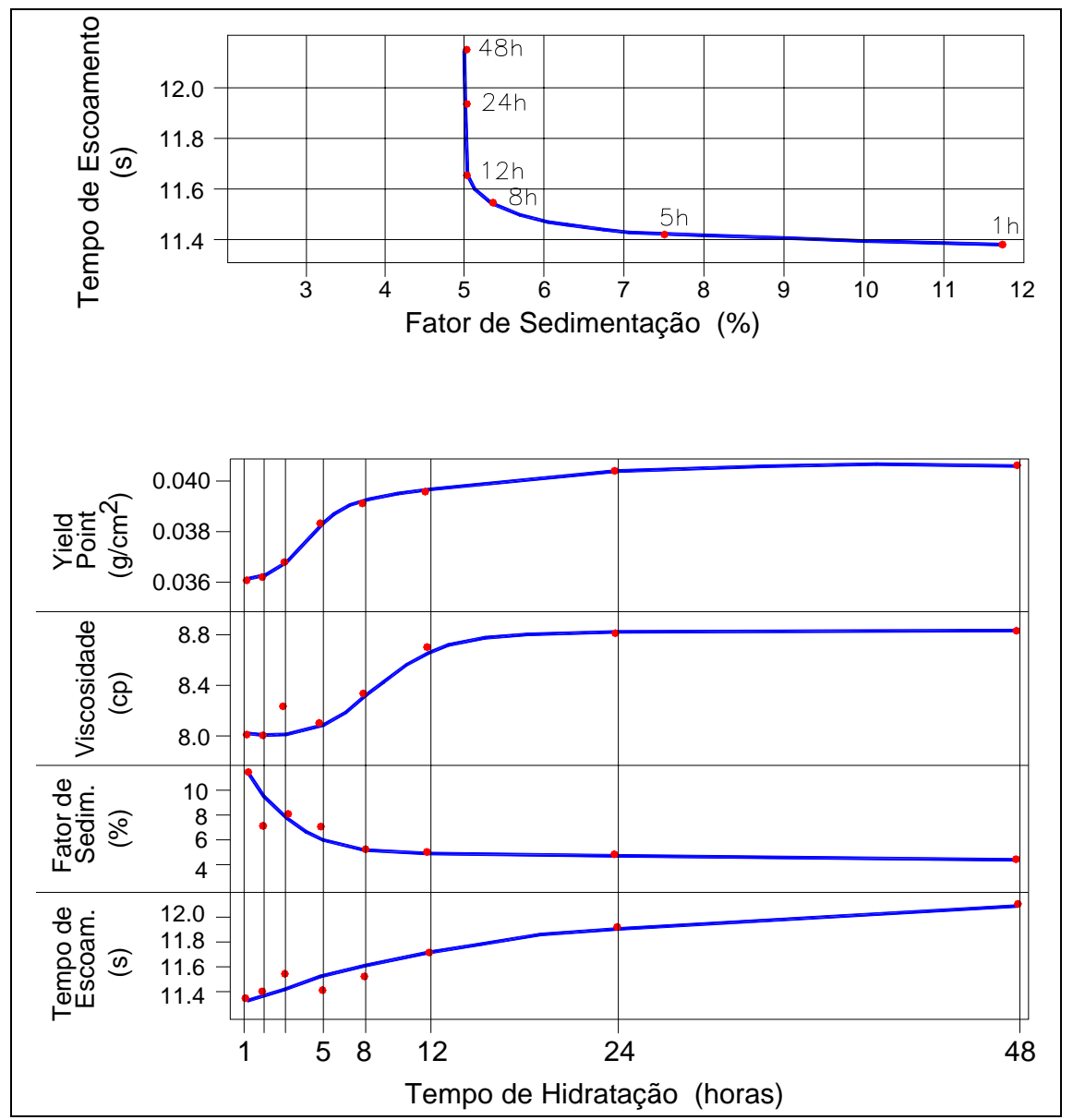

FIGURA 15 - Comportamento da calda com o tempo de hidratação da bentonita (BARBI et al., 1981).

Cabe destacar que existem, também, normas (ABNT, 1983a) que tratam dos métodos executivos dos ensaios laboratoriais para obter os parâmetros relativos a: fluidez, vida útil, exsudação, expansão e resistência mecânica das caldas. São parâmetros que representam as características reológicas básicas da calda que, durante todas as etapas de trabalho de injeção, devem sofrer controle sistemático. Tais ensaios, descritos em norma da Associação Brasileira de Normas Técnicas - ABNT, são brevemente abordados com a finalidade de apresentar os critérios existentes sobre injeção de calda de cimento, contrariamente aos tratamentos com injeção de solo-cimento.

A fluidez da calda pode ser obtida a partir de um viscosímetro de cilindros coaxiais (FIGURA 16). O ensaio consiste em submeter a calda (modelo de Bingham 
Plástico) ao corte pela rotação do cilindro externo do aparelho. Para cada um dos valores de velocidade já estabelecidas no aparelho (3, 6, 100, 200, 300, e 600 rpm), deve-se registrar o valor correspondente da tensão de cisalhamento transmitida pelo fluido ao cilindro interno. Da curva viscosimétrica, obtém-se, por meio do coeficiente angular entre os pontos de 300 e 600 rpm, a Viscosidade Plástica, em centipoises (FIGURA 17). A partir da diferença entre a leitura da viscosidade em 300 rpm e a Viscosidade Plástica, obtém-se o Limite de Escoamento (Yield Point).

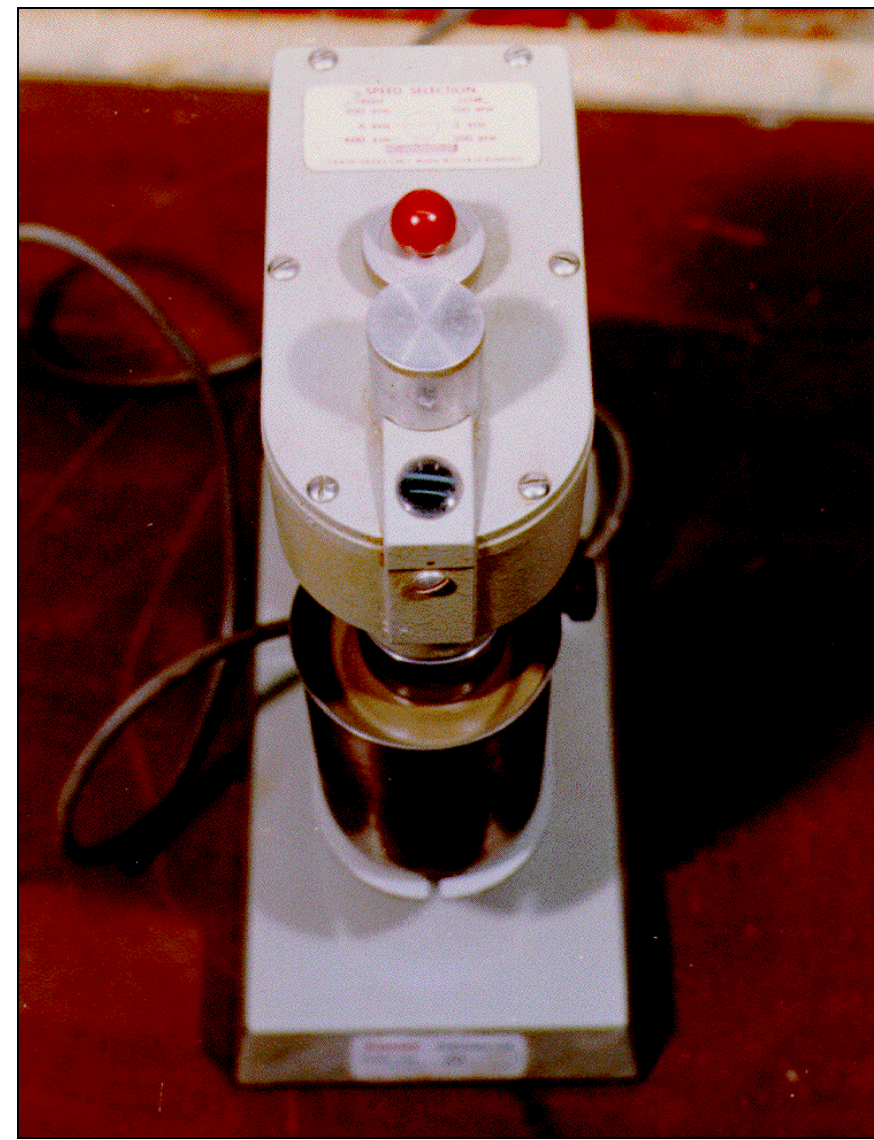

FIGURA 16 - Viscosímetro Fann empregado no laboratório para determinação de caldas de cimento. 


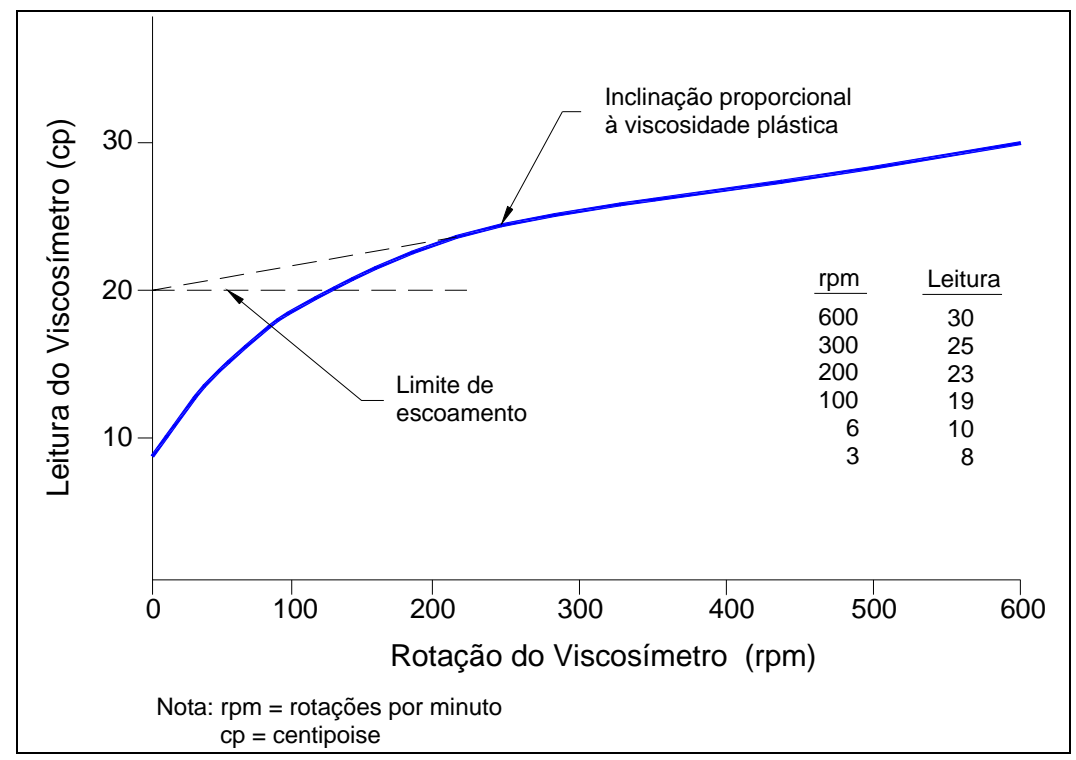

FIGURA 17 - Curva viscosimétrica do modelo Bingham Plástico.

O tempo de escoamento da calda está diretamente relacionado à sua viscosidade e pode ser medido por meio de um funil ou cone padronizado (ABNT, 1983b). O ensaio consiste em medir o tempo necessário para escoar 1 litro de calda pelo funil ou cone com dimensões padronizadas (FIGURA 18). Vale lembrar que, durante o desenvolvimento do presente trabalho, foram encontrados pelo menos dois diferentes tipos de cones utilizados nos laboratórios brasileiros: o primeiro com diâmetro de 4,75 mm para a saída da calda e o outro com $10 \mathrm{~mm}$.

O fator de sedimentação da calda é outra característica importante das caldas de cimento. Nos trabalhos de injeção, deve-se procurar obter caldas com valores baixos de sedimentação para que não sobrem vazios na estrutura após a cura da calda introduzida. Estes vazios podem vir a constituir caminhos preferenciais de percolação e, no caso de maciços terrosos, podem provocar erosões do tipo piping. A técnica do ensaio consiste em repousar $1 \ell$ de calda, numa proveta, e medir, em porcentagem, a sedimentação após decorridos 120 minutos em repouso.

A norma NBR-7683 (ABNT, 1983c) trata da medida da determinação dos índices de exsudação e expansão. No primeiro, deve ser medido o volume de água segregado 
da calda, expresso em porcentagem do volume inicial e, no segundo, a variação de volume da parte sólida.

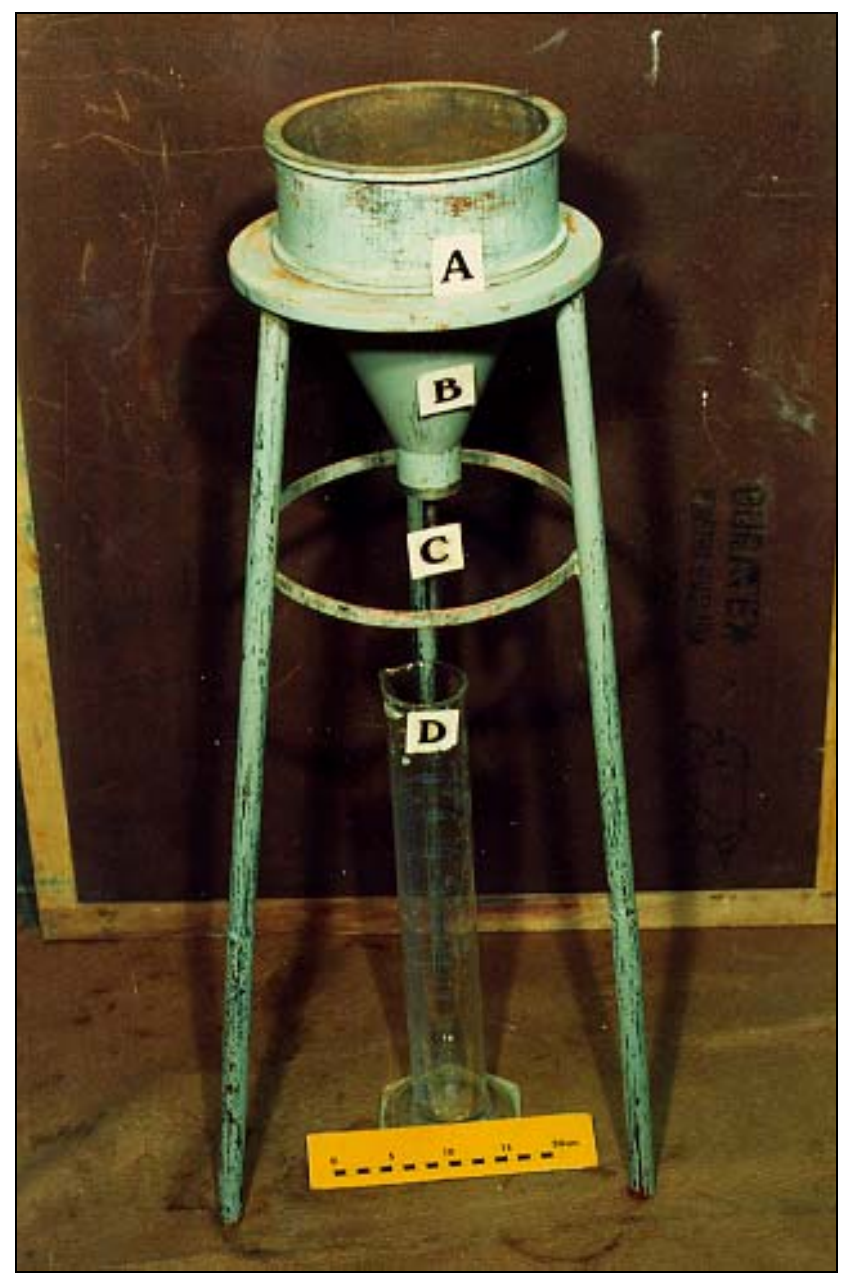

FIGURA 18 - Cone ou funil utilizado no ensaio para determinação do tempo de escoamento: (A) suporte do cone; (B) cone de Marsh; (C) abertura para saída da calda; (D) proveta com capacidade de um litro.

A vida útil da calda de cimento é determinada pelo tempo de início de pega e deve ser medido por meio do aparelho de Vicat (FIGURA 19). Anota-se o tempo decorrido entre o final da preparação da calda até a penetração pela agulha na pasta, de, no máximo, 1 mm. A vida útil das caldas de cimento, em geral, é da ordem de 2 horas.

Outra técnica empregada para se determinar a vida útil das caldas de cimento é por meio do ensaio no funil de Marsh com diâmetro de saída da calda de 4,75 mm. A norma 
NBR-7685 (ABNT, 1983e) trata dos critérios de execução deste ensaio e determina o limite de 25 segundos para o tempo de escoamento da calda ainda em condições de uso.

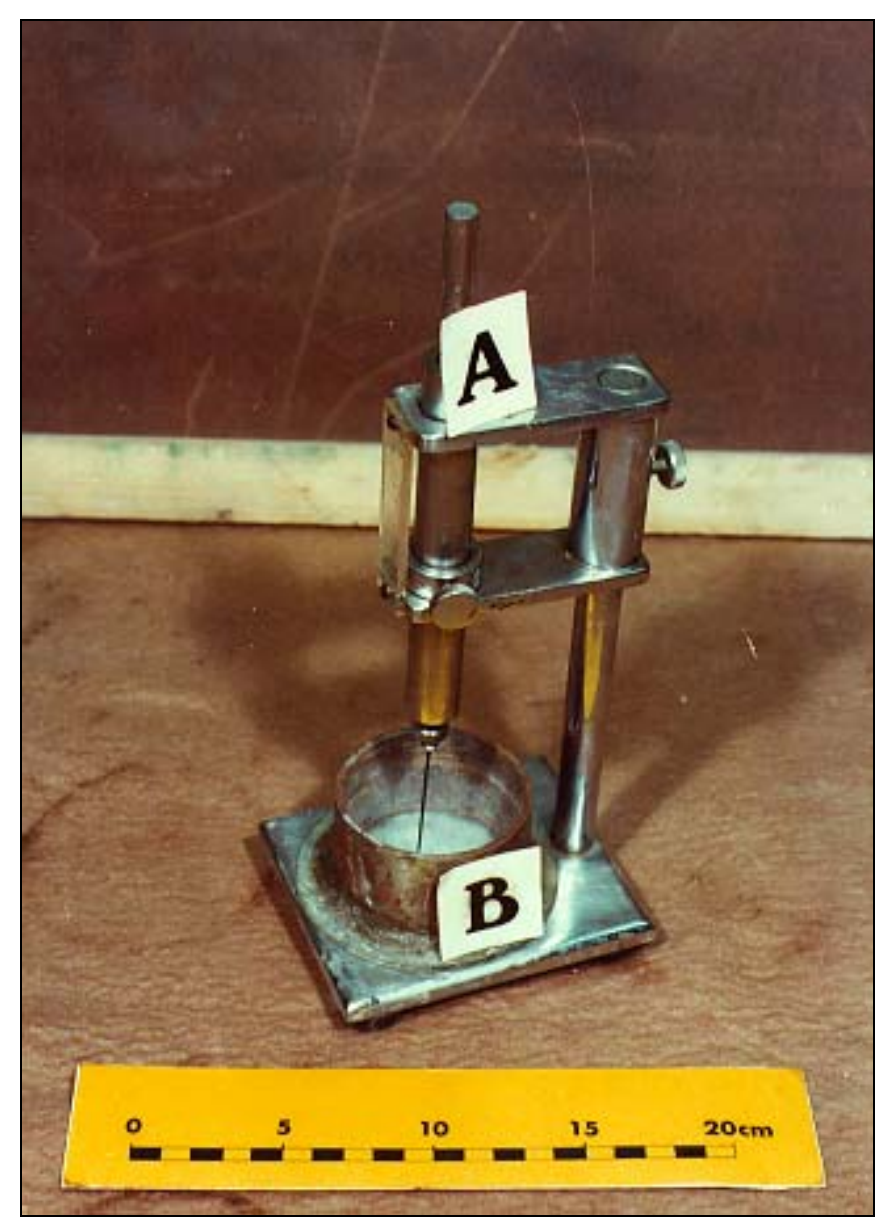

FIGURA 19 - Aparelho de Vicat para determinação do início de pega da calda: (A) êmbolo com uma agulha padrão na extremidade inferior; (B) recipiente para colocação da calda a ser ensaiada.

A resistência à compressão uniaxial é obtida por meio da ruptura de corpos-deprova cilíndricos com $5 \mathrm{~cm}$ de diâmetro e $10 \mathrm{~cm}$ de altura, em prensa previamente calibrada. Os ensaios podem ser realizados com idades das amostras de 7, 14 e 28 dias (ABNT, 1983d).

Preocupado em manter a qualidade da calda durante os trabalhos de injeção, SAMPAIO (1988) recomendou outros ensaios, como a determinação da resitência da calda submetida ao processo de lixiviação, empregando-se o extrator tipo Soxhlet. Sugeriu, ainda, a obtenção da massa específica por meio da balança de Baroid; a determinação das 
características físico-químicas dos materiais componentes das caldas; a medição da capacidade dos equipamentos em rotacionar as caldas e a obtenção das temperaturas do ambiente e das caldas.

Ensaios em caldas de solo-cimento, também denominadas caldas binárias, foram propostos por BARBEDETE \& SABARLY (1981). Com a finalidade em diminuir o número de ensaios necessários para determinação das características da lama durante os trabalhos de injeção, os autores propuseram um método prático de representação dessas caldas por meio de diagrama triangular.

HOLANDA \& GUEDES (1981) também realizaram ensaios em caldas de solocimento, na obra de Tucuruí, e obtiveram um diagrama triangular semelhante àquele proposto por BARBEDETE \& SABARLY(op. cit.), conforme mostra a FIGURA 20. Ao consultar as duas publicações notou-se, além da semelhança da proposta, que os trabalhos realizados em Tucuruí, provavelmente estão fundamentados na proposta de BARBEDETE \& SABARLY (op. cit.).

Seguindo uma proposta diferente para obter parâmetros reológicos das caldas de solo-cimento, foi feito por PITTA (1984), um estudo no laboratório com as informações extraídas das caldas utilizadas na recuperação do pavimento da Via Anchieta, cuja obra foi executada entre 1969 e 1970. Ao final dos ensaios, o autor propôs uma seqüência de ensaios e atividades para dosagem da calda mais adequada para injeção, a saber:

- o primeiro ensaio proposto foi a determinação da curva granulométrica do solo componente da calda, para verificar se a curva resultante situava-se dentro dos limites estabelecidos pelo autor (FIGURA 21);

- na etapa seguinte, sugeriu a determinação do tempo de escoamento em função do teor de cimento e do conteúdo de água;

- a partir das amostras de caldas com diferentes teores de cimento, o autor realizou ensaios para medir a contração volumétrica; 
- com o resultado dos ensaios anteriores, elaborou um gráfico para determinar o conteúdo de água necessário para o teor de cimento ótimo;

- finalmente, submeteu os corpos-de-prova com diferentes teores de cimento para determinar as resistências à compressão simples.

A fluidez medida por PITTA (1984) foi feita com um cone, com $15 \mathrm{~mm}$ de diâmetro de abertura para saída da calda. Para uma dada relação de solo/cimento, o autor foi variando a quantidade de água para obter a curva de tempo de escoamento x conteúdo de água. Para determinar uma família dessa curva, que reflete a influência dos teores de água e cimento no tempo de escoamento, foi necessário repetir o ensaio para diferentes relações de solo/cimento (FIGURA 22). 


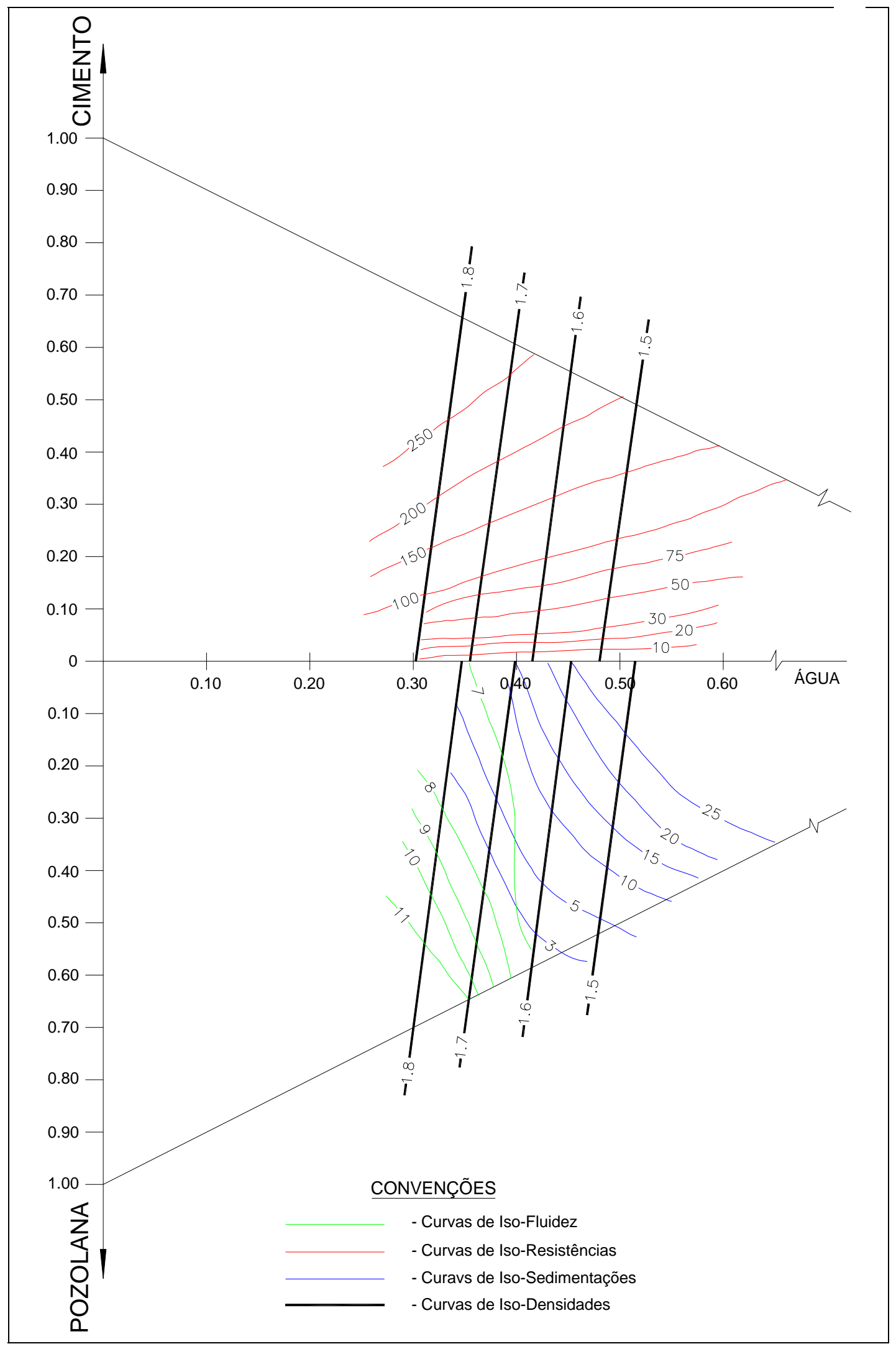

FIGURA 20 - Diagrama triangular obtido por HOLANDA \& GUEDES (1981). 


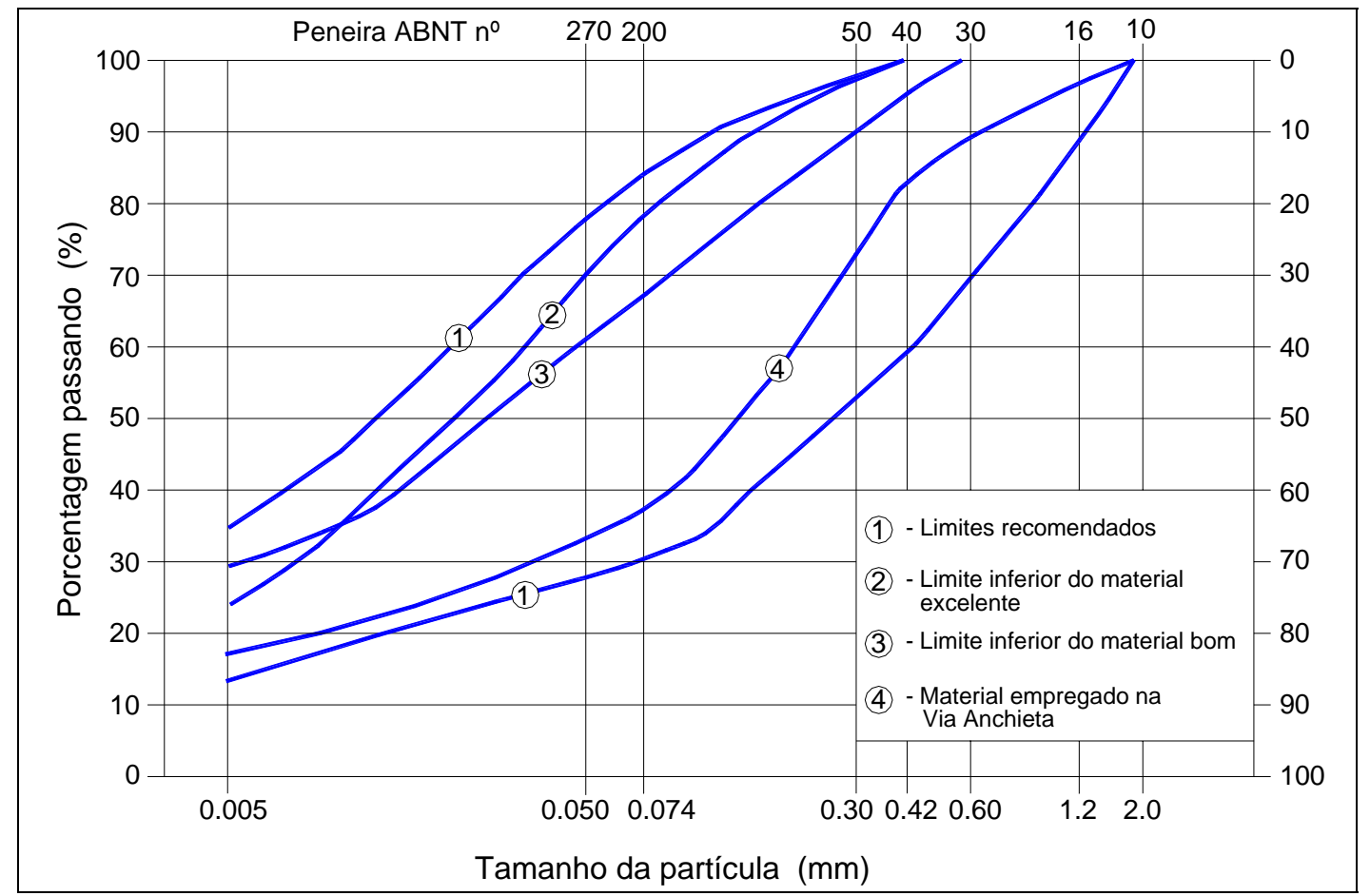

FIGURA 21 - Granulometria teórica recomendada (PITTA, 1984).

A contração volumétrica da amostra de calda de solo-cimento foi obtida pela variação volumétrica das pastilhas, em porcentagem, após ter sido submetida à secagem em forno com a temperatura entre $105^{\circ} \mathrm{C}$ e $110^{\circ} \mathrm{C}$. Esse ensaio foi realizado para diferentes traços de caldas que foram submetidas aos ensaios para a determinação da fluidez e, ao final desta etapa de ensaios, o autor obteve a curva de contração volumétrica x conteúdo de cimento, em volume (FIGURA 23). Fundamentado nos trabalhos realizados na Via Anchieta, PITTA (1984) recomendou que a contração volumétrica máxima da calda não deveria ultrapassar $10 \%$. No estudo efetuado pelo autor, para esse limite de contração volumétrica, o teor de cimento correspondente foi de 14\%, em volume (FIGURA 23). 


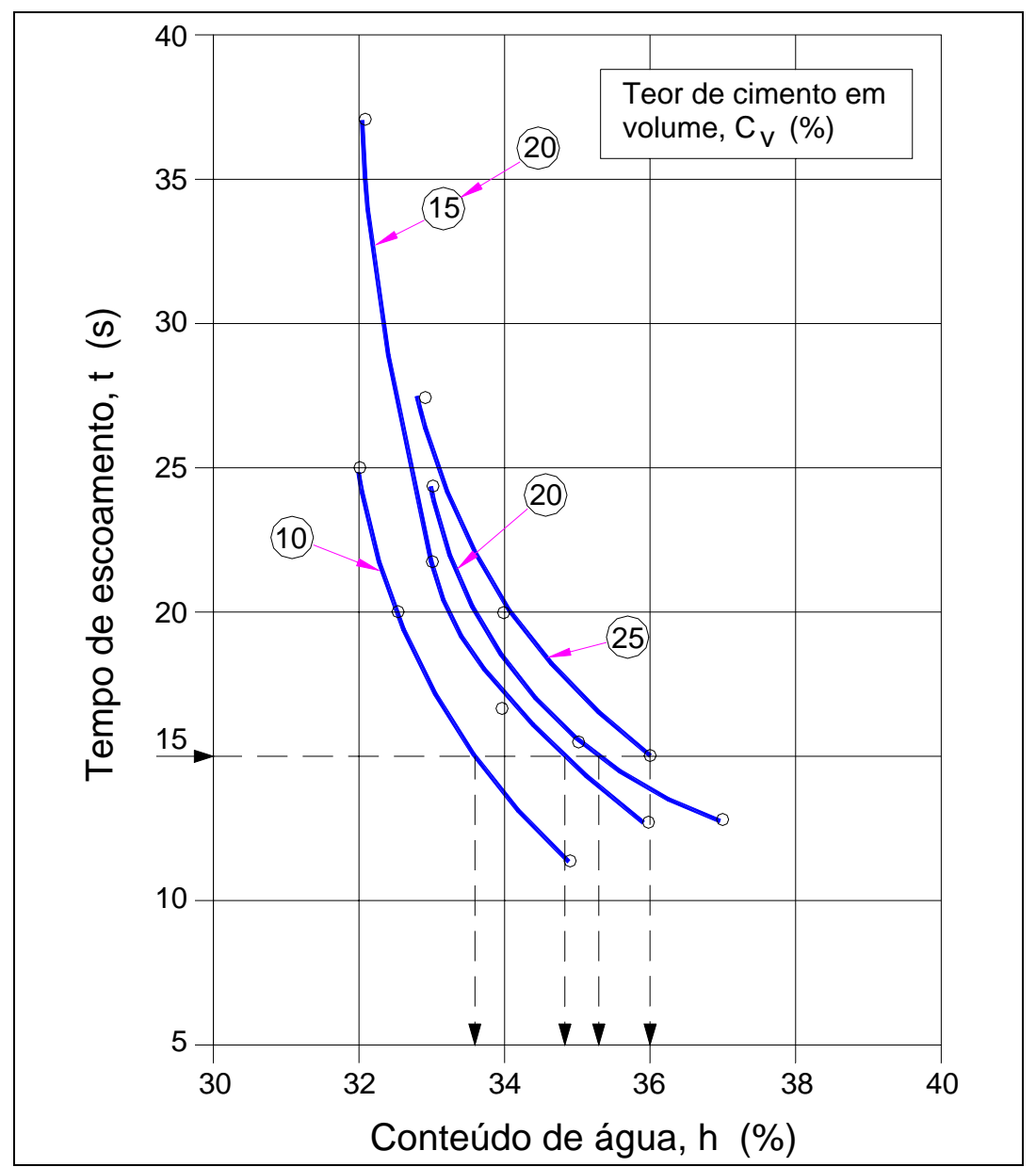

FIGURA 22 - Determinação do tempo de escoamento em função do teor de cimento e do conteúdo de água (PITTA, 1984).

Para determinar a quantidade de água necessária, levando em consideração o limite de escoamento e a contração volumétrica anteriormente determinados, PITTA (1984) traçou a curva de conteúdo de água x teor de cimento, em volume (FIGURA 24). Essa curva foi traçada a partir das informações extraídas do gráfico da FIGURA 22, considerando-se o tempo de escoamento de 15 segundos.

O conteúdo necessário para o teor de $14 \%$ de cimento (em volume) foi obtido por PITTA (op. cit.) no gráfico da FIGURA 24. Resumindo, ao final da seqüência de ensaios, foi possível ao autor estabelecer o traço da calda de solo-cimento adequado para injeções, com os seguintes parâmetros reológicos: tempo de escoamento de 15 segundos 
medido em cone com 15 mm de diâmetro na saída da calda; contração volumétrica de, no máximo, $10 \%$ e teor de cimento, em volume, de $14 \%$.

Na última etapa dos ensaios, PITTA (1984) submeteu os corpos-de-prova confeccionados com diferentes teores de cimento ao ensaio de compressão simples. Para cada conjunto de corpo-de-prova, foi determinada a resistência à compressão para as idades de 24, 72 e 168 horas.

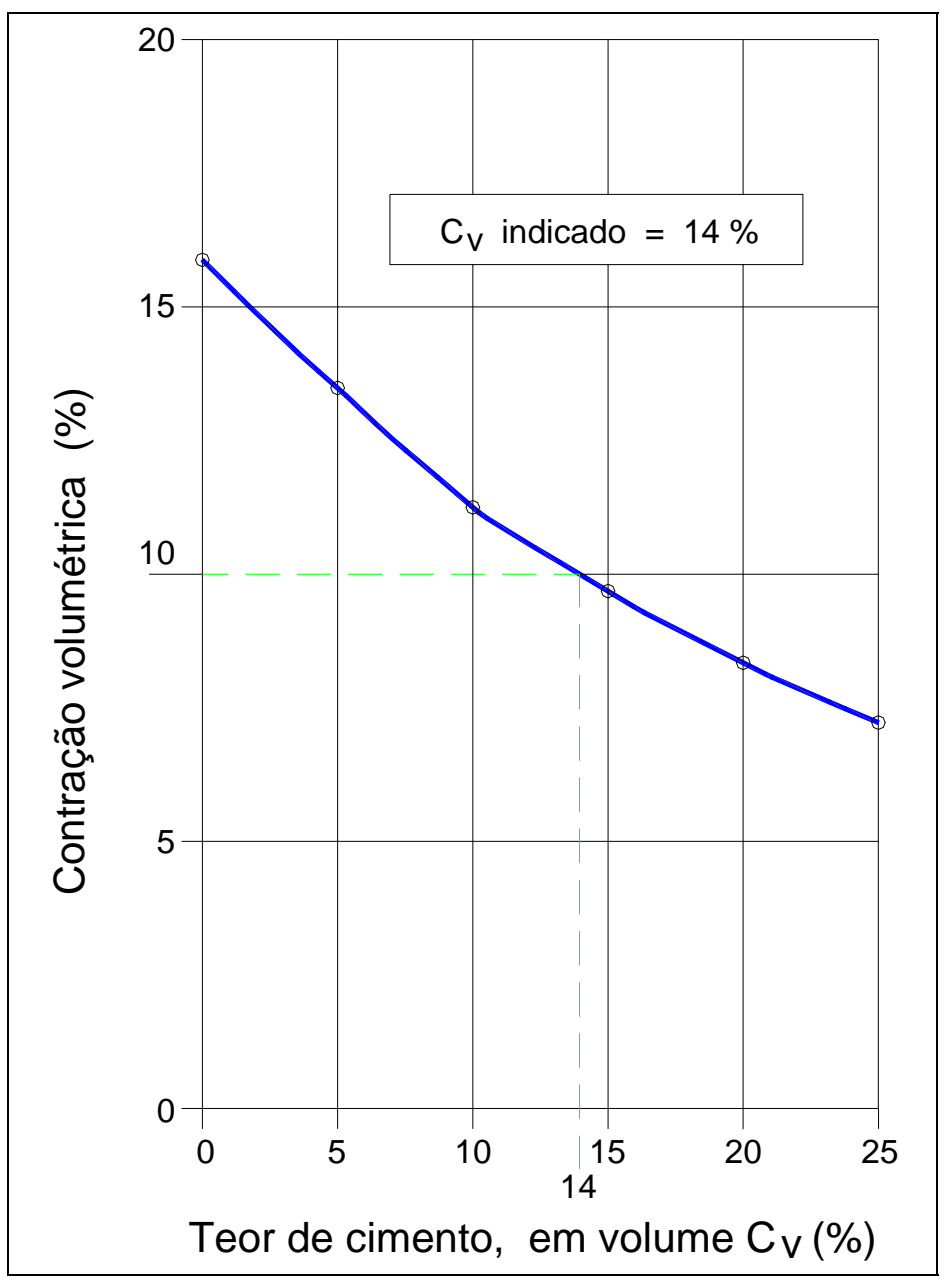

FIGURA 23 - Determinação gráfica do teor de cimento para a contração volumétrica (PITTA, 1984). 


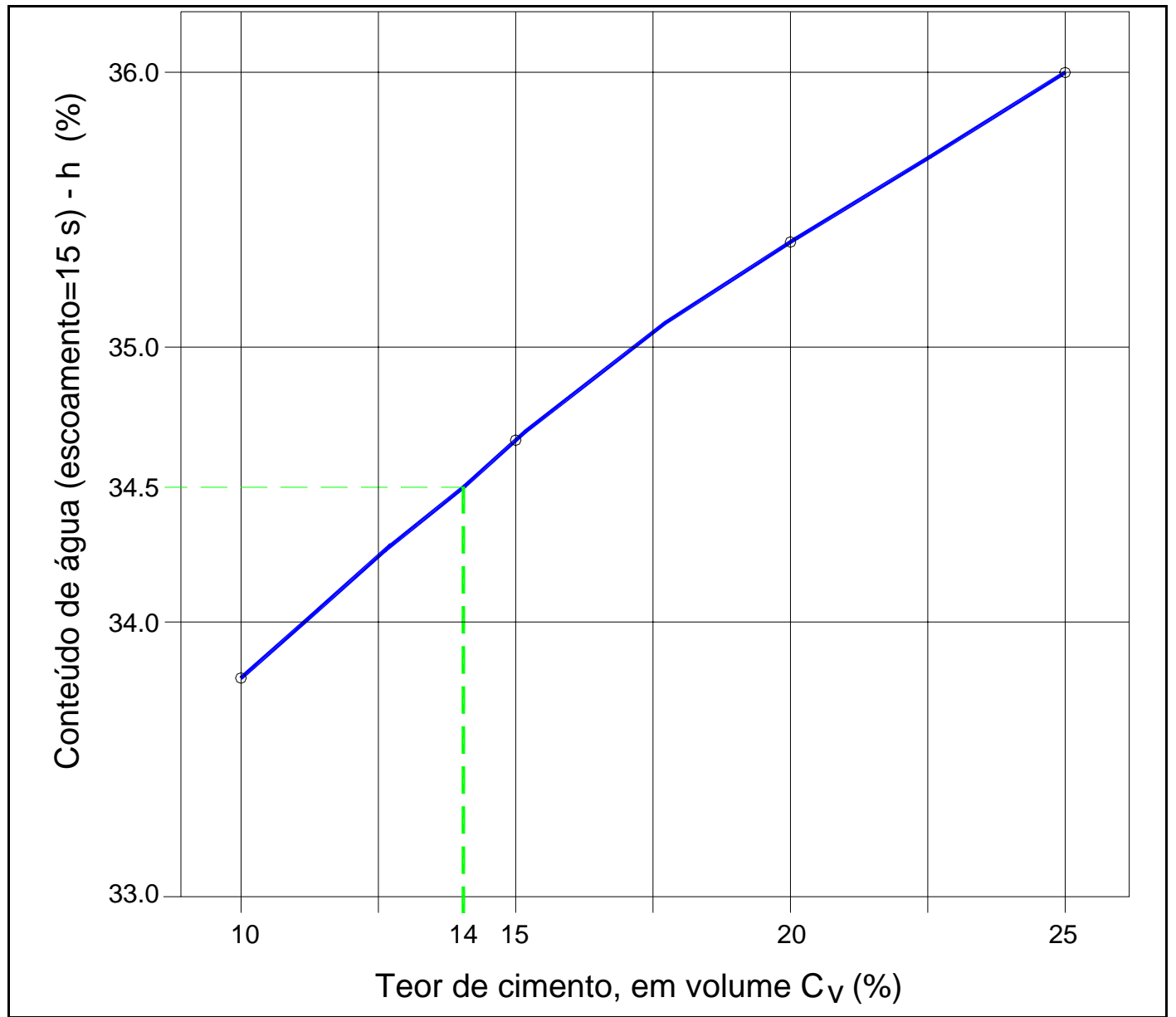

FIGURA 24 - Determinação do conteúdo de água final (h) para o teor de cimento ótimo (Cv). A curva foi traçada a partir dos dados extraídos da FIGURA 22, tomando-se como referência o tempo de escoamento de 15 segundos (PITTA, 1984).

Outra técnica para determinação das características reológicas das caldas de solo-cimento foi apresentada por BARRADAS (1985), a partir dos trabalhos realizados na Barragem de Balbina e de estudos teóricos sobre regime de escoamento das caldas de solocimento.

Para isso, o autor fez uma série de ponderações e a principal delas foi admitir que as caldas de solo-cimento, típicas do modelo Binghamiano, como sendo do tipo de Newton. 


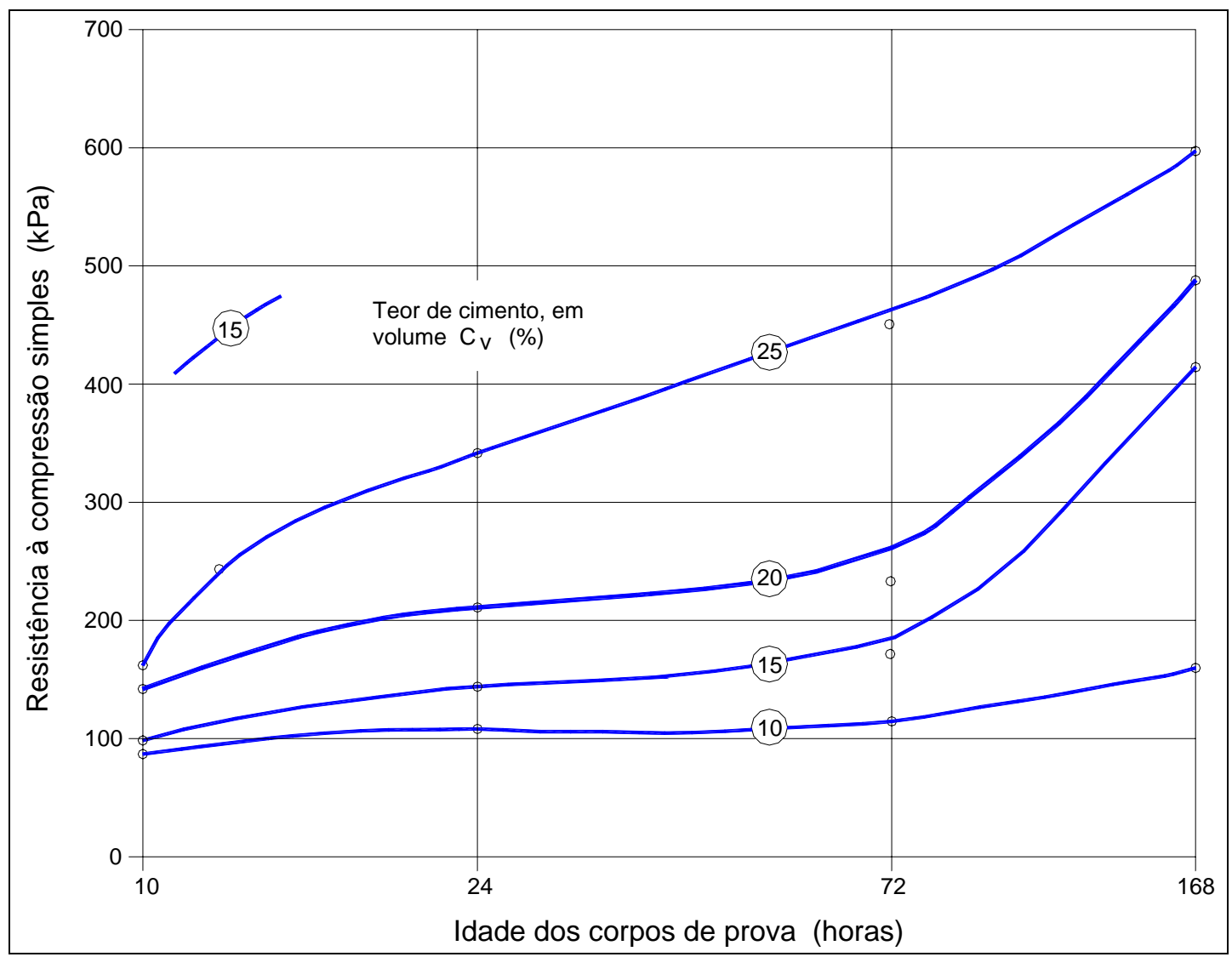

FIGURA 25 - Resistência à compressão simples da calda solidificada para diversos teores de cimento (PITTA, 1984).

Em seu trabalho, o autor afirmou que "a uma determinada taxa de cisalhamento comporta-se como fluido Newtoniano de viscosidade igual à viscosidade equivalente". Sob esta condição, BARRADAS (op. cit.) demonstrou por meio de cálculos matemáticos, que a calda de solo-cimento tem comportamento laminar. Com efeito, neste regime de escoamento a perda de carga varia linearmente com a velocidade do fluxo, tendo em vista que a tensão cisalhante varia linearmente com a perda de carga e a taxa de cisalhamento. Empregando os dados dos ensaios de perda de carga, realizados no campo durante o tratamento da fundação da Barragem de Balbina, o autor construiu o reograma da calda e, através do número de Reynolds e da densidade da calda, demonstrou a possibilidade de se obter as características reológicas das caldas de solo-cimento. 


\subsection{Pressões}

A questão da pressão de injeção ainda é um dos aspectos mais discutidos entre os técnicos, pois está relacionada diretamente com a absorção da calda. Em geral, quanto maior a pressão, maior será a penetração e, portanto, maior será a tomada de calda (INFANTI JÚNIOR \& NITTA, 1978).

Estudo sobre aplicação de pressões e absorção de caldas de cimento foi feito por SAMPAIO (1988). O autor observou variações de critérios estabelecidos nos diversos projetos de tratamentos de maciços rochosos por injeção de calda de cimento, realizados nas fundações das barragens brasileiras. Constatou que os critérios mais difundidos no meio técnico, conseqüentemente estabelecidos nos projetos, seguem a norma americana de baixas pressões, ou seja, pressão máxima de $0,23 \mathrm{kgf} / \mathrm{cm}^{2}$ (0,023 MPa) por metro de profundidade do obturador. Por outro lado, observou também exceções, como o tratamento efetuado na Barragem de Barra Bonita, onde o critério utilizado foi de altas pressões (norma européia). Nesta obra, o limite máximo para a pressão de injeção foi fixado em 1,0 kgf/cm² $(0,1 \mathrm{MPa})$ por metro de profundidade do obturador. Em outras obras, como nas barragens de Itaipu, Taquaruçu, Rosana e Nova Avanhandava, o limite estabelecido nos projetos para a pressão máxima de injeção foi de $0,5 \mathrm{kgf} / \mathrm{cm}^{2}$ por metro de profundidade do obturador (MANO \& PALAZZO NETO, 1981).

Ainda sobre as pressões de injeção no tratamento de maciços rochosos, DUARTE (1990), na tentativa de padronizar critérios e procedimentos nos trabalhos de injeção, experimentou utilizar nas obras brasileiras as recomendações do "Bureau of Reclamation" que sugerem a utilização do limite das pressões de injeção de até 0,58 atm por metro de profundidade. Ao final dos experimentos, o autor recomendou aplicar pressões mais elevadas para aumentar a eficiência das injeções, exceto nos terrenos onde existem trechos desfavoráveis à aplicação dessas pressões. Para o tratamento de maciço rochoso constituído por rocha de boa qualidade geomecânica, o autor apresentou sugestões de critério 
para cálculo do limite máximo para a pressão de injeção em função dos traços das caldas de cimento, a saber:

- $0,4 \mathrm{kgf} / \mathrm{cm}^{2}(0,04 \mathrm{MPa})$ por metro linear de profundidade para caldas de relação a:c $=1: 1$, em peso;

- $\quad 0,5 \mathrm{kgf} / \mathrm{cm}^{2}(0,05 \mathrm{MPa})$ para as caldas 0,8:1,0;

- $\quad 0,6 \mathrm{kgf} / \mathrm{cm}^{2}(0,06 \mathrm{MPa})$ para caldas $0,7: 1,0$ ou $0,6: 1,0$.

É importante notar que, na sugestão apresentada, o autor procurou aumentar gradualmente o limite da pressão à medida que o traço da calda foi se tornando mais denso. Com efeito, nessa sugestão, está inserida a sua principal preocupação em melhorar a eficiência da injeção por meio da introdução de caldas mais densas nas fraturas das rochas.

Os critérios utilizados para determinação das pressões de injeção em maciços terrosos diferem sobremaneira daqueles relatados pelos autores acima citados. Nos trabalhos de injeção em maciços terrosos, o processo inicia-se pela ruptura do solo, enquanto que nos tratamentos de maciços rochosos há limites para a pressão, exatamente para evitar a ruptura da rocha.

Avaliações dos valores dessas pressões de ruptura dos solos foram feitas por SANTOS et al. (1985), a partir dos dados obtidos no tratamento efetuado na fundação da barragem de terra de Balbina. Ao realizarem análise das pressões aplicadas, os autores verificaram que os valores ficaram entre $0,5 \mathrm{kgf} / \mathrm{cm}^{2}$ (0,05 MPa) e 3,5 kgf/cm ${ }^{2}$ (0,35 MPa), com maior freqüência entre 0,5 e 2,0 kgf/ $\mathrm{cm}^{2}$ (0,2 MPa). Além disso, realizaram a análise do comportamento da pressão aplicada desde a ruptura da bainha até a injeção da calda na fratura induzida. Os autores verificaram que, ao longo do tempo, a pressão crescia até atingir o valor máximo quando ocorria a ruptura da bainha e do maciço (FIGURA 26). Nos casos das bainhas que possuíam resistência mecânica superior ao do maciço terroso, a pressão aplicada decrescia e mantinha-se constante durante a injeção da calda (FIGURAS 26a e 26b). 
Os autores observaram ainda ligeira descompressão na pressão aplicada (FIGURA 26a) sem encontrar justificativa técnica desse comportamento.

Em algumas situações, SANTOS et al. (1985) perceberam que não ocorria o decaimento da pressão aplicada após a ruptura do maciço, e além disso notaram que a pressão de injeção se igualava ao da ruptura e se mantinha constante durante o preenchimento da fratura (FIGURA 26c). Verificaram que esse comportamento da pressão se configurava quando a bainha apresentava resistência inferior ao do maciço de solo ou quando a bainha não envolvia totalmente a válvula-manchete.

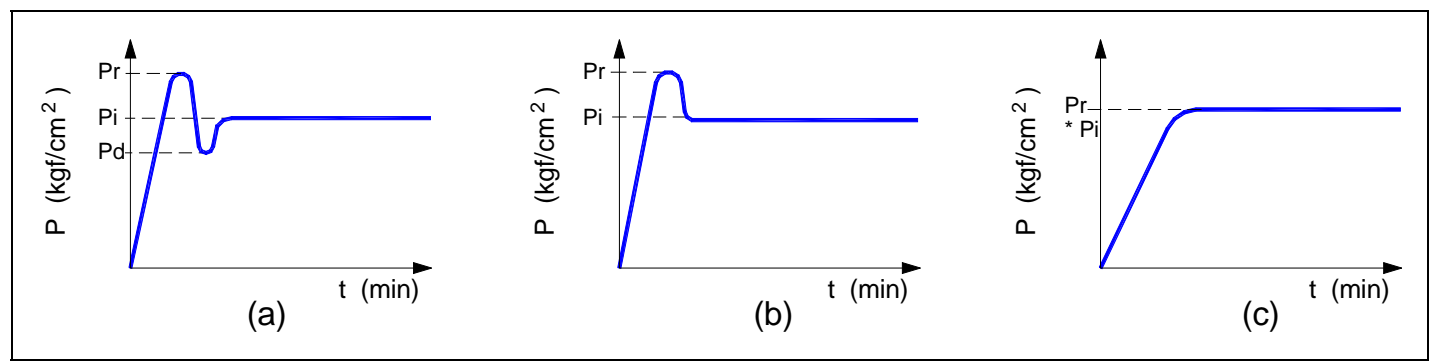

onde: $\mathrm{Pr}$ = pressão de ruptura da bainha; $\mathrm{Pi}$ = pressão de injeção e Pd = pressão de descompressão

FIGURA 26 - Valores relativos das pressões no tratamento efetuado em Balbina: a) e b) para bainhas mais resistentes que o solo e c) bainha com resistência menor ou semelhante ao do solo (SANTOS et al., 1985).

Outro aspecto relacionado com a pressão de injeção foi analisado por OLIVEIRA \& FERREIRA (1982), que estudaram a elevação da pressão de injeção em decorrência de sucessivas fases do tratamento. Os estudos desenvolvidos pelos autores foram fundamentados nos trabalhos de consolidação de depósito sedimentar da Bacia de São Paulo.

Novos estudos sobre elevações nas pressões de injeção também foram desenvolvidos por GUIMARÃES FILHO (1984) durante os trabalhos de tratamento com injeção de calda de cimento de um depósito aluvionar (FIGURA 27). O objetivo desse tratamento foi consolidar a camada de sedimento mole para abrigar parte de um túnel na cidade de São Paulo, pertencente à Companhia do Metropolitano - Metrô. O autor utilizou também informações extraídas do tratamento efetuado nas fundações de edifícios, na cidade 
de Santos, onde a consolidação do terreno foi conseguida por meio de campanhas sucessivas de injeções. O maciço terroso, produto de alteração da rocha do embasamento que recebeu as injeções, era constituído por areia fina argilosa, micácea, medianamente compacta, de cores cinza e amarela. A FIGURA 28 mostra os acréscimos verificados na pressão quando a injeção passou da primeira para a segunda fase e desta para a terceira.

MOREIRA et al. (1990) também observaram, na fase final dos trabalhos de injeção realizados na obra de Balbina, acréscimos na pressão após sucessivas fases de injeção, atingindo valores de até 1,5 vezes o valor inicial.

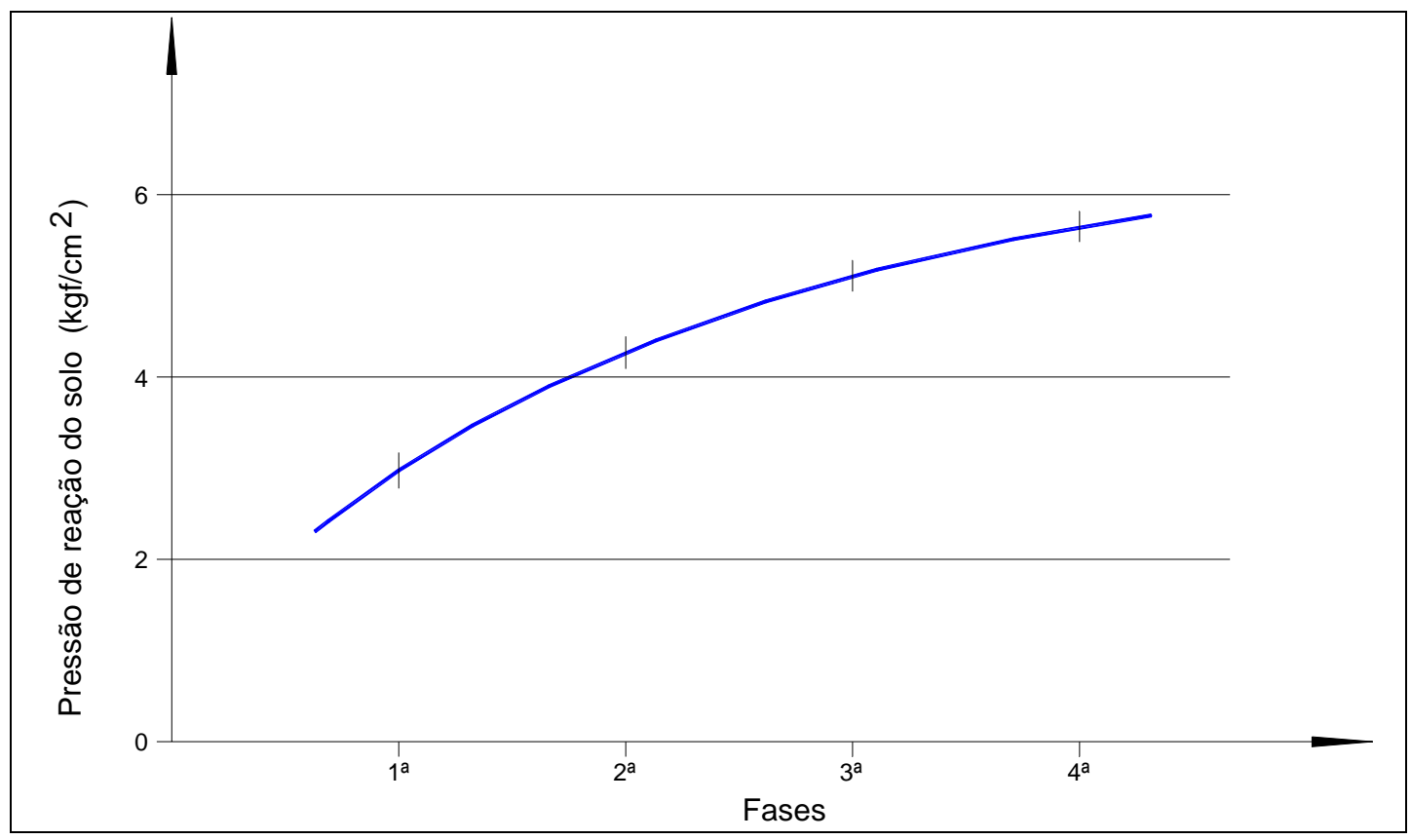

FIGURA 27 - Aumento médio da pressão em função das fases de injeção no tratamento de depósito aluvionar, constituído por sedimento mole, para escavação de túnel urbano, na cidade de São Paulo (GUIMARÃES FILHO, 1984). 


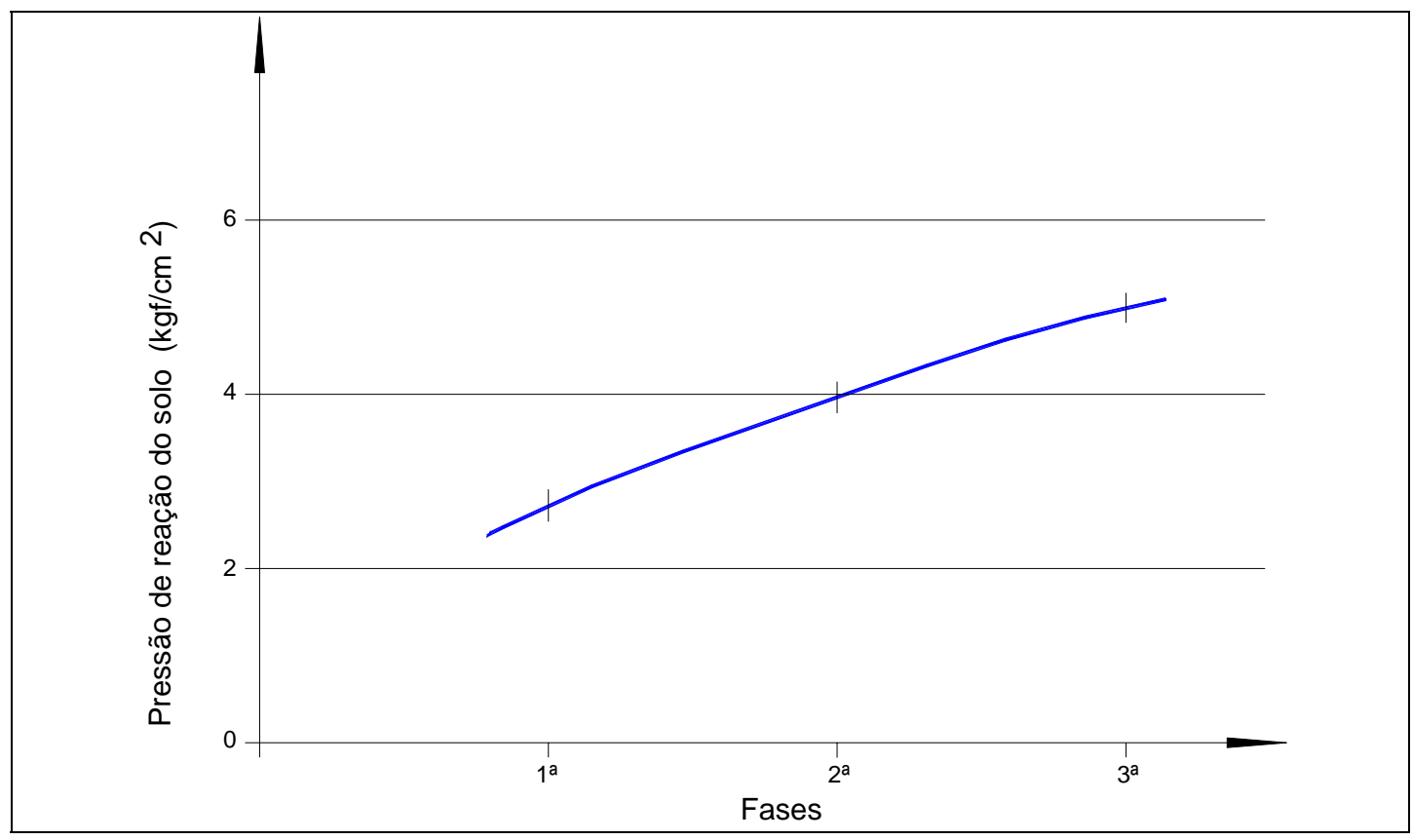

FIGURA 28 - Aumento médio da pressão em função das fases de injeção para tratamento do maciço de fundação de edifícios, composto por solo residual do embasamento (GUIMARÃES FILHO, 1984).

\subsection{Avaliação da eficiência}

Após a campanha de injeção, são realizados ensaios de campo para, principalmente, avaliar a eficiência do serviço executado. Tanto em maciço rochoso como no terroso, é comum a execução de ensaios em furos de sondagens para determinar o coeficiente de permeabilidade antes e depois do tratamento.

Nos maciços rochosos, são realizados ensaios do tipo perda d’água sob pressão (ABGE, 1975), que consiste em determinar a absorção das estruturas permeáveis da rocha, por unidade linear de profundidade, quando se introduz um volume conhecido de água sob determinada pressão.

Por outro lado, no maciço terroso, os ensaios de permeabilidade em furos de sondagens são conhecidos, de forma genérica, como "ensaios de infiltração". Como estes ensaios não utilizam sistema para observar possíveis variações das cargas piezométricas, também são conhecidos como "ensaios pontuais”. 
Os ensaios geofísicos, do tipo crosshole, além de sua aplicação nas campanhas de investigações geológico-geotécnicas, também podem ser utilizados para avaliar a eficiência dos tratamentos de maciços. Trata-se de uma técnica, cuja aplicação nos terrenos brasileiros ainda é muito restrita, mesmo nos trabalhos de levantamento geológicogeotécnico. A aplicação pioneira dessa técnica geofísica para avaliar a eficiência do tratamento de maciço terroso foi no estudo desenvolvido no campo de prova da Usina de Rasgão. A técnica geofísica aplicada e os critérios utilizados foram registrados por PRADO et al. (1989).

No presente trabalho, foram analisados os resultados obtidos no campo de prova, onde foram executados levantamentos geofísicos, do tipo crosshole, antes e após o tratamento com injeção de solo-cimento.

\subsubsection{Ensaios de permeabilidade}

Os ensaios para determinação do coeficiente de permeabilidade em solo podem ser separados em dois grupos, conforme o método de execução: nível constante e nível variável. Estes grupos ainda podem ser subdivididos, de acordo com o diferencial de pressão aplicada no furo ou poço e são classificados em: carga e descarga. A TABELA 2 mostra a denominação dos ensaios propostos pela ABGE (1981) e o método utilizado na prospecção do terreno.

TABELA 2 - Classificação dos ensaios de permeabilidade em solo (ABGE, 1981).

\begin{tabular}{c|c|c|c}
\hline Maneira de realização & $\begin{array}{c}\text { Pressão } \\
\text { aplicada }\end{array}$ & $\begin{array}{c}\text { Denominação dos } \\
\text { ensaios }\end{array}$ & $\begin{array}{c}\text { Método de } \\
\text { prospecção }\end{array}$ \\
\hline \multirow{2}{*}{ Nível constante } & Carga & Infiltração & $\begin{array}{c}\text { Sondagens, poços e } \\
\text { cavas }\end{array}$ \\
\cline { 2 - 4 } & Descarga & Bombeamento & Poços e sondagens \\
\hline \multirow{2}{*}{ Nível variável } & Carga & Rebaixamento & Poços e sondagens \\
\cline { 2 - 4 } & Descarga & Recuperação & Poços e sondagens \\
\hline
\end{tabular}


O nível constante ou variável refere-se à posição da superfície d’água, em poços, furos de sondagens ou trincheiras, durante a execução dos ensaios. A sua manutenção numa determinada cota pode ser conseguida através da introdução de água (ensaio de infiltração) ou retirando-a por meio de bombeamento (ensaio de bombeamento). Nos dois casos, mede-se a vazão de água injetada ou extraída, mantendo-se a carga constante.

Nos ensaios de nível variável, altera-se sua posição natural através de introdução de água (ensaio de rebaixamento) ou retirada (ensaio de recuperação). Nestes tipos de ensaios, mede-se a velocidade de rebaixamento ou de recuperação do nível d’água.

Existe um outro tipo de ensaio de permeabilidade de nível variável, denominado slug test, que requer a instalação de transdutores de pressão para acompanhar a estabilização do nível d’água, cuja variação é provocada pela aplicação de uma carga ou descarga instantânea (COOPER et al. 1967). Devido à necessidade de utilizar estes transdutores, a execução desse tipo de ensaio não é comum no Brasil.

A prática dos ensaios de permeabilidade, bem como a escolha do tipo, os equipamentos necessários e o método de cálculo foram apresentados no Boletim número 4 da ABGE (1981).

Para determinar o coeficiente de permeabilidade a baixas profundidades em terrenos constituídos por solos, é comum a execução do ensaio denominado Matsuo (ABGE, 1981). Trata-se de um ensaio simples, executado em cava regular e padronizada, de forma trapezoidal e de pequena profundidade. O ensaio é executado em duas etapas: a primeira em cava menor, e a segunda, após sua ampliação. Nas duas etapas de ensaios, medem-se as absorções por tempo até que a vazão de infiltração se mantenha constante. Ao mesmo tempo, mede-se também a evaporação no local do ensaio, empregando-se um recipiente de área conhecida. Esse valor deve ser subtraído do volume de água empregado no ensaio para determinar a vazão efetiva de água infiltrada no terreno. 
Detalhes e método de cálculo deste ensaio podem ser obtidos no Boletim da ABGE (1981).

\subsubsection{Ensaios geofísicos}

A injeção de calda de cimento ou de solo-cimento nos maciços tem como resultado o aumento de sua resistência e/ou a diminuição da permeabilidade, que se conseguem pelo preenchimento dos espaços vazios, como das fraturas naturais de maciços rochosos ou daquelas abertas pelo processo do fraturamento hidráulico. Esse preenchimento, por sua vez, é responsável diretamente por efeitos que proporcionam alterações na propagação das ondas sísmicas.

Os fatores que influenciam na velocidade de propagação das ondas sísmicas, resumidamente, são: litologia, granulometria, densidade, anisotropia, porosidade, pressão de confinamento, temperatura, saturação e propriedades dos fluidos contidos nos poros.

Vários experimentos com meios porosos naturais e sintéticos foram feitos por WYLIE et al. (1956), em laboratório. Nesses experimentos, os autores buscavam uma fórmula empírica que relacionasse a velocidade da onda primária P (onda longitudinal, cuja direção de vibração das partículas possui a mesma direção de propagação) com a porosidade do meio. Ao concluírem a pesquisa, demonstraram que os arenitos saturados e sujeitos a várias pressões de confinamento, a velocidade da onda $\mathrm{P}$ relacionava-se com a porosidade através da seguinte relação:

$$
\frac{1}{V p}=\frac{\phi}{V w}+\frac{1-\phi}{V m}
$$

onde:

$\phi=$ porosidade; 


$$
\begin{aligned}
& V p=\text { velocidade da onda } \mathrm{P} \text { medida; } \\
& V m=\text { velocidade da onda } \mathrm{P} \text { na matriz; } \\
& V w=\text { velocidade da onda } \mathrm{P} \text { na água. }
\end{aligned}
$$

Como os valores de $V m$ e $V w$ são constantes e determináveis, pode-se fixá-los e, assim, a única variável será o parâmetro porosidade $(\phi)$.

Entretanto, nessa relação apresentada por WYLIE et al. (op. cit.) não foi contemplada a influência que a velocidade de propagação das ondas P sofre com as variações da mineralogia, da geometria dos poros, do grau de consolidação, da cimentação, da pressão de confinamento, etc. Vale destacar que as ondas sísmicas do tipo P são rápidas, sendo, portanto, as primeiras a serem detectadas após um abalo sísmico.

A análise da influência dos fatores acima citados levou outros autores a estabelecer novas fórmulas empíricas, como de RAYMER et al. (apud PRADO, 1994) que, baseados em dados de perfilagem sísmica, estabeleceram a relação:

$$
V p=(1-\phi)^{2} V m+\phi V f
$$

onde:

$V f$ = velocidade da onda P no fluido.

PICKETT apud DOMENICO (1984) propôs que a relação da velocidade da onda primária P ou secundária S (onda transversal ou de cisalhamento) fosse feita com base nas propriedades do tipo litológico. O parâmetro $\boldsymbol{A}$ da fórmula é determinado principalmente pela velocidade da matriz $\left(1 / \mathrm{V}_{\mathrm{m}}\right)$ e o $\boldsymbol{B}$ por outras propriedades, como consolidação, geometria dos poros e pressão diferencial (diferença entre a pressão geoestática e a intersticial). Desta maneira, o autor estabeleceu que: 
$\frac{1}{V}=A+B \phi$

onde:

$V=$ velocidade da onda $\mathrm{P}$ ou da onda $\mathrm{S}$.

Um aspecto interessante dessa relação diz respeito à utilização também das velocidades das ondas $S\left(V_{s}\right)$, uma vez que ela se propaga somente pela porção sólida do meio, não sofrendo alterações significativas pela variação do grau de saturação do meio, ao contrário das ondas $\mathrm{P}$, onde o aumento da saturação em água aumenta a velocidade de propagação. É interessante destacar que as ondas $\mathrm{S}$ são do tipo transversal ou de cisalhamento, cuja direção de vibração das partículas é perpendicular à direção de propagação das ondas.

Dentro desta linha de pesquisa, várias foram as tentativas, apresentadas por diversos autores, de caracterizar os maciços empregando-se as velocidades de ondas sísmicas. ONODERA (apud TURK \& DEARMAN, 1987) definiu a razão de velocidade da onda P como índice de qualidade do maciço, obtida pela velocidade medida em laboratório sobre amostras intactas submetidas a esforços equivalentes aos in situ e com as mesmas condições de conteúdo em ar ou água, comparados com as velocidades medidas no campo.

TURK \& DEARMAN (op. cit.) definiram o índice sísmico de fissuras K (seismic fissuration index), que é a razão da diferença das velocidades das ondas $\mathrm{P}$ ou $\mathrm{S}$ obtida quando uma amostra seca é testada sob uma carga igual ao esforço compressivo uniaxial $\left(\mathrm{V}_{0}\right)$ e sem a aplicação da carga $\left(V_{d}\right)$.

$$
K=\frac{V_{0}-V_{d}}{V_{d}}
$$


Os mesmos autores, utilizando-se de uma série de medidas de velocidade da onda P, obtidas por outros pesquisadores em ensaios de campo e de laboratório, e aplicando a equação da velocidade média, obtiveram uma boa correlação entre o que chamaram field seismic fracture index $(\mathrm{F})$ e a velocidade de campo da onda $\mathrm{P}$.

Com o objetivo de verificar a eficiência de um tratamento, por exemplo com injeção de calda de cimento em maciços rochosos, os autores acrescentaram à fórmula a parcela da velocidade relativa ao material injetado. Assim, supondo que todos os poros e fraturas tenham sido preenchidos pelo material injetado, a equação do tempo médio pode ser dada por:

$$
\frac{1}{V_{f}}=\frac{1-F}{V_{0}}+\frac{F}{V_{g}}
$$

onde:

$V_{f}=$ velocidade obtida no campo;

$V_{0}=$ velocidade da rocha sã à pressão igual à profundidade do maciço $(5,546$ $\mathrm{km} / \mathrm{s}$;

$V_{g}=$ velocidade do material injetado $(2,4 \mathrm{~km} / \mathrm{s})$;

$F=$ field seismic fracture index.

Ao assumirem que o preenchimento dos poros, juntas e fraturas pelo material de injeção tenha ocorrido em diferentes proporções, como 25\%, 50\% e 75\%, a equação anterior foi modificada para:

$$
\frac{1}{V_{f}}=\left(\frac{1-F}{V_{0}}\right)+F\left(\frac{1-\omega}{V_{w}}\right)+\left(\frac{2 F}{V_{g}}\right)
$$


onde:

$\omega$ = porcentagem de injeção.

Sintetizando, pode-se afirmar que existem boas correlações entre os valores de velocidade de propagação de ondas sísmicas e os parâmetros dos maciços diretamente afetados pelos processos de injeção, tais como a porosidade e a permeabilidade.

O ensaio crosshole consiste em gerar ondas sísmicas em um furo e receptá-las em um ou mais furos adjacentes, de forma que tanto a fonte como os receptadores devem estar na mesma cota de investigação. Isto se deve à necessidade em obter valores reais das velocidades de propagação das ondas P e S, que são utilizados na determinação do módulo de elasticidade dinâmico de maciços e na identificação de eventuais anomalias existentes entre os furos ensaiados, como, vazios, faixas mais intensamente alteradas, etc. (DOURADO 1984 \& DOURADO et al., 1994).

PRADO (1994) estabeleceu critérios para programação e execução dos ensaios crosshole. Para conhecimento do perfil do subsolo, propôs que fossem aproveitados os furos utilizados nos ensaios para amostrá-los. Após a perfuração, o autor recomenda revesti-los com PVC, cuja extremidade inferior deve ser tamponada e de diâmetro interno compatível com as dimensões dos equipamentos utilizados para a execução dos ensaios. Recomendou, ainda, preencher o espaço anelar existente entre o revestimento e a parede dos furos com calda de cimento para permitir um bom acoplamento mecânico.

Quanto ao espaçamento entre furos, afirmou que também é fator fundamental, pois o aumento da resistência do solo com a profundidade pode permitir a chegada antecipada de ondas refratadas em horizontes mais rígidos, induzindo a determinação de velocidades aparentes e, portanto, não reais dos níveis ensaiados (FIGURA 29). Foi sugerido por PRADO (1994), em maciços terrosos, espaçamento entre furos de 2 a 6 m no máximo. 


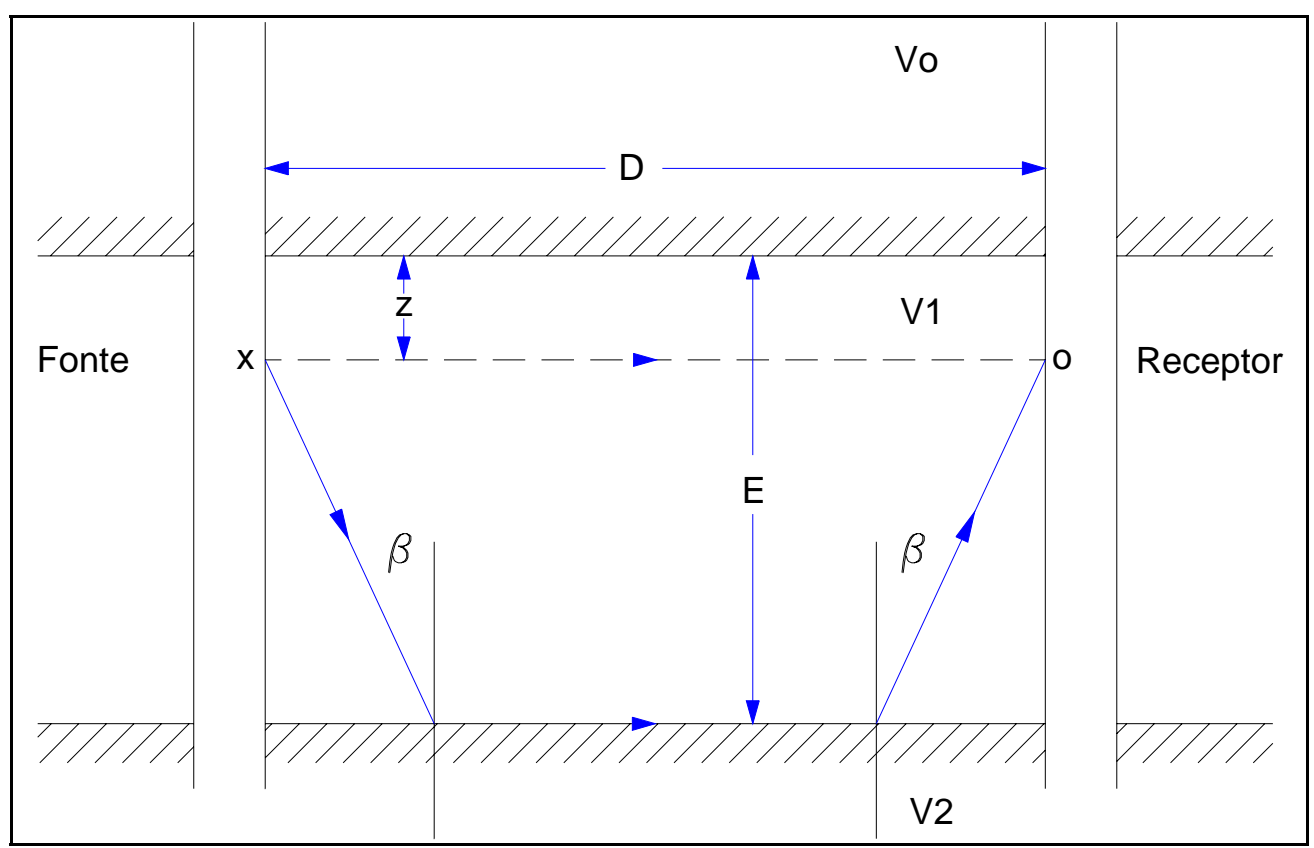

FIGURA 29 - Determinação de velocidade num estrato sísmico. A fonte de energia (F) e o receptor (R) localizam-se no estrato intermediário (PRADO, 1994).

Para obter informações sobre critérios para programação e execução dos ensaios crosshole, bem como a escolha dos equipamentos de registro, tipos de fontes geradoras de ondas sísmicas, sistema de gatilhamento, calibração e análise de sismogramas, recomenda-se a leitura da dissertação de mestrado de PRADO (op. cit.).

A técnica do ensaio sísmico crosshole tem sido utilizada, principalmente, para caracterização de módulos elásticos dinâmicos de maciços rochosos e terrosos, através da determinação dos valores de velocidade de propagação de ondas compressionais e cisalhantes in situ (IPT, 1989).

Os princípios teóricos dos parâmetros elásticos dos materiais e as técnicas sísmicas mais usuais para sua determinação podem ser vistos em DOURADO (1984).

O autor mostrou que a associação das velocidades sísmicas com os parâmetros elásticos dos materiais está fundamentada no princípio da lei de Hooke, ou seja, quando o esforço não é suficientemente elevado para vencer o limite elástico de um material, a sua 
deformação é diretamente proporcional ao esforço que a produziu. Nesta situação, os parâmetros elásticos de um material são definidos e avaliados pelas seguintes constantes:

Módulo de Young (E): é definido como sendo a relação entre o esforço unitário (força aplicada por unidade de área) e a deformação longitudinal unitária.

Coeficiente de Poisson ( $\delta$ ): é a relação entre as deformações transversal unitária e a longitudinal unitária.

Módulo de Compressibilidade (K): é a relação entre a variação de pressão e a variação unitária de volume.

Módulo de Rigidez (G): é a relação entre o esforço transversal unitário e o deslocamento relativo dos planos de deslizamento.

De acordo com o autor, as relações das velocidades das ondas P e S com os parâmetros elásticos e densidade dos materiais são as seguintes:

$$
\begin{aligned}
& V p=\sqrt{\frac{E(1-\delta)}{(1-2 \delta)(1+\delta)}} \\
& \mathrm{Vp}=\sqrt{\frac{\mathrm{K}+\frac{4}{3} \mathrm{G}}{\rho}} \\
& V s=\sqrt{\frac{E}{\rho} \frac{1}{2(1+\delta)}} \\
& V s=\sqrt{\frac{G}{\rho}}
\end{aligned}
$$


onde:

$V p$ = velocidade de propagação das ondas compressionais;

Vs = velocidade de propagação das ondas cisalhantes;

$E$ = Módulo de Young;

$K$ = Módulo de Compressibilidade;

$G$ = Módulo de Rigidez;

$\delta=$ Coeficiente de Poisson;

$\rho=$ Densidade do material.

A partir da relação das eq.(31) e eq.(33), DOURADO (1984) obteve o coeficiente de Poisson dinâmico, definido pela relação:

$$
\delta=\frac{\left(\frac{V p}{V s}\right)^{2}-2}{2\left(\frac{V p}{V s}\right)^{2}-2}
$$

Da eq.(31), obteve ainda o Módulo de Young dinâmico:

$$
E=\frac{V p^{2} \rho(1-2 \delta)(1+\delta)}{(1-\delta)}
$$

A partir da eq.(34), relacionou a velocidade de propagação das ondas cisalhantes e o Módulo de Rigidez:

$$
G=\rho V s^{2}
$$


E das eq.(32) e eq.(34), mostrou a possibilidade de se obter o Módulo de Compressibilidade Dinâmico:

$$
K=\rho V p^{2}-\left(\frac{4}{3} \rho V s^{2}\right)
$$

DOURADO (1984) afirmou ainda que o termo dinâmico utilizado nos parâmetros elásticos determinados pela sísmica foi empregado para diferenciar daqueles que são obtidos por meio dos ensaios estáticos. Confirmou também, experimentalmente, que os valores dinâmicos são maiores que os estáticos e que esta diferença aumenta em materiais com menores valores de Módulo de Elasticidade. 


\section{INJEÇÕES DE SOLO-CIMENTO EXECUTADAS EM OUTRAS OBRAS BRASILEIRAS}

Neste capítulo, foram apresentadas as atividades relativas à injeção de calda de solo-cimento realizadas nas obras da Barragem de Balbina e da Cooperativa Central de Laticínios do Estado de São Paulo, extraídas de publicações e de relatórios técnicos. Os resultados das análises das informações técnicas obtidas nestas obras serviram para subsidiar o estudo realizado a partir dos dados da Usina de Rasgão.

Foram apresentadas também algumas considerações sobre as injeções de solocimento executadas na Usina de Rasgão, na qual o autor deste trabalho teve participação efetiva no tratamento e nos ensaios durante o período de 1986 a 1988. As atividades executadas nesta obra são descritas detalhadamente no capítulo seguinte.

Nas obras acima citadas, a aplicação da técnica de injeção de calda de solocimento visou dois objetivos distintos, a saber:

- impermeabilização ou vedação: para reduzir a permeabilidade dos maciços terrosos das fundações da Barragem de Balbina e da tomada d'água da Usina de Rasgão, foram construídas cortinas, através de injeções de solocimento em furos de sondagens;

- consolidação: para melhoria da qualidade dos maciços das fundações da casa de força da Usina de Rasgão e dos edifícios do laboratório da Cooperativa de Laticínios, recorreu-se, também, à técnica da injeção de solo-cimento.

A seguir, para as obras de Balbina e da Cooperativa de Laticínios, foram descritas a localização dos empreendimentos, os aspectos geológico-geotécnicos dos terrenos, os métodos empregados nos tratamentos, assim como os principais critérios adotados nas injeções.

\subsection{Barragem de Balbina}


As investigações preliminares realizadas nos materiais de fundação da Barragem de Balbina, localizada no Rio Uatumã, AM (FIGURA 30), de propriedade da empresa Centrais Elétricas do Norte do Brasil S.A. - ELETRONORTE, indicaram altas permeabilidades, que foram, inicialmente, negligenciadas pela equipe técnica devido à suspeita de erros na execução dos ensaios de campo. Todavia, ao verificar jorro de água durante a fase de escavação para construção da ensecadeira da margem direita, foi decidido executar uma campanha de investigação na fundação, com abertura de poços e trincheiras, nos quais observou-se a existência de canalículos com diâmetro variável de até $30 \mathrm{~mm}$. Os resultados dos ensaios de permeabilidade do tipo Matsuo (ver item 3.8.1 e ABGE, 1981), realizados no terreno de fundação da barragem, mostraram a necessidade de um tratamento vertical de impermeabilização.

Após análise de todos os dados obtidos, desde os mapeamentos, testes de permeabilidade e até os ensaios de injeção com caldas de cimento e solo-cimento, a equipe técnica optou pela construção de uma cortina de vedação constituída por uma série de furos verticais, organizados e dispostos em linhas seqüenciais de injeção. Decidiu-se, ainda, injetar caldas de solo-cimento, empregando-se válvulas do tipo manchete.

\subsubsection{Síntese dos aspectos geológico-geotécnicos}

O maciço rochoso na região próxima ao leito do Rio Uatumã é constituído por rochas vulcânicas pertencentes ao Super Grupo Uatumã. O topo rochoso apresenta irregularidade acentuada, e o maciço, quando intacto, é pouco fraturado e apresenta baixo coeficiente de permeabilidade $\left(10^{-5} \mathrm{~cm} / \mathrm{s}\right)$. Exceção se faz na região junto à superfície do topo rochoso, onde existe uma faixa de rocha alterada e muito fraturada, com espessura de até 12 m (BUOSI \& CADMAN, 1984; SIQUEIRA et al., 1986).

Sobre as rochas, aparece uma camada de solo silto-argiloso pouco arenoso, apresentando índice de resistência à penetração de média a alta compacidade (10 a 30 
golpes), verificada nos ensaios SPT - Standard Penetration Test. A espessura é variável, desde poucos metros até $15 \mathrm{~m}$ e o coeficiente de permeabilidade é relativamente baixo $\left(10^{-4}\right.$ cm/s), porém apresenta porções com valores elevados, devido à ocorrência de canalículos.

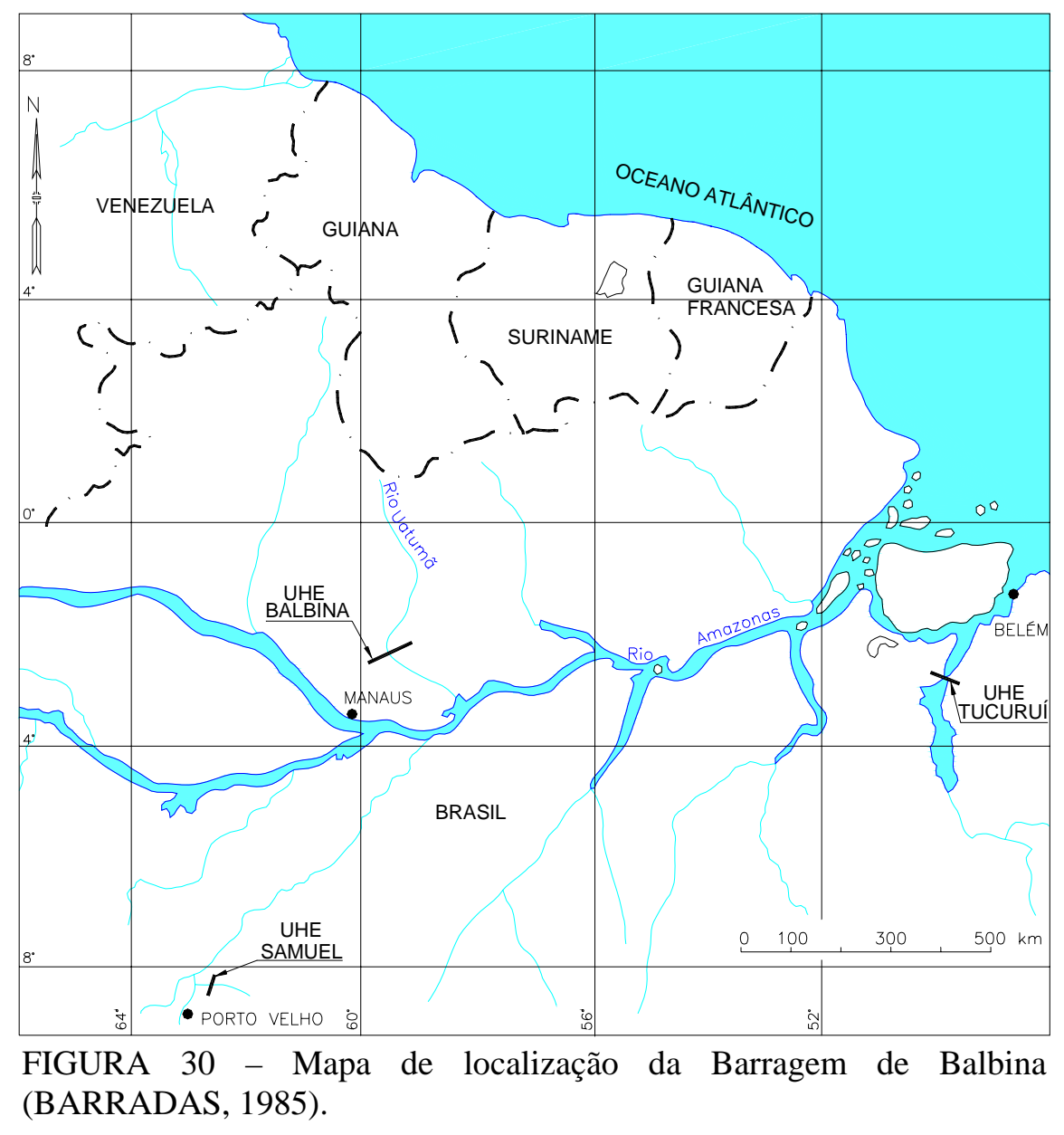

Nas áreas mais elevadas, são encontrados sedimentos do Grupo Urupadi, constituídos por camadas de areias finas intercaladas com horizontes silto-argilosos.

Na região da várzea, as camadas de sedimentos superficiais são compostas por dois tipos distintos de depósitos: o aluvionar antigo e o recente. O primeiro situa-se em cotas mais elevadas que o segundo e é composto, essencialmente, de areia com granulometria variada. Os depósitos mais recentes são constituídos por camadas de argila arenosa e de areia limpa, e ocorrem sobrepostos, ora ao maciço rochoso, ora ao solo residual (BUOSI \& CADMAN, 1984). 
Nas encostas, aparece o solo coluvionar, formado por areia fina siltosa, que recobre os sedimentos arenosos e os solos residuais.

\subsubsection{Problemas geológico-geotécnicos encontrados}

A campanha preliminar de investigação realizada por meio de sondagens mecânicas indicava alta permeabilidade do terreno de fundação da barragem. Todavia, ao se observar amostras extraídas dessas sondagens, não foi constatada a existência de camadas ou de lentes de areia que justificassem os altos valores de permeabilidade, pois o solo era constituído essencialmente por argila e silte. Entretanto, no levantamento das paredes da escavação, para construir a ensecadeira, verificou-se a ocorrência de uma cavidade tubular que jorrava grande volume de água. Tal descoberta coincidiu com a identificação de canalículos nos terrenos da fundação da Barragem de Tucuruí, levantando-se, então, a hipótese da existência desses canalículos também na fundação de Balbina. Posteriormente, mapeamentos de detalhe realizados no local mostraram ocorrência de canalículos com diâmetro de até $30 \mathrm{~mm}$ que, sob teste de permeabilidade, mostraram alta capacidade de absorção d'água.

Ocorrências de cavidades tubulares em solos lateríticos na região amazônica já haviam sido relatadas por BUOSI \& CADMAN (1984) e, posteriormente, outros vieram a apresentar seus estudos, como RÉMY et al. (1985) e MELLO et al. (1987 e 1988). A respeito dos canalículos da região amazônica, JURY \& PARAGUASSU (1990) realizaram estudos e os diferenciaram de acordo com sua origem em dois tipos: um gerado por processos físico-químicos e o outro por processos biológicos. Os autores afirmaram que os primeiros possuem extensão mais acentuada e, predominantemente, exibem inclinação vertical com pequenos componentes horizontais, enquanto que os de origem biológica apresentam componentes verticais e horizontais na mesma ordem de grandeza. Verificaram ainda que, no caso particular do minhocuçu, os canalículos possuem inclinação subvertical. 
CADMAN \& BUOSI (1985), ao estudarem os solos da região amazônica, concluíram que os canalículos biológicos foram formados por colônias de termitas, e que eles foram construídos nos períodos de clima seco do Quaternário. Recomenda-se a leitura da publicação de SATHLER \& MESQUITA (1984), que apresentaram sugestão simplificada de classificação dos canalículos, bem como um método de investigação de campo, fundamentados nos trabalhos executados na região da Barragem de Balbina. Assim, para identificá-los, os autores recomendaram que fossem realizadas escavações de trincheiras exploratórias, especialmente nas camadas situadas sobre os solos lateríticos na Amazônia. Recomendaram, ainda, mapeamento criterioso nas paredes da escavação e nos taludes existentes no terreno natural, bem como a análise detalhada dos testemunhos, associando-a aos resultados de permeabilidade em sondagens, ou com acontecimentos anômalos ocorridos durante as perfurações, como a perda d’água de circulação.

Por fim, o maior problema encontrado na área da fundação da Barragem de Balbina foi a alta percolação do solo, com coeficiente da ordem de até $6 \times 10^{-3} \mathrm{~cm} / \mathrm{s}$ obtido nos ensaios em furos de sondagens, associada às ocorrências de canalículos dispostos com diferentes inclinações.

\subsubsection{Projeto de tratamento da fundação da barragem}

Várias alternativas foram estudadas para o tratamento do maciço de fundação, sendo quatro delas com maior grau de detalhamento. A primeira previa a construção de uma trincheira de vedação (cut off) até a rocha sã, interceptando as camadas de aluvião, solo residual e rocha alterada. Na segunda, a trincheira seria menos profunda, atingindo somente até a base do solo residual e, neste caso, a rocha alterada sofreria tratamento por injeção. A terceira alternativa indicada foi semelhante à segunda, com a substituição da trincheira por uma parede de diafragma. Na quarta alternativa, a trincheira seria mais rasa, atingindo 
apenas a base da camada aluvionar e o tratamento das camadas subjacentes, incluindo-se o maciço rochoso, seria efetuado por meio de injeções.

A partir da avaliação técnico-econômica das alternativas apresentadas, em 1984, optou-se pela solução de trincheira de vedação até a base do alúvio e injeção no solo residual e rocha alterada. Optou-se, também, pela injeção de solo-cimento, empregando-se válvula do tipo manchete.

\subsubsection{Método utilizado para a injeção de solo-cimento}

Após a escolha do tipo de tratamento a ser adotado, passou-se para a etapa de experimentos do método, numa área da margem esquerda do Rio Uatumã. Tais experimentos tiveram como objetivo principal a definição das especificações técnicas iniciais, ou seja, a malha dos furos de injeção, volume de calda por fase de injeção, tipo de calda para a bainha e para a injeção (TABELA 3) e espaçamento entre válvulas-manchete.

Encerrada a etapa de experimentos, iniciaram-se os trabalhos de tratamento do solo residual por meio de injeção, ao longo do eixo do barragem, em três linhas paralelas e separadas entre si de $2 \mathrm{~m}$, denominadas montante, central e jusante, conforme mostra a FIGURA 31 (CRUZ, 1996).

Em cada linha de injeção, os furos foram espaçados de $2 \mathrm{~m}$ e deslocados de $1 \mathrm{~m}$ em relação ao furo vizinho da linha adjacente (FIGURA 31). É oportuno destacar que nos furos da linha de jusante foram realizados os ensaios prévios de percolação d’água para determinar a permeabilidade do terreno natural que, comparada com os resultados dos ensaios posteriores às injeções, permitiram verificar a eficiência do tratamento. 


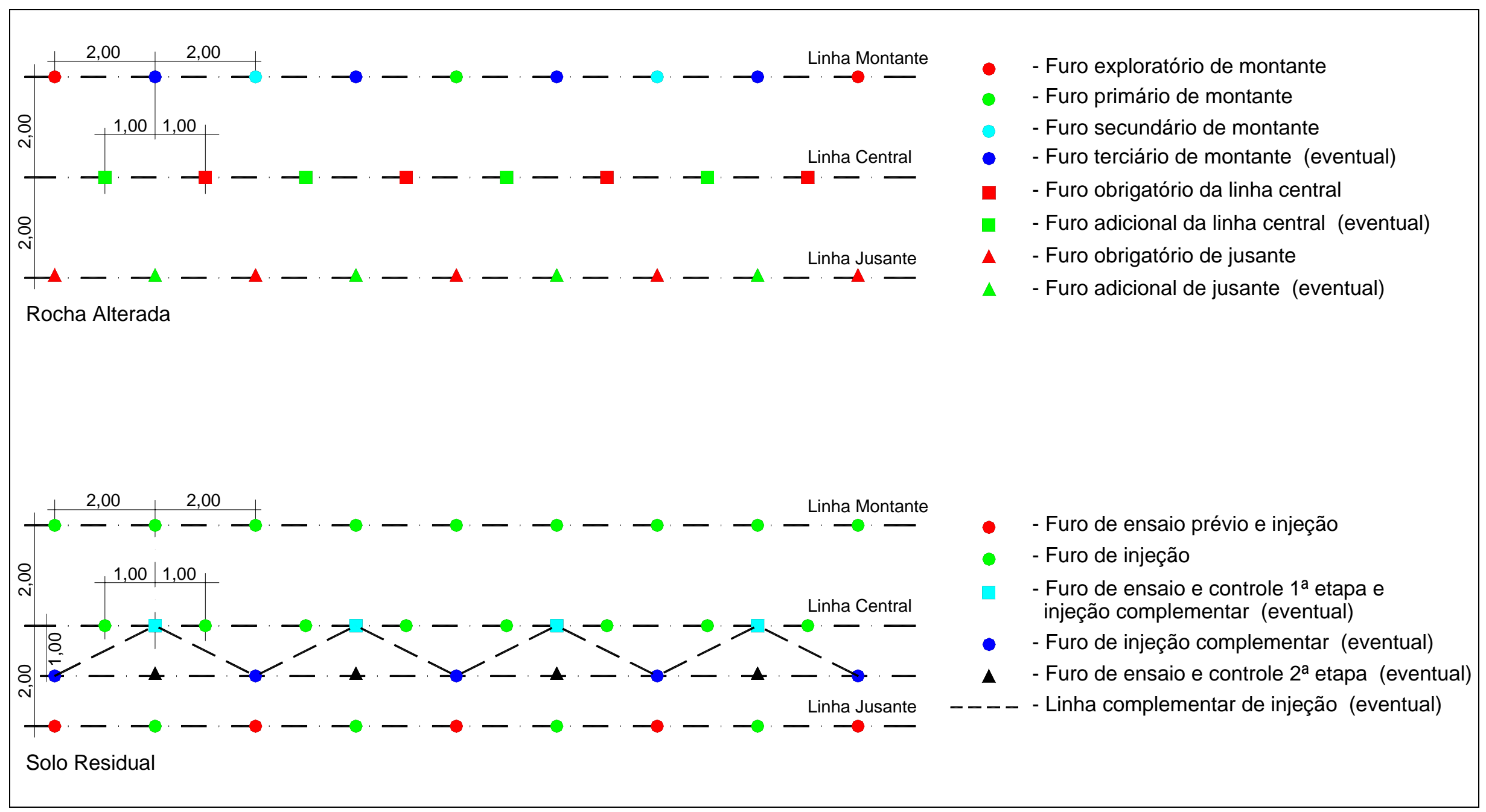

FIGURA 31 - Projeto para tratamento com injeção para impermeabilização do maciço na Barragem de Balbina (MOREIRA et al., 1990). 
As injeções foram iniciadas nos furos localizados na linha de jusante, por meio de campanha de uma série de perfurações e de confecção das bainhas. Injeções simultâneas em dois furos foram permitidas, desde que a distância entre eles superasse 12 m para evitar interferências durante a injeção (MATTOS et al., 1981).

Concluída a campanha de injeção nos furos da linha de jusante, o tratamento passou para a linha de montante, utilizando-se os mesmos critérios da linha anterior. A injeção na cortina de vedação foi encerrada nos furos da linha central que, logo após a perfuração e antes da confecção da bainha, foram submetidos aos ensaios de permeabilidade. Os resultados obtidos nestes ensaios definiam a necessidade ou não em realizar injeções complementares.

A seqüência das atividades em cada furo foi a seguinte:

- perfuração;

- ensaio prévio de permeabilidade, nos furos da linha de jusante;

- instalação do tubo com as válvulas-manchete;

- confecção da bainha com calda de solo-cimento;

- injeção da calda de solo-cimento;

- ensaios de controle da permeabilidade em furos específicos da linha central;

- injeções complementares, em caso de necessidade.

\subsubsection{Perfuração e instalação dos tubos com válvula-manchete}

Os furos, com diâmetro de 5”, destinados à instalação de tubos com válvulasmanchete, foram efetuados com equipamentos rotopercussivos, cuja profundidade variava de acordo com a posição do topo da rocha alterada, pois, nos critérios estabelecidos, foi exigida penetração de pelo menos 0,5 m no maciço alterado (ELETRONORTE, 1985). 
TABELA 3 - Características médias das caldas utilizadas nos experimentos na fundação da Barragem de Balbina (BARRADAS, 1985).

\begin{tabular}{c|c|c|c|c|c|c|c}
\hline Traço & S/A & $\mathbf{c / s}+\mathbf{A}$ & $\mathbf{c} / \mathbf{m}^{3}$ & $\begin{array}{c}\text { Rc } \\
\left(\mathbf{k g f} / \mathbf{c m}^{3}\right)\end{array}$ & $\begin{array}{c}\text { Massa } \\
\text { Específica } \\
\left(\mathbf{g} / \mathbf{c m}^{3}\right)\end{array}$ & $\begin{array}{c}\text { Escoamento } \\
\mathbf{( s )}\end{array}$ & Utilização \\
\hline 1 & 0,32 & 0,36 & 375 & 11,00 & 1,40 & 43,7 & Bainha \\
\hline 2 & 0,36 & 0,26 & 284 & 6,82 & 1,38 & 51,8 & $\begin{array}{c}\text { Bainha e calda de } \\
\text { injeção }\end{array}$ \\
\hline 3 & 0,32 & 0,22 & 240 & 5,64 & 1,34 & 47,7 & $\begin{array}{c}\text { Bainha e calda de } \\
\text { injeção }\end{array}$ \\
\hline 5 & 0,30 & 0,20 & 218 & 4,40 & 1,31 & 48,2 & $\begin{array}{c}\text { Bainha e calda de } \\
\text { injeção }\end{array}$ \\
\hline 6 & 0,50 & 0,14 & 168 & 2,93 & 1,35 & 77,0 & Calda de injeção \\
\hline 7 & 0,45 & 0,12 & 140 & 1,93 & 1,32 & 13,4 & Bainha \\
\hline 8 & 0,45 & 0,07 & 85 & 0,73 & 1,29 & 44,6 & Calda de injeção \\
\hline
\end{tabular}

S/A: relação de solo/água.

c/s + A: relação cimento/solo + água.

$\mathrm{c} / \mathrm{m}^{3}$ : cimento por metro cúbico de calda.

Rc: resistência à compressão simples de corpos com 28 dias de idade.

Escoamento: no funil de Marsh, com 4,75 mm, exceto o traço 7, que foi realizado no cone com 10 mm de diâmetro.

As válvulas-manchete foram instaladas nos tubos de PVC com 3” de diâmetro, sendo que a primeira delas foi posicionada a $0,5 \mathrm{~m}$ da extremidade inferior do tubo, e as demais, distanciada de 0,5 m uma da outra, mantendo-se o espaçamento de constante até cerca de 5 m abaixo da cota de escavação da fundação.

Convém lembrar que à medida que se concluía a perfuração, introduzia-se o tubo de PVC com as válvulas-manchete. Em seguida, o espaço anelar entre o tubo e a parede do furo era preenchido, imediatamente, com calda de solo-cimento para confecção da bainha, evitando o desmoronamento das paredes das perfurações. 


\subsubsection{Execução da bainha e injeção}

A fixação do tubo de PVC no furo foi realizada por meio de calda de solocimento (bainha), injetada a partir da primeira manchete, situada junto à extremidade inferior do tubo de PVC. Para confeccionar a bainha, foi utilizado um determinado traço de calda de maneira que a resistência, após a cura de 28 dias, apresentasse valor da ordem de 3 kgf/cm², com tolerância de \pm 1 kgf/ cm² (ELETRONORTE, 1984a).

O processo de injeção, no sentido ascendente, foi iniciado após a pega da calda da bainha, rompendo-se as válvulas-manchete através da aplicação de pressões crescentes. Nesta etapa do trabalho, foi empregada calda de injeção, cuja resistência aos 28 dias apresentasse valores médios de 1,5 kgf/ $\mathrm{cm}^{2}$, com 95\% de ocorrência entre 0,75 e 2,25 $\mathrm{kgf} / \mathrm{cm}^{2}$ (ELETRONORTE, op. cit.).

O critério para paralisação da injeção foi estabelecido de acordo com o volume máximo de consumo da calda para evitar que a injeção atingisse grandes distâncias dos furos. Limitou-se o volume em $300 \ell$ por manchete, estabelecido a partir dos resultados dos experimentos realizados num campo de prova e de cálculos teóricos.

Um outro critério utilizado para paralisar a injeção foi a absorção nula de calda, durante um período de 10 minutos, quando a válvula era submetida à pressão de injeção.

Ressalta-se que, de acordo com os profissionais que executaram as injeções, todas as informações técnicas relativas aos valores das pressões de iniciação da ruptura do maciço e da injeção, bem como dos volumes absorvidos por manchete, além das ocorrências durante o processo de injeção, foram registrados em boletins técnicos individuais de cada furo. 


\subsubsection{Ensaios de controle}

Após a conclusão da campanha de injeção nas linhas de jusante e montante, foram realizados ensaios de permeabilidade em furos de sondagens da linha central, com procedimentos semelhantes aos adotados durante a fase de investigação.

Nos trechos do maciço, onde o coeficiente de permeabilidade medido nos ensaios situasse abaixo de $10^{-4} \mathrm{~cm} / \mathrm{s}$, o projeto determinava que o furo fosse apenas obturado. Para valores de permeabilidade entre $10^{-4}$ e $10^{-3} \mathrm{~cm} / \mathrm{s}$, foi necessário injetar $300 \ell$ de calda por manchete. Para os trechos do maciço que apresentavam coeficiente de permeabilidade superior a $10^{-3} \mathrm{~cm} / \mathrm{s}$, foi necessário injetar $500 \ell$ de calda por manchete. Nestes locais, após o tratamento complementar, executou-se nova campanha de sondagem para avaliação da permeabilidade do terreno. Para análise dos resultados dos novos ensaios de permeabilidade, foram utilizados os mesmos critérios anteriores. Não há registro de casos em que houve a necessidade de uma terceira campanha de ensaio de avaliação da permeabilidade do maciço.

\subsection{Tratamento das Fundações da Cooperativa}

A maioria das edificações da unidade industrial da Cooperativa Central de Laticínios do Estado de São Paulo é bastante antiga, e nos últimos anos algumas delas têm sofrido recalques e afundamentos, tendo como conseqüência o aparecimento de trincas nas paredes e estruturas. Nesta região, localizam-se o laboratório, a casa de caldeiras e a caixa d’água (FIGURA 32).

Em 1996, foi elaborado um laudo técnico para avaliar os problemas de recalques no terreno. Para isso, foi necessário realizar uma campanha de investigação com sondagens que revelaram as precárias condições das fundações dos edifícios. Após análise da situação, a empresa proprietária optou pelo tratamento com injeção de calda de solo-cimento, 
empregando-se o método do fraturamento hidráulico, conhecido também como “clacagem”. O tratamento foi realizado em 1997 e teve como objetivo principal o preenchimento dos vazios detectados no solo de fundação dos edifícios do laboratório, da caixa d’água e da casa das caldeiras.

\subsubsection{Aspectos geológico-geotécnicos e problemas encontrados}

As estruturas da Cooperativa foram assentadas em solo superficial sustentado pelos sedimentos terciários da Bacia de Taubaté (RICCOMINI, 1989). A campanha de sondagens mecânicas revelou a existência de uma camada superficial de solo sobreposta a outras duas camadas constituídas por sedimentos terciários (FIGURA 33).

Os ensaios padronizados SPT realizados na camada superficial de solo, constituída por argila silto-arenosa avermelhada e com espessura inferior a 6 m de espessura (FIGURA 33), mostraram índices de resistência à penetração relativamente baixos, variando de 2 a 5 golpes. Localmente, a camada apresentou consistência muito mole, verificada pelo avanço brusco da ferramenta de perfuração.

Sob essa camada de solo ocorre uma camada sedimentar constituída por areia com cascalho, com espessura da ordem de $9 \mathrm{~m}$, fofa a medianamente compacta, com índices de resistência à penetração de 2 a 26 golpes, de cores amarelada, roxa e cinza. O nível d'água localiza-se na base desta camada de areia.

A segunda camada sedimentar da Bacia de Taubaté, com espessura não determinada e situada abaixo dos sedimentos descritos anteriormente, é composta por argila siltosa pouco arenosa, cinza, rija, com índice de penetração da ordem de 35 golpes.

As investigações realizadas na época mostraram que a camada superficial do solo, onde estão posicionadas as fundações das edificações, sofreu desestruturação por ataque de águas agressivas, devido à sua característica argilosa e pelo fato de receber a 
primeira descarga das águas provenientes de vazamentos do processo industrial (PROGECONSULT, 1997).

Análises posteriores mostraram, ainda, que nos trechos da camada superficial de solo argiloso, com valores baixos de resistência à penetração (ensaio SPT), havia concentração de solo desestruturado. Verificaram, também, que à medida que a desestruturação ia avançando por gravidade, formavam-se pequenas bacias na superfície do solo, que funcionavam como verdadeiros reservatórios de águas agressivas. Cavidades com volume da ordem de $0,25 \mathrm{~m}^{3}$ foram encontradas nas regiões mais profundas da camada de solo.

Por outro lado, os estudos revelaram que a camada sedimentar terciária, constituída essencialmente por areia e cascalho, não sofreu desestruturação, devido à sua composição mineralógica (quartzo) resistente às águas ácidas, além de ser bastante permeável, permitindo, portanto, a drenagem das águas agressivas.

\subsubsection{Tratamento efetuado}

O tratamento proposto visou o preenchimento das cavidades existentes na camada de argila silto-arenosa, com a finalidade de aumentar a capacidade de suporte para a fundação. Para atingir esse objetivo, foi idealizado um projeto que promovesse o fraturamento hidráulico (clacagem) do maciço para garantir a obstrução através da introdução da calda de solo-cimento.

A região que sofreu tratamento com injeção de solo-cimento foi de aproximadamente $1.400 \mathrm{~m}^{2}$, dividida em três áreas que abrangem as edificações do laboratório, da caixa d‘água e da casa das caldeiras, conforme mostra a FIGURA 32. 


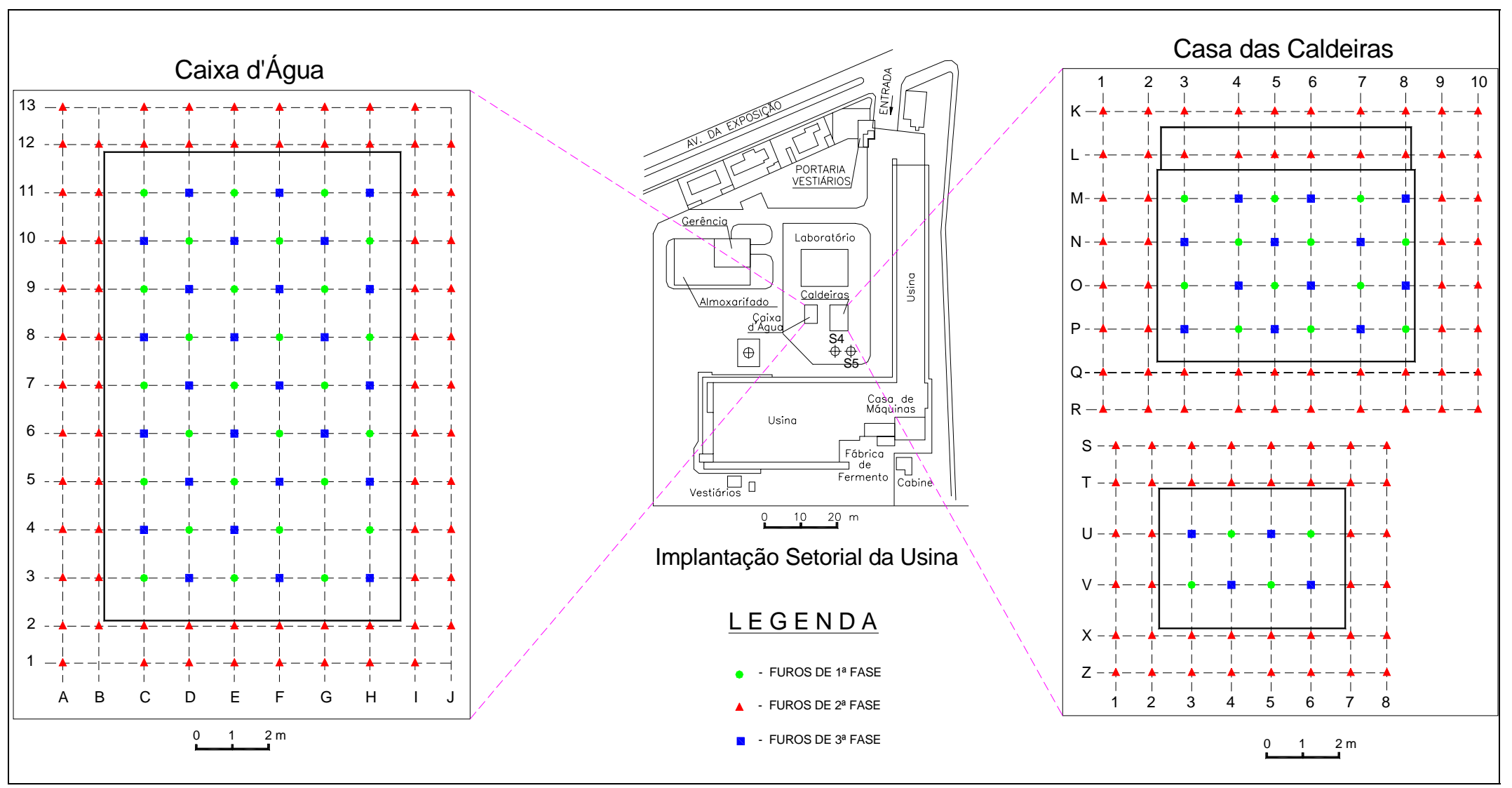

FIGURA 32 - Localização das edificações na unidade industrial da Cooperativa Central de Laticínios (PROGECONSULT, 1997). 
A técnica empregada no tratamento foi a mesma daquela empregada nos trabalhos realizados na Barragem de Balbina. Basicamente, o tratamento foi constituído pela promoção de fraturamento hidráulico no maciço e preenchimento com calda de solo-cimento por meio de tubos de PVC contendo válvulas-manchete.

Esses tubos foram instalados em furos, distribuídos em malha de 1 x $1 \mathrm{~m}$ (FIGURA 32), com profundidade de 6 m. Foram executados 196 furos com diâmetro de 3”, utilizando-se perfuratriz elétrica, rotativa com baixa rotação e tendo como ferramenta de perfuração uma coroa destrutiva do tipo trépano.

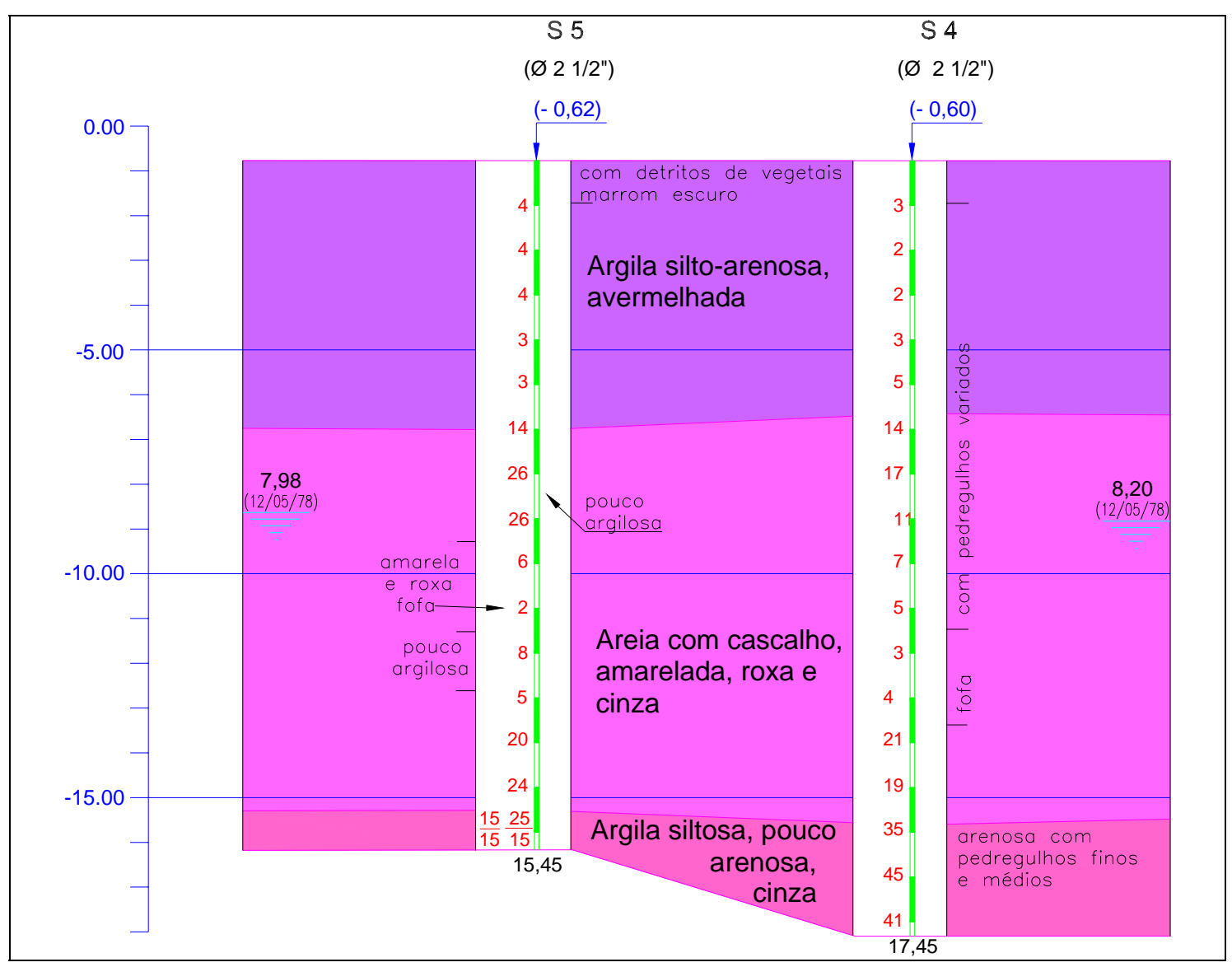

FIGURA 33 - Seção típica na área do tratamento (PROGECONSULT, 1997).

Após a conclusão de cada furo e a colocação do tubo de PVC (diâmetro de 3/4”), devidamente preparado com as válvulas-manchete, foi efetuada a injeção da bainha, a cada 0,5 m, a partir da primeira válvula instalada na parte inferior do tubo. Após a cura da bainha, 
a calda de solo-cimento foi introduzida a uma velocidade de $40 \ell /$ min até atingir o volume de $200 \ell$ por válvula-manchete.

Devido à ocorrência de cavidades no terreno, o consumo de calda para execução da bainha foi elevado. Para confecção das bainhas de todos os furos, foram necessários aproximadamente $160 \mathrm{~kg}$ de cimento, $340 \mathrm{~kg}$ de solo e $820 \ell$ de água. Estas quantidades revelam que para a confecção das bainhas o traço da calda obedeceu à seguinte proporção, em massa: $\mathrm{C}: \mathrm{Ag}: \mathrm{A}=1: 2: 5$, respectivamente, cimento, solo e água.

O solo empregado na composição das caldas não foi analisado granulometricamente em laboratório, tendo sido descrito através da análise táctil-visual. Trata-se de uma argila pouco siltosa, utilizada na fabricação de tijolos cerâmicos da região.

Para facilitar as operações de campo, os traços especificados em projeto foram transformados em medidas de volume. Para isso, foi necessário determinar a massa específica aparentes do cimento, do solo e a umidade natural do solo, cujos valores médios obtidos foram, respectivamente, $0,94 \mathrm{~g} / \mathrm{cm}^{3}, 0,92 \mathrm{~g} / \mathrm{cm}^{3}$ e $15 \%$.

As caldas de injeção também foram confeccionadas com os mesmos materiais, com a seguinte proporção: C:Ag:A = 1:3,4:8,4, respectivamente, cimento, solo e água.

Ainda de acordo com o relatório PROGECONSULT (1997), os traços definidos mostraram-se perfeitamente adequados dentro das especificações estabelecidas quanto à densidade $(1,28 \mathrm{~kg} / \ell$ e $1,32 \mathrm{~kg} / \ell$, respectivamente, para a calda de injeção e bainha); à fluidez (entre 9 e 14 segundos, no funil de Marsh com diâmetro de $10 \mathrm{~mm}$ ) e ao fator de sedimentação $(\leq 5 \%)$.

As TABELAS 4 e 5 mostram o consumo de caldas, por furo, para confecção das bainhas e injeções no maciço, para diferentes locais do tratamento. A identificação dos furos foi feita de acordo com as coordenadas estabelecidas no projeto (FIGURA32).

TABELA 4 - Volume de calda utilizada no tratamento da fundação do laboratório. 


\begin{tabular}{|c|c|c|c|c|c|c|c|c|}
\hline \multirow{2}{*}{ Furo } & \multicolumn{2}{|c|}{ Volume (I) } & \multirow{2}{*}{ Furo } & \multicolumn{2}{|c|}{ Volume (I) } & \multirow{2}{*}{ Furo } & \multicolumn{2}{|c|}{ Volume (I) } \\
\hline & Bainha & Injeção & & Bainha & Injeção & & Bainha & Injeção \\
\hline B1 & 106 & 940 & E1 & 66 & 7.380 & H1 & 56 & 788 \\
\hline B2 & 146 & 2.555 & E2 & 36 & 2.166 & H2 & 32 & 5.539 \\
\hline B3 & 50 & 1.615 & E3 & 200 & 382 & H3 & 30 & 1.910 \\
\hline B4 & 31 & 3.045 & E4 & 40 & 3.010 & H4 & 20 & 708 \\
\hline B5 & 24 & 558 & E5 & 1055 & 960 & H5 & 28 & 5.155 \\
\hline B6 & 64 & 1.185 & E5 & 75 & 3.210 & H6 & 85 & 959 \\
\hline B7 & 60 & 674 & E7 & 35 & 1.750 & H7 & 20 & 1.685 \\
\hline B8 & 25 & 2.000 & E8 & 16 & 2.630 & H8 & 42 & 1.510 \\
\hline B9 & 25 & 1.967 & E9 & 26 & 1.325 & H9 & 30 & 3.430 \\
\hline B10 & 25 & 505 & E10 & 46 & 3.300 & H10 & 20 & 760 \\
\hline B11 & 150 & 1.803 & E11 & 20 & 3.300 & H11 & 30 & 2.430 \\
\hline B12 & 309 & 1.600 & E12 & 35 & 1.700 & H12 & 25 & 3.870 \\
\hline B13 & 960 & 3.920 & E13 & 40 & 525 & H13 & 40 & 778 \\
\hline C1 & 41 & 3.458 & F1 & 42 & 4.130 & I1 & 46 & 3.282 \\
\hline C2 & 31 & 3.330 & F2 & 31 & 2.044 & I2 & 34 & 1.362 \\
\hline C3 & 30 & 1.228 & F3 & 46 & 1.240 & I3 & 18 & 3.580 \\
\hline $\mathrm{C} 4$ & 35 & 1.555 & F4 & 610 & 259 & I4 & 100 & 3.474 \\
\hline C5 & 65 & 580 & F5 & 70 & 585 & I5 & 73 & 2.870 \\
\hline C6 & 30 & 3.500 & F6 & \multicolumn{2}{|c|}{ Eliminado } & I6 & - & 5.825 \\
\hline C7 & 35 & 1.585 & F7 & 45 & 3.425 & I7 & 1312 & 4.950 \\
\hline C8 & 24 & 3.200 & F8 & 30 & 3.310 & I8 & \multicolumn{2}{|c|}{ Eliminado } \\
\hline C9 & 56 & 3.500 & F9 & 20 & 977 & I9 & 26 & 1.684 \\
\hline C10 & 64 & 2.600 & F10 & 28 & 2.870 & I10 & 26 & 2.330 \\
\hline C11 & 600 & 2.840 & F11 & 20 & 1.810 & I11 & 128 & 3.075 \\
\hline C12 & 25 & 2.300 & F12 & 25 & 2.420 & I12 & 25 & 1.582 \\
\hline C13 & 30 & 5.530 & F13 & 60 & 334 & I13 & 25 & 731 \\
\hline D1 & 31 & 3.078 & G1 & 42 & 5.170 & $\mathrm{~J} 1$ & 66 & 9.730 \\
\hline D2 & 34 & 940 & G2 & 36 & 4.010 & $\mathrm{~J} 2$ & 118 & 4.350 \\
\hline D3 & 35 & 2.354 & G3 & 165 & 415 & J3 & 68 & 2.370 \\
\hline D4 & 70 & 2.630 & G4 & 36 & 3.905 & $\mathrm{~J} 4$ & 145 & 5.520 \\
\hline D5 & 35 & 655 & G5 & 195 & 485 & J5 & 130 & 1.910 \\
\hline D6 & 30 & 2.600 & G6 & 30 & 6.515 & J6 & 462 & 1.630 \\
\hline D7 & 15 & 3.125 & G7 & 35 & 590 & $\mathrm{~J} 7$ & 64 & 1.440 \\
\hline D8 & 45 & 2.515 & G8 & 20 & 2.785 & J8 & 80 & 3.285 \\
\hline D9 & 30 & 3.590 & G9 & 48 & 1.632 & J9 & 630 & 1.788 \\
\hline D10 & 56 & 2.840 & G10 & 20 & 3.300 & $\mathrm{~J} 10$ & 80 & 4.200 \\
\hline D11 & 237 & 2.600 & G11 & 110 & 2.495 & J11 & 40 & 2.620 \\
\hline D12 & 30 & 1.274 & G12 & 35 & 1.684 & $\mathrm{~J} 12$ & 90 & 2.228 \\
\hline D13 & 880 & 880 & G13 & 60 & 1.454 & J13 & 68 & 2.230 \\
\hline
\end{tabular}

$\mathrm{N}^{0}$ de furos injetados $=115$

Volume total injetado(l) $=279.038$

Volume total na bainha $(\mathrm{l})=\mathbf{1 2 . 4 3 0}$

Volume médio por furo injetado no solo $(\mathrm{l} /$ furo $)=\mathbf{2 . 4 2 6 , 4 1}$ 
TABELA 5 - Volume de calda utilizado no tratamento das fundações da caixa d’água e da casa das caldeiras.

\begin{tabular}{|c|c|c|c|c|c|c|c|c|}
\hline \multicolumn{3}{|c|}{ Caixa d'água } & \multicolumn{6}{|c|}{ Casa das caldeiras } \\
\hline \multirow[t]{2}{*}{ Furo } & \multicolumn{2}{|c|}{ Volume (l) } & \multirow[t]{2}{*}{ Furo } & \multicolumn{2}{|c|}{ Volume (l) } & \multirow[t]{2}{*}{ Furo } & \multicolumn{2}{|c|}{ Volume (l) } \\
\hline & Bainha & Injeção & & Bainha & Injeção & & Bainha & Injeção \\
\hline S2 & 40 & 3140 & L1 & 150 & 4920 & P1 & 26 & 6320 \\
\hline S3 & 25 & 2740 & L2 & 300 & 13980 & P2 & 64 & 2270 \\
\hline S4 & 135 & 3965 & L3 & 300 & 7195 & P3 & 20 & 5200 \\
\hline S5 & 65 & 2780 & L4 & 400 & 4965 & P4 & 600 & 4875 \\
\hline S6 & 20 & 3400 & L5 & 25 & 5825 & P5 & 40 & 1240 \\
\hline \multirow[t]{2}{*}{ S7 } & \multirow[t]{2}{*}{20} & \multirow[t]{2}{*}{4000} & L6 & 25 & 5335 & P6 & 60 & 3590 \\
\hline & & & L7 & 150 & 8702 & P7 & 25 & 6380 \\
\hline $\mathrm{T} 1$ & 860 & 2170 & L8 & 180 & 2520 & P9 & 20 & 7175 \\
\hline T2 & 240 & 2365 & L9 & 120 & 8140 & & & \\
\hline T3 & 165 & 2290 & & & & Q1 & 50 & 2310 \\
\hline T4 & 25 & 3210 & M1 & 150 & 4620 & Q2 & 24 & 2070 \\
\hline T5 & 100 & 3085 & M2 & 950 & 8630 & Q3 & 50 & 2900 \\
\hline T6 & 70 & 3105 & M3 & 30 & 6445 & Q4 & 660 & 4710 \\
\hline \multirow[t]{2}{*}{$\mathrm{T} 7$} & \multirow[t]{2}{*}{105} & \multirow[t]{2}{*}{4125} & M4 & 30 & 4870 & Q5 & 55 & 2500 \\
\hline & & & M5 & 160 & 7000 & Q6 & 40 & 5600 \\
\hline U1 & 40 & 2550 & M6 & 105 & 1820 & Q7 & 170 & 2570 \\
\hline U2 & 200 & 610 & M7 & 20 & 4985 & Q8 & 70 & 3920 \\
\hline U3 & 30 & 2320 & M9 & 35 & 4510 & Q9 & 100 & 3160 \\
\hline U4 & 45 & 10640 & & & & & & \\
\hline U5 & 70 & 6490 & N1 & 1400 & 6960 & & & \\
\hline U6 & 70 & 1690 & N4 & 25 & 5590 & & & \\
\hline \multirow[t]{2}{*}{ U7 } & \multirow[t]{2}{*}{25} & \multirow[t]{2}{*}{2480} & N5 & 60 & 4100 & & & \\
\hline & & & N6 & 435 & 4420 & & & \\
\hline V1 & 158 & 2590 & N7 & 20 & 5185 & & & \\
\hline V2 & 20 & 1850 & N9 & 35 & 4570 & & & \\
\hline V3 & 20 & 4090 & & & & & & \\
\hline V4 & 35 & 6459 & O1 & 2000 & 13625 & & & \\
\hline V5 & 70 & 3680 & O3 & 30 & 7100 & & & \\
\hline V6 & 60 & 3925 & $\mathrm{O} 4$ & 30 & 4470 & & & \\
\hline \multirow[t]{2}{*}{ V7 } & \multirow[t]{2}{*}{35} & \multirow[t]{2}{*}{2230} & O5 & 60 & 6800 & & & \\
\hline & & & O6 & 690 & 4920 & & & \\
\hline X1 & 40 & 1750 & O7 & 40 & 2510 & & & \\
\hline X2 & 20 & 2855 & O9 & 35 & 3965 & & & \\
\hline X3 & 15 & 2445 & & & & & & \\
\hline $\mathrm{X} 4$ & 95 & 3170 & & & & & & \\
\hline X5 & 25 & 2620 & & & & & & \\
\hline X6 & 25 & 3075 & & & & & & \\
\hline $\mathrm{X} 7$ & 75 & 2970 & & & & & & \\
\hline & & & \multirow{2}{*}{\multicolumn{2}{|c|}{$\begin{array}{l}\text { Caixa d'água } \\
34\end{array}$}} & Casa de & caldeir & & \\
\hline \multirow{3}{*}{\multicolumn{3}{|c|}{$\begin{array}{l}\text { Número de furos } \\
\text { Volume da bainha } \\
\text { Vol. total injetado }\end{array}$}} & & & 47 & & & \\
\hline & & & 3.043 & & $10.064 \ell$ & & & \\
\hline & & & 110.86 & & 245.467 & & & \\
\hline
\end{tabular}




\section{BARRAGEM DE RASGÃO}

A Usina Hidrelétrica de Rasgão, localizada no Rio Tietê, pertence à Empresa Metropolitana de Águas e Energia S.A. - EMAE, denominada ELETROPAULO Eletricidade de São Paulo S.A., na época do tratamento efetuado. Esta usina foi construída entre os anos de 1924 e 1925 pela São Paulo Tramway Light and Power Company para diminuir os efeitos da seca, relativos à falta de energia elétrica, na capital paulista. Ela é composta por uma barragem principal, um canal de adução, dois condutos forçados e uma casa de força que contém duas unidades de geração. A barragem principal, fundada sobre maciço rochoso alterado, foi construída em concreto do tipo arco-gravidade, com $22 \mathrm{~m}$ de altura e 130 m de comprimento. Foi edificada, também, uma tomada d’água junto ao reservatório, com objetivo de permitir a execução de serviços de manutenção nos taludes laterais do canal de adução. O canal possui pouco mais de $200 \mathrm{~m}$ de comprimento e foi escavado em rocha sã e em solo residual, respectivamente, na parte a montante e a jusante do traçado do canal. Na região a jusante e no final do canal de adução, encontra-se o conjunto de geração, composto por uma tomada d’água da usina para controle das vazões, dois condutos forçados e uma casa de força. Na casa de força, estão abrigadas duas unidades geradoras com capacidade nominal de 7,2 MW cada. Todo conjunto gerador está assentado em solo residual, diferenciando-se da maioria das usinas brasileiras construídas nos últimos anos, que estão fundadas em maciço rochoso (PASTORE, 1998). A FIGURA 34 mostra a disposição das estruturas da usina.

Para permitir a reversão das águas do Rio Tietê e de seu principal afluente, o Rio Pinheiros, com a finalidade de garantir a geração de energia elétrica na Usina de Cubatão, foi construída, em 1956, a Barragem de Pirapora, situada no remanso do reservatório de Rasgão. Nestas condições, a descarga de água para Rasgão foi reduzida e a usina, desativada em 1966, passou a operar como compensador síncrono. 


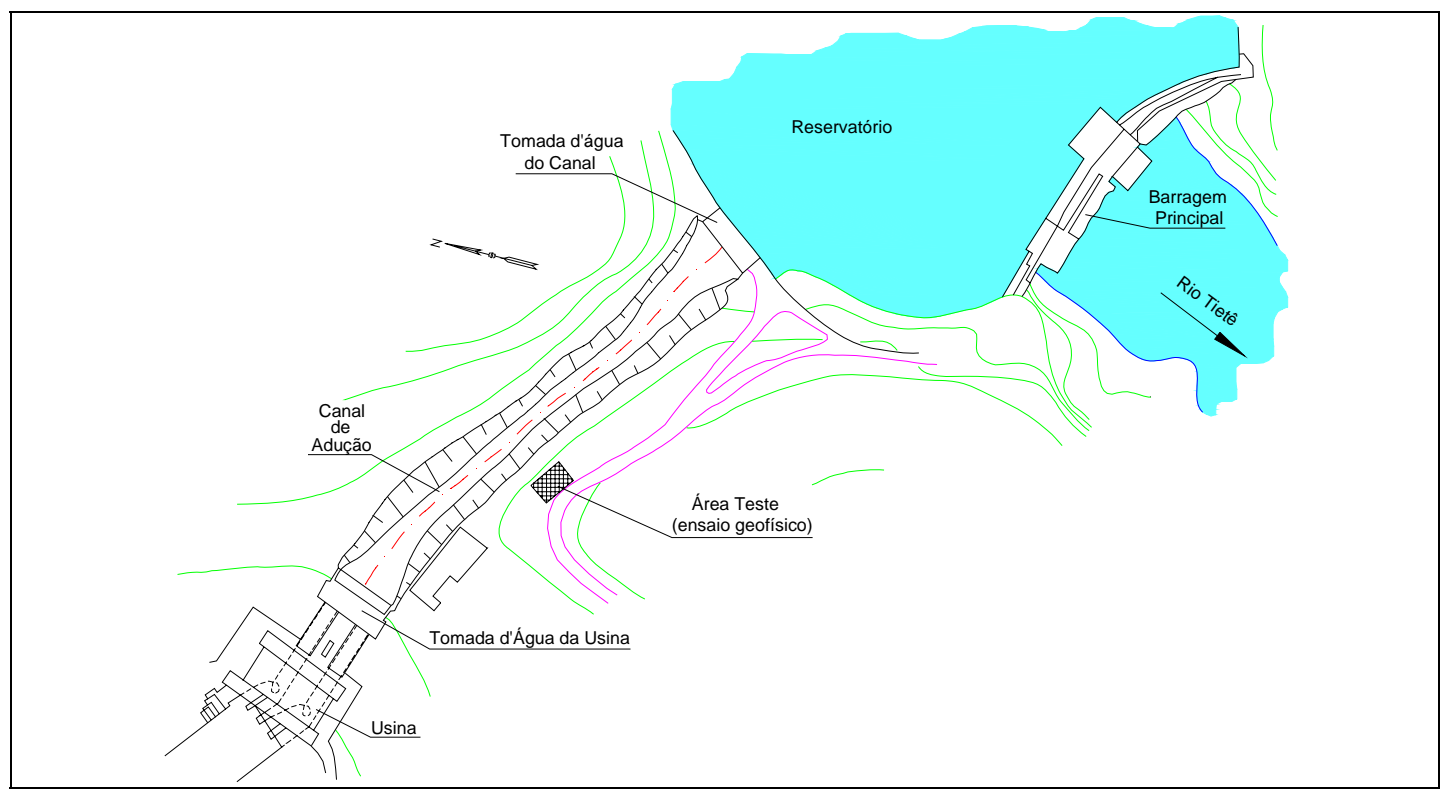

FIGURA 34 - Planta geral da área da Usina de Rasgão.

Em meados da década de 80, no momento em que se vislumbrava a possibilidade de racionamento de energia elétrica a partir de 1993, devido à redução nos investimentos em todo o setor elétrico nacional, técnicos da empresa concessionária (antiga ELETROPAULO) decidiram reativar a Usina de Rasgão. Para isso, foi necessário realizar uma campanha de investigações, tanto nos maciços das fundações como nas estruturas de concreto. Estas investigações foram realizadas, em 1985, com a finalidade de elaborar um projeto que contemplasse a recuperação de todas as estruturas de concreto, a recomposição de parte dos taludes do canal de adução, a melhoria das condições de estabilidade da barragem principal, a consolidação do maciço terroso que sustenta a estrutura da usina e a redução da percolação de água pela fundação da tomada d'água da usina.

Em meados de 1986, foram iniciados os trabalhos de recuperação da usina e encerrados dois anos depois, com a reinauguração de um dos conjuntos geradores, já que o outro necessitava, ainda, de reformas no circuito elétrico.

\subsection{Síntese dos aspectos geológicos}


A Usina Hidrelétrica de Rasgão está instalada no Planalto Atlântico, na Serrania de São Roque, onde o relevo é acidentado com ocorrência de serras sustentadas por corpos de rocha quartzítica. As maiores altitudes das montanhas são encontradas na serra do Boturuna, com valores de 1.200 m, enquanto que os vales situam-se, em geral, a altitudes de $700 \mathrm{~m}$.

A drenagem é de alta densidade com padrão dendrítico a retangular, refletindo as características das rochas ali presentes, respectivamente, granítica e metamórfica.

Ocorrem na região metamorfitos do Grupo São Roque, com predominância dos filitos, seguidos por metarenitos bandados, metarenitos arcoseanos e quartzitos. Rochas calcárias e dolomíticas encontram-se lenticularizadas e intercaladas nos filitos e nos metarcóseos. Anfibolitos metabasíticos de origem vulcânica também estão distribuídos na área.

Na área da Usina de Rasgão, estão presentes rochas granitóides, pertencentes ao batólito de São Roque (HASUI et al., 1978), apresentando textura granular hipidiomórfica porfirítica, dada pela presença de megacristais de feldspato potássico (SANTORO, 1984). Na região da ombreira esquerda da barragem principal, ocorrem filitos de granulação fina, enquanto que na ombreira oposta, a barragem está assente sobre rochas do tipo granitóides. Na região central da barragem, são encontradas rochas cataclásticas, produtos de intenso movimento tectônico que ocorreu ao longo da Falha de Rasgão (FIGURA 35). 


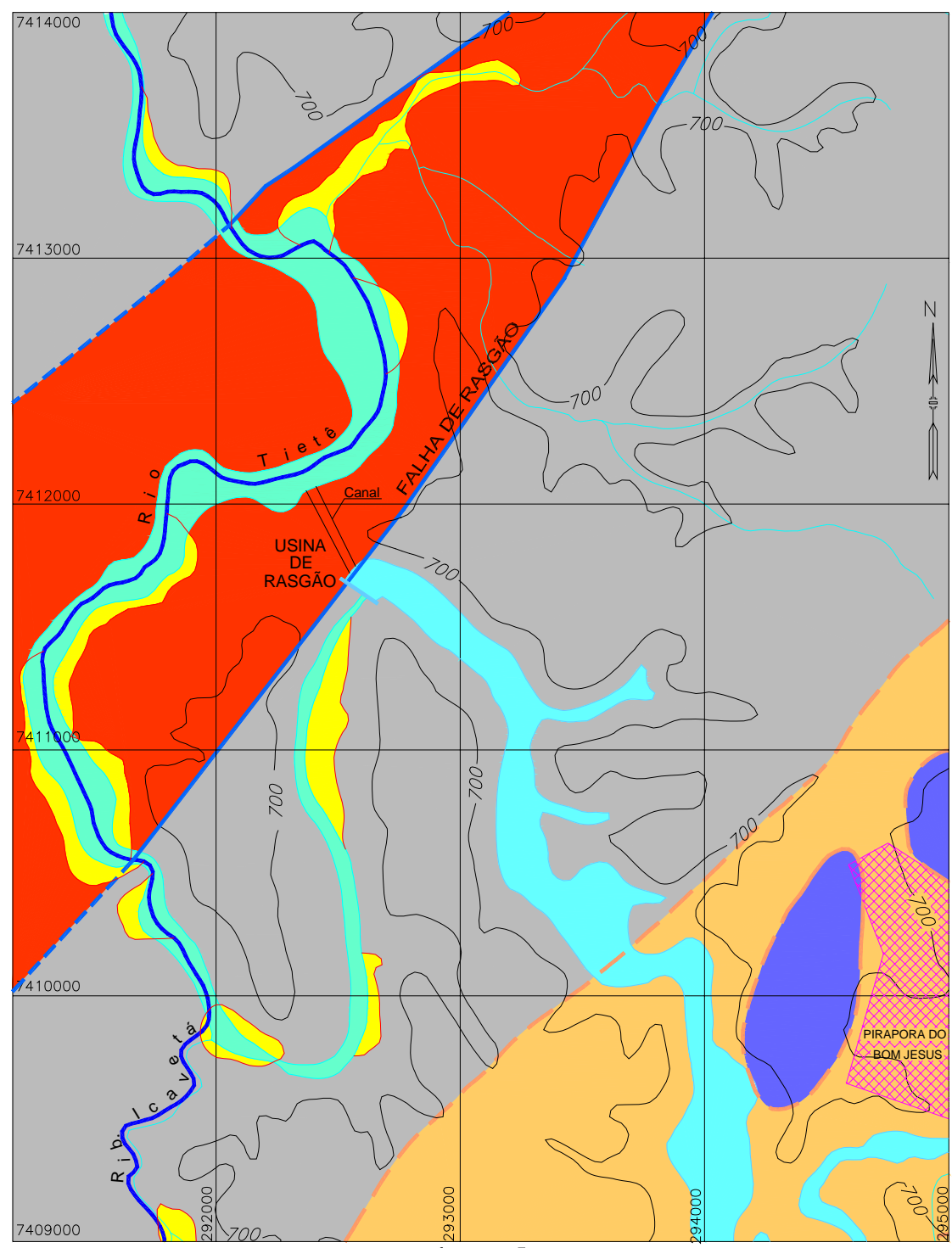

\section{LEGENDA}

Sedimentos aluvionares inconsolidados: argilas, areias e cascalhos

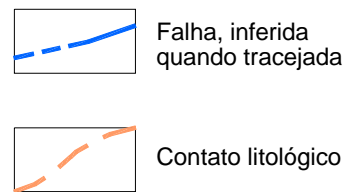

Metarcóseo e metarenitos. Fragmentos grãos de feldspatos e quartzo ocorrem em quantidades variáveis. Com intercalações de filitos e xistos

Filitos de granulação fina, foliado, micáceo e sedoso

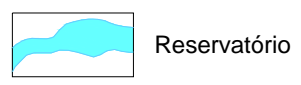

Calcários e dolomitos. Rochas maciças, com pactas, cinza escura

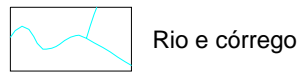

Rochas leucocráticas, batólito de São Roque com zonas cataclasadas e hidrotermalizadas

Escala Gráfica

$$
\begin{array}{llllll}
-250 & 0 & 250 & 500 & 750 & 1.000 \mathrm{~m}
\end{array}
$$

FIGURA 35 - Mapa geológico simplificado da região da Barragem de Rasgão (IPT, 1984b modificado). 
Os testemunhos de sondagens mecânicas executadas na Usina de Rasgão mostraram que sobre o granitóide inalterado (rocha sã), cujo topo em geral ocorre a profundidades maiores que $35 \mathrm{~m}$, ocorre uma camada de rocha alterada de cores amarelada e rósea e com cerca de 15 m de espessura. Ensaios para determinação do coeficiente de permeabilidade realizados nesta camada mostraram valores elevados, da ordem de $10^{-1} \mathrm{~cm} / \mathrm{s}$. Sobreposto a esta camada de rocha alterada, encontra-se o solo de alteração ou residual, com coeficiente de permeabilidade variando de $10^{-3}$ a $10^{-4} \mathrm{~cm} / \mathrm{s}$.

Em toda área de domínio da usina ocorre o solo coluvionar com espessura variável em torno de 2 m, atingindo localmente 5 m (IYOMASA, 1994).

As investigações realizadas permitiram dividir o maciço terroso em duas camadas distintas de solo, de acordo com as suas características geológicas: a superior, com granulação mais fina, não exibe de maneira clara as estruturas reliquiares da rocha, e a inferior, composta essencialmente de areia, conserva nitidamente a foliação e as fraturas geológicas. A camada superior, em processo de decomposição mais acentuado, apresenta-se laterizada e é constituída predominantemente por areia fina silto-argilosa, micácea, enquanto que a inferior, em processo de alteração ainda imaturo, é constituída por areia de granulação média a grossa, micácea, preservando, ainda, fragmentos de minerais (feldspatos) pouco alterados. As FIGURAS 36 e 37 mostram, respectivamente, as seções geológicas na tomada d’água da usina e na casa de força.

\subsection{Problemas encontrados e soluções propostas}

Durante a campanha de investigação, realizada em 1985, foram encontradas altas percolações de água pelos maciços de fundação, vazamentos pelas estruturas de concreto, piping no maciço terroso sob a usina, além da confirmação de instabilidades dos taludes laterais do canal de adução e da barragem principal. 
A Barragem de Rasgão foi construída sobre três litotipos distintos (filitos, cataclasitos e granitóides), mencionados anteriormente, que apresentaram diferentes problemas em função das características geológicas e estruturais das rochas. Vazamentos intensos de água em superfície foram encontrados na região onde ocorrem rochas cataclásticas, que se desenvolveram ao longo da Falha de Rasgão. Esta estrutura está posicionada transversalmente ao eixo da barragem (FIGURA 35), e por esse motivo facilita a fuga de água do reservatório. Na ombreira esquerda, foi observado que a fuga de água pelo filito alterado era bem menor, e na ombreira direita, onde ocorre o granitóide, os ensaios de permeabilidade não revelaram significativa percolação de água.

Outro problema relacionado às características do maciço rochoso de fundação foi a baixa qualidade geomecânica das rochas, em especial dos filitos e cataclasitos. Da ombreira esquerda para o centro da barragem, onde predominam essas rochas, o maciço rochoso apresenta-se alterado e, localmente, muito alterado.

Ao longo de toda extensão da barragem, foi idealizado um projeto de injeção com calda de cimento para reduzir o fluxo de água pelo maciço de fundação. Na parte a montante e no trecho entre a ombreira esquerda e a parte central da barragem, foi projetada também uma laje de concreto para impedir a fuga de água pelo contato concreto/rochas alteradas (filitos e cataclasitos). A escavação do maciço para construção dessa laje em forma da letra L (plinto), foi feita com auxílio de picareta que evidencia a baixa qualidade geomecânica das rochas presentes. 


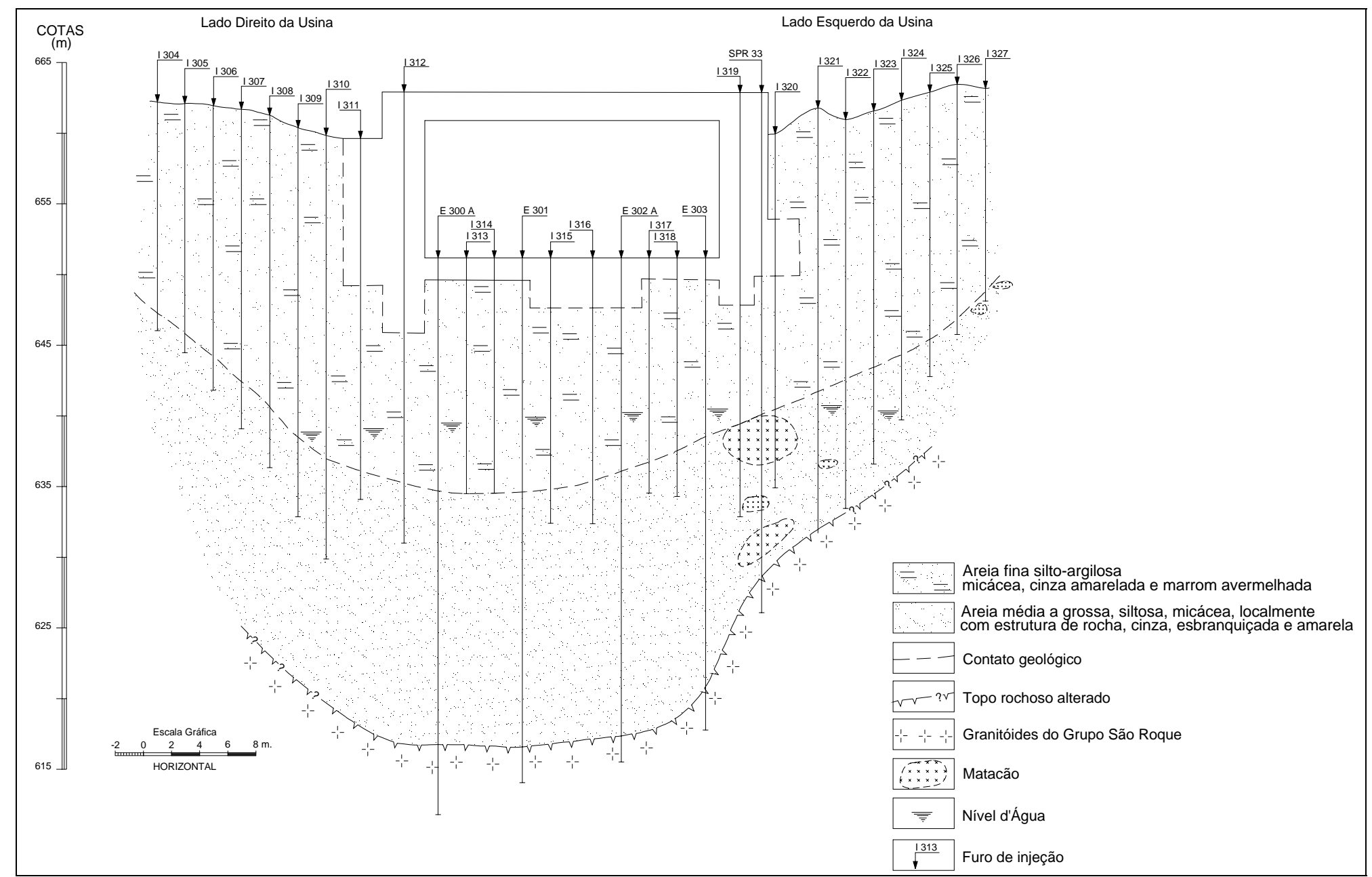

FIGURA 36 - Seção geológica na tomada d'água da Usina de Rasgão. 


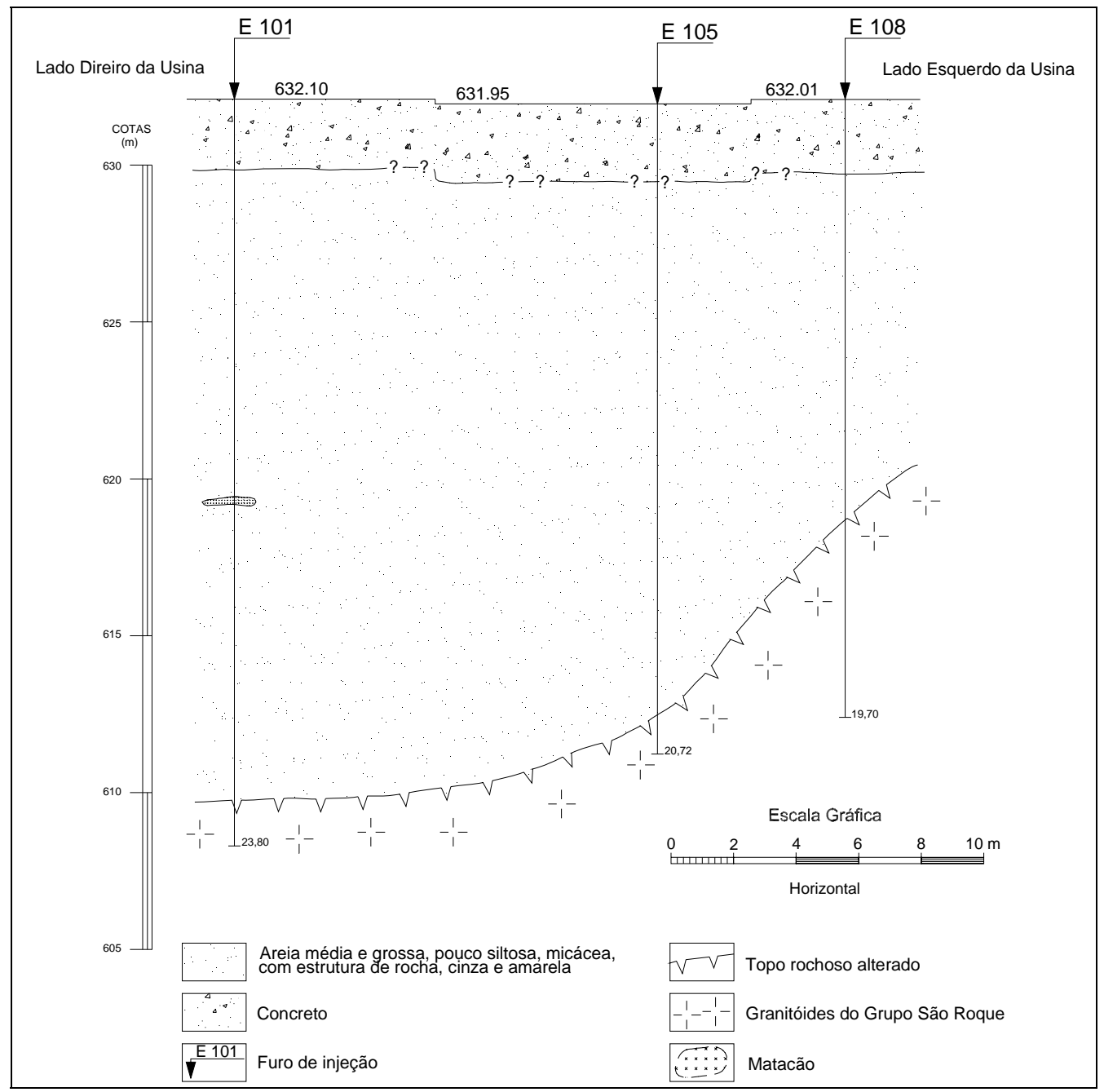

FIGURA 37 - Seção geológica na região da casa de força.

Para melhorar a estabilidade da barragem, foram instalados 61 tirantes dispostos ao longo de uma linha traçada no paramento de jusante da barragem de concreto. Outros 20 tirantes foram instalados nos contrafortes do descarregado de fundo e do vertedouro. Cada tirante foi construído com 12 cordoalhas de aço e protendido com carga de 120 tf.

A campanha de investigação mostrou, ainda, a ocorrência de vazamentos pelo corpo da barragem. Para reduzi-los, foi projetada uma malha de injeção de resina nas trincas e juntas de concretagem, além do revestimento do paramento de montante com argamassa de cimento e pintura com epoxi. Além desses serviços, o projeto contemplou, ainda, a 
recuperação dos taludes do canal de adução e a melhoria das condições do maciço terroso de fundação das estruturas de geração de energia elétrica.

No presente estudo, devido ao seu escopo, foram abordados somente os ensaios e os trabalhos realizados para consolidar e melhorar o maciço de solo situado sob as estruturas da tomada d'água da usina, dos condutos forçados e da casa de força. Foram abordadas também, as atividades realizadas na construção da cortina de vedação para reduzir o fluxo de água pelo maciço terroso de fundação da tomada d'água da usina.

O conjunto de geração é composto, de montante a jusante, pela estrutura de controle das comportas, denominada tomada d'água da usina, dois condutos forçados em concreto e da casa de força que abriga duas unidades geradoras (FIGURA 38). Todo o conjunto está fundado em maciço terroso, constituído de areia fina silto-argilosa e areia média a grossa siltosa, com espessura total variável até pouco mais de $30 \mathrm{~m}$.

A região do conjunto gerador, em 1961, já havia apresentado problemas no terreno de fundação. Na época, foi descoberta percolação de água pelas trincas e juntas das estruturas de concreto dos condutos forçados, que originaram grandes vazios no solo de fundação do conjunto de geração. Devido a este problema, foi necessário realizar reparos nas trincas do concreto e recuperar parte do maciço terroso, obstruindo as cavidades com blocos de rocha e argamassa (MELLO et al., 1990).

Deteriorações nas fundações e estruturas da Usina de Rasgão foram novamente verificadas vinte anos mais tarde, portanto, no início da década de 80. Os condutos forçados, de $36 \mathrm{~m}$ de comprimento e $23 \mathrm{~m}^{2}$ de seção transversal retangular, apresentavam trincas que provocavam a infiltração d'água no terreno de fundação. Os resultados da campanha de investigação realizada, em 1985, indicaram a necessidade de melhorar as condições geotécnicas do terreno de fundação, visando sua estabilização, assim como, recuperar as estruturas de concreto. 


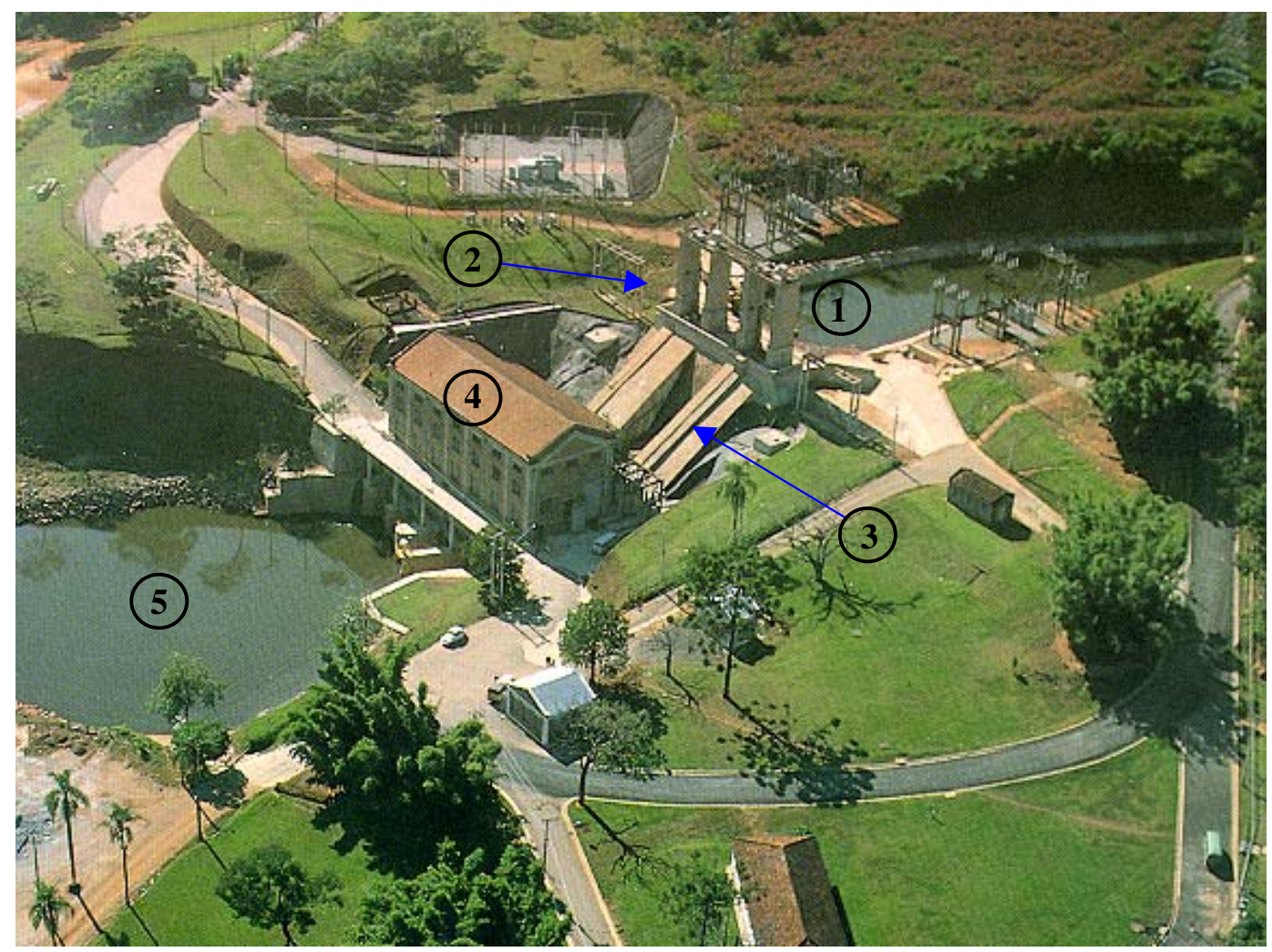

FIGURA 38 - Vista geral do conjunto de geração da Usina de Rasgão. Da direita para a esquerda: (1) canal de adução, (2) tomada d’água da usina, (3) condutos forçados, (4) casa de força e (5) canal de fuga.

É interessante lembrar que nessa época estavam em fase de encerramento os trabalhos para obstruir os canalículos por meio de injeção de solo-cimento na Barragem de Balbina. Estas experiências adquiridas induziram os técnicos da empresa projetista a adotar um tratamento semelhante para o maciço terroso de fundação da Usina de Rasgão. O projeto foi fundamentado na indução de rupturas hidráulicas no maciço, para atingir possíveis vazios existentes e preenchê-los com calda de solo-cimento. Na Usina de Rasgão, realizou-se, ainda, a construção de uma cortina de vedação, empregando-se a mesma técnica do fraturamento hidráulico, com a finalidade de aumentar o caminho de percolação de água pelo maciço, situado sob as estruturas de geração, reduzindo o gradiente hidráulico entre o canal de adução e o canal de fuga, localizado após a casa de força.

\subsection{Características gerais do projeto de tratamento}


O projeto de tratamento do maciço de fundação do conjunto de geração da Usina de Rasgão, excetuando-se as partes relativas à barragem principal e ao canal de adução, foi desenvolvido para atender e resolver, basicamente, dois problemas: a deterioração do maciço de fundação por piping e as grandes percolações.

A decisão em consolidar o maciço terroso, sobre o qual estão fundadas a tomada d'água da usina, os condutos forçados e a casa de força, pelo método de injeção por “clacagem”, ou seja, por meio do fraturamento hidráulico do maciço terroso, deve-se aos resultados positivos da análise técnico-econômica e, principalmente, à facilidade em preencher vazios situados a certa distância dos furos de injeção. Convém destacar que para recuperar as fundações foram estudados outros métodos, como a construção de colunas do tipo jet grouting, diafragma plástico, entre outros que foram descartados por diversos motivos. Entre eles, o principal foi o custo muito elevado dessas técnicas em relação ao do fraturamento hidráulico. Outras razões levantadas foram: disposição desfavorável das estruturas da usina e espaço restrito para deslocamento de grandes equipamentos devido às características topográficas locais.

Ao longo do eixo longitudinal da tomada d’água da usina, foi projetada uma cortina de vedação composta por furos verticais. Estes furos foram dispostos em três linhas paralelas, como mostra a FIGURA 39. Nesta figura, o número de identificação dos furos que compõem a cortina inicia-se em 300 e é precedido por uma letra que qualifica o tipo de atividade prevista no furo (I - injeção; E - exploratório; C- controle e V - eventuais).

No projeto de tratamento de consolidação (FIGURA 39), os furos verticais foram dispostos em malha de aproximadamente 3 x 3 m e distribuídos sob as estruturas de concreto. Ao redor dos condutos forçados e sob parte da casa de força, foram projetados furos inclinados, devido às dificuldades de acesso para atingir determinadas áreas da fundação. A numeração dos furos de consolidação inicia-se em 100, sob a casa de força e em 
200, sob os condutos forçados. De forma semelhante aos furos da cortina, o número também é precedido por letras que qualificam o tipo de atividade previsto em projeto.

A profundidade dos furtos verticais de consolidação variou devido às condições geológicas locais, especialmente os furos exploratórios. A profundidade dos furos inclinados variou entre 7 e 9 m, em função da posição do contato concreto/solo.

\subsubsection{Cortina de vedação}

A cortina de vedação é composta por um conjunto de furos posicionados em três linhas paralelas (FIGURA 39), denominadas jusante, montante e central, cujo aspecto geométrico assemelha-se ao tratamento efetuado na Barragem de Balbina (FIGURA 31). Durante os trabalhos de injeção, a linha de jusante ficou sendo conhecida por linha primária, a de montante, por linha secundária e a central de linha terciária, devido à seqüência de etapas do processo de injeção.

Ao longo da linha de jusante, foram locados 4 furos exploratórios (E 300, E 301, E 302 e E 303), distanciados de 6 m, 7 m e 6 m (FIGURA 39). Nestes furos, foram realizados os ensaios prévios para determinação do coeficiente de permeabilidade do terreno natural. As profundidades desses furos variaram de $33 \mathrm{~m}$ até $37 \mathrm{~m}$, devido à profundidade do topo rochoso inalterado (FIGURA 40). Encerrada as atividades para determinação do coeficiente de permeabilidade, os furos sofreram processo de injeção de calda de solocimento.

Na FIGURA 39, estão assinalados também 53 furos de injeção, identificados pela letra I, nas duas linhas da cortina de vedação (linha de montante e de jusante). A profundidade desses furos variou de 15 m a 30 m, em função da posição da superfície do maciço rochoso alterado. A distância entre eles foi fixado em 2 m, mas, devido às estruturas da usina, essa distância variou até $3 \mathrm{~m}$. 
FIGURA 39 - Planta geral do tratamento efetuado por injeção de solo-cimento na Usina de Rasgão. 


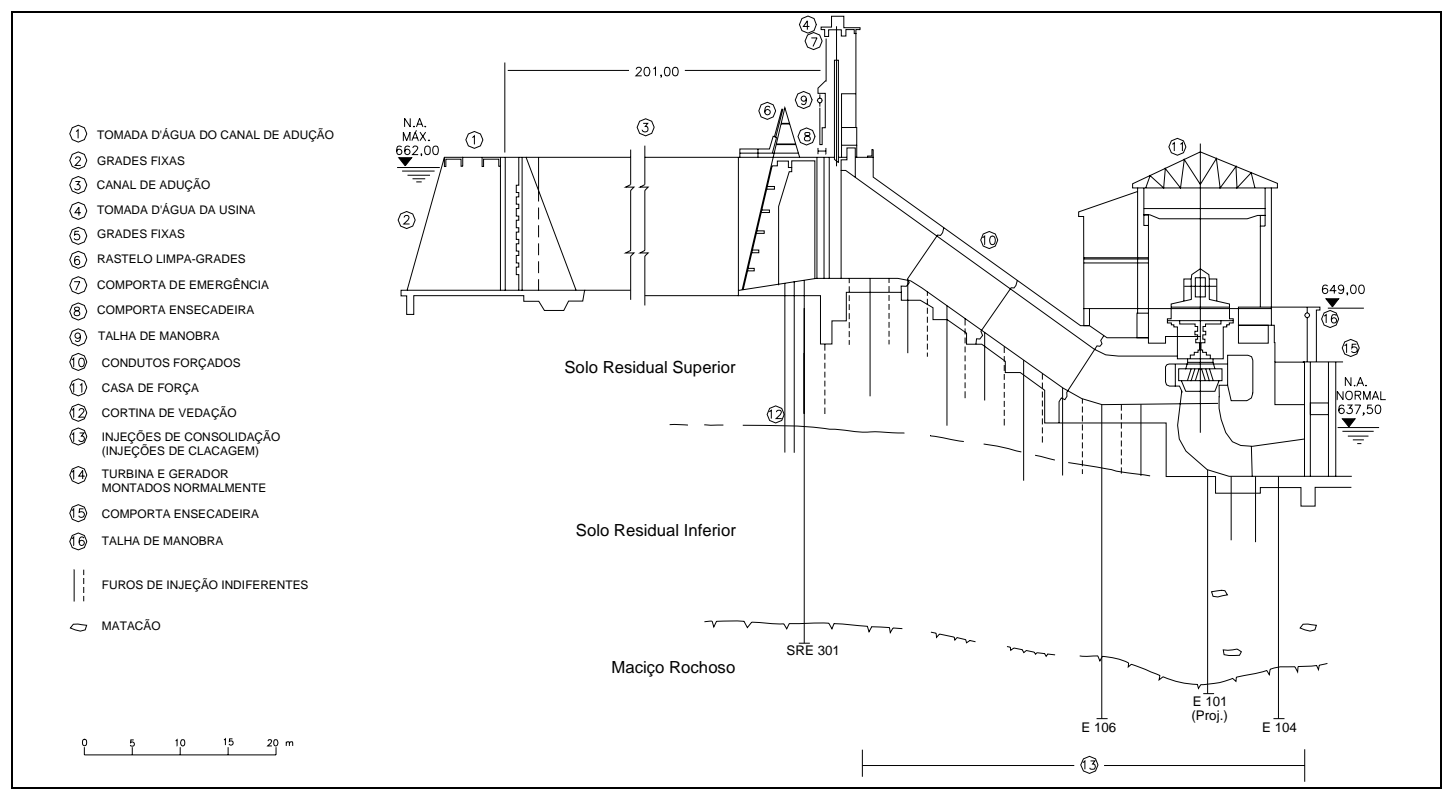

FIGURA 40 - Corte da área dos tratamentos com injeção de solo-cimento.

A linha central da cortina de vedação foi composta por 19 furos verticais, denominados controle e identificados pela letra C. A profundidade desses furos variou entre 15 m e 25 m, de acordo com a localização da superfície do maciço rochoso alterado.

Convém ressaltar que estes furos foram realizados após a conclusão das injeções nas linhas anteriores. Nos furos desta linha, foram realizados ensaios de infiltração para determinar o coeficiente de permeabilidade do terreno após o tratamento. As profundidades dos furos de controle foram estabelecidas, levando-se em consideração aquelas alcançadas pelos furos vizinhos.

Na cortina de vedação, foram previstos também furos eventuais distribuídos ao longo da linha central (ou terciária). A execução desses furos dependia dos resultados obtidos nos ensaios de permeabilidade, executados nos furos de controle. O projeto previa a injeção nos furos eventuais, identificados pela letra V (FIGURA 39), quando o coeficiente de permeabilidade apresentava valor superior a $5 \times 10^{-5} \mathrm{~cm} / \mathrm{s}$.

Na cortina de vedação da Usina de Rasgão foi executado apenas um furo eventual, localizado na ombreira esquerda da tomada d'água da usina, entre os furos C-357 e C-358. 
Como medida de segurança para evitar percolação de água pelo maciço terroso e a formação de possíveis piping, foram escavados quatro poços de drenagem localizados a jusante da cortina de vedação e dos condutos forçados (FIGURA 39). Os dois poços de cada lado dos condutos estão interligados e o possível excesso de água foi direcionado para o canal de fuga da usina. É importante ressaltar que os poços D2 e E2 estão conectados por um dreno horizontal de PCV, com $20 \mathrm{~cm}$ de diâmetro. Esse dreno, revestido com manta de geotêxtil, foi construído para captar possíveis fluxos de água que poderão se instalar sob os condutos forçados, no caso de ocorrer vazamentos pela cortina de vedação.

A seqüência estabelecida para execução do tratamento por injeção na cortina de vedação foi:

- ensaios de infiltração nos quatro furos exploratórios;

- injeção nos furos exploratórios (linha de jusante);

- injeção nos demais furos da linha de jusante;

- injeção nos furos da linha de montante;

- ensaios de infiltração nos furos de controle da linha central;

- injeção nos furos de controle;

- avaliação dos resultados de permeabilidade;

- injeção nos furos eventuais.

A injeção simultânea de dois ou mais furos, localizados na mesma linha de injeção, foi permitida pelo projeto desde que fosse obedecida a distância mínima de $12 \mathrm{~m}$ entre eles. Para distâncias menores que a estabelecida, exigia-se a cura da calda injetada. Essas restrições estão fundamentadas no estudo elaborado por BARRADAS (1985), que tratou da estimativa do alcance das caldas injetadas e nas experiências adquiridas durante o tratamento da Barragem de Balbina. Nesta obra, SANTOS et al. (1985) notaram que, ao injetar furos situados dentro do raio do alcance da injeção, a calda injetada no maciço 
retornava para a superfície pela parede do furo vizinho. Tal fato poderia diminuir a eficiência e a qualidade da injeção.

\subsubsection{Consolidação de fundação}

No projeto de tratamento de consolidação dos condutos forçados e da casa de força, os furos foram diferenciados apenas em exploratórios e de injeção.

Ao longo do eixo dos condutos forçados, foram executados 8 furos exploratórios, identificados pela letra E, nos quais foram realizados os ensaios para determinação do coeficiente de permeabilidade, à semelhança dos ensaios efetuados na cortina de vedação. Outros 10 furos exploratórios também foram dispostos sob a casa de força, cujas profundidades variaram em função do topo rochoso intacto (FIGURA 40).

Distribuídos geometricamente sob os condutos forçados, foram previstos ainda 73 furos de injeção, identificados pela letra I. Sob a casa de força, a quantidade projetada dos furos de injeção foi de 56 unidades.

Cumpre ressaltar que nos trabalhos de consolidação não foram previstos ensaios para determinação do coeficiente de permeabilidade após o tratamento com injeção.

A execução das atividades para o tratamento de consolidação obedeceu à seguinte seqüência:

- ensaios de infiltração nos furos exploratórios;

- injeção nos furos exploratórios;

- injeção nos demais furos.

\subsection{Trabalhos realizados para a injeção de solo-cimento}


A primeira atividade principal visando o tratamento do maciço terroso da Usina de Rasgão foi caracterizar a permeabilidade do terreno natural que serviu de referência para avaliação da injeção. Encerrada a etapa de ensaios prévios de infiltração, tanto na cortina de vedação como na área para consolidação, iniciou-se, imediatamente, o trabalho de injeção nos próprios furos submetidos aos ensaios de infiltração.

É importante ressaltar que, antes de iniciar a campanha de perfuração e injeção no maciço, foram realizados ensaios, em laboratório, dos materiais utilizados na confecção das caldas de solo-cimento, bem como estudos para determinação de traços e caracterização reológica das caldas.

Para realizar estas atividades, foi instalado um laboratório no canteiro de obras, onde foram executados todos os ensaios tecnológicos, exceto os de ruptura de corpos-deprova, que foram realizados no Laboratório de Engenharia Civil de Ilha Solteira da Companhia Energética de São Paulo - CESP.

\subsubsection{Ensaios de permeabilidade}

Os coeficientes de permeabilidade do terreno natural e tratado foram obtidos por meio de ensaios in situ do tipo infiltração a nível constante. Esses ensaios foram executados em furos de sondagens, adotando-se as orientações contidas no Boletim 4 da ABGE (1981). Tais ensaios foram executados, no início da campanha de injeção, ao longo dos furos exploratórios, em trechos descendentes e sucessivos de 3 m, não subseqüentes e separados de $1 \mathrm{~m}$.

Os ensaios de infiltração foram executados em furos de 75 mm de diâmetro que, após cada ensaio, sofreram alargamento, devido à necessidade em posicionar o revestimento para isolar a porção superior do terreno. Tal cuidado foi adotado para permitir 
boa vedação entre a parede do furo e o revestimento, evitando medições incorretas das absorções de água.

Os critérios adotados para execução dos ensaios de infiltração nos furos de controle, localizados na linha central (ou terciária) da cortina de vedação, foram os mesmos critérios estabelecidos para os furos exploratórios.

Nos furos exploratórios, foram executados 65 ensaios de infiltração e nos de controle, 74. Na TABELA 6, foram indicados os resultados obtidos nos ensaios.

\subsubsection{Ensaios em caldas de solo-cimento}

Com a finalidade de verificar o atendimento das exigências do projeto, foi necessário determinar a granulometria dos solos das áreas de empréstimo. No projeto, foi exigido teor de areia inferior a 10\% e isenção de matéria orgânica, respectivamente, para evitar desgaste nos equipamentos de injeção e a baixa resistência da calda endurecida.

Os resultados (TABELA 7) mostraram que os solos das duas áreas de empréstimo apresentavam teores de areia acima do exigido. Em função das características geológicas locais, com presença de rochas granitóides e filitos (quartzosos), portanto, com poucas possibilidades de ocorrência de jazida constituída de solos argilosos, foi necessário decidir pelo uso do solo de uma das áreas investigadas.

Por outro lado, os estudos efetuados por PITTA (1984) permitiram o uso do solo com granulação mais grossa, embora houvesse a possibilidade de ocorrer desgastes nos equipamentos de injeção. Optou-se, então, pelo solo da área de empréstimo denominada EN, pois apresentava granulometria dentro dos limites estabelecidos por PITTA (op. cit.), o que não ocorreu com o solo da área STA, que continha materiais de granulometria maior. 
TABELA 6 - Resultados dos ensaios de infiltração para determinação do coeficiente de permeabilidade do terreno, realizados na Usina de Rasgão.

\begin{tabular}{|c|c|c|c|c|c|c|c|}
\hline \multicolumn{8}{|c|}{ Ensaios de infiltração } \\
\hline \multicolumn{4}{|c|}{ Terreno natural } & \multicolumn{4}{|c|}{ Após injeção } \\
\hline $\begin{array}{l}\text { Número } \\
\text { do furo }\end{array}$ & $\begin{array}{c}\text { Permeabilidade } \\
(\mathrm{cm} / \mathrm{s})\end{array}$ & $\begin{array}{l}\text { Número } \\
\text { do furo }\end{array}$ & $\begin{array}{c}\text { Permeabilidade } \\
(\mathrm{cm} / \mathrm{s})\end{array}$ & $\begin{array}{l}\text { Número } \\
\text { do furo }\end{array}$ & \begin{tabular}{|c|}
$\begin{array}{c}\text { Permeabilidade } \\
(\mathrm{cm} / \mathrm{s})\end{array}$ \\
\end{tabular} & $\begin{array}{l}\text { Número } \\
\text { do furo }\end{array}$ & $\begin{array}{c}\text { Permeabilidade } \\
(\mathrm{cm} / \mathrm{s})\end{array}$ \\
\hline$E-101$ & 3,60E-04 & $E-300$ & $1,10 \mathrm{E}-05$ & $C-357$ & 4,10E-04 & $C-366$ & 2,90E-05 \\
\hline$E-102$ & $3,60 \mathrm{E}-04$ & $E-301$ & 6,10E-05 & $C-357$ & 6,80E-05 & $C-366$ & $2,10 \mathrm{E}-05$ \\
\hline$E-104$ & $1,80 \mathrm{E}-05$ & $E-301$ & $4,60 \mathrm{E}-05$ & C - 358 & 5,30E-05 & $C-366$ & $2,70 \mathrm{E}-05$ \\
\hline E - 104 & $1,50 \mathrm{E}-05$ & $E-301$ & $7,60 \mathrm{E}-05$ & C - 358 & $4,00 \mathrm{E}-05$ & C - 366 & $3,10 \mathrm{E}-05$ \\
\hline$E-105$ & $1,20 \mathrm{E}-04$ & $E-301$ & $5,60 \mathrm{E}-05$ & C - 358 & $8,50 \mathrm{E}-05$ & C - 367 & $1,10 \mathrm{E}-05$ \\
\hline E - 108 & $3,20 \mathrm{E}-03$ & $E-301$ & $9,60 \mathrm{E}-05$ & C - 359 & $1,30 \mathrm{E}-04$ & $C-367$ & $1,10 \mathrm{E}-05$ \\
\hline$E-108$ & $1,60 \mathrm{E}-04$ & $E-301$ & $6,40 \mathrm{E}-05$ & C - 359 & 4,70E-05 & C - 367 & 1,90E-05 \\
\hline E - 109 & 6,50E-05 & $\mathrm{E}-301$ & $2,50 \mathrm{E}-04$ & C - 359 & 4,30E-05 & C - 367 & $1,60 \mathrm{E}-05$ \\
\hline E - 200 & $1,21 \mathrm{E}-03$ & $E-301$ & $2,77 \mathrm{E}-04$ & C - 359 & $5,70 \mathrm{E}-05$ & $C-368$ & $8,30 \mathrm{E}-06$ \\
\hline$E-200$ & $1,60 \mathrm{E}-03$ & $E-301$ & $3,80 \mathrm{E}-04$ & $C-360$ & $3,20 \mathrm{E}-04$ & $C-368$ & $2,70 \mathrm{E}-05$ \\
\hline E - 201 & $1,50 \mathrm{E}-05$ & $E-302$ & $7,30 \mathrm{E}-05$ & $C-360$ & $1,04 \mathrm{E}-04$ & $C-368$ & $1,70 \mathrm{E}-05$ \\
\hline E - 201 & $8,30 \mathrm{E}-05$ & $E-302$ & 5,50E-05 & $C-360$ & $8,40 \mathrm{E}-05$ & $C-368$ & $2,20 \mathrm{E}-05$ \\
\hline E - 201 & $4,80 \mathrm{E}-05$ & $\mathrm{E}-302$ & 5,40E-05 & $C-360$ & 9,10E-06 & C - 369 & $1,80 \mathrm{E}-05$ \\
\hline E - 202 & $4,40 \mathrm{E}-03$ & $E-302$ & $7,10 \mathrm{E}-05$ & $C-360$ & $6,20 \mathrm{E}-05$ & $\mathrm{C}-369$ & $1,00 \mathrm{E}-05$ \\
\hline E - 202 & $7,60 \mathrm{E}-05$ & $E-302$ & $6,60 \mathrm{E}-05$ & $C-361$ & $2,20 \mathrm{E}-04$ & C - 369 & $1,50 \mathrm{E}-05$ \\
\hline E - 202 & 1,50E-04 & $E-302$ & 1,30E-04 & $\mathrm{C}-361$ & $1,20 \mathrm{E}-04$ & C - 369 & $1,30 \mathrm{E}-05$ \\
\hline E - 203 & $2,30 \mathrm{E}-05$ & E - 302 & 3,60E-04 & C - 361 & 5,10E-05 & $\mathrm{C}-370$ & $8,10 \mathrm{E}-06$ \\
\hline E - 203 & $1,30 \mathrm{E}-03$ & $E-302$ & 1,20E-04 & $C-361$ & $4,20 \mathrm{E}-05$ & $C-370$ & 3,50E-06 \\
\hline$E-203$ & $2,10 \mathrm{E}-04$ & $E-302$ & 1,70E-04 & $\mathrm{C}-361$ & 1,90E-05 & $\mathrm{C}-370$ & 6,80E-06 \\
\hline E - 205 & 1,10E-04 & $E-303$ & $3,50 \mathrm{E}-05$ & $C-361$ & $7,60 \mathrm{E}-05$ & $C-370$ & 6,70E-06 \\
\hline E-205 & 1,19E-04 & $E-303$ & 5,30E-05 & $\mathrm{C}-361$ & 1,90E-06 & C - 371 & 3,70E-04 \\
\hline E - 205 & $1,53 \mathrm{E}-04$ & $E-303$ & $1,50 \mathrm{E}-05$ & C - 362 & $8,90 \mathrm{E}-05$ & C - 371 & $1,10 \mathrm{E}-04$ \\
\hline$E-206$ & 4,40E-05 & $E-303$ & 1,50E-04 & $C-362$ & $1,10 \mathrm{E}-05$ & C - 371 & 6,30E-05 \\
\hline E - 206 & $1,60 \mathrm{E}-05$ & $E-303$ & $2,20 \mathrm{E}-05$ & $C-362$ & $1,80 \mathrm{E}-05$ & C - 371 & $4,40 \mathrm{E}-05$ \\
\hline E - 206 & 3,80E-05 & $E-303$ & $2,20 \mathrm{E}-04$ & C - 362 & $1,75 \mathrm{E}-05$ & C - 371 & $1,10 \mathrm{E}-04$ \\
\hline E - 207 & 6,30E-05 & $E-303$ & $2,80 \mathrm{E}-04$ & C - 363 & 9,70E-06 & C - 371 & 4,70E-05 \\
\hline E - 207 & 5,90E-05 & $E-303$ & $2,40 \mathrm{E}-05$ & $C-363$ & $6,80 \mathrm{E}-06$ & $\mathrm{C}-371$ & $2,30 \mathrm{E}-05$ \\
\hline E - 207 & 4,60E-05 & $E-303$ & $2,10 \mathrm{E}-05$ & $C-363$ & 6,30E-05 & C - 372 & $4,20 \mathrm{E}-05$ \\
\hline$E-300$ & 4,30E-05 & & & $C-363$ & $3,30 \mathrm{E}-05$ & C - 372 & $1,20 \mathrm{E}-05$ \\
\hline$E-300$ & $4,40 \mathrm{E}-05$ & & & C - 364 & $5,60 \mathrm{E}-05$ & C - 372 & $4,50 \mathrm{E}-05$ \\
\hline$E-300$ & 5,60E-05 & & & C - 364 & $2,80 \mathrm{E}-05$ & C - 372 & $2,50 \mathrm{E}-05$ \\
\hline$E-300$ & $8,40 \mathrm{E}-05$ & & & $\mathrm{C}-364$ & $2,90 \mathrm{E}-05$ & C - 372 & $5,20 \mathrm{E}-05$ \\
\hline$E-300$ & $1,60 \mathrm{E}-04$ & & & $C-364$ & $3,98 \mathrm{E}-05$ & C - 372 & $1,50 \mathrm{E}-04$ \\
\hline$E-300$ & $1,70 \mathrm{E}-04$ & & & $C-365$ & $1,90 \mathrm{E}-05$ & C - 373 & $1,10 \mathrm{E}-04$ \\
\hline$E-300$ & 6,70E-04 & & & $C-365$ & $1,50 \mathrm{E}-05$ & C - 373 & 3,60E-05 \\
\hline$E-300$ & $2,60 \mathrm{E}-04$ & & & $C-365$ & $2,60 \mathrm{E}-05$ & C - 373 & $2,90 \mathrm{E}-05$ \\
\hline$E-300$ & $8,50 \mathrm{E}-05$ & & & $C-365$ & $2,60 \mathrm{E}-05$ & C - 373 & $3,50 \mathrm{E}-05$ \\
\hline
\end{tabular}

Na FIGURA 41, são apresentadas as determinações efetuadas em laboratório, bem como os limites estabelecidos por PITTA (op. cit.). Ressalta-se que a exploração da jazida EN ocorreu no trecho compreendido entre 1 e $3 \mathrm{~m}$ de profundidade, e o solo argiloso foi estocado em um galpão coberto e protegido com lona plástica, para evitar a secagem e a formação de torrões trazendo dificuldades para a desagregação do solo.

Cumpre destacar que os ensaios laboratoriais foram sistematicamente realizados, em especial para determinação da umidade do solo, para manter a qualidade e o traço das caldas. 
TABELA 7 - Resultados dos ensaios realizados nos solos das áreas de empréstimo denominadas STA e EN.

\begin{tabular}{|c|c|c|c|c|c|c|c|c|c|c|c|c|c|c|c|c|}
\hline \multirow{2}{*}{\multicolumn{4}{|c|}{ Dados da amostra }} & \multirow{5}{*}{ Material } & \multirow{3}{*}{\multicolumn{3}{|c|}{$\begin{array}{c}\text { Limites } \\
\text { de } \\
\text { Atterberg } \\
\end{array}$}} & \multirow{5}{*}{$\begin{array}{c}\text { Massa } \\
\text { eespecífica } \\
\text { real } \\
\text { dos grãos }\end{array}$} & \multicolumn{6}{|c|}{ Granulometria - \% } & $\mathrm{MF}$ & -33 \\
\hline & & & & & & & & & & & & Arei & & Pedre- & Umidade & Densidad \\
\hline & & Profu & didade & & & & & & Argila & Silte & Fina & Média & Grossa & gulho & & seca \\
\hline F uro & $\mathrm{N}^{\circ}$ & & & & L. L. & L.P. & I. P. & & & & Diâm & tro em & (mm) & & ótima & máxima \\
\hline & & Inicial & Final & & $\%$ & $\%$ & $\%$ & & 0,005 & 0,05 & 0,42 & 2,0 & 4,8 & & $\%$ & $\mathrm{~g} / \mathrm{cm} 3$ \\
\hline STA & 01 & 0,20 & 1,20 & Solo Residual & 56 & 29 & 27 & 2,74 & 49 & 16 & 22 & 12 & 1 & & 20,0 & 1,657 \\
\hline & 02 & 1,20 & 3,00 & $\begin{array}{l}\text { Solo Residual } \\
\end{array}$ & 38 & 23 & 15 & 2,77 & 34 & 30 & 22 & 13 & 1 & & 16,5 & 1,757 \\
\hline & 03 & 3,00 & 4,00 & $\begin{array}{l}\text { Solo Residual } \\
\end{array}$ & 36 & 23 & 13 & 2,76 & 31 & 27 & 25 & 15 & 1 & 1 & 15,7 & 1,777 \\
\hline & 04 & 4,00 & 5,00 & Solo Residual & 40 & 25 & 15 & 2,75 & 39 & 24 & 22 & 14 & 1 & & 17,1 & 1,757 \\
\hline & 05 & \begin{tabular}{|l|l|}
5,00 \\
\end{tabular} & 6,00 & Solo Residual & 38 & 24 & 14 & 2,75 & 34 & 26 & 23 & 17 & & & 17,2 & 1,760 \\
\hline & 06 & 6,00 & 7,00 & $\begin{array}{l}\text { Solo Residual } \\
\end{array}$ & 39 & 23 & 16 & 2,70 & 30 & 27 & 20 & 21 & 1 & 1 & 15,7 & 1,795 \\
\hline & & & & & & & & & & & & & & & & \\
\hline \begin{tabular}{l|l} 
STA & 2 \\
\end{tabular} & \begin{tabular}{|l|l|}
2 & 01 \\
\end{tabular} & 0,00 & 1,50 & Solo Residual & 64 & 36 & 28 & 2,74 & 62 & 14 & 13 & 10 & 1 & & 24,4 & 1,534 \\
\hline & 02 & 1,50 & 3,50 & $\begin{array}{l}\text { Solo Residual } \\
\end{array}$ & 55 & 34 & 21 & 2,75 & 49 & 26 & 15 & 9 & 1 & & 21,1 & 1,637 \\
\hline & 03 & \begin{tabular}{|l|l|}
3,50 \\
\end{tabular} & 4,50 & \begin{tabular}{|l|l} 
Solo Residual \\
\end{tabular} & 48 & 30 & 18 & 2,76 & 36 & 32 & 20 & 12 & & & 20,0 & 1,646 \\
\hline & 04 & $\begin{array}{l}4,50 \\
\end{array}$ & 5,50 & $\begin{array}{l}\text { Solo Residual } \\
\end{array}$ & 47 & 29 & 18 & 2,79 & 35 & 32 & 22 & 11 & & & 17,6 & 1,676 \\
\hline & 05 & 5,50 & 6,50 & $\begin{array}{l}\text { Solo Residual } \\
\end{array}$ & 47 & 27 & 20 & 2,76 & 28 & 33 & 20 & 18 & 1 & & 17,8 & 1,692 \\
\hline & 06 & 6,50 & 7,00 & $\begin{array}{l}\text { Solo Residual } \\
\end{array}$ & $\begin{array}{ll}47 \\
\end{array}$ & 28 & 19 & 2,76 & 35 & 30 & 21 & 13 & 1 & & 19,5 & 1,659 \\
\hline & & & & & & & & & & & & & & & & \\
\hline STA & \begin{tabular}{|l|l|}
3 & 01 \\
\end{tabular} & 0,20 & 1,00 & $\begin{array}{l}\text { Solo Residual } \\
\end{array}$ & 54 & 28 & 26 & 2,74 & 47 & 18 & 22 & 12 & 1 & & 19,6 & - \\
\hline & 02 & 1,00 & 2,00 & Solo Residual & 42 & 27 & 15 & 2,74 & 32 & 29 & 25 & 13 & 0 & 1 & 17 & - \\
\hline & 03 & 2,00 & 3,00 & $\begin{array}{l}\text { Solo Residual } \\
\end{array}$ & 44 & 31 & 13 & 2,71 & 34 & 28 & 29 & 19 & & & 15 & - \\
\hline & 04 & 3,00 & 4,00 & $\begin{array}{l}\text { Solo Residual } \\
\end{array}$ & 41 & 20 & 15 & 2,72 & 21 & 29 & 27 & 22 & 1 & & 13,7 & - \\
\hline & 05 & 4,00 & 5,00 & $\begin{array}{l}\text { Solo Residual } \\
\end{array}$ & 43 & 26 & 17 & 2,73 & 22 & 26 & 27 & 23 & 2 & & 13,5 & - \\
\hline & 06 & 5,00 & 6,00 & Solo Residual & 39 & 26 & 13 & 2,75 & 15 & 28 & 31 & 23 & 3 & & 13,5 & - \\
\hline & 07 & 6,00 & 7,00 & $\begin{array}{l}\text { Solo Residual } \\
\end{array}$ & 36 & 24 & 12 & 2,74 & 17 & 24 & 28 & 30 & 1 & & 13,3 & - \\
\hline & & & & & & & & & & & & & & & & \\
\hline EN & \begin{tabular}{l|l|}
1 & 01 \\
\end{tabular} & 0,00 & 1,00 & $\begin{array}{l}\text { Solo Residual } \\
\end{array}$ & 43 & 24 & 19 & 2,75 & 38 & 23 & 20 & 10 & 9 & & 18,6 & 1,734 \\
\hline & 02 & 1,00 & 2,00 & $\begin{array}{l}\text { Solo Residual } \\
\end{array}$ & 39 & 28 & 11 & 2,75 & 34 & 27 & 26 & 13 & & & 16,9 & 1,756 \\
\hline & 03 & 2,00 & 3,00 & $\begin{array}{l}\text { Solo Residual } \\
\end{array}$ & 40 & 29 & 11 & 2,74 & 32 & 28 & 24 & 16 & & & 18,2 & 1,726 \\
\hline & 04 & 3,00 & 4,00 & Solo Residual & 41 & 22 & 19 & 2,71 & 38 & 26 & 25 & 11 & & & 17,5 & 1,750 \\
\hline & 05 & 4,00 & 5,00 & $\begin{array}{l}\text { Solo Residual } \\
\end{array}$ & 37 & 20 & 17 & 2,71 & 29 & 28 & 28 & 14 & 1 & & 17,0 & 1,763 \\
\hline & 06 & 5,00 & 6,00 & Solo Residual & 39 & 21 & 18 & 2,71 & 24 & 29 & 30 & 16 & 1 & & 16,1 & 1,747 \\
\hline & 07 & 6,00 & 7,00 & Solo Residual & 39 & 23 & 16 & 2,76 & 27 & 34 & 29 & 10 & & & 17,5 & 1,715 \\
\hline & 08 & 7,00 & 8,00 & $\begin{array}{l}\text { Solo Residual } \\
\end{array}$ & 44 & 23 & 21 & 2,76 & 35 & 33 & 21 & 11 & & & 18,6 & 1,708 \\
\hline & 09 & 8,00 & 9,00 & Solo Residual & 39 & 22 & 17 & 2,73 & 30 & 32 & 26 & 12 & & & 16,3 & 1,733 \\
\hline & 10 & 9,00 & 10,00 & $\begin{array}{l}\text { Solo Residual } \\
\end{array}$ & 40 & 26 & 14 & 2,74 & 31 & 28 & 27 & 14 & & & 16,0 & 1,762 \\
\hline & 11 & 10,00 & 11,00 & Solo Residual & 40 & 23 & 12 & 2,73 & 24 & 28 & 29 & 19 & & & 17,6 & 1,744 \\
\hline & 12 & 11,00 & 12,00 & $\begin{array}{l}\text { Solo Residual } \\
\end{array}$ & 38 & 26 & 12 & 2,73 & 23 & 28 & 29 & 20 & & & 17,3 & 1,750 \\
\hline $\mathrm{EN} / 2$ & \begin{tabular}{l|l|l}
2 & 01
\end{tabular} & 0,00 & 1,00 & Solo Residual & 44 & 30 & 13 & 2,74 & 36 & 29 & 19 & 16 & & & 192, & 1,674 \\
\hline & 02 & 1,00 & 2,00 & Solo Residual & 46 & 26 & 20 & 2,73 & 30 & 38 & 18 & 14 & & & 19,0 & 1,674 \\
\hline & 03 & \begin{tabular}{|l|r|} 
& 2,00 \\
\end{tabular} & 3,00 & $\begin{array}{l}\text { Solo Residual } \\
\end{array}$ & 41 & 31 & 10 & 2,76 & 27 & 38 & 24 & 11 & & & 19,8 & 1,671 \\
\hline & 04 & 3,00 & 4,00 & Solo Residual & 41 & 23 & 18 & 2,74 & 26 & 34 & 28 & 12 & & & 19,2 & 1,676 \\
\hline & 05 & \begin{tabular}{|l|l} 
& 4,00 \\
\end{tabular} & 5,00 & Solo Residual & 40 & 29 & 11 & 2,74 & 30 & 31 & 26 & 12 & 1 & & 18,3 & 1,726 \\
\hline & 06 & \begin{tabular}{|l|l|}
5,00 \\
5
\end{tabular} & 6,00 & Solo Residual & 43 & 28 & 15 & 2,75 & 35 & 31 & 19 & 14 & 1 & & 18,0 & 1,724 \\
\hline & 07 & 6,00 & 7,00 & $\begin{array}{l}\text { Solo Residual } \\
\end{array}$ & 39 & 22 & 17 & 2,73 & 23 & 28 & 35 & 14 & & & 18,0 & 1,716 \\
\hline & 08 & 7,00 & 8,00 & Solo Residual & 40 & 23 & 17 & 2,77 & 26 & 25 & 32 & 17 & & & 17,0 & 1,758 \\
\hline & 09 & 8,00 & 9,00 & $\begin{array}{l}\text { Solo Residual } \\
\end{array}$ & 38 & 21 & 17 & 2,74 & 29 & 30 & 28 & 13 & & & 17,5 & 1,744 \\
\hline & 10 & 9,00 & 10,00 & $\begin{array}{l}\text { Solo Residual } \\
\end{array}$ & 37 & 27 & 10 & 2,73 & 23 & 32 & 28 & 17 & & & 16,7 & 1,747 \\
\hline & 11 & 10,00 & $\begin{array}{ll}11,00 \\
\end{array}$ & $\begin{array}{l}\text { Solo Residual } \\
\end{array}$ & 38 & 25 & 13 & 2,77 & 32 & 29 & 27 & 12 & & & 17,0 & 1,754 \\
\hline & 12 & 11,00 & 12,00 & $\begin{array}{l}\text { Solo Residual } \\
\end{array}$ & 39 & 22 & 17 & 2,71 & 22 & 29 & 32 & 17 & & & 16,3 & 1,753 \\
\hline & & & & & & & & & & & & & & & & \\
\hline EN & \begin{tabular}{l|l|}
3 & 01 \\
\end{tabular} & 0,00 & 1,00 & $\begin{array}{l}\text { Solo Residual } \\
\end{array}$ & 45 & 28 & 17 & 2,76 & 37 & 26 & 20 & 14 & 1 & 2 & 19,1 & 1,705 \\
\hline & 02 & 1,00 & 2,00 & $\begin{array}{l}\text { Solo Residual } \\
\end{array}$ & 41 & 24 & 17 & 2,77 & 31 & 29 & 23 & 16 & 1 & & 17,4 & 1,729 \\
\hline & 03 & 2,00 & 3,00 & $\begin{array}{l}\text { Solo Residual } \\
\end{array}$ & 41 & 30 & 11 & 2,73 & 30 & 29 & 22 & 18 & 1 & & 17,7 & 1,704 \\
\hline & 04 & 3,00 & 4,00 & $\begin{array}{l}\text { Solo Residual } \\
\end{array}$ & 43 & 25 & 18 & 2,76 & 32 & 28 & 22 & 18 & & & 18,2 & 1,718 \\
\hline & 05 & 4,00 & 5,00 & $\begin{array}{l}\text { Solo Residual } \\
\end{array}$ & 38 & 28 & 10 & 2,75 & 27 & 27 & 28 & 18 & & & 17,5 & 1,731 \\
\hline & 06 & 5,00 & 6,00 & Solo Residual & 42 & 23 & 19 & 2,77 & 35 & 26 & 22 & 17 & & & 16,9 & 1,753 \\
\hline & 07 & 6,00 & 7,00 & $\begin{array}{l}\text { Solo Residual } \\
\end{array}$ & 39 & 22 & 17 & 2,76 & 28 & 28 & 26 & 17 & 1 & & 16,9 & 1,742 \\
\hline & 08 & 7,00 & 8,00 & Solo Residual & 38 & 27 & 11 & 2,77 & 32 & 30 & 26 & 12 & & & 18,2 & 1,730 \\
\hline & 09 & 8,00 & 9,00 & $\begin{array}{l}\text { Solo Residual } \\
\end{array}$ & 36 & 25 & 11 & 2,80 & 33 & 24 & 26 & 16 & 1 & & 15,8 & 1,816 \\
\hline & 10 & 9,00 & 10,00 & Solo Residual & 38 & 27 & 11 & 2,76 & 27 & 25 & 27 & 19 & 2 & & 15,8 & 1,805 \\
\hline & 11 & 10,00 & 11,00 & $\begin{array}{l}\text { Solo Residual } \\
\end{array}$ & 36 & 25 & 11 & 2,76 & 28 & 25 & 28 & 18 & 1 & & 15,4 & 1,803 \\
\hline & 12 & 11,00 & $\begin{array}{ll}12,00 \\
\end{array}$ & $\begin{array}{l}\text { Solo Residual } \\
\end{array}$ & 32 & 23 & 10 & 2,70 & 25 & 25 & 33 & 16 & 1 & & 15,1 & 1,821 \\
\hline & & & & & & & & & & & & & & & & \\
\hline EN & \begin{tabular}{l|l|}
4 & 01 \\
\end{tabular} & 0,00 & 1,00 & $\begin{array}{l}\text { Solo Residual } \\
\end{array}$ & 44 & 32 & 12 & 2,73 & 33 & 32 & 22 & 13 & & & 19,2 & 1,663 \\
\hline & 02 & 1,00 & 2,00 & $\begin{array}{l}\text { Solo Residual } \\
\end{array}$ & 45 & 31 & 14 & 2,71 & 29 & 34 & 24 & 13 & & & 20,4 & 1,640 \\
\hline & 03 & 2,00 & 3,00 & Solo Residual & 49 & 27 & 22 & 2,72 & 26 & 33 & 23 & 18 & & & 18,9 & 1,653 \\
\hline & 04 & 3,00 & 4,00 & $\begin{array}{l}\text { Solo Residual } \\
\end{array}$ & 46 & 31 & 15 & 2,72 & 26 & 34 & 26 & 14 & & & 21,0 & 1,627 \\
\hline & 05 & 4,00 & 5,00 & Solo Residual & 45 & 32 & 13 & 2,74 & 28 & 36 & 23 & 13 & & & 19,3 & 1,656 \\
\hline & 06 & $\begin{array}{l}5,00 \\
5\end{array}$ & 6,00 & Solo Residual & 41 & 30 & 12 & 2,73 & 26 & 36 & 25 & 12 & & & 17,8 & 1,698 \\
\hline & 07 & $\begin{array}{ll} & 6,00 \\
\end{array}$ & 7,00 & Solo Residual & 43 & 23 & 20 & 2,72 & 25 & 31 & 31 & 13 & & & 17,9 & 1,693 \\
\hline
\end{tabular}




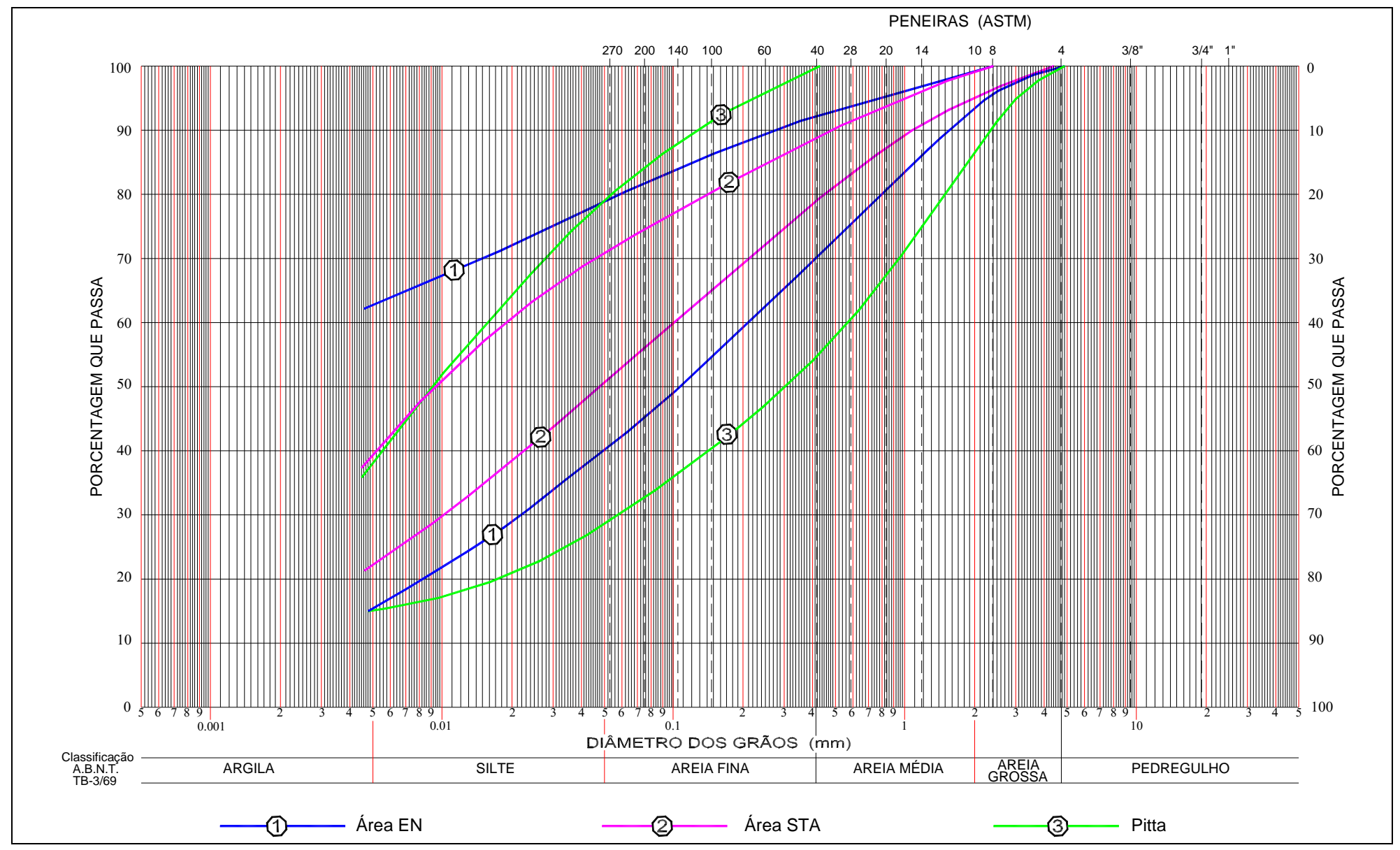

FIGURA 41 - Curvas granulométricas dos materiais das áreas de empréstimo: 1 área EN; 2 área STA e 3 limites estabelecidos por PITTA (1984). 
O projeto do tratamento exigiu que a calda de solo-cimento apresentasse as seguintes características reológicas: fator de sedimentação inferior a 5\%; relação entre solo e água entre 0,40 e 0,70; tempo de escoamento entre 8 e 10 segundos no funil de Marsh com 10 mm de diâmetro; resistência à compressão simples, para a calda da bainha, de $3 \mathrm{MPa}$ ( \pm 0,1 MPa) após 28 dias de cura em ambiente úmido e de $2 \mathrm{MPa}$ aos 28 dias com 95\% de ocorrência entre 1,75 MPa e 2,25 MPa, para o caso da calda de injeção.

Para atender a essas exigências técnicas e devido às características particulares do solo da região da Usina de Rasgão, diferentes daqueles utilizados em Balbina e na Via Anchieta, foi necessário promover estudo no laboratório, visando determinar o melhor traço das caldas para uso na confecção das bainhas e injeções.

Para iniciar os trabalhos, foi utilizado o traço empregado na Barragem de Balbina e, como havia sido previsto, não atendeu às exigências do projeto por tratar-se de solos com características geológicas muito diferentes. Os resultados das determinações da umidade do solo, massa específica da lama e da calda, fluidez e sedimentação dos nove traços de caldas ensaiadas, são apresentados na TABELA 8.

Tomando-se esses traços como base, procurou-se realizar pequenos ajustes nas proporções dos materiais componentes para obter caldas com fator de sedimentação da ordem de 1 a 1,5\% e fluidez no cone de Marsh entre 8 e 9 segundos. Os resultados alcançados são apresentados na TABELA 9, que também mostra os valores de resistência à compressão simples.

Ao final dessa etapa de trabalhos em laboratório, foi decidido eleger dois diferentes traços que atendiam às especificações estabelecidas, cujas proporções relativas em massa, entre cimento, solo e água, foram 1:2:3 e 1:2:4, identificadas na TABELA 9, respectivamente, pelas letras E e F. Pode-se notar que a calda da bainha alcança valor maior de resistência mecânica, nos primeiros 7 dias de idade, em relação à calda escolhida para injeção. Isto se deve à necessidade em abreviar o tempo para o início da injeção. 
As caldas identificadas pelas letras A, B e C foram preteridas por apresentarem valores médios de fluidez no cone de Marsh abaixo do limite estabelecido no projeto. A calda discriminada pela letra D apresentou valor médio de resistência à compressão simples aos 10 dias de idade, relativamente baixo ao comparar com as médias das demais caldas ensaiadas. Ainda que esta calda pudesse atingir o valor mínimo da resistência à compressão aos 28 dias de idade, exigida no projeto, o traço dela foi deixado como reserva para eventual necessidade de se alterar as proporções das caldas escolhidas.

\subsubsection{Perfuração e instalação dos tubos com válvula-manchete}

As perfurações das estruturas de concreto para instalação do tubo de PVC com válvulas-manchete no maciço terroso de fundação, nos trabalhos de tratamento da Usina de Rasgão, foram efetuadas com o auxílio de perfuratrizes rotopercussivas movidas a ar comprimido. Na região próxima da superfície do terreno, o avanço do furo foi conseguido predominantemente com a rotação da haste de perfuração. Nos trechos profundos onde o maciço apresentou maior resistência mecânica, a melhor produção no avanço da perfuração foi obtida pela composição dos movimentos de rotação e percussão das ferramentas de perfuração. Convém salientar que esse método de perfuração apresentou boa eficiência e rapidez na execução dos furos. Um equipamento especial de rotopercussão, denominado martelo de fundo, foi utilizado na perfuração de trechos onde havia matacões em meio ao solo. Este equipamento diferencia-se dos demais pela concepção de seu projeto. Nesta perfuratriz, o dispositivo de percussão está instalado na extremidade inferior da haste e junto à ferramenta de perfuração, contrariamente dos equipamentos comuns. Esse equipamento possibilita, durante a execução dos furos, a introdução de revestimentos telescopáveis, imprescindíveis para atravessar matacões presentes no maciço terroso. 
TABELA 8 - Características médias das caldas preliminares ensaiadas na obra de Rasgão.

\begin{tabular}{|c|c|c|c|c|c|c|c|c|c|c|c|c|}
\hline \multirow[t]{2}{*}{ Amostra } & \multicolumn{3}{|c|}{$\begin{array}{c}\text { Traço com solo } \\
\text { natural (em massa) }\end{array}$} & \multirow{2}{*}{$\begin{array}{l}\text { Umi- } \\
\text { dade } \\
\text { (\%) }\end{array}$} & \multicolumn{3}{|c|}{$\begin{array}{c}\text { Traço com solo seco } \\
\text { (em massa) }\end{array}$} & \multirow[t]{2}{*}{$S / A$} & \multicolumn{2}{|c|}{ Massa específica $\left(\mathrm{kg} / \mathrm{m}^{3}\right)$} & \multirow{2}{*}{$\begin{array}{c}\text { Sedimentação } \\
\text { (\%) }\end{array}$} & \multirow{2}{*}{$\begin{array}{c}\text { Fluidez } \\
\text { (s) }\end{array}$} \\
\hline & Cim & Solo & Água & & Cim & Solo & Água & & Lama & Calda & & \\
\hline 1 & 1 & 2,25 & 5,00 & 25,0 & 1 & 1,70 & 5,60 & 0,30 & - & 1290 & 4,0 & 7,0 \\
\hline 2 & 1 & 3,00 & 3,00 & 18,0 & 1 & 2,46 & 3,54 & 0,69 & - & 1470 & 1,0 & 7,0 \\
\hline 3 & 1 & 3,00 & 4,00 & 22,0 & 1 & 2,34 & 4,66 & 0,50 & - & 1290 & 4,0 & 7,0 \\
\hline 4 & 1 & 3,12 & 5,12 & 25,0 & 1 & 2,34 & 5,90 & 0,40 & - & 1240 & - & 7,0 \\
\hline 5 & 1 & 1,00 & 2,00 & 20,0 & 1 & 0,80 & 2,20 & 0,36 & - & 1320 & 24,0 & 6,0 \\
\hline 6 & 1 & 2,50 & 2,50 & 20,0 & 1 & 2,00 & 3,00 & 0,67 & - & 1500 & 1,0 & 7,0 \\
\hline 7 & 1 & 2,50 & 5,45 & 20,0 & 1 & 2,00 & 6,00 & 0,33 & 1090 & 1210 & 2,0 & 6,0 \\
\hline 8 & 1 & 2,50 & 9,50 & 20,0 & 1 & 2,00 & 5,00 & 0,40 & 1160 & 1260 & 1,0 & 6,0 \\
\hline 9 & 1 & 2,60 & 3,40 & 22,9 & 1 & 2,00 & 4,00 & 0,50 & 1300 & 1380 & 1,5 & 7,7 \\
\hline
\end{tabular}

Cim - cimento; S/A - relação solo/água; Fluidez com cone de Marsh, diâmetro de 10 mm.

TABELA 9 - Valores médios dos parâmetros das caldas ensaiadas na obra de Rasgão.

\begin{tabular}{|c|c|c|c|c|c|c|c|c|c|c|c|c|c|}
\hline \multirow{2}{*}{ Amostra } & \multicolumn{3}{|c|}{ Traço em massa } & \multirow{2}{*}{$S / A$} & \multicolumn{2}{|c|}{ Massa específica $\left(\mathrm{kg} / \mathrm{m}^{3}\right)$} & \multirow{2}{*}{$\begin{array}{c}\text { Sedimentação } \\
\text { (\%) }\end{array}$} & \multirow{2}{*}{$\begin{array}{c}\text { Fluidez } \\
\text { (s) }\end{array}$} & \multicolumn{5}{|c|}{ Resistência à compressão simples (MPa) } \\
\hline & Cim & Solo & Água & & Lama & Calda & & & 07 dias & 08 dias & 10 dias & 21 dias & 28 dias \\
\hline $\bar{A}$ & 1 & 2,05 & 2,95 & 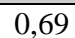 & - & 1500 & - & 7,0 & - & - & 0,35 & - & - \\
\hline B & 1 & 2,50 & 4,00 & 0,63 & 1290 & 1430 & 0,5 & 7,8 & - & - & 0,20 & 0,70 & - \\
\hline $\mathrm{C}$ & 1 & 2,50 & 5,50 & 0,45 & 1150 & 1250 & 1,0 & 6,0 & - & - & 0,70 & - & - \\
\hline $\mathrm{D}$ & 1 & 2,00 & 5,00 & 0,40 & 1130 & 1320 & 1,0 & 8,0 & - & - & 0,20 & - & - \\
\hline E & 1 & 2,00 & 3,00 & 0,67 & 1330 & 1560 & 1,2 & 8,8 & 0,97 & - & 0,76 & - & 0,86 \\
\hline $\mathrm{F}$ & 1 & 2,00 & 4,00 & 0,50 & 1280 & 1400 & 1,5 & 8,6 & 0,47 & 0,47 & 0,47 & - & 0,57 \\
\hline
\end{tabular}

Cim - cimento; S/A - relação solo/água; Fluidez com cone de Marsh, diâmetro de $10 \mathrm{~mm}$; E - calda utilizada nas bainhas; F - calda utilizada nas injeções. 
Imediatamente após a conclusão de cada furo, com 3” de diâmetro, foram instalados tubos de PVC com válvulas-manchete, posicionados a cada metro. Em seguida, o espaço anelar entre o tubo e a parede do furo foi preenchido com calda de solo-cimento, de acordo com o traço definido para a calda da bainha. Para evitar possíveis falhas no preenchimento, a calda foi introduzida no sentido ascendente, ou seja, da primeira manchete, situada na extremidade inferior da tubulação, até extravasar na superfície do terreno.

Na TABELA 9, são apresentados os valores médios dos parâmetros reológicos, bem como o traço da calda da bainha, identificada pela letra E.

\subsubsection{Injeção}

A injeção no maciço foi iniciada após a cura da calda da bainha, que ocorreu pelo menos 5 dias após sua confecção. A abertura das válvulas-manchete foi conseguida aplicando-se pressões crescentes até a ruptura da válvula. Este processo de abertura foi realizado com a própria calda de injeção, identificada pela letra F na TABELA 9. Nesta tabela, são apresentadas as proporções dos materiais utilizados para fabricação da calda, bem como os valores médios dos parâmetros reológicos obtidos nos ensaios de laboratório.

A introdução da calda na fratura hidráulica foi realizada em baixa velocidade, da ordem de 25 l/min, para evitar o regime turbulento no fluido, conforme havia sido alertado no estudo realizado por CRUZ (prelo). Para velocidade de até $60 \ell / \mathrm{min}$, como foi executada a injeção na fundação da Barragem de Balbina, BARRADAS (1985) também demonstrou que a calda de solo-cimento tem comportamento laminar. Esse autor comprovou também que a perda de carga variou linearmente com a velocidade.

As pressões de iniciação da ruptura da bainha e do maciço variaram, predominantemente, entre 2 e $3 \mathrm{MPa}$. Ocasionalmente, foram observados valores maiores, que atingiram até $10 \mathrm{MPa}$. As pressões de injeção exibiram valor médio menor, em torno de 0,8 MPa, e os valores máximos, excepcionalmente, superaram 2 MPa. 
A injeção em cada manchete foi encerrada após atingir o volume de calda de solo-cimento de $200 \ell$, estabelecido em projeto. O consumo de calda e as pressões aplicadas em cada válvula-manchete, nos furos da cortina de vedação e na consolidação das estruturas, são apresentados, respectivamente, nos ANEXOS A e B.

Problemas na ruptura das bainhas foram encontrados na região do maciço onde ocorrem núcleos rígidos de rocha alterada e matacões, principalmente nas proximidades do maciço rochoso. Algumas válvulas, ainda que submetidas a pressões que ultrapassaram 10 MPa, não foram rompidas. A causa desse problema foi atribuída à alta resistência do maciço circundante às válvulas, estando relacionada à presença de núcleos rígidos de rocha alterada ou de matacões.

Após o encerramento da campanha de injeção de vedação e consolidação, os trabalhos foram prosseguidos para avaliação da eficiência do tratamento efetuado. É importante registrar que esse tipo de trabalho foi realizado apenas na cortina de vedação, onde foram executados ensaios de infiltração, antes e depois do tratamento com injeção.

A avaliação visual da injeção foi feita por meio de mapeamentos das paredes dos poços de drenagem, que fazem parte do sistema de segurança para captação de eventuais vazamentos na cortina de vedação (FIGURA 39). São poços com seção quadrada de 4 x 4 m e profundidade de $12 \mathrm{~m}$, que se transformaram em verdadeiros poços de inspeção visual das injeções efetuadas. A área total das paredes e dos pisos dos quatro poços é de $256 \mathrm{~m}^{2}$.

\subsection{Testes realizados na cortina de vedação e no campo de prova}

Além dos estudos do traço das caldas utilizadas no tratamento do maciço terroso da Usina de Rasgão, foi aproveitada a oportunidade, em concordância com a proprietária da obra, para realizar outras pesquisas, durante e após a etapa de injeção na cortina de vedação. Parte dos furos da cortina foram submetidos a testes para avaliar os acréscimos que ocorrem na pressão de injeção na segunda fase de injeção (reinjeção). Outro ensaio foi o estudo do 
comportamento das pressões de iniciação da ruptura do maciço e de injeção durante o processo do fraturamento hidráulico, bem como ao longo do ciclo de propagação das fraturas induzidas.

Outro teste realizado na obra de Rasgão foi o ensaio geofísico do tipo crosshole, realizado antes e após a injeção, para avaliar a eficiência do tratamento. Esse ensaio foi realizado em um campo de prova situado na vizinhança do canal de adução. Ainda neste local, foram promovidos testes com corantes nas caldas de injeção, para análise de possível relação entre as fraturas.

É importante realçar que estes testes e ensaios tiveram como objetivo principal a contribuição na melhoria dos critérios estabelecidos no projeto de injeção, assim como oferecer ao meio técnico a sugestão do ensaio geofísico do tipo crosshole para análise da eficiência da injeção.

\subsubsection{Variação das pressões em diferentes fases de injeção}

Para analisar as variações que podem ocorrer nas pressões de iniciação da ruptura do maciço $(\mathrm{Pr})$ e de injeção $(\mathrm{Pi})$ da segunda fase em relação às da primeira, foram realizadas reinjeções (injeção em duas fases numa mesma manchete) em 110 válvulasmanchete de 39 furos localizados na cortina de vedação.

A segunda fase de injeção foi feita 7 dias após a conclusão da injeção da primeira fase, tempo necessário para que a calda injetada da fase anterior adquirisse uma resistência mínima e próxima do maciço circundante, avaliado em torno de 0,2 MPa. Esse cuidado foi tomado para evitar que a calda inconsolidada da primeira fase pudesse interferir nos valores das pressões da reinjeção.

Outro zelo para executar esse ensaio foi o trabalho de retirar a calda da primeira fase de injeção que permaneceu no tubo de PVC. Esse trabalho de limpar o tubo, foi feito por meio de lavagem com água e ar comprimido, 3 horas após concluída a injeção. 
A análise efetuada do comportamento e as variações das pressões são apresentadas no capítulo seguinte desta pesquisa. Os valores das pressões medidas nas duas fases de injeção, a identificação dos furos e a localização em profundidade foram apresentados na TABELA 15 (ver na página 151).

\subsubsection{Fraturamento hidráulico}

Durante o tratamento do maciço, já com a campanha de injeção em pleno andamento, ficou comprovado que o critério estabelecido no projeto para paralisação da injeção impediu, em alguns casos, o preenchimento total das fraturas abertas pelo processo hidráulico. A propósito, este critério foi fundamentado no estudo teórico de BARRADAS (1985), que determinou o volume de $300 \ell$ de calda de solo-cimento por válvula-manchete.

Por esse motivo e também com a finalidade de melhorar a compreensão do processo de fraturamento hidráulico em maciço terroso, foram realizados ensaios em 72 válvulas-manchete de 25 furos, distribuídos nas três linhas da cortina de vedação. Esse ensaio serviu para a obtenção de informações técnicas, relativas ao comportamento das pressões aplicadas no tratamento com injeções, que foram utilizadas no estabelecimento de critérios executivos.

O ensaio consistiu em injetar um determinado volume de calda, desconsiderando-se o limite estabelecido no projeto, e verificar o comportamento da pressão aplicada ao longo do período de injeção. Os registros das pressões foram apresentados no ANEXO E.

No capítulo referente à análise dos resultados, o estudo da variação da pressão foi promovido com auxílio das ferramentas oferecidas pela estatística.

A execução do ensaio de fraturamento hidráulico obedeceu a uma seqüência de atividades, após a perfuração e fixação do tubo com as válvulas-manchete, como segue: 
1. iniciação da ruptura da bainha e do maciço com a calda de injeção;

2. introdução da calda de solo-cimento até a elevação da pressão de injeção, que ocorreu após ultrapassar o volume estabelecido em projeto;

3. manutenção da injeção aplicada até provocar nova ruptura no maciço ou propagação da primeira fratura;

4. injeção da calda de solo-cimento;

5. encerramento da injeção com pressão superior àquela aplicada para introdução da calda.

Ressalta-se que nos testes realizados foram evitadas mudanças de equipamentos e alterações no procedimento executivo e nos traços das caldas empregadas, que pudessem interferir nos resultados.

\subsubsection{Ensaios geofísicos}

Os ensaios geofísicos realizados em um campo de prova na Usina de Rasgão tiveram como objetivo principal a avaliação da eficiência do tratamento por injeção de solocimento. Foram executados os ensaios do tipo crosshole, empregados nas campanhas de investigação de maciços naturais para caracterização geológico-geotécnica. Até o momento, não foram encontradas publicações brasileiras que tratam de sua aplicação para avaliação da eficiência do tratamento por injeção.

O emprego de ensaios geofísicos, porém com o método do radar, foi realizado por REED \& DUSSEAULT (1997). Os autores aplicaram essa técnica para caracterização de dois campos de prova onde foram efetuadas as pesquisas sobre fraturamento hidráulico em maciço terroso.

No campo de prova da Usina de Rasgão, os ensaios geofísicos crosshole serviram para avaliar a eficiência da injeção. Para isso, foram executados em duas etapas distintas: antes e depois do tratamento do terreno. 
Como se tratava de um estudo pioneiro no Brasil, foram realizadas as seguintes atividades principais:

- investigação e caracterização geológico-geotécnica do campo de prova;

- ensaios geofísicos em três pares de furos;

- tratamento com calda de solo-cimento;

- repetição dos ensaios geofísicos nos mesmos furos;

- $\quad$ escavação de uma trincheira ao longo dos furos de injeção;

- análise dos resultados.

A FIGURA 34 mostra a localização do campo de prova em relação às principais estruturas de geração da Usina de Rasgão. A área com 6 m x 4 m localiza-se próximo do local onde foi construída a cortina de vedação. A disposição das sondagens de investigação e dos furos para injeção e levantamento geofísico podem ser vistos no croqui da FIGURA 42.

\subsubsection{Aspectos geológico-geotécnicos do local}

O campo de prova situa-se sobre solos residuais de rochas granitóides. A superfície do topo rochoso inalterado foi detectado a mais de $30 \mathrm{~m}$ de profundidade por sondagens mecânicas. O solo coluvionar que ocorre ao redor do campo de prova é composto por argila siltosa de cor amarelada.

Os trabalhos de investigação geológico-geotécnica do campo de prova foram iniciados pelas sondagens a trado ( $\phi$ 4”) que atingiram profundidades de $12 \mathrm{~m}$. Os perfis das quatro sondagens a trado executadas nos vértices do retângulo do campo de prova são apresentados nas FIGURAS 43 a 46. Após a conclusão dessas perfurações, foram executadas três sondagens a percussão, com profundidades de $12,45 \mathrm{~m}$, ao longo da linha mediatriz maior do retângulo. Os perfis individuais são apresentados nas FIGURAS 47 a 49. 
Estas sondagens revelaram a ocorrência de três camadas de solo (FIGURA 50).

A primeira está localizada na superfície do terreno e é constituída por argila areno-siltosa, laterizada, marrom-avermelhada. Trata-se de uma camada com espessura da ordem de $1 \mathrm{~m}$, no máximo.

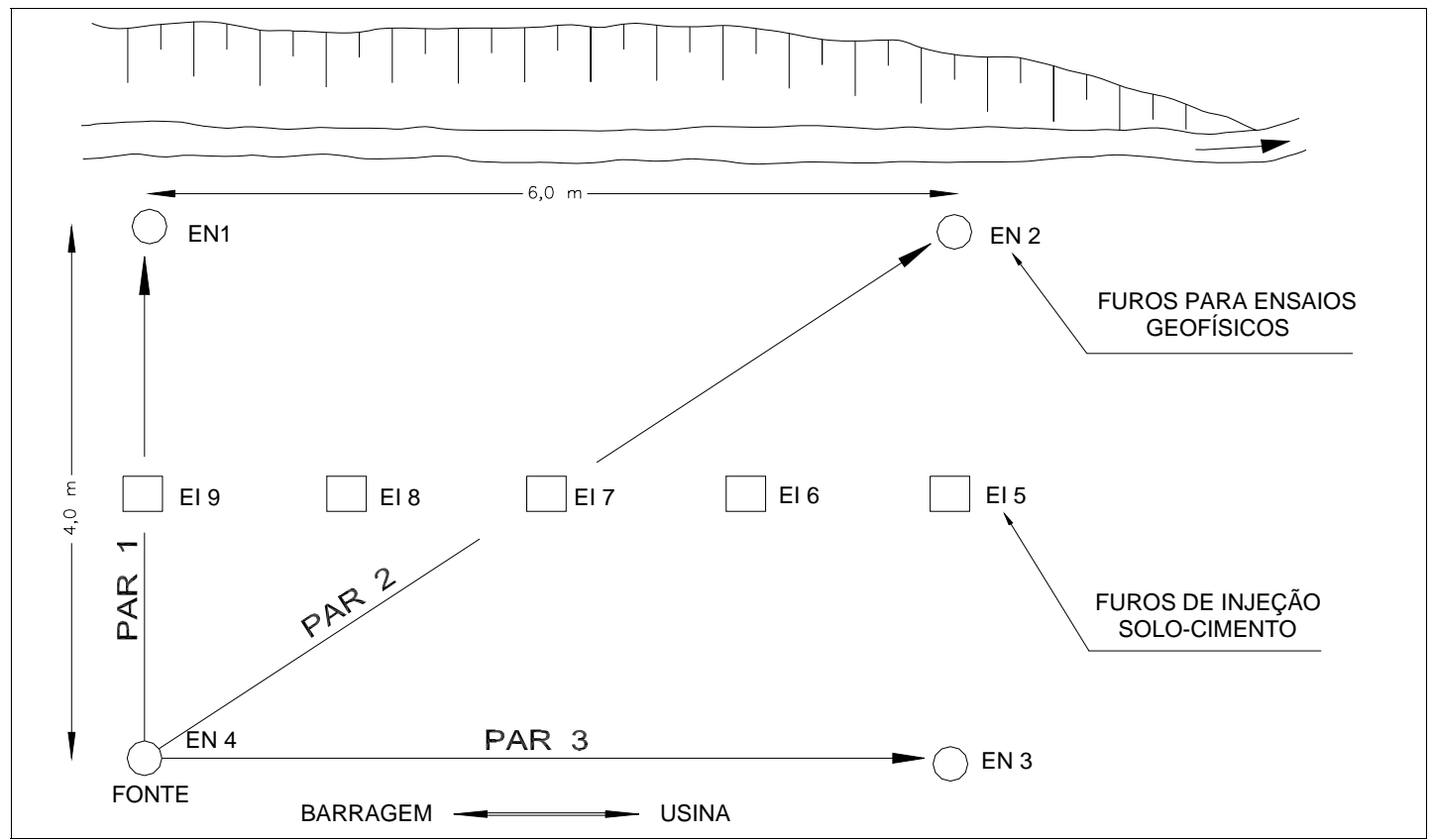

FIGURA 42 - Croqui do campo de prova da Usina de Rasgão. Nos furos EI 5, EI 7 e EI 9, foram realizadas sondagens a percussão com ensaios SPT e injeções; nos furos EI 6 e EI 8, as injeções e os furos EN 1 a EN 4 foram utilizados nos ensaios geofísicos.

As outras duas camadas são mais espessas e foram interceptadas pelas três sondagens a percussão. A camada superior é constituída por silte areno-argiloso, micáceo, cor marrom-avermelhada, com espessura entre 3 e 4 m. Os índices de resistência à penetração obtidos nos ensaios SPT mostraram que os valores são crescentes com a profundidade, variando de 4 até 12 golpes.

Sob estas camadas de solo, ocorre outra composta por areia média siltosa, micácea, contendo estrutura reliquiar da rocha matriz (granitóide), de cores amarelada e acinzentada. Nesta camada, os índices de resistência à penetração, obtidos por meio dos ensaios de SPT, mostraram que os valores variaram entre 14 e 26 golpes. Pelos índices 
apresentados, pode-se afirmar que trata-se de uma camada de areia compacta. O nível d’água não foi atingido pelas sondagens.

Os materiais obtidos nas sondagens a trado foram submetidos aos ensaios de laboratório para determinação granulométrica. Os resultados revelaram os seguintes teores médios: $40 \%$ de areia; $30 \%$ de silte e $30 \%$ de argila.

Deve-se registrar que os materiais utilizados para a confecção das caldas, como o cimento e o solo, foram os mesmos da campanha de injeção da cortina de vedação e de consolidação de fundações da usina. 


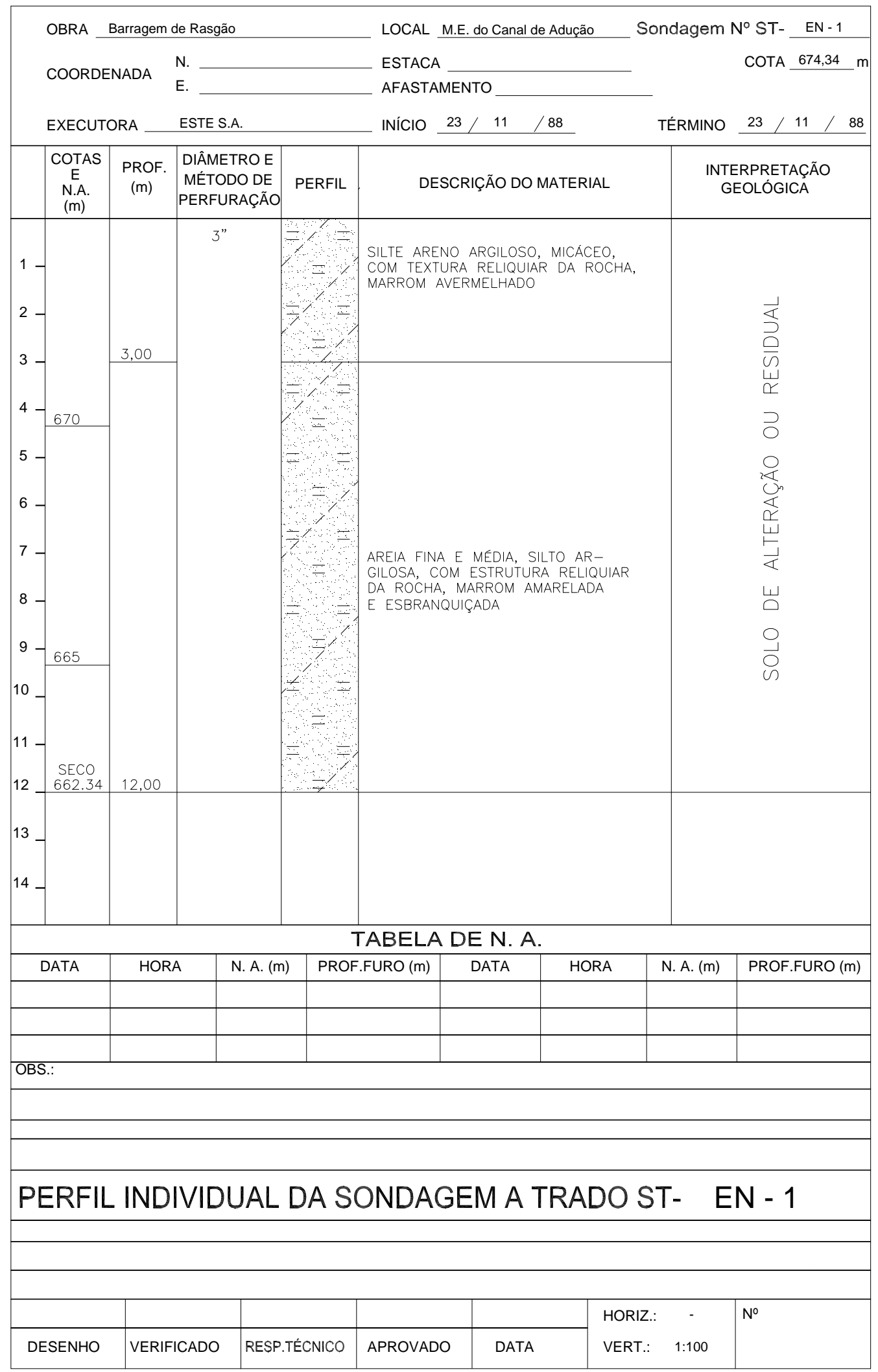

FIGURA 43 - Perfil individual de sondagem a trado. 


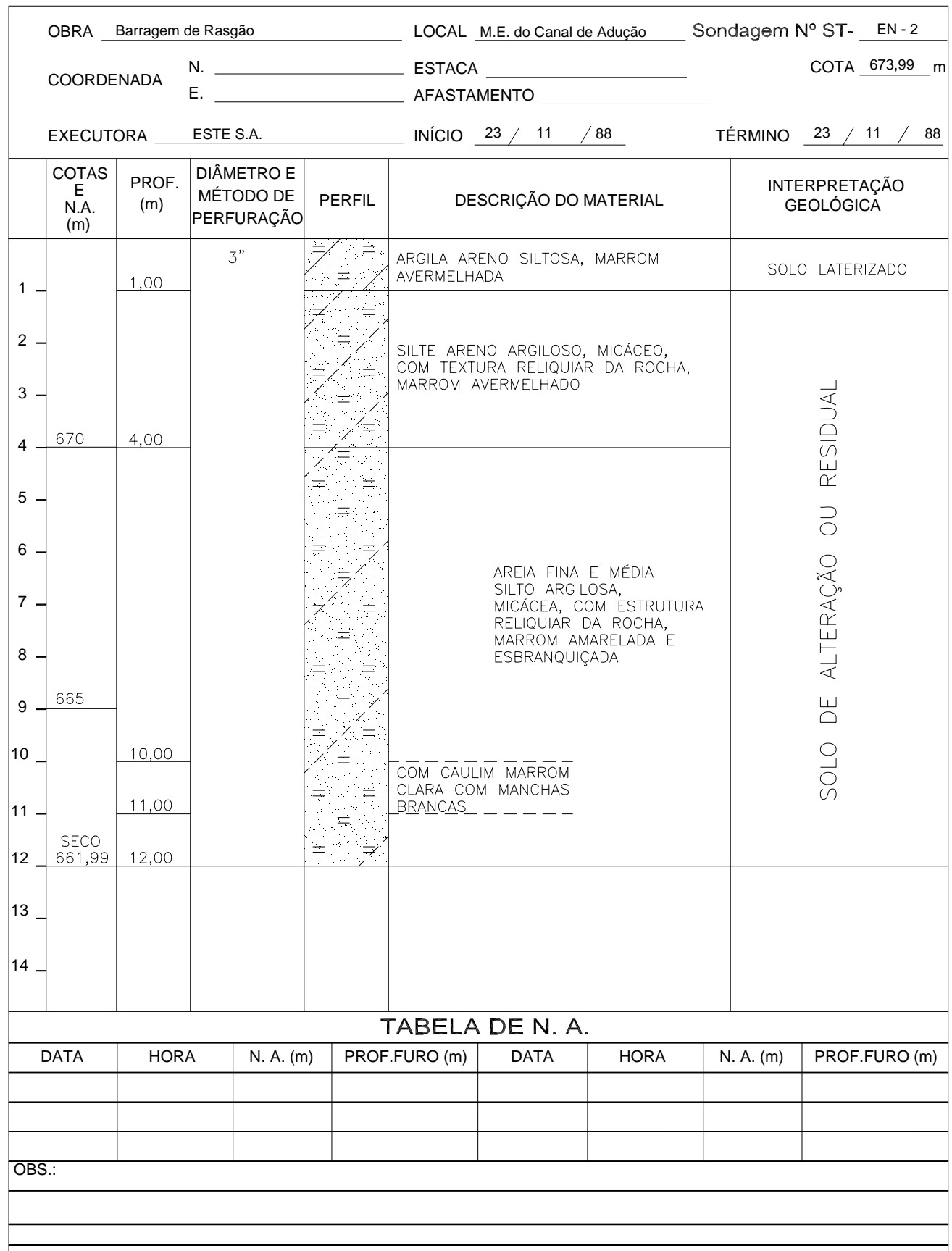

PERFIL INDIVIDUAL DA SONDAGEM A TRADO ST- $\quad$ EN - 2

\begin{tabular}{|l|l|l|l|l|l|l|l|}
\hline & & & & & HORIZ: $\quad-$ & No \\
VERT.: & 1:100 &
\end{tabular}

FIGURA 44 - Perfil individual de sondagem a trado. 


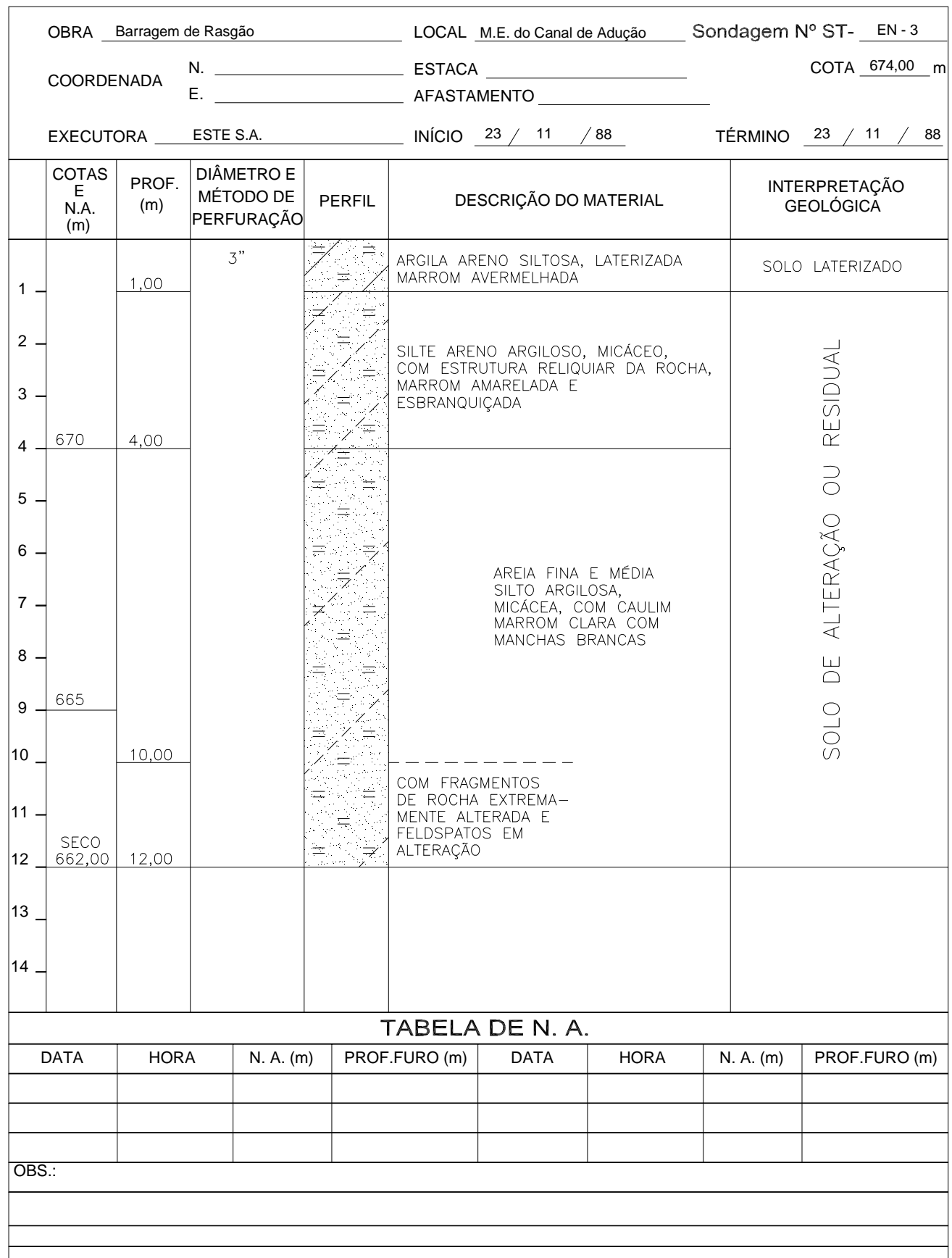

PERFIL INDIVIDUAL DA SONDAGEM A TRADO ST- $\quad$ EN - 3

\begin{tabular}{|l|l|l|l|l|l|l|l|}
\hline & & & & & HORIZ: $\quad-$ & No \\
VERT.: $\quad 1: 100$ &
\end{tabular}

FIGURA 45 - Perfil individual de sondagem a trado. 


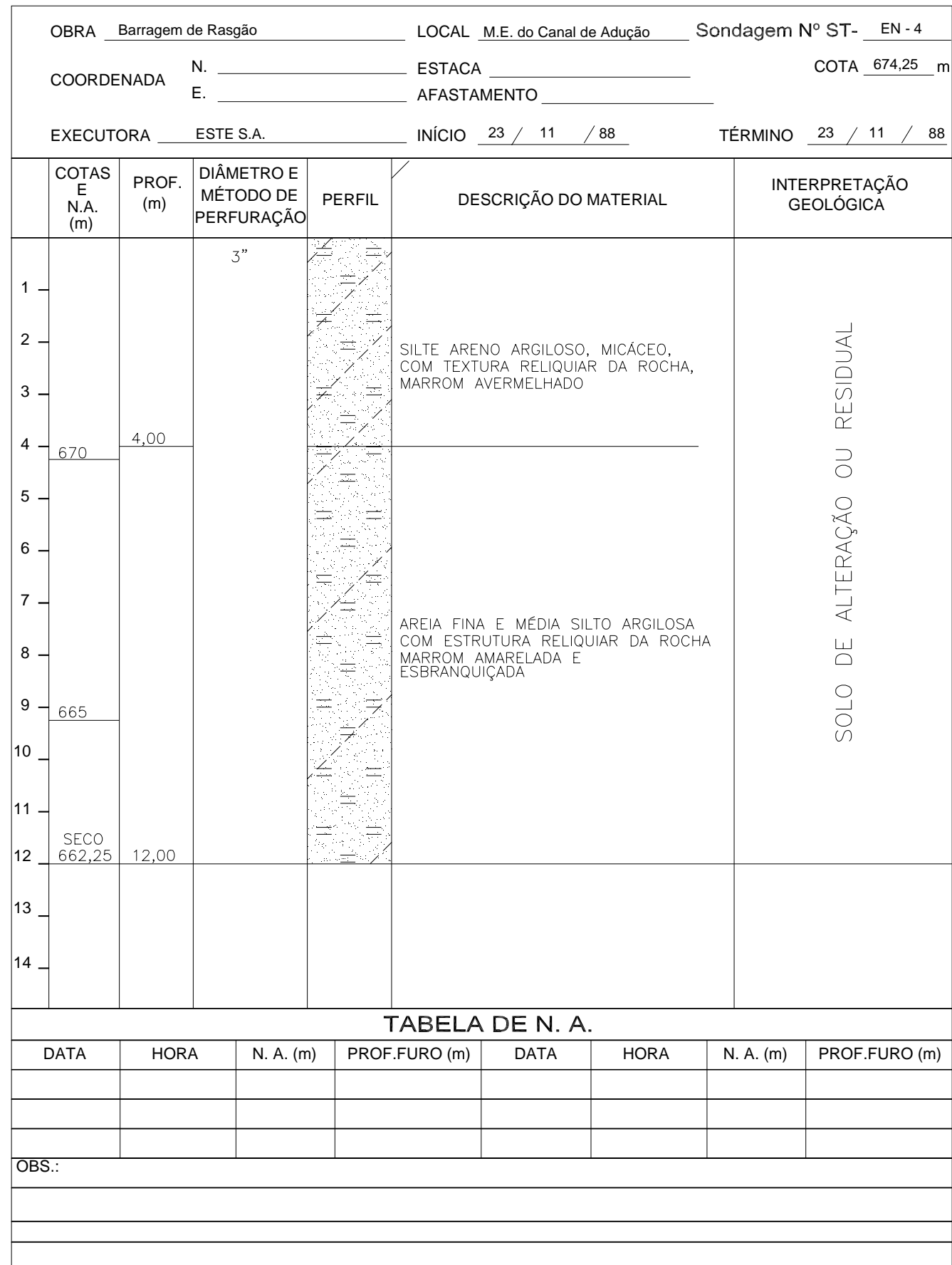

\section{PERFIL INDIVIDUAL DA SONDAGEM A TRADO ST- $\quad$ EN - 4}

\begin{tabular}{|l|l|l|l|l|l|l|l|}
\hline & & & & & HORIZ.: - & No \\
\cline { 1 - 5 } DESENHO & VERIFICADO & RESP.TÉCNICO & APROVADO & DATA & VERT.: $\quad 1: 100$ & \\
\hline
\end{tabular}

FIGURA 46 - Perfil individual de sondagem a trado. 


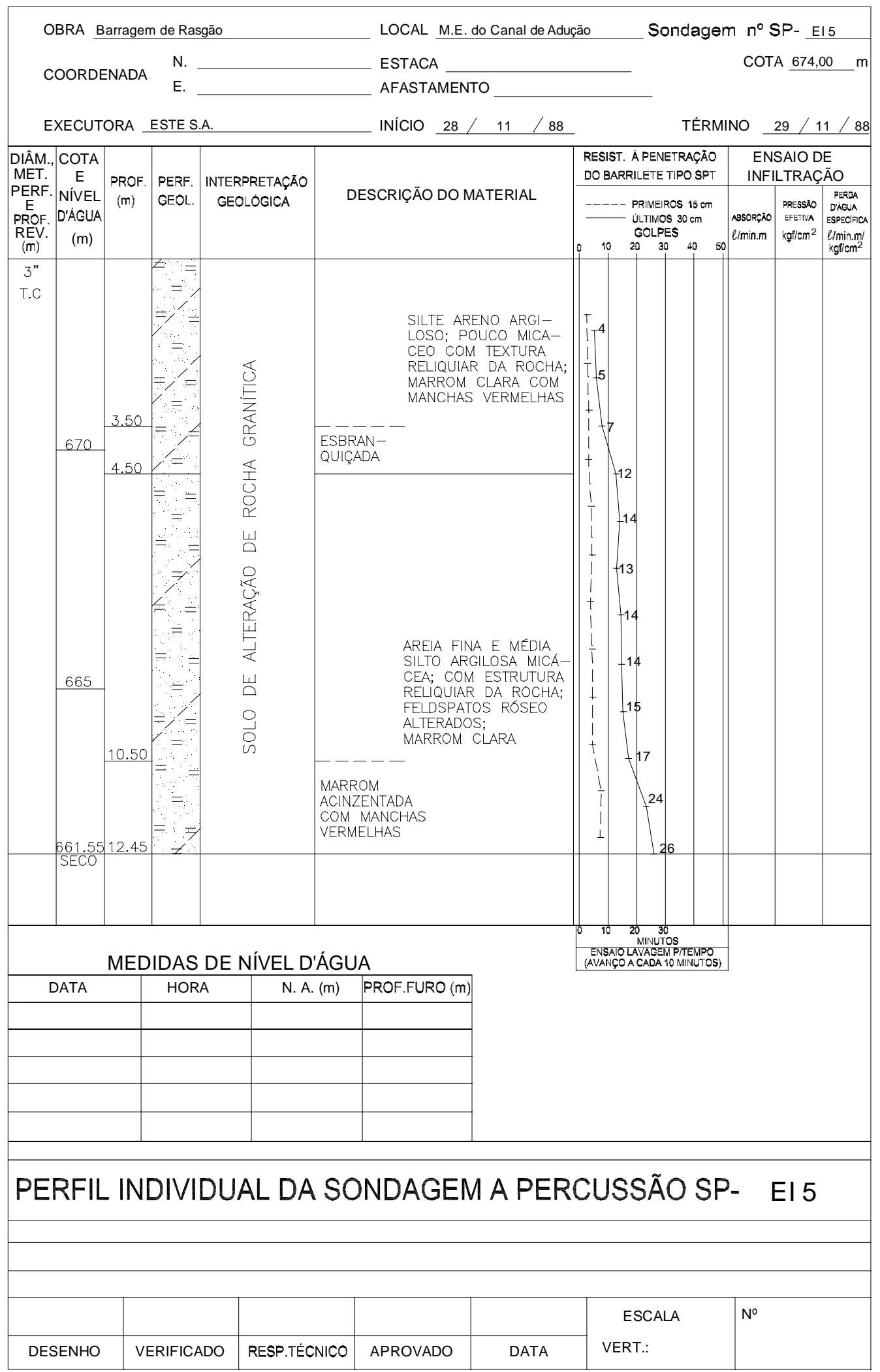

FIGURA 47 - Perfil individual de sondagem a percussão. 


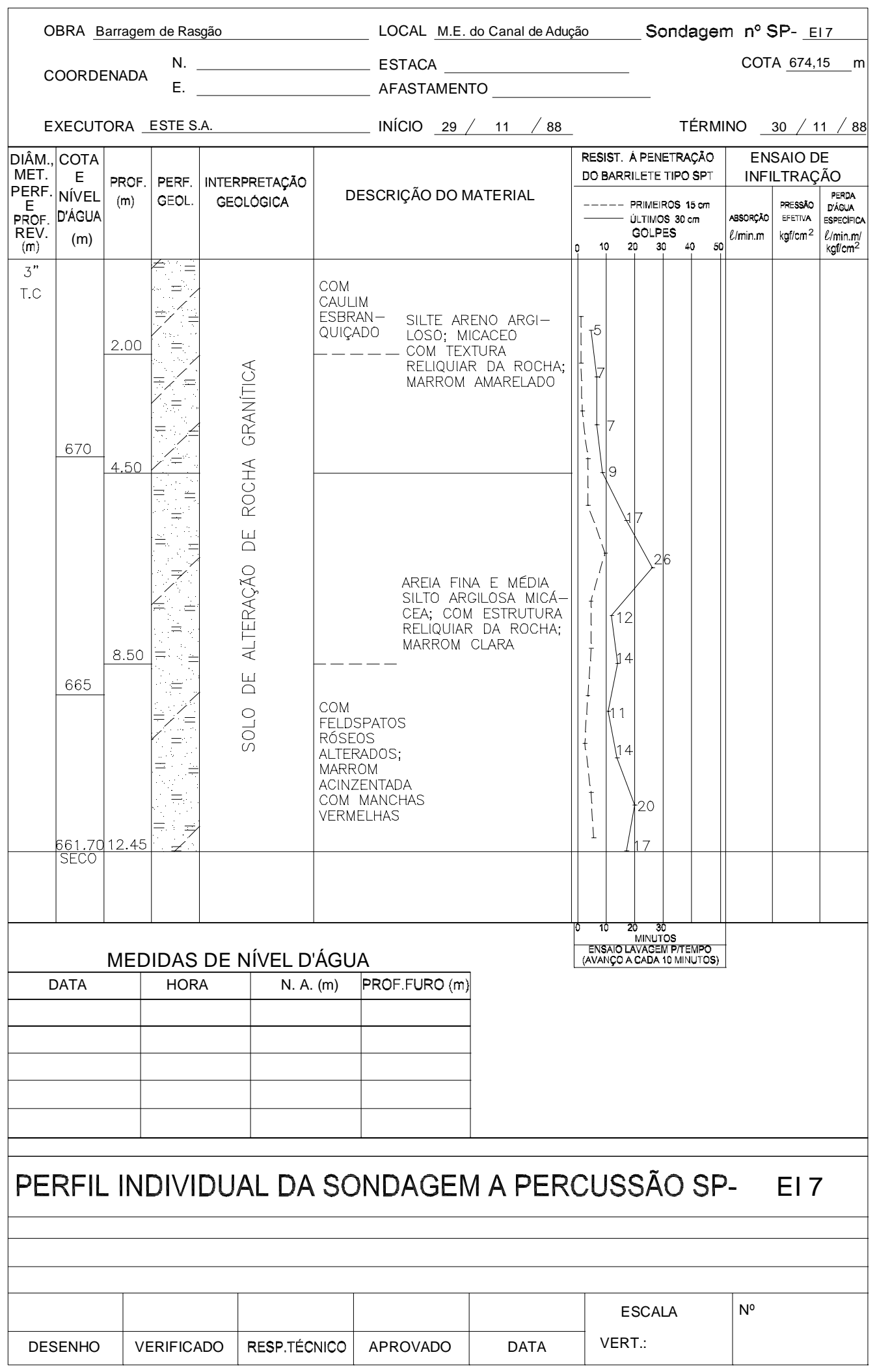

FIGURA 48 - Perfil individual de sondagem a percussão. 


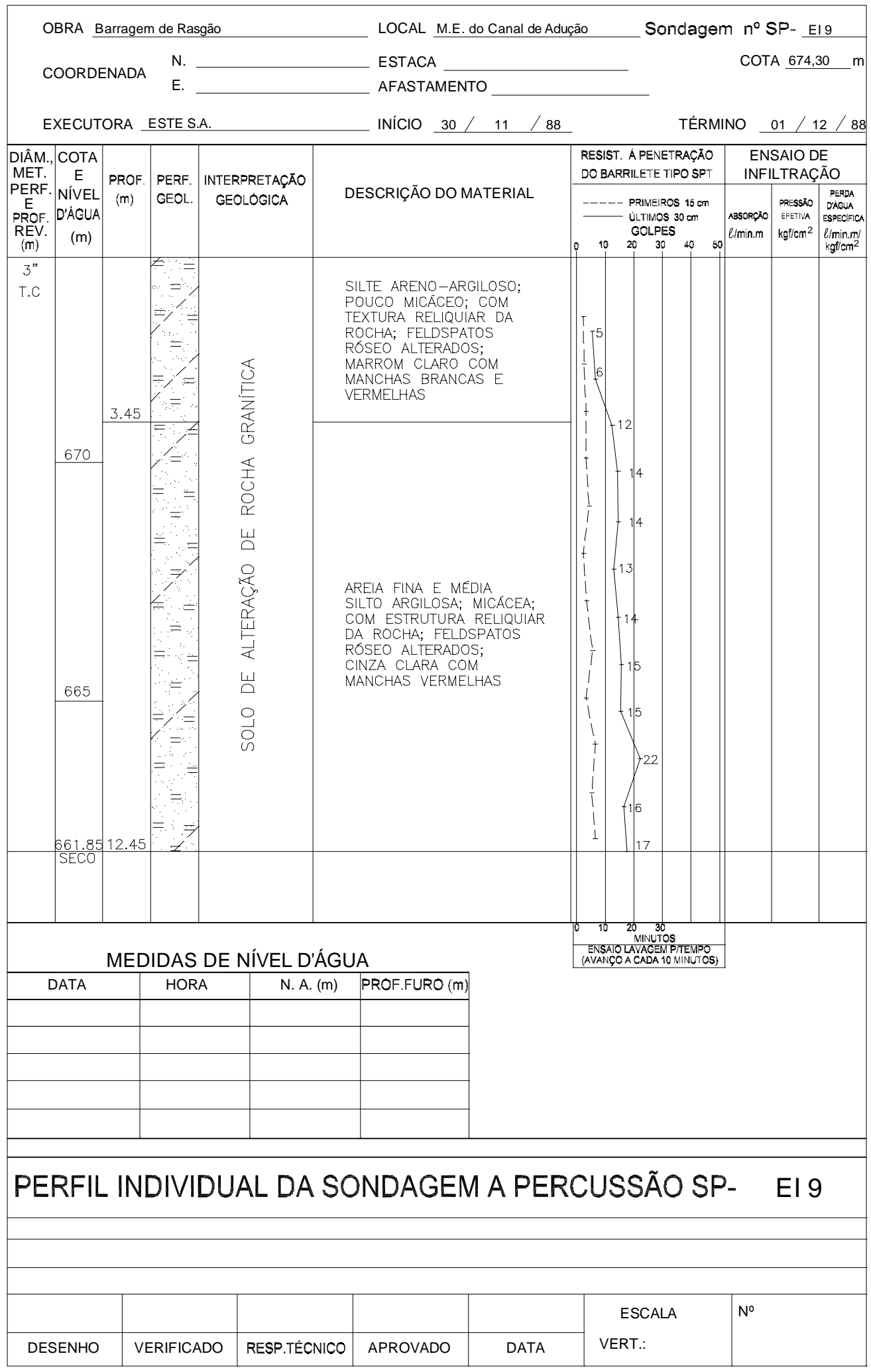

FIGURA 49 - Perfil individual de sondagem a percussão. 


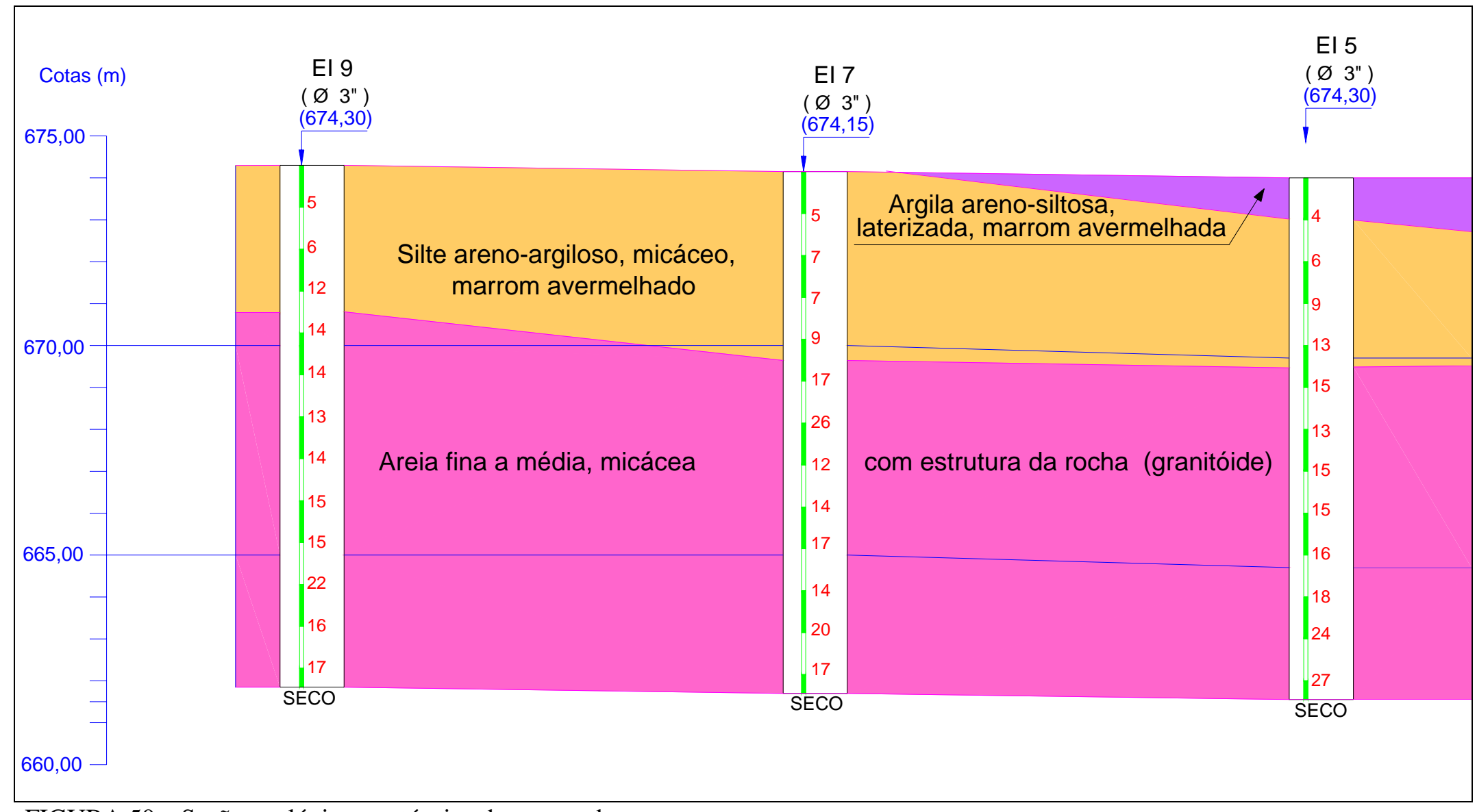

FIGURA 50 - Seção geológico-geotécnica do campo de prova. 


\subsubsection{Ensaios crosshole}

Ao final dos trabalhos de tratamento com injeção de solo-cimento, que ocorreram no segundo semestre de 1988, foi proposta a execução de um teste com o método geofísico como complemento ao levantamento com ensaios de infiltração para avaliar a eficiência deste tratamento adotado. Com se tratava de uma técnica ainda inédita para tal fim, foi elaborado um projeto desse levantamento geofísico, levando-se em consideração as informações obtidas dos ensaios preliminares realizados, das experiências adquiridas nos ensaios rotineiros com o método crosshole e do tratamento efetuado sob a estrutura de geração da Usina de Rasgão.

A decisão em realizar os testes junto ao canal de adução (FIGURA 34) deveu-se à semelhança das condições geológicas entre os maciços do campo de prova e aquele que recebeu tratamento com injeção de solo-cimento. Trata-se de uma área retangular de $6 \mathrm{~m}$ de comprimento e $4 \mathrm{~m}$ de largura, sendo que nos vértices foram localizados os furos, com profundidade de $12 \mathrm{~m}$, empregados para o levantamento dos ensaios geofísicos (FIGURA 42).

Para garantir as mesmas condições de execução dos ensaios, antes e depois do tratamento, ficou determinado que o emissor de ondas seria introduzido no furo EN 4 e os receptores nos demais furos, permitindo leituras em duas laterais e numa das diagonais do retângulo. Assim, foram realizadas medidas de tempo de propagação das ondas sísmicas entre os pares de furos:

- PAR 1: EN 4 e EN 1, distanciados de 4 m;

- PAR 2: EN 4 e EN 2, separados de 7,21 m;

- PAR 3: EN 4 e EN 3, espaçados de 6 m. 
Para isso, o posicionamento dos geofones e da fonte emissora foi observado com cuidado, devendo estar no mesmo horizonte de interesse, à mesma cota, uma vez que o objetivo foi captar a onda transmitida diretamente em uma dada camada do subsolo, evitando-se as ondas refratadas e/ou refletidas.

Os tempos de propagação das ondas secundárias (S) medidos entre os pares de furos, antes e depois do tratamento, estão sendo apresentados na TABELA 10. Em função do caminho de propagação dessas ondas, a partir do furo de emissão em direção aos três geofones, foram levantadas três hipóteses relativas aos tempos de propagação depois da injeção. Na primeira hipótese, foi admitida que a maior redução no tempo de propagação das ondas S ocorreria no PAR 2. Esta hipótese foi formulada devido ao maior percurso das ondas ao longo da cortina formada pelos furos injetados, que modificaram e enrijeceram o maciço terroso, tornando-o mais propício à propagação dessas ondas sísmicas. A maior velocidade de propagação pela linha injetada foi comprovada no ensaio realizado entre os furos EI 5 e EI 9 (TABELA 12).

A segunda hipótese levantada foi a possibilidade de ocorrer redução no tempo de propagação no PAR 1, porém relativamente menor que no PAR 2. Tal fato está baseado no menor comprimento da "linha injetada" ao longo do trajeto das ondas S.

A terceira hipótese aventada, na época, foi a inalteração do tempo de propagação das ondas S no PAR 3, mesmo depois da injeção. Em princípio, os resultados apresentados na TABELA 10 confirmam as hipóteses levantadas. Entretanto, as análises estatísticas efetuadas mostraram também que no PAR 3 ocorreu redução no tempo de propagação. No capítulo seguinte desta pesquisa, foram discutidos os motivos desta questão.

No levantamento geofísico efetuado no campo de prova, foi dada atenção especial aos ensaios para medir o tempo de propagação das ondas S. Esta atitude foi tomada em função da influência da saturação do meio na velocidade de propagação das ondas. As ondas S se propagam pela porção sólida do solo e não sofre alterações significativas pela 
variação da saturação do meio. Ao contrário, a velocidade de propagação das ondas $\mathrm{P}$ aumenta com a saturação do terreno. Ainda que exista essa influência, foi aproveitada a oportunidade para realizar medidas nos tempos de propagação das ondas P. Na TABELA 11 foram apresentados os tempos medidos das ondas primárias (P), nos mesmos pares de furos onde foram realizadas as medidas das ondas $\mathrm{S}$. Para as ondas $\mathrm{P}$, também foram admitidas reduções nos tempos de propagação, à semelhança das ondas S. Os resultados mostraram que as reduções nos tempos de propagação dessas ondas foram relativamente menores que os das ondas S.

Na TABELA 12, podem ser comparadas, nas profundidades de 1 e $2 \mathrm{~m}$, as velocidades de propagação das ondas S em terreno natural e depois da injeção, bem como ao longo da injetada (cortina de injeção). Nota-se que em todas as situações houve aumento na velocidade de propagação das ondas S. Pode-se observar ainda que as velocidades ao longo da linha injetada são bem maiores que as velocidades nos pares de furos ensaiados.

É importante mencionar que nos ensaios geofísicos foram utilizados dois tipos diferentes de fonte de onda. O primeiro, utilizado para medidas da propagação das ondas S, é um martelo com mecanismo de inversão de direção de impacto. Esse martelo foi fixado na parede do furo com auxílio de um dispositivo hidráulico. As ondas são emitidas por meio de impactos mecânicos. O segundo foi empregado para obter a propagação das ondas P. Tratase de um tipo de air gun, que também foi fixado na parede do furo com uso de um mecanismo pneumático. As ondas são emitidas rompendo-se, com ar comprimido, uma membrana de PVC.

Os registros dos tempos de propagação de cada tipo de onda emitida foram feitos a cada metro de profundidade, utilizando-se um sismógrafo da Bison, com registrador digital de fita magnética, disponível na época. Atualmente, tais ensaios podem ser realizados com equipamentos modernos que possuem registro digital em disquetes ou sistema de transferência direta das informações para microcomputadores. 
TABELA 10 - Tempo de propagação das ondas $\mathrm{S}$ entre pares de furos, no campo de prova da Usina de Rasgão.

\begin{tabular}{c|c|c|c|c|c|c}
\hline \multirow{2}{*}{ Profundidade (m) } & \multicolumn{2}{|c|}{ Tempo antes da injeção (ms) } & \multicolumn{3}{c}{ Tempo após a injeção (ms) } \\
\cline { 2 - 7 } & PAR 1 & PAR 2 & PAR 3 & PAR 1 & PAR 2 & PAR 3 \\
\hline 1 & 24,78 & 38,44 & 31,15 & 21,76 & 33,73 & 29,80 \\
\hline 2 & 22,06 & 39,43 & 25,07 & 19,47 & 29,57 & 24,38 \\
\hline 3 & 23,08 & 33,75 & 25,40 & 18,31 & 27,14 & 24,70 \\
\hline 4 & 18,88 & 34,14 & 24,80 & 17,23 & 24,48 & 23,30 \\
\hline 5 & 18,31 & 25,06 & 21,60 & 14,28 & 21,53 & 21,95 \\
\hline 6 & 16,52 & 23,01 & 21,24 & 15,63 & 20,39 & 19,17 \\
\hline 7 & 15,68 & 21,38 & 20,06 & 14,45 & 20,39 & 18,58 \\
\hline 8 & 13,89 & 20,35 & 18,58 & 12,39 & 18,91 & 18,29 \\
\hline 9 & 13,86 & 20,35 & 17,70 & 12,39 & 18,29 & 16,90 \\
\hline 10 & 13,10 & 19,20 & 19,12 & 12,04 & 17,11 & 17,11 \\
\hline
\end{tabular}

TABELA 11 - Tempo de propagação das ondas P entre pares de furos, no campo de prova da Usina de Rasgão.

\begin{tabular}{c|c|c|c|c|c|c}
\hline \multirow{2}{*}{ Profundidade (m) } & \multicolumn{2}{|c|}{ Tempo antes da injeção (ms) } & \multicolumn{2}{c}{ Tempo após a injeção (ms) } \\
\cline { 2 - 7 } & PAR 1 & PAR 2 & PAR 3 & PAR 1 & PAR 2 & PAR 3 \\
\hline 1 & 15,6 & 20,8 & 19,6 & 14,4 & 23,2 & 20,4 \\
\hline 2 & 13,2 & 21,2 & 16,8 & 13,2 & 20,4 & 17,2 \\
\hline 3 & 12,0 & 18,8 & 14,4 & 11,2 & 17,6 & 14,8 \\
\hline 4 & 12,0 & 16,8 & 14,0 & 9,6 & 11,6 & 14,0 \\
\hline 5 & 10,8 & 15,6 & 13,2 & 8,8 & 13,6 & 12,4 \\
\hline 6 & 9,2 & 14,0 & 12,0 & 8,8 & 14,0 & 12,4 \\
\hline 7 & 9,2 & 14,8 & 12,4 & 8,4 & 12,8 & 13,6 \\
\hline 8 & 9,4 & 14,0 & 13,2 & 7,2 & 11,6 & 12,8 \\
\hline 9 & 12,0 & 13,6 & 12,0 & 8,4 & 12,8 & 12,8 \\
\hline 10 & 10,0 & 13,2 & 11,6 & 7,2 & 12,4 & 12,4 \\
\hline
\end{tabular}


TABELA 12 - Comparação entre velocidades de propagação das ondas S, obtidas entre pares de furos e na cortina de injeção, no campo de prova da Usina de Rasgão.

\begin{tabular}{c|c|c|c|c|c|c|c}
\hline \multirow{2}{*}{$\begin{array}{c}\text { Profundidade } \\
(\mathbf{m})\end{array}$} & \multicolumn{5}{|c|}{ Velocidade no terreno (m/s) } & \multirow{2}{*}{$\begin{array}{c}\text { Velocidade ao longo da } \\
\text { linha injetada (cortina de } \\
\text { injeção) (m/s) }\end{array}$} \\
\cline { 2 - 7 } & Antes da injeção & \multicolumn{3}{c|}{ Após a injeção } & \\
\hline & PAR 1 & PAR 2 & PAR 3 & PAR 1 & PAR 2 & PAR 3 & \\
\hline 1 & 161 & 187 & 192 & 184 & 213 & 201 & 280 \\
\hline 2 & 181 & 191 & 239 & 205 & 243 & 245 & 339 \\
\hline
\end{tabular}

\subsubsection{Execução das injeções}

As injeções para o tratamento do maciço terroso foram realizadas nos furos situados na mediatriz maior do campo de prova (FIGURA 42). As atividades de montagem dos tubos de PVC, com válvulas-manchete a cada metro, instalação e confecção das bainhas obedeceram aos mesmos critérios dos trabalhos realizados para construção da cortina de vedação da tomada d’água da usina.

O início das injeções, de forma ascendente, ocorreu após 7 dias de cura das bainhas, tendo sido injetados $300 \ell$ de calda por válvula-manchete, exceto nas válvulas situadas nas proximidades da superfície. A FIGURA 51 mostra as quantidades de caldas injetadas em cada válvula. As válvulas com volumes inferiores a $300 \ell$ indicam que a calda extravasou na superfície, impedindo a continuação da injeção.

As caldas da bainha e de injeção foram confeccionadas de acordo com os traços utilizados no tratamento das fundações das estruturas da Usina de Rasgão, tendo sido adotados os seguintes procedimentos executivos:

1. ensaio sistemático de laboratório para medida e controle da umidade natural do solo da jazida;

2. preparação da lama (solo + água) em misturador de alta rotação e com circulação contínua da mistura; 


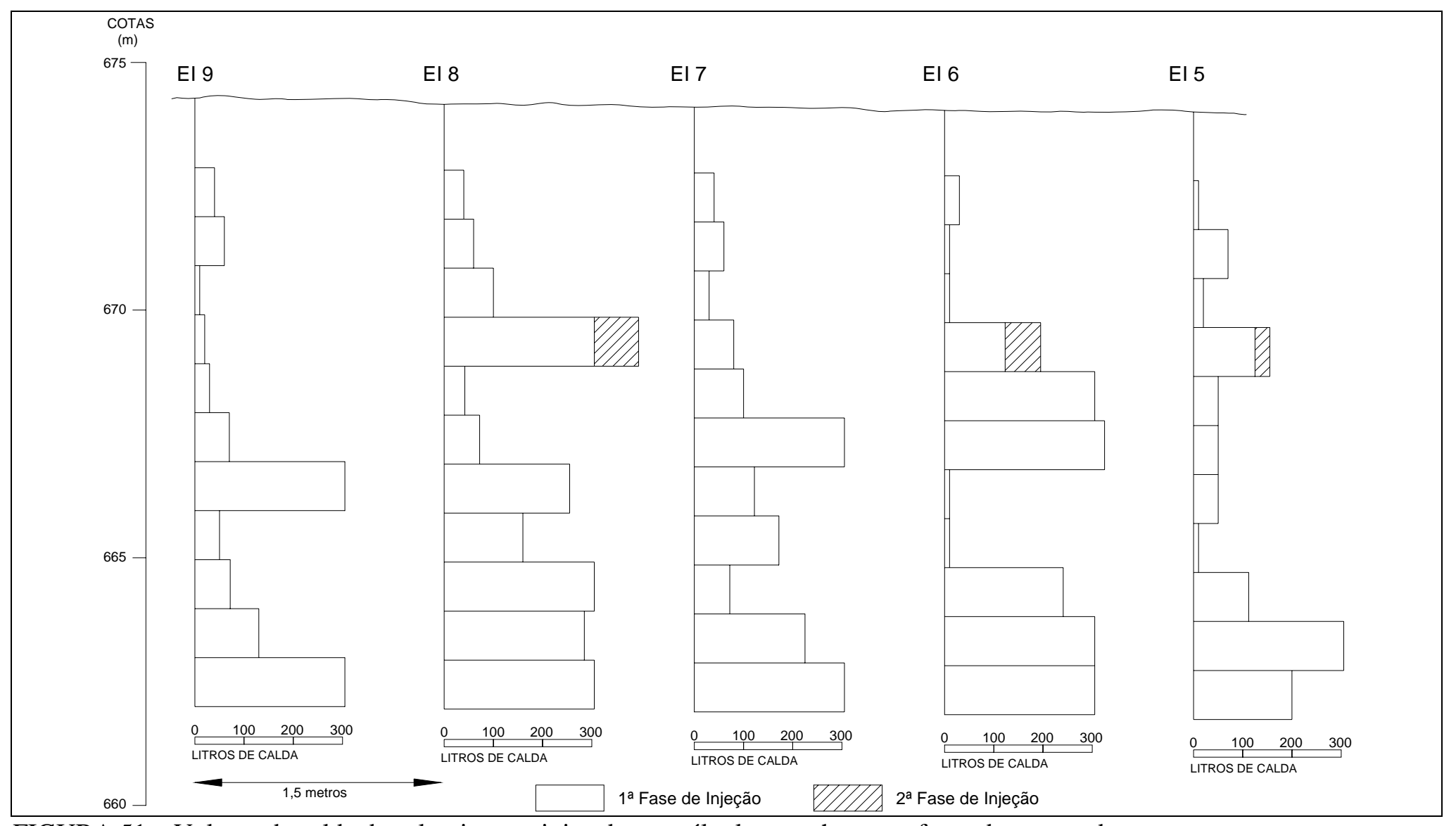

FIGURA 51 - Volume de calda de solo-cimento injetada por válvula-manchete nos furos do campo de prova. 
3. as proporções em massa de cimento:solo:água foram de 1:2:3 e 1:2:4, respectivamente, para as caldas das bainhas e injeções;

4. a calda foi batida durante 5 a 10 minutos e posteriormente transferida para 0 agitador, passando-se por uma peneira de $5 \mathrm{~mm}$.

Na TABELA 13, pode-se ver os resultados dos parâmetros reológicos das caldas utilizadas no teste efetuado no campo de prova. Esses valores correspondem às médias das determinações efetuadas sistematicamente nas caldas utilizadas no campo de prova. A umidade natural média do solo utilizado para a confecção das caldas foi de 20,2 \%, a massa específica média da lama de $1295 \mathrm{~kg} / \mathrm{m}^{3} \mathrm{e}$ da calda foi de $1430 \mathrm{~kg} / \mathrm{m}^{3}$, a sedimentação de 1,255\%, a fluidez de 7,45 s, a resistência à compressão simples de 0,5 e 0,76 MPa, respectivamente para 7 dias e 28 dias de idade. Nesta tabela, foram apresentados também os valores médios obtidos das caldas das bainhas.

A injeção da cortina foi iniciada no furo EI 5 em direção ao furo EI 9 e o tempo aguardado para a cura da bainha foi de 7 dias. As pressões de iniciação da ruptura da bainha e do maciço variaram entre 1,0 MPa e 7,0 MPa. A FIGURA 52 mostra a variação dessas pressões ao longo de cada um dos furos.

Com relação às pressões de injeção, estas variaram ao longo dos furos injetados, como mostram os gráficos da FIGURA 53. Pode-se observar nesses furos faixas de variações das pressões que foram atribuídas ao tipo de bomba empregado em toda campanha de injeção na Usina de Rasgão. Trata-se de uma bomba com pistões que possui alta potência e baixa velocidade de fluxo.

Ao comparar os gráficos da FIGURA 53, pode-se verificar certa uniformidade da pressão de injeção ao longo do furo EI 9. Maiores variações da pressão de injeção ao longo do furo foram observadas nas injeções do EI 5 e EI 6.

Encerrada a campanha de injeção, repetiram-se os ensaios geofísicos do tipo crosshole nos pares de furos anteriormente definidos (PAR 1, PAR 2 e PAR 3) após a cura 
adequada da caldas injetadas (30dias). Cabe ressaltar que foram empregados os mesmos critérios da primeira etapa.

TABELA 13 - Valores médios dos parâmetros das caldas utilizadas no campo de prova.

\begin{tabular}{|c|c|c|c|c|c|c|c|}
\hline $\begin{array}{c}\text { Traço } \\
\text { Cim:Solo:Água }\end{array}$ & $\begin{array}{c}\text { Umidade } \\
\text { natural } \\
(\%)\end{array}$ & $\begin{array}{c}\text { Massa } \\
\text { específica } \\
\text { da lama } \\
\left(\mathrm{kg} / \mathrm{m}^{3}\right)\end{array}$ & $\begin{array}{c}\text { Massa } \\
\text { específica } \\
\text { da calda } \\
\left(\mathrm{kg} / \mathrm{m}^{3}\right)\end{array}$ & $\begin{array}{l}\text { Sedimen- } \\
\text { tação (\%) }\end{array}$ & Fluidez (s) & $\begin{array}{c}\text { Rc aos } 7 \\
\text { dias (MPa) }\end{array}$ & $\begin{array}{c}\text { Rc aos } 28 \\
\text { dias (MPa) }\end{array}$ \\
\hline 1:2:3 (bainha) & 17,0 & 1300 & 1485 & 1,35 & 7,9 & 0,85 & 0,95 \\
\hline 1:2:4 (injeção) & 20,2 & 1295 & 1430 & 1,255 & 7,45 & 0,50 & 0,76 \\
\hline
\end{tabular}

Fluidez com cone de Marsh $\phi 10 \mathrm{~mm}$

Rc - resistência à compressão simples

O último trabalho executado no campo de prova, após o encerramento dos ensaios geofísicos, foi o levantamento das fraturas hidráulicas contendo caldas endurecidas, nas paredes de uma trincheira escavada ao longo dos furos EI 5 a EI 9. Esse levantamento permitiu observar a geometria e a distribuição das fraturas induzidas. A escavação da trincheira atingiu a profundidade de $2 \mathrm{~m}$, cujo limite foi estabelecido para evitar eventuais problemas de instabilidade na parede da trincheira.

Nas injeções efetuadas no campo de prova, foram utilizados corantes nas caldas de injeção para avaliar possíveis relações entre as fraturas hidráulicas, como mostra a FIGURA 54. Nesta figura, as fotos foram obtidas das caldas que extravasaram na superfície durante o processo de injeção. A montagem das fotos foi feita para permitir a comparação entre as diferentes cores e tonalidades utilizadas nas caldas. Registra-se que as cores utilizadas foram: vermelho, verde, marrom-escuro e marrom-claro. Os resultados desse levantamento foram apresentados no capítulo seguinte deste estudo. 


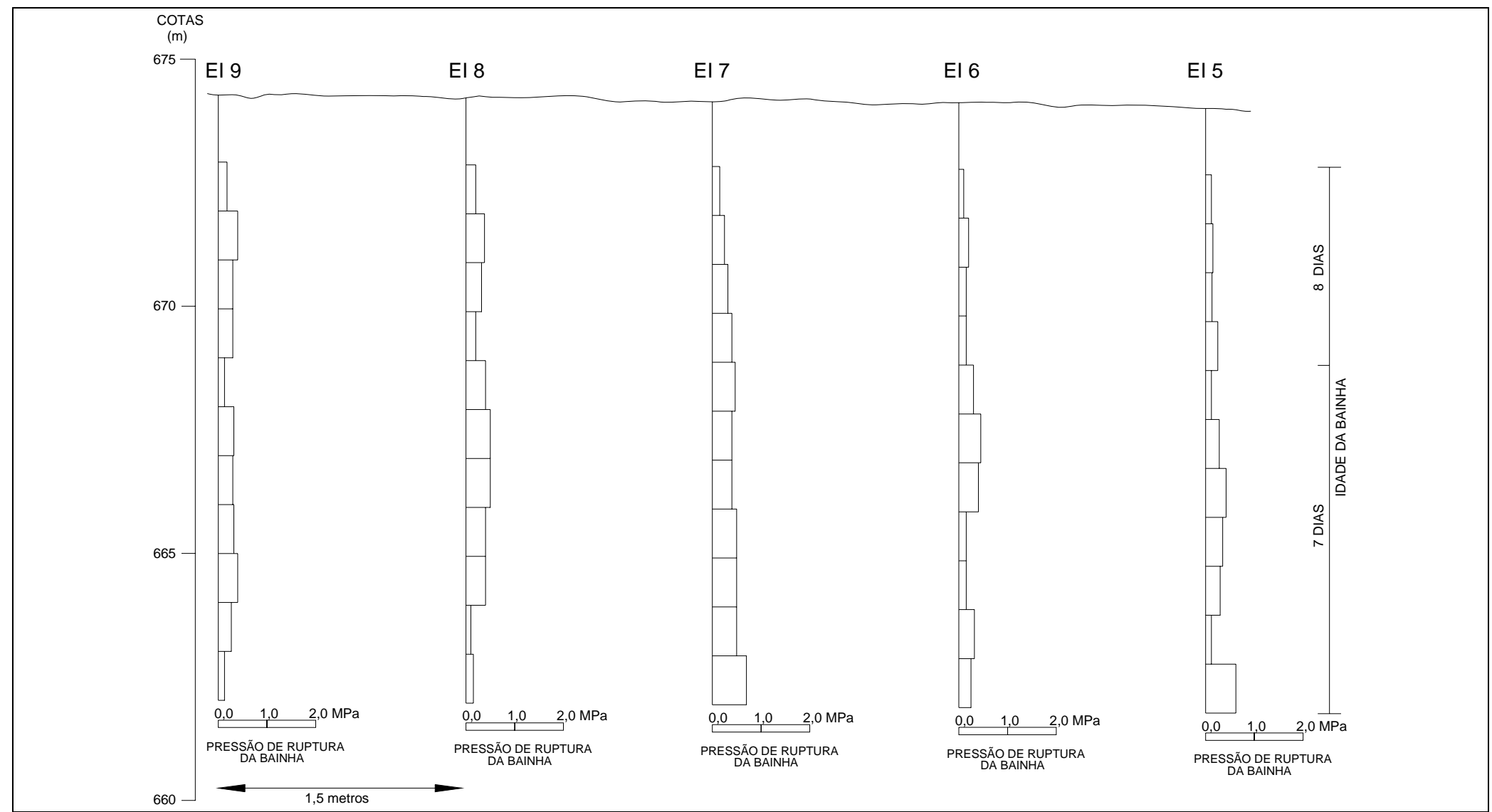

FIGURA 52 - Pressões de ruptura das válvulas-manchete ao longo dos furos. 


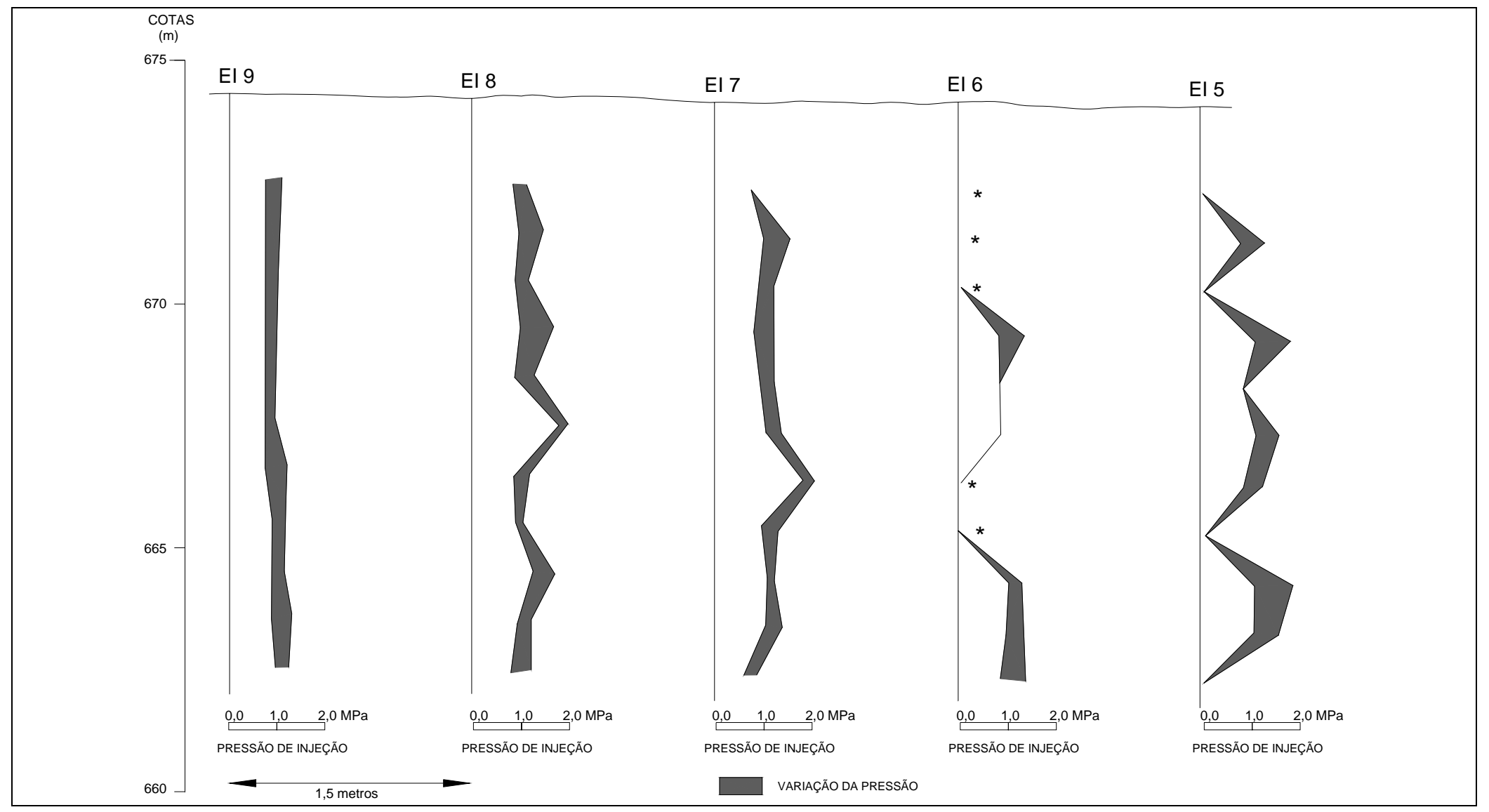

FIGURA 53 - Pressões de injeção ao longo dos furos. Nos locais assinalados $\left(^{*}\right)$ não foi medida a pressão devido ao extravasamento da calda na superfície. 


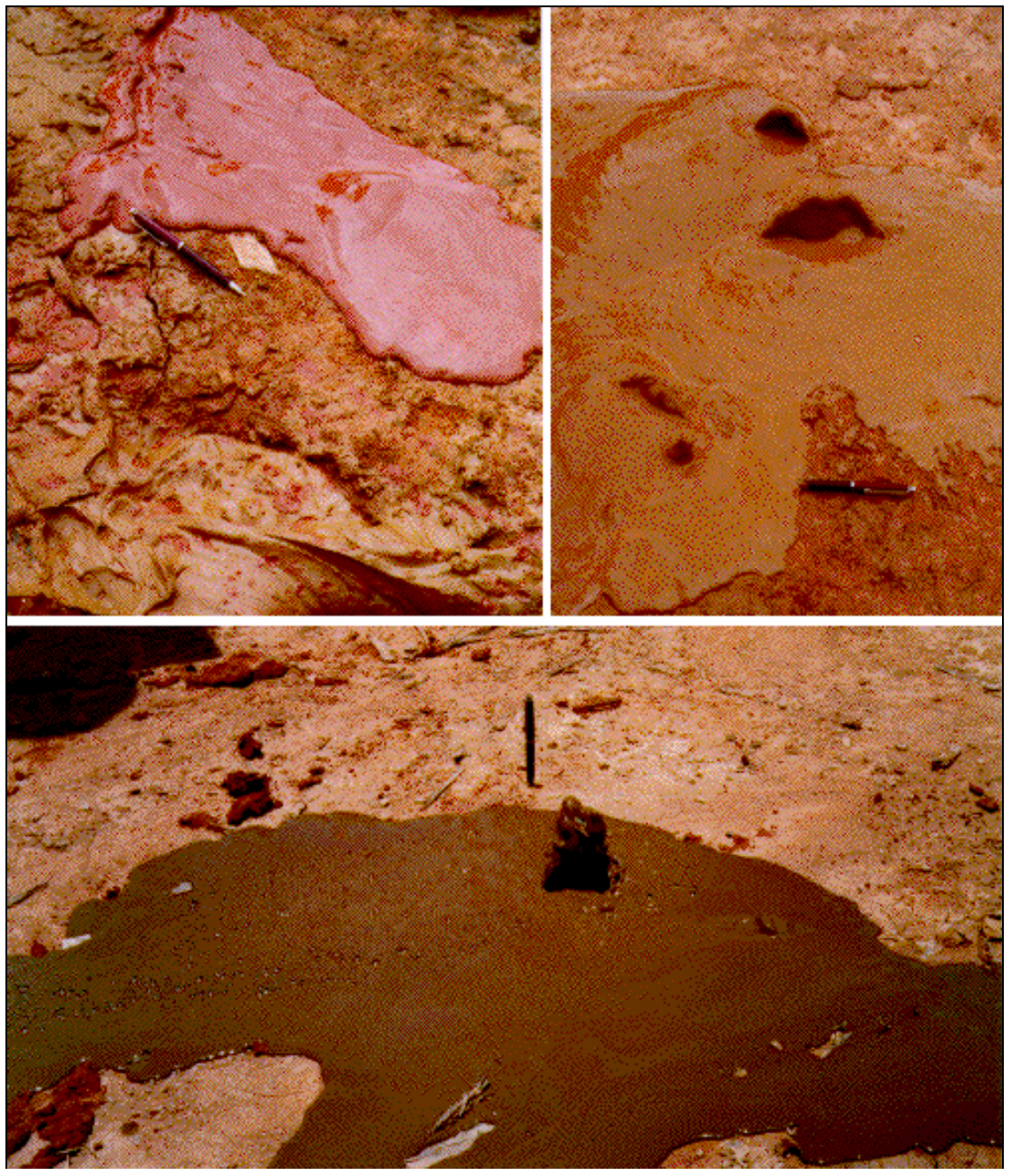

FIGURA 54 - Caldas de solo-cimento com corantes para avaliar forma, persistência, freqüência e relação entre fraturas hidráulicas. 


\section{ANÁLISE E DISCUSSÃO DOS RESULTADOS}

Neste capítulo, são apresentadas as análises realizadas e os resultados obtidos com os dados resultantes dos trabalhos executados na usina de Rasgão. Apresentam-se, ainda, comparações com os resultados extraídos das injeções efetuadas na Barragem de Balbina e na obra da Cooperativa de Laticínios, com o objetivo de obter respostas para as hipóteses preliminares efetuadas no início desta pesquisa. Para facilitar as análises, as informações técnicas foram reunidas em dois grupos distintos, de acordo com a finalidade da injeção, ou seja, redução da percolação de água pelo maciço (cortina de vedação) e consolidação.

Na cortina de vedação, foram realizadas análises das variações que ocorreram nas pressões, tanto da iniciação da ruptura do maciço como de injeção, com a finalidade de verificar possíveis acréscimos nos valores médios das pressões com a profundidade. Foram realizadas também as análises do comportamento das pressões nas diferentes ordens do tratamento (linhas primária, secundária e terciária).

Na cortina de vedação, foram efetuadas também as análises das alterações ocorridas nas pressões ao se realizar reinjeções em uma mesma válvula-manchete. Buscou-se nesta análise avaliar possíveis variações nas pressões após a alteração da condição natural do maciço, modificada com o tratamento preliminar da primeira fase de injeção.

Faz-se necessário lembrar que na campanha de injeção há distinção entre fase e ordem de tratamento. Fase de tratamento é a repetição da injeção que se promove no mesmo furo e na mesma válvula-manchete, após a cura do primeiro volume de calda injetada. Por outro lado, a ordem de tratamento refere-se à seqüência dos trabalhos de injeção, que se 
inicia pela linha denominada primária, passando-se sucessivamente para a secundária, terciária, etc.

Ainda na cortina de vedação, foram realizadas as análises do comportamento da pressão aplicada durante o processo de ruptura hidráulica do maciço e preenchimento da fratura induzida. Durante o fraturamento hidráulico, foi observado que a pressão aplicada variou, em ciclo, ao longo de todo o processo da ruptura e do preenchimento. O principal motivo que levou à realização dessa análise foi a busca de critério para paralisar a injeção nos tratamentos de maciços terrosos, com uso de válvulas-manchete.

No segundo grupo de dados, relativo às injeções de consolidação, as análises efetuadas não foram detalhadas como no caso da cortina de vedação. O principal motivo que impediu o aprofundamento das análises foi a concepção do projeto de consolidação. Para garantir a melhoria do maciço e a homogeneização por meio da introdução de caldas de solocimento, as perfurações foram distribuídas em malha geométrica sob a fundação do conjunto de geração da Usina de Rasgão. As injeções nesses furos foram realizadas aleatoriamente, obedecendo-se à distância mínima de 12 m entre furos sucessivos de injeção. A análise detalhada das pressões poderia ser realizada se o projeto exigisse que as injeções fossem executadas seqüencialmente, tomando-se por base o alinhamento dos furos.

Para realizar as análises do comportamento das pressões de iniciação da ruptura e de injeção, foram admitidas as seguintes condições e hipóteses:

- o diâmetro das perfurações, as válvulas-manchete, os equipamentos de injeção, entre outros itens relacionados ao processo do fraturamento, foram mantidos inalterados;

- o fraturamento hidráulico foi realizado em terreno situado acima do nível d’água;

- no momento da iniciação da ruptura do maciço, ou para sua propagação, aceitou-se que a calda de solo-cimento fosse do tipo incompressível. Nesta 
condição, foi admitida que a pressão medida no manômetro corresponde àquela necessária para a ruptura do conjunto válvula, bainha e maciço terroso;

- fundamentado nos estudos de QUADROS (1982); CRUZ (no prelo) e BARRADAS (1985), reconheceu-se que, durante o preenchimento da fratura induzida, a calda de solo-cimento é do tipo de Newton e o escoamento do fluxo ocorre em regime laminar;

- a pressão de injeção medida no manômetro inclui, além da pressão efetiva de injeção, as perdas de carga provocadas pela válvula-manchete, pelas fraturas da bainha e do maciço.

As análises das variações da propagação das ondas sísmicas medidas no campo de prova também foram destacadas neste capítulo.

Salienta-se que, em todas as análises das variações dos valores numéricos, recorreu-se aos recursos oferecidos pela estatística (COSTA NETO, 1977 e LANDIM, 1998). Os esclarecimentos desses recursos, os conceitos e os fundamentos básicos podem ser vistos no APÊNDICE deste trabalho. O uso da estatística, no presente estudo, não ficou restrito apenas à estatística descritiva, como determinações das médias, desvio padrão, etc. Foram utilizadas também outras técnicas disponíveis, como a análise de variância e o teste de Scheffé, respectivamente, para certificar e distinguir os resultados obtidos. Convém ressaltar que o objetivo do presente trabalho não foi discutir as técnicas da estatística, mas utilizá-las como ferramenta das análises que se fizeram necessárias, de acordo com o conceito e proposta formulados por LANDIM (1998). A disponibilidade dos métodos quantitativos em softwares, facilitaram a aplicação da estatística nas análises das variações das pressões de injeção e dos tempos de propagação das ondas sísmicas.

\subsection{Cortina de vedação}


No tratamento efetuado na cortina de impermeabilização ou de vedação da usina de Rasgão, as injeções seguiram uma seqüência cronológica de trabalho. A primeira linha injetada foi a de jusante (Linha Primária), seguida da linha de montante (Linha Secundária) e, finalmente, a linha central (Linha Terciária). A FIGURA 39 mostra a posição relativa entre as linhas.

Nestas linhas, foram realizados 77 furos, nos quais instalaram-se 1.293 válvulas do tipo manchete. A Linha Primária compreende 28 furos (identificados pelos números 300 a 327) e 500 válvulas, sendo que 46 delas apresentaram problemas durante o processo de abertura. A Linha Secundária, com 29 furos (identificados pelos números 328 a 356) e 462 válvulas, que também apresentaram problemas na abertura de 36 delas que não puderam sofrer injeção. Na Linha Terciária, foram realizados 20 furos, identificados pelos números 357 a 376, nos quais instalaram-se 312 válvulas, sendo que 14 não sofreram injeção.

A profundidade dos 77 furos da cortina de vedação variou entre 12 e 37 m, de acordo com os critérios estabelecidos no projeto. Os furos laterais da cortina ultrapassaram a camada superior do solo residual, enquanto que os furos da parte central atingiram o topo rochoso, como pode ser visto na FIGURA 36.

Das 1.293 válvulas instaladas, cujos registros técnicos são apresentados no ANEXO A, 96 delas apresentaram problemas no momento da abertura. Portanto, as análises estatísticas estão fundamentadas nos registros obtidos em 1.197 válvulas-manchete que totalizam 2.356 valores, sendo metade relativa à pressão de iniciação da ruptura da bainha e maciço e a outra metade à de injeção.

Levantamentos efetuados nos boletins de campo mostraram que foram dois os motivos que impediram a abertura das válvulas: a ocorrência do concreto de fundação da estrutura da tomada d’água e os núcleos rígidos de rocha alterada e matacões. Neste levantamento, foi verificado que 17 válvulas-manchete (1,5\% do total das instaladas) não puderam ser injetadas, devido ao posicionamento no interior do concreto, logo acima do 
contato com o solo residual. Portanto, nestes casos, houve erro de montagem das válvulasmanchete no tubo de PVC. A necessidade de se instalar pelo menos uma válvula-manchete imediatamente abaixo deste referido contato, foi com a finalidade de efetuar a colagem ou preenchimento de possíveis vazios existentes entre o concreto e o solo. A impossibilidade na abertura das outras 79 válvulas (6\% do total) foi devido à maior resistência do terreno ou à ocorrência de matacões e/ou núcleos mais resistentes. O levantamento efetuado da distribuição e localização dessas válvulas na cortina de vedação mostrou que a maior freqüência desse problema ocorreu em profundidade e na camada inferior do solo residual (jovem), já nas proximidades do topo rochoso. A TABELA 14 mostra essa distribuição.

TABELA 14 - Freqüência da distribuição e localização das válvulas não rompidas.

\begin{tabular}{c|c|c|c}
\hline $\begin{array}{c}\text { Intervalos de } \\
\text { profundidades }\end{array}$ & $\begin{array}{c}\text { Total de válvulas no } \\
\text { trecho }\end{array}$ & $\begin{array}{c}\text { Válvulas não } \\
\text { rompidas no trecho }\end{array}$ & Freqüência (\%) \\
\hline $655-650$ & 195 & 6 & 3 \\
\hline $650-645$ & 302 & 6 & 2 \\
\hline $645-640$ & 286 & 13 & 5 \\
\hline $640-635$ & 263 & 13 & 5 \\
\hline $635-630$ & 183 & 18 & 36 \\
\hline $630-625$ & 25 & 9 & 20 \\
\hline $625-620$ & 20 & 4 & 35 \\
\hline $620-615$ & 17 & 6 & 100 \\
\hline $615-610$ & 4 & 4 & \\
\hline
\end{tabular}

As 12 válvulas situadas nos dois primeiros intervalos de profundidade, portanto acima da cota 645 m, provavelmente não romperam devido à localização da válvulamanchete junto ao concreto de fundação da tomada d’água ou à existência de raros matacões alterados, como mostra a imagem da FIGURA 55, obtida na parede do poço E2.

Na listagem de dados da cortina de vedação (ANEXO A), as 96 válvulas que apresentaram problemas receberam o código 999, em função do programa de computador utilizado na análise estatística não reconhecer vazios no banco de dados. Esse mesmo código foi utilizado em outras 29 posições da listagem, totalizando 125 registros, que correspondem aos trechos onde não foram instaladas as válvulas-manchete devido aos critérios 
estabelecidos no projeto. Parte desses registros correspondem aos primeiros $5 \mathrm{~m}$ dos furos localizados nas ombreiras da tomada d'água da usina, onde não foram instaladas as válvulasmanchete pela ineficiência das injeções na região próxima da superfície. Este fato foi verificado durante a execução do tratamento da Barragem de Balbina. A outra parte dos 125 registros é relativa às ocorrências de concreto de fundação da usina, que não identificado durante as investigações para elaboração do projeto.

Na cortina de vedação, o volume total de calda injetada foi de $391 \mathrm{~m}^{3}$, obtido por meio da mistura de aproximadamente 79,5 t de cimento e 196 t de solo. É importante lembrar que, durante o tratamento, não houve mudanças nos traços das caldas da bainha e de injeção. Tal fato permitiu que fossem realizadas análises das variações das pressões, desconsiderando-se as possíveis interferências, devido às diferentes resistências nas caldas endurecidas.

\subsubsection{Análise das pressões de ruptura e de injeção por fases de tratamento}

As pressões de iniciação da ruptura do maciço $\left(\mathrm{P}_{\mathrm{r}}\right)$ e de injeção $\left(\mathrm{P}_{\mathrm{i}}\right)$, das diferentes fases de injeção, aplicadas na mesma-manchete apresentaram variações durante o processo de injeção, como mostram os dados obtidos durante esse processo, contidos na TABELA 15, bem como os resultados dos cálculos estatísticos apresentados no ANEXO C. 


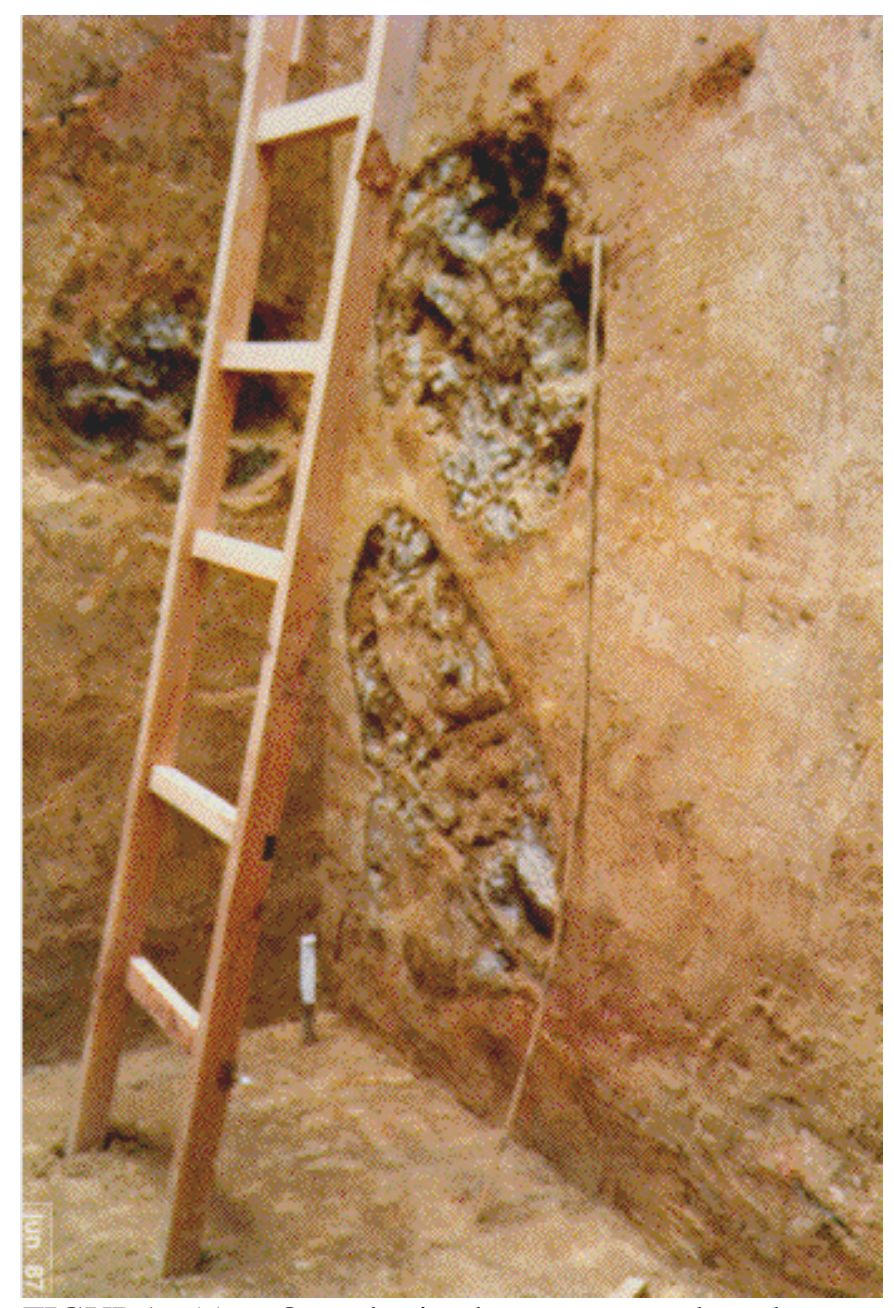

FIGURA 55 - Ocorrência de matacões alterados, ou núcleos de rocha alterada, nas paredes do poço E2. O piso do poço está na cota $646,25 \mathrm{~m}$, confirmando a existência de matacões acima da cota $645 \mathrm{~m}$.

Na análise visual dos valores apresentados na TABELA 15, pode-se verificar reduções em parte dos valores das pressões da segunda fase do tratamento em relação aos da primeira fase. Essas reduções podem estar associadas às possíveis falhas que ficaram na bainha após a injeção da calda da primeira fase, como mostra a FIGURA 67. Pode ser atribuída também à menor resistência mecânica da calda de injeção que preenche a fratura da bainha, provocada na injeção anterior. 
TABELA 15 - Valores das pressões de ruptura (Pr) e de injeção (Pi) das duas fases de injeção.

\begin{tabular}{|c|c|c|c|c|c|c|c|c|c|c|c|c|c|}
\hline \multirow{2}{*}{ Furo } & \multicolumn{2}{|c|}{ Profundidade (m) } & \multicolumn{2}{|c|}{ Pressões na $1^{\circ}$ Fase } & \multicolumn{2}{|c|}{ Pressões na $2^{\circ}$ Fase } & \multirow{2}{*}{ Furo } & \multicolumn{2}{|c|}{ Profundidade (m) } & \multicolumn{2}{|c|}{ Pressões na $1^{\circ}$ Fase } & \multicolumn{2}{|c|}{ Pressões na $2^{\circ}$ Fase } \\
\hline & de & $\mathbf{a}$ & Pr (MPa) & Pi (MPa) & Pr (MPa) & Pi (MPa) & & de & $\mathbf{a}$ & Pr (MPa) & Pi (MPa) & Pr (MPa) & Pi (MPa) \\
\hline$E-300 A$ & 34,75 & 35 & 999 & 999 & 10,0 & 2,4 & I - 335 & 15,75 & 16,75 & 0,4 & 0,2 & 0,8 & 0,5 \\
\hline$E-300 A$ & 33,75 & 34,75 & 4,0 & 1,0 & 5,0 & 1,4 & I - 335 & 14,75 & 15,75 & 2,0 & 0,2 & 5,0 & 0,2 \\
\hline$E-300 A$ & 32,75 & 33,75 & 3,0 & 1,0 & 8,0 & 2,0 & I - 337 & 13,18 & 12,18 & 1,0 & 0,8 & 1,6 & 0,8 \\
\hline$E-300 A$ & 31,75 & 32,75 & 2,0 & 2,0 & 10,0 & 2,0 & I - 338 & 7,85 & 8,85 & 2,5 & 0,6 & 3,0 & 0,8 \\
\hline$E-300 A$ & 30,75 & 31,75 & 4,0 & 1,7 & 8,0 & 1,8 & I - 339 & 14,15 & 15,15 & 1,8 & 0,2 & 2,0 & 0,8 \\
\hline$E-300 A$ & 29,75 & 30,75 & 5,0 & 1,5 & 2,5 & 1,5 & I - 339 & 13,15 & 14,25 & 1,5 & 0,6 & 1,8 & 0,6 \\
\hline$E-302 A$ & 6,75 & 7,75 & 1,5 & 1,0 & 2,0 & 0,5 & I - 340 & 7,85 & 8,87 & 1,4 & 0,8 & 2,0 & 0,8 \\
\hline E - 303 & 2,27 & 3,27 & 2,0 & 1,0 & 2,0 & 1,5 & I - 341 & 8,05 & 9,05 & 3,0 & 0,2 & 4,0 & 1,2 \\
\hline I- 305 & 9,25 & 10,25 & 0,8 & 0,2 & 0,6 & 0,4 & $\mathrm{I}-341$ & 4,05 & 5,05 & 1,2 & 0,2 & 2,5 & 0,7 \\
\hline $\mathrm{I}-308$ & 14,75 & 15,75 & 2,5 & 1,6 & 0,6 & 0,5 & I - 344 & 11,95 & 12,95 & 1,2 & 0,2 & 3,0 & 1,0 \\
\hline $\mathrm{I}-310$ & 26,75 & 27,75 & 2,0 & 1,0 & 2,0 & 1,0 & $\mathrm{I}-345$ & 7,25 & 8,25 & 0,8 & 0,2 & 1,8 & 1,0 \\
\hline$I-312$ & 31,6 & 31,85 & 0,2 & 0,2 & 2,0 & 0,5 & $\mathrm{I}-346$ & 3,25 & 4,25 & 1,0 & 0,3 & 4,0 & 1,0 \\
\hline$I-312$ & 30,6 & 31,6 & 0,4 & 0,2 & 1,5 & 0,3 & I - 347 & 6,25 & 7,25 & 2,5 & 0,8 & 2,5 & 1,0 \\
\hline $\mathrm{I}-312$ & 29,6 & $\begin{array}{l}30,6 \\
\end{array}$ & 0,4 & 0,2 & 4,0 & 0,5 & I - 347 & 3,25 & 4,25 & 5,0 & 1,0 & 1,8 & 1,2 \\
\hline$I-313$ & 14,35 & 15,35 & 1,8 & 0,6 & 1,2 & 1,0 & $\mathrm{I}-350$ & 26,26 & 27,26 & 2,0 & 0,6 & 6,0 & 2,2 \\
\hline $\mathrm{I}-314$ & 14,25 & 15,25 & 0,8 & 0,8 & 2,0 & 0,4 & $\mathrm{I}-352$ & 17,26 & 18,26 & 1,0 & 0,2 & 1,0 & 0,4 \\
\hline I- 315 & 7,4 & 8,4 & 0,6 & 0,3 & 3,0 & 1,0 & I - 352 & 16,26 & \begin{tabular}{ll|}
17,26 \\
\end{tabular} & 1,5 & 0,2 & 1,0 & 0,4 \\
\hline $\mathrm{I}-315$ & 4,4 & 5,4 & 1,2 & 0,6 & 1,0 & 0,6 & C - 360 & 26,75 & 27 & 3,0 & 1,0 & 7,0 & 0,6 \\
\hline $\mathrm{I}-316$ & 16,45 & 17,45 & 0,6 & 0,5 & 2,0 & 2,0 & C - 360 & 25,75 & 26,75 & 1,5 & 0,1 & 5,0 & 0,7 \\
\hline I- 316 & 13,45 & 14,45 & 1,0 & 0,4 & 6,0 & 1,8 & C - 360 & 9,75 & $\begin{array}{ll}10,75 \\
\end{array}$ & 6,0 & 0,6 & 2,8 & 0,6 \\
\hline I - 316 & 12,45 & 13,45 & 1,0 & 0,6 & 4,0 & 1,6 & C - 361 & 5,75 & 6,75 & 1,0 & 0,2 & 7,0 & 0,2 \\
\hline $\mathrm{I}-316$ & 11,45 & 12,45 & 1,0 & 0,6 & 4,0 & 1,0 & C - 363 & 3,75 & 4,75 & 2,0 & 1,0 & 2,0 & 0,8 \\
\hline I- 316 & 10,45 & 11,45 & 1,0 & 0,6 & 6,0 & 0,9 & C- 363 & 2,75 & 3,75 & 0,7 & 0,5 & 4,0 & 1,2 \\
\hline I - 316 & 9,45 & 10,45 & 1,0 & 0,6 & 5,0 & 1,0 & C - 363 & 2,2 & 2,75 & 4,0 & 0,2 & 2,0 & 0,8 \\
\hline$I-316$ & 8,45 & 9,45 & 1,0 & 0,6 & 4,0 & 1,0 & C - 364 & 12,25 & 13,25 & 4,0 & 1,0 & 7,0 & 1,2 \\
\hline I- 316 & 7,45 & 8,45 & 1,0 & 0,6 & 4,0 & 0,8 & C - 364 & 11,25 & 12,25 & 0,2 & 0,2 & 2,0 & 0,4 \\
\hline I - 316 & 6,45 & $\begin{array}{l}7,45 \\
\end{array}$ & 1,0 & 0,6 & 1,5 & 0,6 & C - 364 & 10,25 & 11,25 & 3,0 & 1,0 & 3,0 & 1,0 \\
\hline $\mathrm{I}-316$ & 5,45 & 6,45 & 2,0 & 1,0 & 2,0 & 1,0 & C - 364 & 9,25 & 10,25 & 2,0 & 1,0 & 3,0 & 1,0 \\
\hline I - 317 & 3,35 & 4,35 & 1,4 & 0,8 & 2,0 & 0,4 & C - 364 & 8,25 & \begin{tabular}{|c|}
9,25 \\
\end{tabular} & 2,0 & 0,5 & 4,0 & 1,0 \\
\hline $\mathrm{I}-318$ & 15,55 & 14,55 & 1,0 & 0,4 & 4,0 & 1,8 & C - 364 & 7,25 & 8,25 & 2,0 & 1,0 & 3,0 & 0,7 \\
\hline I - 318 & 14,55 & 15,55 & 0,3 & 0,2 & 3,0 & 1,6 & $\begin{array}{l}\text { C - } 364 \\
\end{array}$ & 6,25 & 7,25 & 2,0 & 1,0 & 4,0 & 0,7 \\
\hline $\mathrm{I}-318$ & 13,55 & 14,55 & 1,0 & 0,4 & 4,0 & 1,2 & C - 364 & 3,25 & 4,25 & 0,6 & 0,5 & 2,0 & 0,7 \\
\hline I- 318 & 12,55 & 13,55 & 1,0 & 0,4 & 1,0 & 1,0 & C-364 & 2,25 & 3,25 & 2,0 & 0,6 & 3,0 & 0,6 \\
\hline I- 318 & 11,55 & 12,55 & 1,0 & 0,8 & 1,0 & 1,0 & C - 365 & 12,75 & 13,75 & 4,0 & 1,0 & 3,0 & 1,0 \\
\hline I-318 & 10,55 & 11,55 & 0,6 & 0,2 & 1,8 & 1,0 & C - 365 & 11,75 & 12,75 & 2,0 & 1,0 & 3,0 & 0,8 \\
\hline I - 318 & 9,55 & 10,55 & 0,2 & 0,2 & 2,0 & 1,0 & C - 365 & 10,75 & 11,75 & 2,0 & 1,0 & 1,0 & 0,7 \\
\hline I - 318 & 8,55 & $\begin{array}{l}9,55 \\
\end{array}$ & 0,1 & 0,1 & 2,0 & 1,0 & C-365 & 9,75 & 10,75 & 3,0 & 1,0 & 4,0 & 0,6 \\
\hline I-318 & 7,55 & 8,55 & 0,2 & 0,2 & 2,0 & 0,8 & C - 365 & 5,75 & 6,75 & 1,0 & 0,6 & 4,0 & 0,6 \\
\hline I - 318 & 6,55 & $\begin{array}{l}7,55 \\
\end{array}$ & 0,2 & 0,2 & 1,8 & 0,8 & C - 367 & 11,55 & 12,55 & 1,5 & 0,8 & 2,0 & 0,6 \\
\hline $\mathrm{I}-318$ & 5,55 & 6,55 & 0,2 & 0,2 & 2,0 & 0,7 & C - 367 & 6,55 & 7,55 & 2,0 & 0,8 & 2,0 & 0,6 \\
\hline $\mathrm{I}-318$ & 4,55 & 5,55 & 0,4 & 0,2 & 2,0 & 0,6 & C - 368 & 4,25 & 5,25 & 1,0 & 1,0 & 2,0 & 0,6 \\
\hline I - 318 & 3,55 & 4,55 & 1,8 & 0,6 & 1,0 & 0,6 & C - 368 & 3,25 & 4,25 & 1,0 & 0,2 & 1,5 & 0,2 \\
\hline $\mathrm{I}-320$ & 10,75 & 11,75 & 1,2 & 0,9 & 1,2 & 0,6 & $\begin{array}{l}\text { C - } 368 \\
\end{array}$ & 2,25 & 3,25 & 1,0 & 0,2 & 5,0 & 1,0 \\
\hline I- 325 & 16,7 & $\begin{array}{l}17,7 \\
\end{array}$ & 0,7 & 0,7 & 2,0 & 0,8 & C - 368 & 1,7 & 2,25 & 1,0 & 0,6 & 1,0 & 0,5 \\
\hline I - 325 & 14,7 & 15,7 & 0,2 & 0,2 & 1,8 & 0,8 & C - 369 & 16,75 & 17,75 & 3,0 & 1,2 & 7,0 & 1,5 \\
\hline $\mathrm{I}-325$ & 13,7 & 14,7 & 0,2 & 0,2 & 1,8 & 0,8 & C - 369 & 11,75 & 12,75 & 4,0 & 1,0 & 4,0 & 1,0 \\
\hline$I-325$ & 12,7 & 13,7 & 0,2 & 0,2 & 2,0 & 0,6 & C-369 & 10,75 & 11,75 & 1,0 & 0,2 & 5,0 & 0,8 \\
\hline $\mathrm{I}-325$ & 11,7 & 12,7 & 0,2 & 0,2 & 2,5 & 0,6 & C - 370 & 15,05 & 16,05 & 2,0 & 0,4 & 2,0 & 0,4 \\
\hline I - 325 & 10,7 & $\begin{array}{ll}11,7 \\
\end{array}$ & 0,4 & 0,2 & 1,0 & 0,4 & C - 370 & 14,05 & 15,05 & 1,0 & 0,2 & 3,0 & 0,6 \\
\hline $\mathrm{I}-325$ & 9,7 & 10,7 & 0,4 & 0,2 & 1,5 & 0,3 & C - 372 & 13,75 & 14,75 & 2,0 & 0,6 & 4,0 & 1,5 \\
\hline I - 325 & 8,7 & 9,7 & 1,5 & 0,2 & 0,5 & 0,2 & C - 372 & 11,75 & 12,75 & 4,0 & 0,8 & 1,5 & 1,0 \\
\hline $\mathrm{I}-333$ & 27,25 & 27,5 & 4,0 & 0,8 & 6,0 & 0,6 & C - 372 & 10,75 & 11,75 & 1,0 & 0,8 & 1,2 & 0,8 \\
\hline I - 333 & 26,25 & 27,25 & 8,0 & 0,8 & 4,0 & 0,6 & C - 373 & 16,75 & \begin{tabular}{ll|}
17,75 \\
\end{tabular} & 2,0 & 0,8 & 6,0 & 1,0 \\
\hline $\mathrm{I}-333$ & 25,25 & 26,25 & 4,0 & 0,8 & 1,8 & 0,8 & C - 373 & 7,75 & 8,75 & 2,0 & 0,6 & 2,6 & 0,7 \\
\hline I - 335 & 18,75 & 17,75 & 2,0 & 0,2 & 0,8 & 0,4 & V-376 & 10,75 & 11,75 & 0,6 & 0,5 & 1,0 & 0,4 \\
\hline I- 335 & 17,75 & 18,75 & 0,2 & 0,2 & 2,0 & 0,6 & & & & & & & \\
\hline
\end{tabular}

Na TABELA 16, pode-se notar que houve aumento na dispersão dos dados da pressão de iniciação da ruptura do maciço da segunda fase, indicado pela variância que passou de 1,88 para 3,46. Por outro lado, pode-se verificar que praticamente não houve dispersão da pressão de injeção na segunda fase, como mostra a variância que passou de 0,15 para 0,18 . Os resultados da estatística descritiva, apresentados nesta tabela, mostram nítido aumento na média dos valores das pressões na segunda fase de injeção. Os valores médios 
passaram de 1,7 MPa para 2,9 MPa e de 0,6 MPa para 0,8 MPa, respectivamente, para as pressões de ruptura e de injeção.

Evidências dessas elevações podem ser verificadas nos resultados contidos na TABELA 16, que são:

- soma dos valores das pressões que, na segunda fase de injeção, apresentaram aumentos da ordem de $76 \%$ e $45 \%$, respectivamente, nas pressões de ruptura e de injeção;

- elevação dos valores mínimos e máximos da primeira para a segunda fase, nos dois casos das pressões de ruptura e de injeção.

A comparação dos histogramas da distribuição das pressões de ruptura e de injeção, de acordo com os dados da TABELA 16, também evidencia que os valores médios das segunda fase superam, ligeiramente, os da primeira, como mostram as FIGURAS 56 e 57. Tal superioridade é mais nítida na pressão de iniciação da ruptura do maciço.

Além destas evidências, pode-se verificar também os aumentos das pressões da primeira para a segunda fase, determinando-se o coeficiente de variação (CV) das pressões que é o quociente entre o desvio padrão e a média. Ao calcular esse coeficiente, empregando-se os dados da TABELA 16 para as pressões de ruptura do maciço $\left(\mathbf{P}_{\mathbf{r}}\right)$ e de injeção $\left(\mathbf{P}_{\mathbf{i}}\right)$, tem-se que:

$$
\mathrm{CV}=\frac{\mathrm{S}}{\overline{\mathrm{X}}}
$$

onde:

$\mathbf{C V}=$ coeficiente de variação;

$\mathbf{S}=$ desvio padrão;

$\overline{\mathbf{X}}=$ média. 
Ao calcular os coeficientes nas duas fases, extraindo-se os valores do desvio padrão e das médias da TABELA 16, tem-se:

\section{a) Pressão de ruptura $\left(\mathbf{P}_{\mathbf{r}}\right)$}

- $\quad \mathbf{C V}_{\mathbf{1}}=81 \%$ (coeficiente de variação na primeira fase);

- $\mathbf{C V}_{2}=64 \%$ (coeficiente de variação na segunda fase).

b) Pressão de injeção $\left(\mathbf{P}_{\mathbf{i}}\right)$

- $\quad \mathbf{C V}_{\mathbf{1}}=63 \%$ (coeficiente de variação na primeira fase);

- $\quad \mathbf{C V}_{2}=47 \%$ (coeficiente de variação na segunda fase).

Nos dois casos, as reduções nos valores dos coeficientes indicam que os valores médios das pressões da segunda fase são maiores que os da primeira fase, confirmando as evidências já realçadas anteriormente.

TABELA 16 - Resultados dos cálculos estatísticos das pressões nas duas fases de injeção.

\begin{tabular}{|c|c|c|c|c|}
\hline \multirow{3}{*}{ Estatísticas } & \multicolumn{4}{|c|}{ Pressão (MPa) } \\
\hline & \multicolumn{2}{|c|}{ Ruptura (Pr) } & \multicolumn{2}{|c|}{ Injeção (Pi) } \\
\hline & $1^{\text {a }}$ Fase & $2^{a}$ Fase & $1^{a}$ Fase & $2^{a}$ Fase \\
\hline Média & 1,70 & 2,90 & 0,60 & 0,90 \\
\hline Erro padrão & 0,13 & 0,17 & 0,04 & 0,04 \\
\hline Mediana & 1,2 & 2,0 & 0,6 & 0,8 \\
\hline Moda & 1,0 & 2,0 & 0,2 & 1,0 \\
\hline Desvio padrão & 1,37 & 1,86 & 0,38 & 0,42 \\
\hline Variância da amostra & 1,88 & 3,46 & 0,15 & 0,18 \\
\hline Curtose & 4,04 & 1,63 & 1,00 & 1,21 \\
\hline Assimetria & 1,71 & 1,31 & 0,90 & 1,11 \\
\hline Intervalo & 7,9 & 9,5 & 1,9 & 2,0 \\
\hline Mínimo & 0,1 & 0,5 & 0,1 & 0,2 \\
\hline Máximo & 8,0 & 10,0 & 2,0 & 2,2 \\
\hline Soma & 183,1 & 322,8 & 64,7 & 93,9 \\
\hline Contagem & 110 & 110 & 110 & 110 \\
\hline Nível de confiança $(95,0 \%)$ & 0,26 & 0,35 & 0,07 & 0,08 \\
\hline
\end{tabular}



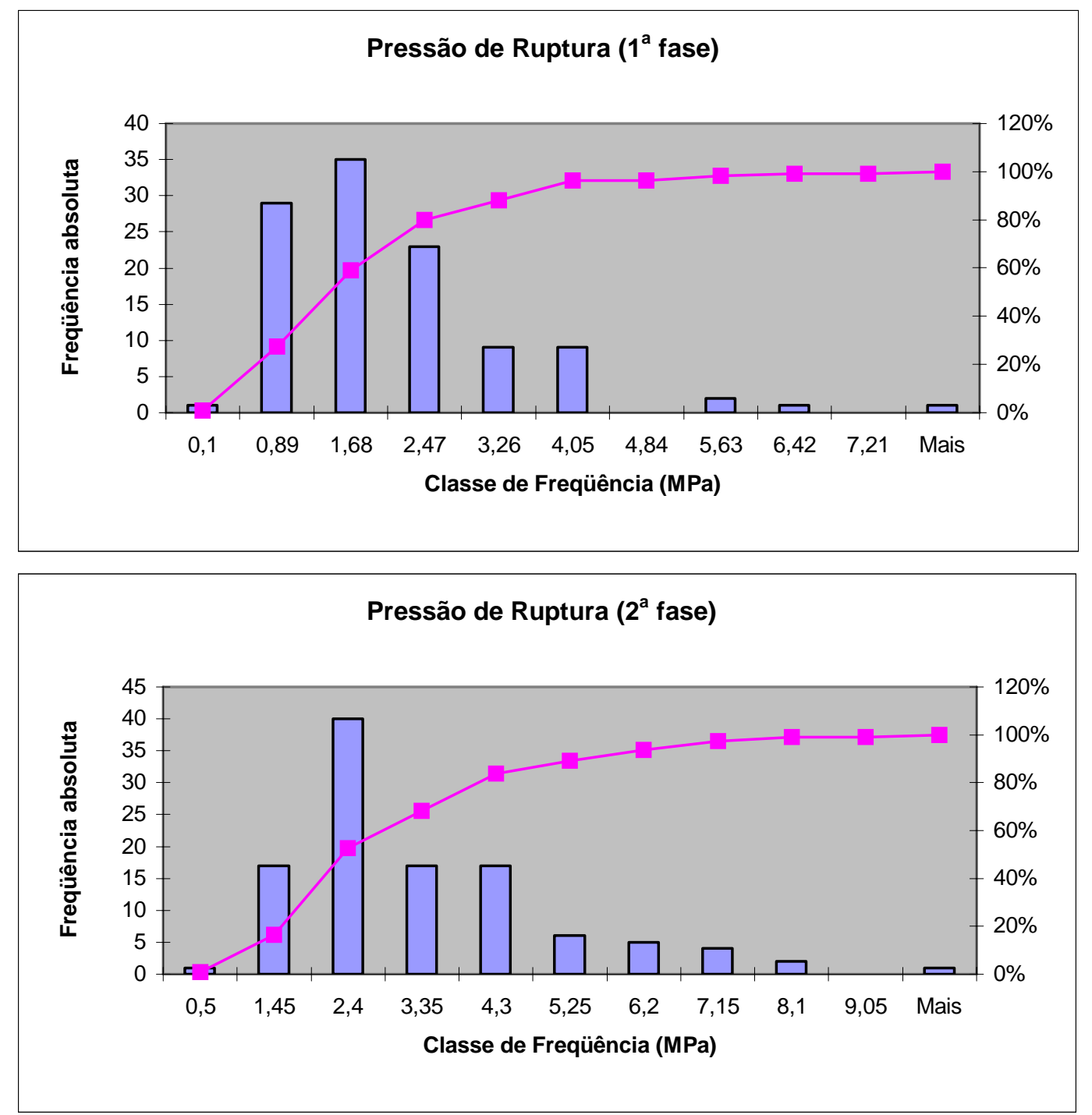

FIGURA 56 - Histogramas da pressão de iniciação da ruptura do maciço (Pr) nas duas fases de injeção.

Os resultados da análise estatística que indicaram ocorrências de acréscimos nas pressões da segunda fase, tanto da iniciação da ruptura como de injeção, foram submetidos ao teste-t de duas amostras em par para as médias (ver APÊNDICE). Para aplicar esse teste estatístico, admitiu-se, como hipótese $\left(\mathrm{H}_{0}\right)$, que as médias são iguais nas duas fases de injeção e, portanto, como hipótese alternativa $\left(\mathrm{H}_{1}\right)$ que há diferença entre as médias. Para o caso unicaudal, uma das médias é superior ou inferior à outra, conforme descrição a seguir. Os produtos obtidos dos cálculos são apresentados na TABELA 17. 
1. No teste unicaudal:

- hipótese admitida $\left(\mathrm{H}_{0}\right)$ : as pressões médias da primeira e segunda fases são iguais $\left(\overline{\mathrm{x}}_{1}=\overline{\mathrm{x}}_{2}\right)$;

- hipótese alternativa $\left(\mathrm{H}_{1}\right)$ : a média da pressão da primeira fase é maior ou menor que a da segunda fase $\left(\overline{\mathrm{x}}_{1}>\overline{\mathrm{x}}_{2}\right.$ ou $\left.\overline{\mathrm{x}}_{1}<\overline{\mathrm{x}}_{2}\right)$.

onde:

$\overline{\mathrm{X}}_{1}=$ média da pressão na primeira fase de injeção;

$\overline{\mathrm{x}}_{2}=$ média da pressão na segunda fase de injeção.

Os valores contidos na TABELA 17 foram os resultados calculados por meio da estatística. Cabe salientar que esses valores foram obtidos ao comparar as médias da primeira fase com as da segunda, e o sinal negativo da estatística t, indica essa condição. Para aceitar ou rejeitar a hipótese $\mathrm{H}_{0}$ faz-se necessária a comparação dos valores da estatística t (Stat t) e do $\mathbf{t}$ crítico unicaudal, de acordo com os critérios da estatística (ver APÊNDICE). E assim, tem-se que:

- $\quad$ Stat $\mathbf{t}=-6,768$;

- $\quad \mathbf{t}$ crítico $=-1,289$ (unicaudal). 

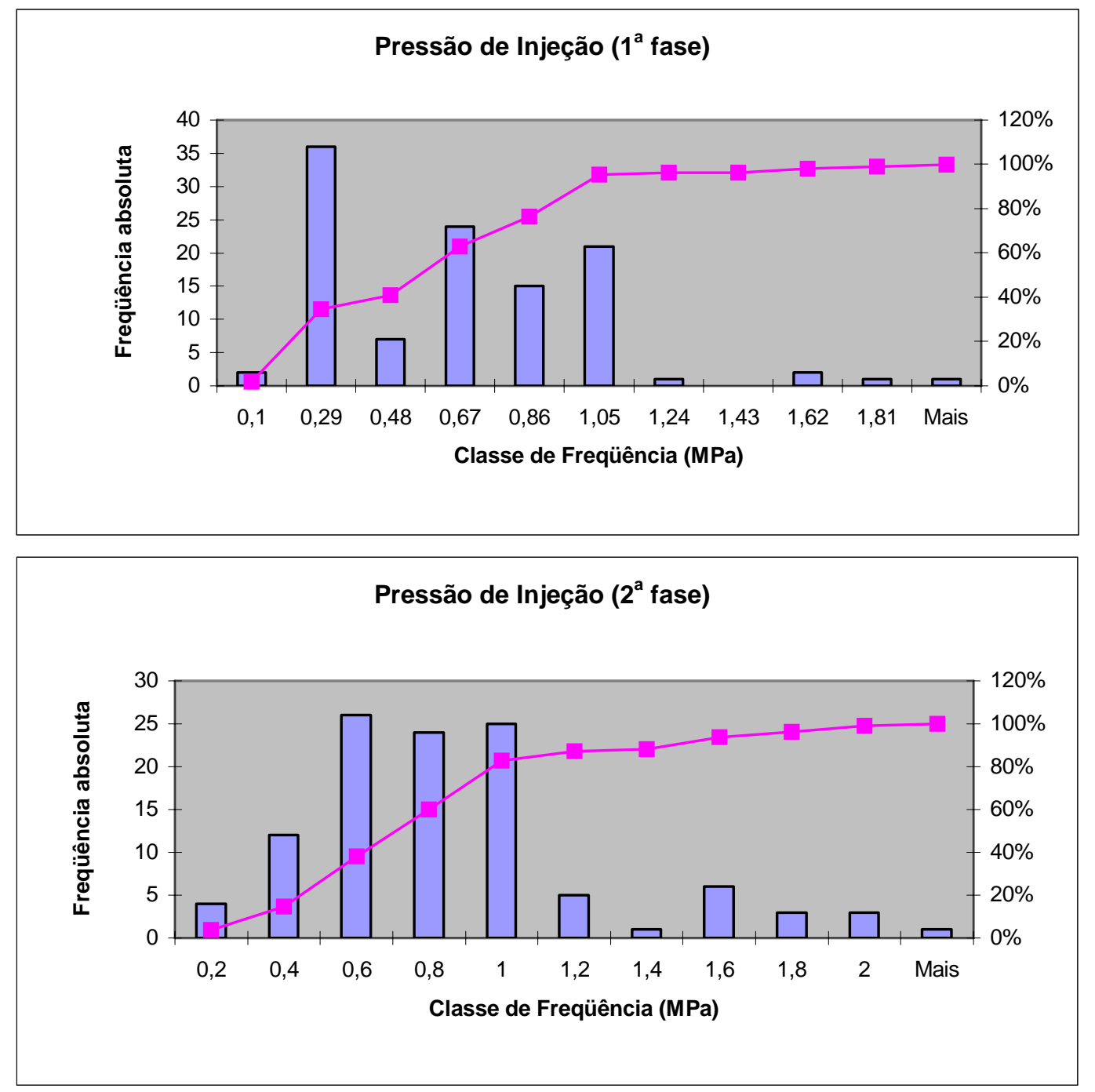

FIGURA 57 - Histogramas da pressão de injeção (Pi) nas duas fases de injeção.

Como o valor de Stat $\mathbf{t}$ é menor que o t crítico unicaudal, conclui-se que a hipótese $\mathrm{H}_{0}$ deve ser rejeitada, conseqüentemente é necessário admitidir a hipótese $\mathrm{H}_{1}$ como verdadeira. Nesse caso, depreende-se que a média da pressão de iniciação da ruptura da primeira fase (1,70 MPa) é menor que a média da segunda fase (2,90 MPa).

O teste $\mathbf{t}$ mostrou ainda que é muito baixa a probabilidade da estatística $\mathbf{t}$ (Stat t) ser maior que os valores do t crítico unicaudal $\left(3,41 \times 10^{-10} \%\right)$. Por esse motivo, a estatística indicou que é remota a chance da média da primeira fase ser maior que a média da segunda fase. 
Aplicando-se a mesma técnica de análise para a pressão de injeção, verifica-se:

- $\quad$ Stat $\mathbf{t}=-6,102$;

- $\quad$-t crítico = -1,289 (unicaudal).

Da comparação entre os valores, conclui-se que a média da pressão de injeção da primeira fase é inferior que a média da segunda fase.

Os aumentos de $70 \%$ e $50 \%$ verificados nas pressões da primeira para a segunda fase de injeção, respectivamente de iniciação da ruptura do maciço e de injeção na obra de Rasgão, comprovam, em parte, os relatos de GUIMARÃES FILHO (1984); OLIVEIRA \& FERREIRA (1982) e MOREIRA et al. (1990), que verificaram, nos tratamentos realizados com calda de cimento, acréscimos de até 100\% nos valores médios dessas pressões nas fases sucessivas do processo de injeção.

No presente estudo, os aumentos obtidos nos valores médios das pressões, da primeira fase para a seguinte, evidenciaram a melhoria alcançada por meio do tratamento com injeção de solo-cimento.

Acredita-se que, durante o processo de injeção, a aplicação da estatística poderá auxiliar na avaliação qualitativa e preliminar do tratamento, uma vez que sejam mantidas constantes as características reológicas das caldas utilizadas, bem como todos os critérios inicialmente adotados no tratamento. Para facilitar a distinção entre os valores das pressões de ruptura e de injeção, é necessário que a resistência da calda endurecida da bainha apresente valor superior ao do maciço terroso, conforme foi apresentado por SANTOS et. al. (1985) e exibido nas FIGURAS 26a e 26b. 
TABELA 17 - Resultados do teste $\mathbf{t}$ para duas amostras em par para médias das pressões de ruptura e de injeção, considerando duas fases de injeção.

\begin{tabular}{l|c|c|c|c}
\hline \multirow{2}{*}{ Estatística } & \multicolumn{3}{c}{ Pressão (MPa) } \\
\cline { 2 - 5 } & \multicolumn{2}{|c}{ Ruptura (Pr) } & \multicolumn{2}{|c}{ Injeção (Pi) } \\
& $\mathbf{1}^{\mathbf{a}}$ Fase & $\mathbf{2}^{\mathbf{a}}$ & $\mathbf{1}^{\mathbf{a}}$ Fase & $\mathbf{2}^{\mathbf{a}}$ \\
& & Fase & & Fase \\
\hline Média & 1,70 & 2,90 & 0,60 & 0,90 \\
Variância & 1,88 & 3,46 & 0,15 & 0,18 \\
Número de observações & 110 & 110 & 110 & 110 \\
Correlação de Pearson & 0,29 & - & 0,36 & - \\
Hipótese da diferença de média & 0 & - & 0 & - \\
Grau de liberdade & 109 & - & 109 & - \\
Stat t & $-6,768$ & - & $-6,102$ & - \\
Probabilidade Stat $\mathbf{t} \geq \mathbf{t}$ crítico unicaudal (\%) & $3,41 \times 10^{-10}$ & - & $8,15 \times 10^{-9}$ & - \\
$\mathbf{t}$ crítico (teste unicaudal) & $-1,289$ & - & $-1,289$ & - \\
\hline
\end{tabular}

\subsubsection{Análise das pressões nas diferentes ordens de tratamento}

As informações técnicas utilizadas nas análises seguintes estão apresentadas no ANEXO D e se referem às estatísticas das pressões de iniciação da ruptura e de injeção e aos histogramas que exibem as variações das pressões com a profundidade (cota em metro) no maciço terroso.

Para efetuar as análises estatísticas do comportamento das pressões nas diferentes faixas do terreno, foi necessário, inicialmente, estabelecer o intervalo dessas faixas, de maneira que formassem conjuntos contendo pelo menos cinco valores, passíveis de serem analisados por meio da estatística. Para isso, foram realizados os cálculos estatísticos preliminares, reunindo-se os valores de pressão em faixas de profundidades com intervalos de $2,5 \mathrm{~m}$, de $5,0 \mathrm{~m}$ e de $10,0 \mathrm{~m}$.

Os primeiros cálculos foram realizados reunindo-se os valores das pressões em intervalos de 10,0 m. Essa opção apresentou problemas, uma vez que na região central da 
tomada d'água da usina, onde os furos apresentavam profundidades em torno de $15 \mathrm{~m}$, foram formados apenas dois conjuntos de dados. Isto impediu a avaliação do comportamento das pressões com a profundidade.

Para aumentar o número de faixas de profundidades, visando avaliar as alterações nas pressões com a profundidade, o intervalo foi diminuído para 2,5 m. Esse intervalo mostrou-se apropriado para realizar as análises pretendidas. Todavia, com o prosseguimento dos estudos experimentais, verificou-se que, ao se estabelecer o intervalo de 5,0 m, obteve-se ainda uma boa quantidade de faixas de profundidades que permitiram realizar as análises necessárias. Além disso, foi verificado que os resultados alcançados na estatística descritiva, quanto às médias, ao desvio padrão, entre outros, apresentaram valores muito próximos daqueles conseguidos com intervalo de 2,5 m. Por esse motivo e para reduzir o número de cálculos necessários na análise estatística, optou-se pelo intervalo de 5,0 m. Portanto, foram estabelecidos nove intervalos de profundidades, identificados nas figuras e tabelas com números correspondentes às cotas (m) do terreno, a saber: 661 a 656; 656 a 651; 651 a 646; 646 a 641; 641 a 636; 636 a 631; 631 a 626; 626 a 621 e 621 a 616.

Nesta primeira análise, todos os valores de pressão de ruptura e de injeção foram organizados em linhas (primária, secundária e terciária) e nos nove intervalos de profundidades referidos.

Na FIGURA 58, pode-se verificar que a pressão de injeção mostra tendência de crescimento sistemático a partir da cota $661 \mathrm{~m}$ até 626 m, independentemente das camadas geológica-geotécnicas atravessadas. Por outro lado, a pressão de iniciação da ruptura mostra tendência em manter-se constante, da superfície até a cota $636 \mathrm{~m}$, elevando-se desta profundidade até atingir a cota $626 \mathrm{~m}$. No trecho compreendido entre as cotas 621 e $616 \mathrm{~m}$, as pressões de ruptura e de injeção mostraram valores médios menores que o trecho superior. Essa queda nas pressões deve estar associada à heterogeneidade da camada geológica, que apresenta, localmente, solo entre os núcleos rígidos de rocha alterada e matacões, como 
observado na sondagem SPR 33. Por outro lado, vale destacar que o conjunto de cinco valores de pressão de ruptura e cinco de injeção obtidos neste trecho, é muito pequeno para ser utilizado como representativo do nível de profundidade considerado.

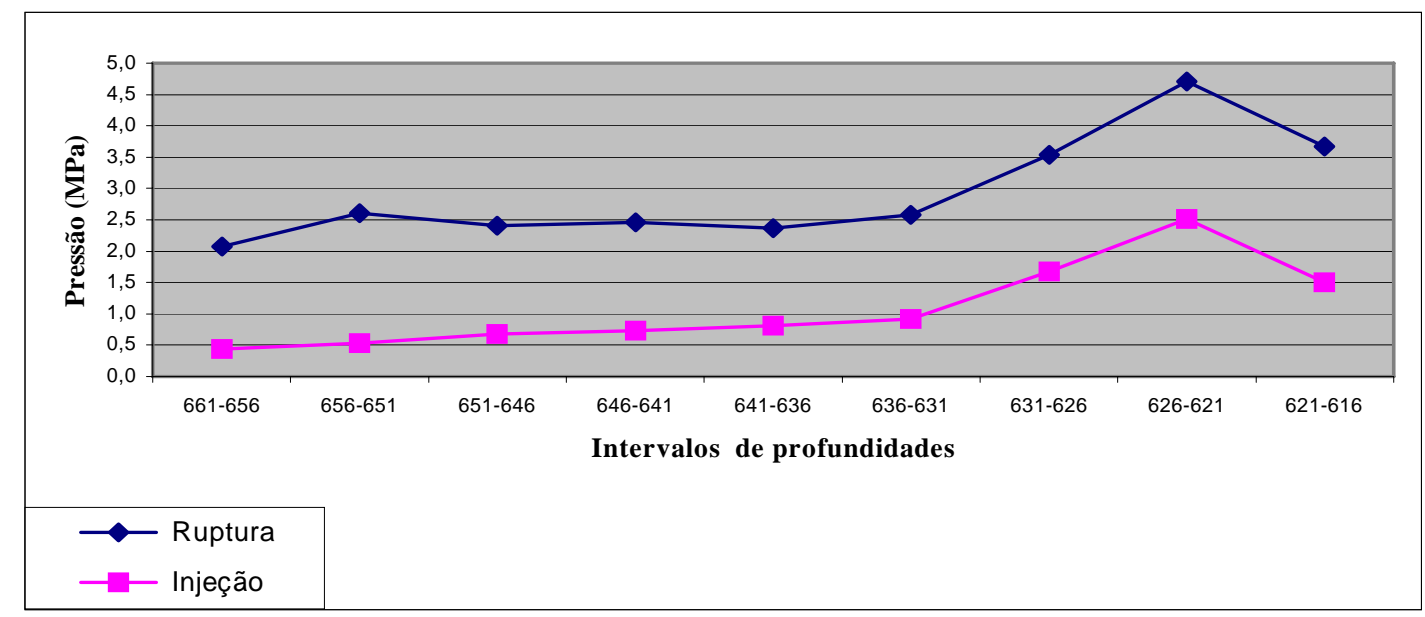

FIGURA 58 - Variações das pressões de ruptura e de injeção nos diferentes intervalos de profundidades, na cortina de vedação da obra de Rasgão.

A elevação da taxa de crescimento das pressões médias, observada nas duas curvas a partir do intervalo de profundidade 636-631, pode estar associada à mudança das características geológicas do terreno, que a partir deste trecho para baixo registra a camada inferior do solo residual de granitóides. No lado esquerdo da usina, o topo rochoso alterado aparece a partir da cota $631 \mathrm{~m}$, como foi observado na sondagem SPR 33 e no furo I 321 (FIGURA 36).

Na FIGURA 58, pode-se ver ainda certo paralelismo entre as curvas das pressões de iniciação da ruptura e de injeção, demonstrando uma possível correlação entre as pressões. Provavelmente, isto se deve à resistência mecânica oferecida pelo meio, composto pelo maciço, pela bainha e pela válvula-manchete. Acredita-se que nos intervalos onde a resistência do meio é maior, são requeridas maiores pressões para ruptura e injeção, e nos intervalos de menor resistência, são exigidas pressões menores. Com efeito, vale lembrar que 
as pressões de ruptura e de injeção formam pares de valores medidos na mesma válvulamanchete, portanto, sujeitos às mesmas condições físicas locais.

Os resultados apresentados no ANEXO D, bem como o gráfico da FIGURA 58, mostraram que as médias da pressão de iniciação da ruptura do maciço, no tratamento da usina de Rasgão, situaram-se entre 2,0 MPa e 5,0 MPa, acima da pressão média medida no tratamento da Barragem de Balbina, que ficou entre 0,6 MPa e 1,6 MPa. Essa diferença provavelmente se deve à geologia dos terrenos, assim como às modificações introduzidas no processo construtivo das bainhas da Barragem de Balbina. No relatório técnico dessa obra, foram citadas as variações encontradas na espessura das bainhas, tendo sido descritos casos de ausência da bainha (ELETRONORTE, 1984b).

De maneira semelhante, ficou comprovado também que os valores médios da pressão de injeção (entre 0,4 MPa e 2,5 MPa), na usina de Rasgão, superaram as médias da pressão obtidas no tratamento da fundação da Barragem de Balbina, com valores situados entre 0,4 MPa e 1,4 MPa (ELETRONORTE, 1984b).

Os cálculos estatísticos apresentados no ANEXO D, bem como os gráficos das FIGURAS 59 e 60 mostram as variações que ocorreram nas pressões de iniciação da ruptura e de injeção, nos diferentes intervalos de profundidades nas três linhas da cortina de vedação.

Para prosseguir com o estudo estatístico, por meio da técnica de análise de variância, tendo em vista a avaliação do comportamento das pressões de iniciação da ruptura e de injeção, ao longo dos diferentes níveis do terreno e nas três linhas injetadas, foi necessário desconsiderar 34 pares de valores de pressão das linhas primária e secundária. Tal medida foi tomada devido à ausência de valores de pressões nas três linhas e nos mesmos intervalos de profundidades, como mostram as FIGURAS 59 e 60. Por esse motivo, foram extraídas da análise de variância as pressões medidas nas válvulas-manchete localizadas nos seguintes intervalos de profundidades: 661 a 656, 631 a 626, 626 a 621 e 621 a 616. 


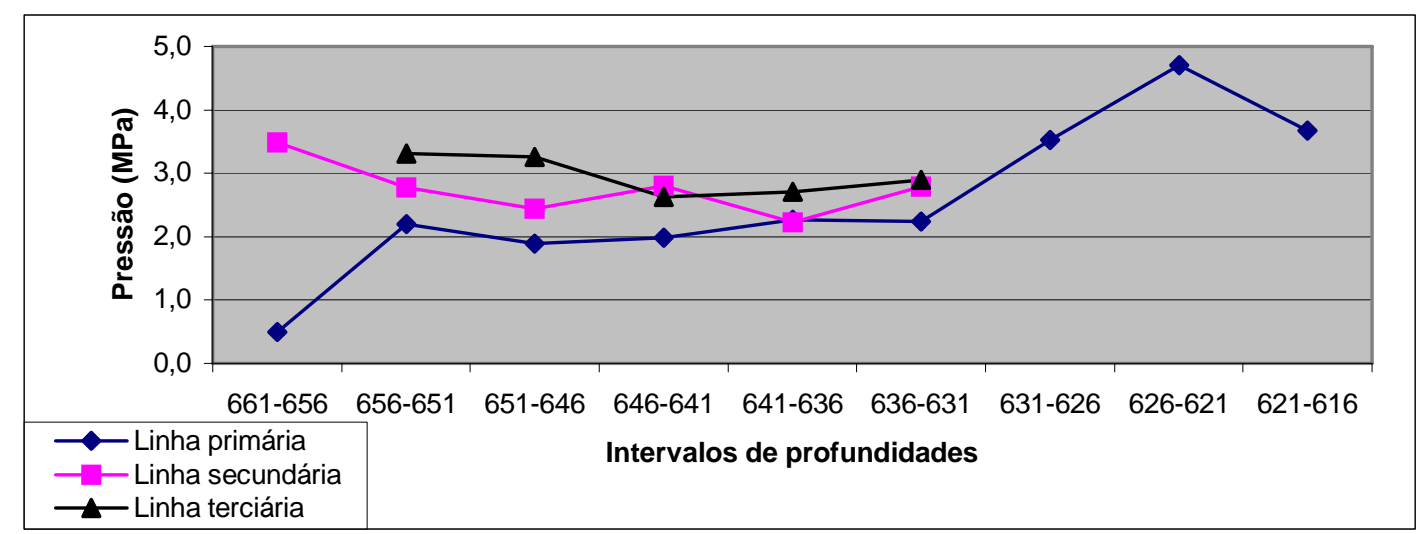

FIGURA 59 - Variação da pressão de ruptura, nas três linhas injetadas, nas duas camadas do solo residual.

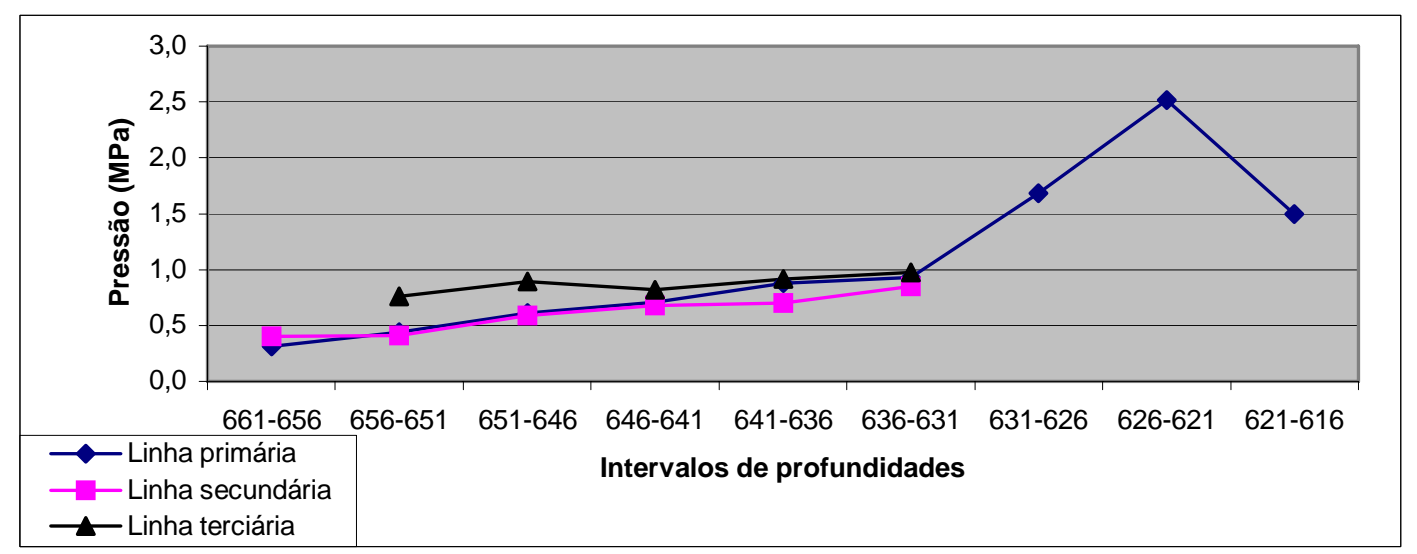

FIGURA 60 - Variação da pressão de injeção, nas três linhas injetadas, nas duas camadas do solo residual.

Definido o conjunto de valores, situados nas três linhas da cortina de vedação e entre os cinco intervalos de profundidades (do grupo 656 a 651 até o grupo 636 a 631), foram realizadas as análises estatísticas para avaliar o comportamento das pressões de iniciação da ruptura e de injeção, tendo como variáveis as três linhas injetadas e os cinco intervalos de profundidades. Estas análises foram efetuadas de duas maneiras, de acordo com os aspectos geológicos do terreno, a saber:

- Na primeira, foram considerados todos os registros obtidos nas injeções dos furos da cortina de vedação, independentemente da localização das válvulas-manchete, se na camada de solo residual superior ou inferior. Ou 
seja, foram desconsideradas as eventuais interferências geológicas ao longo dos perfis.

- Para a segunda análise, promoveu-se uma triagem nos valores das pressões, tendo sido extraídos da análise aqueles obtidos nas válvulas-manchete posicionadas na camada inferior do solo residual, devido às interferências dos núcleos rígidos de rocha alterada e matacões, presentes neste horizonte.

\subsubsection{Nas duas camadas do solo residual (superior e inferior)}

Nesta etapa, os estudos passaram a ser efetuados com um conjunto de 1.197 pares de valores de pressões obtidos nas válvulas distribuídas nas três linhas da cortina de vedação e em diferentes níveis do terreno, desconsiderando-se, portanto, a presença de duas camadas de solo residual. O ANEXO F contém os resultados da estatística descritiva obtidos das pressões de iniciação da ruptura do maciço e da injeção. Na TABELA 18 e FIGURA 61, foram destacadas as médias obtidas da pressão de iniciação da ruptura nas três linhas injetadas e nos diferentes intervalos de profundidades.

Nesta tabela, pode-se verificar que as médias da pressão de ruptura são crescentes da linha primária (2,11 MPa) para a secundária (2,60 MPa) e desta para a terciária (2,96 MPa). No entanto, ao observar os valores médios nos diferentes intervalos de profundidades, em cada uma das linhas, pode-se notar variações nos valores médios, ora para maior e ora para menor em relação ao trecho anterior, mostrando que não há evidências estatísticas de acréscimos ou decréscimos nas médias da pressão de iniciação da ruptura do maciço com a profundidade. Essa oscilação da pressão nos diferentes intervalos de profundidades também foi observada ao calcular as médias da pressão de ruptura das três linhas, como mostram os resultados da TABELA 19. 
A variação nas taxas de crescimento da pressão de ruptura entre as linhas primária e terciária, mostrada na TABELA 18, também confirmou a ocorrência das oscilações da pressão de iniciação da ruptura nos diferentes intervalos de profundidades.

As avaliações das tendências de crescimento da pressão de ruptura entre as linhas de injeção, bem como de sua inalterabilidade nos intervalos de profundidades, como mostram os resultados da TABELA 19, foram feitas por meio da análise de variância, com um nível de confiança de 90\% (WAENY, 1980).

TABELA 18 - Estatística da pressão de ruptura em cada uma das linhas injetadas, em diferentes intervalos de profundidades, nas duas camadas de solo residual de granitóides.

\begin{tabular}{c|c|c|c|c}
\hline \multirow{2}{*}{$\begin{array}{c}\text { Intervalos de } \\
\text { profundidades }\end{array}$} & \multicolumn{3}{|c|}{ Pressões nas Linhas (MPa) } & Aumento da LP \\
\cline { 2 - 4 } & Primária (LP) & Secundária (LS) & Terciária (LT) & 51,14 \\
\hline $656-651$ & 2,19 & 2,78 & 3,31 & 72,87 \\
$651-646$ & 1,89 & 2,43 & 3,25 & 32,32 \\
$646-641$ & 1,98 & 2,80 & 2,62 & 18,94 \\
$641-636$ & 2,27 & 2,22 & 2,70 & 29,46 \\
$636-631$ & 2,24 & 2,79 & 2,90 & 40,28 \\
\hline Média & 2,11 & 2,60 & 2,96 & \\
\hline
\end{tabular}

Foi aplicada a análise de variância com dois fatores sem repetição e de modelo fixo (denominada Anova no programa Microsoft Excel 97), cujos resultados alcançados são apresentados na TABELA 20. A escolha dessa técnica foi feita pela necessidade em se examinar as interferências causadas pelas variações na pressão média de uma linha para outra (um fator) e nos intervalos de profundidades (outro fator). E a opção pelo modelo fixo é devido à necessidade de se avaliar as variações que ocorrem na matriz formada pelas três linhas e cinco intervalos de profundidades.

Foram estabelecidas duas hipóteses iniciais para realizar a análise de variância $\left(\mathrm{H}_{01}\right.$ e $\left.\mathrm{H}_{02}\right)$, correspondentes a cada um dos fatores. Nestas hipóteses, foram admitidos que os valores médios em cada um dos fatores são inalteráveis; portanto, não há incrementos positivos ou negativos nesses valores médios, nas três linhas injetadas e nos diferentes intervalos de profundidades considerados. Para aceitar ou rejeitar qualquer uma das hipóteses 
estabelecidas, foi necessário calcular a estatística $\mathbf{F}$ e, em seguida, compará-la com Fcrítico, em cada uma das situações: linhas ou intervalos de profundidades. Nas comparações efetuadas, ao encontrar o valor de $\mathbf{F}$ menor que Fcrítico, ficou comprovado pela estatística que não havia evidência para rejeitar a hipótese $\mathrm{H}_{0}$. Neste caso, concluiu-se que os valores médios são indiferentes. No caso inverso, ou seja, F maior que Fcrítico a estatística mostrou evidência para rejeitar a hipótese $\mathrm{H}_{0}$. Nesta situação, concluiu-se que as médias variam de acordo com o fator considerado.

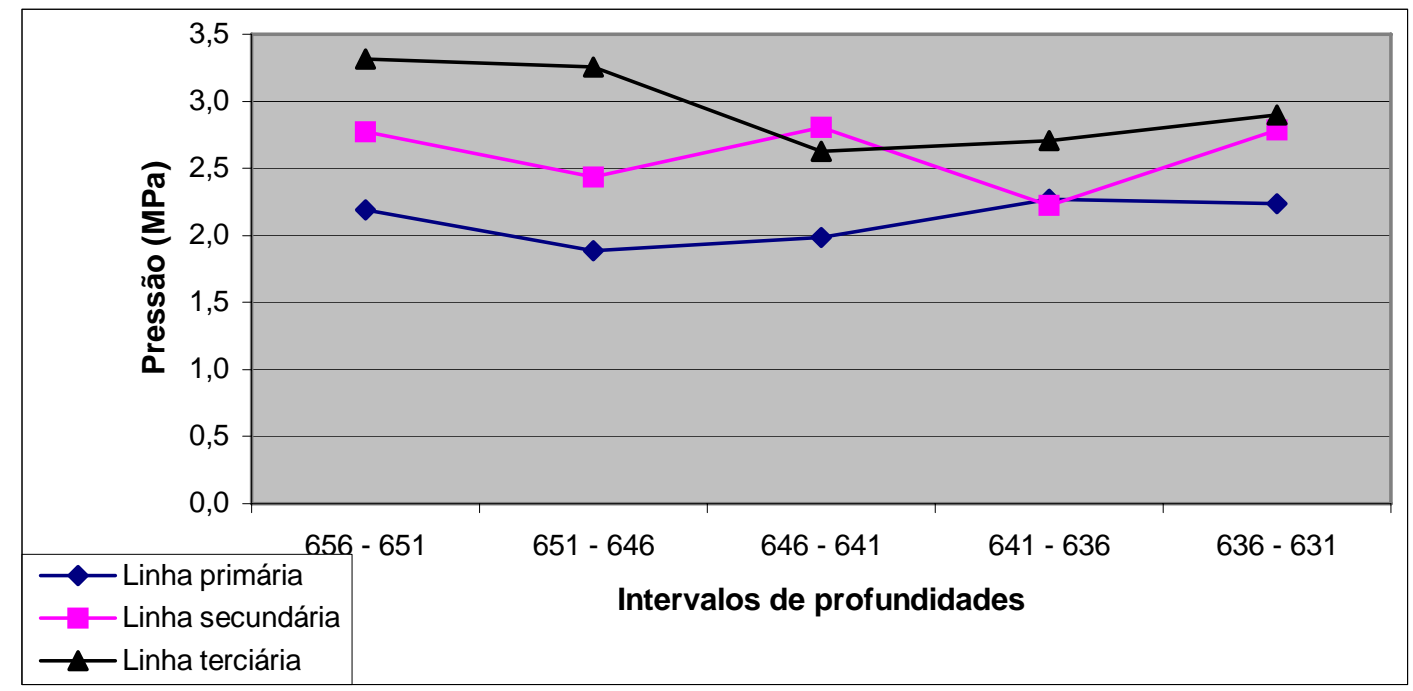

FIGURA 61 Variação dos valores médios da pressão de iniciação da ruptura com a profundidade, nas linhas primária, secundária e terciária, nas duas camadas do solo residual.

A estatística $\mathbf{F}$ é obtida pela divisão entre o valor do quadrado médio e o valor do quadrado médio do erro, enquanto que o Fcrítico é o valor extraído de tabelas estatísticas, mas pode ser calculado por meio da distribuição F, com erro de 10\% (ver APÊNDICE).

Com efeito, as duas hipóteses admitidas na análise de variância da pressão de iniciação da ruptura do maciço destinam-se a: a primeira $\left(\mathrm{H}_{01}\right)$ para avaliar o comportamento da pressão de ruptura, crescente ou não, nos diferentes intervalos de profundidades; e a segunda $\left(\mathrm{H}_{02}\right)$ foi estabelecida para certificar o crescimento indicado pelos valores médios 
(TABELA 19), quando o tratamento passou de uma linha para outra subseqüente. Estas hipóteses são:

1. $\mathrm{H}_{01}$ : a pressão média de ruptura do maciço, considerando os registros das três linhas injetadas, mantém-se inalterada com a profundidade;

2. $\mathrm{H}_{02}$ : a pressão média de ruptura do maciço, considerando os registros em todos os intervalos de profundidades, mantém-se inalterada nas três linhas.

TABELA 19 - Estatística e média da pressão de ruptura nas três linhas injetadas, em diferentes intervalos de profundidades, nas duas camadas de solo residual de granitóides.

\begin{tabular}{c|c|c|c|c}
\hline $\begin{array}{c}\text { Intervalos de } \\
\text { profundidades }\end{array}$ & $\begin{array}{c}\text { Número de } \\
\text { linhas }\end{array}$ & Soma (MPa) & Média (MPa) & Variância \\
\hline $656-651$ & 3 & 8,28 & 2,76 & 0,314 \\
$651-646$ & 3 & 7,57 & 2,52 & 0,473 \\
$646-641$ & 3 & 7,41 & 2,47 & 0,186 \\
$641-636$ & 3 & 7,20 & 2,40 & 0,069 \\
$636-631$ & 3 & 7,93 & 2,64 & 0,124 \\
\hline Linhas & Intervalos de & Soma (MPa) & Média (MPa) & Variância \\
\hline profundidades & 5 & 10,57 & 2,11 & 0,029 \\
Linha primária & 5 & 13,02 & 2,60 & 0,068 \\
Linha terciária & 5 & 14,79 & 2,96 & 0,098 \\
\hline
\end{tabular}

Os resultados dos cálculos da análise de variância são apresentados na TABELA 20, onde pode-se verificar que o valor da estatística $\mathbf{F}(0,905)$, relativo aos intervalos de profundidades, ficou abaixo do valor de Fcrítico $(2,806)$ correspondente. Neste caso, a estatística indicou que é necessário aceitar a hipótese $\mathrm{H}_{01}$, mostrando que a pressão média de ruptura não varia com a profundidade no terreno, como pode ser visto na FIGURA 61. Este resultado demonstrou que a variabilidade dos valores médios foi devida somente à variabilidade inerente das observações (erro), ou seja, há uma interação entre os valores das pressões e o terreno. 
TABELA 20 - Resultados da análise de variância com fator duplo sem repetição para a pressão de iniciação da ruptura do maciço.

\begin{tabular}{|c|c|c|c|c|c|c|}
\hline Fonte da variação & SQ & GL & $\mathbf{Q M}$ & $\mathbf{F}$ & $\begin{array}{c}\text { Valor-P } \\
(\%)\end{array}$ & Fcrítico \\
\hline Intervalo de profundidade & 0,244 & 4 & 0,061 & 0,905 & 0,504 & 2,806 \\
\hline Linhas & 1,798 & 2 & 0,899 & 13,337 & 0,002 & 3,113 \\
\hline Erro & 0,539 & 8 & 0,067 & & & \\
\hline Total & 2,581 & 14 & & & & \\
\hline $\begin{array}{l}\text { Nível de confiança de } 90 \% \\
\text { SQ = soma dos quadrados } \\
\text { GL = grau de liberdade }\end{array}$ & & Valo & $\begin{array}{l}\text { estatíst } \\
\text { robabili } \\
\text { ítico }=\mathrm{v}\end{array}$ & le & & \\
\hline
\end{tabular}

Os resultados da TABELA 20 mostraram ainda que o valor de $\mathbf{F}(13,337)$, relativo às linhas, ficou acima do valor de $\mathbf{F}$ crítico $(3,113)$. Por isso, foi necessário rejeitar a hipótese $\mathrm{H}_{02}$, o que levou a concluir que a pressão média de ruptura do maciço sofre alteração quando o tratamento por injeção passou de uma linha para a subseqüente.

A veracidade desta tendência da pressão média de iniciação da ruptura, em apresentar incrementos quando a injeção passou de uma linha para a seguinte, foi investigada por meio de teste estatístico. As pressões indicadas nas TABELAS 18 e 19 são valores médios, portanto não são absolutos. Por esse motivo, as comparações entre eles devem ser realizadas necessariamente por meio de análise estatística, como o teste de Scheffé, utilizado no presente estudo. Convém ressaltar que este teste não se aplica nos casos em que as médias não se alteram com o fator considerado, evidenciada pela análise de variância. Por esse motivo, o teste de Scheffé não foi realizado no caso da variação da pressão com a profundidade, já que o resultado da análise de variância indicou pela aceitação da hipótese $\mathrm{H}_{01}$.

Prosseguindo com a análise, o teste de Scheffé foi aplicado para realizar as comparações dos valores médios da pressão de iniciação da ruptura, duas a duas, das três linhas (Primária, Secundária e Terciária) injetadas. 
A aplicação do teste de Scheffé foi iniciada pelo cálculo do módulo mínimo da diferença entre as médias das pressões, em função dos números de intervalos de profundidades (k) e de linhas (n), do nível de erro $(\boldsymbol{\alpha})$, do Quadrado Médio do erro $(\mathbf{Q M})$ e da distribuição F, conforme mostra a eq.(40). Em seguida, foram calculados os módulos das diferenças entre os valores médios obtidos das linhas primária, secundária e terciária. Ao final dos cálculos foram realizadas as comparações entre os módulos obtidos. Foram considerados valores distintos aqueles maiores que o módulo mínimo (0,41 MPa) obtido na eq.(40). Os cálculos efetuados são apresentados a seguir:

$$
\left|\bar{x}_{. j}-\bar{x}_{. m}\right|>\sqrt{S_{R}^{2} \frac{2(n-1)}{k} F_{(n-1),(k-1)(n-1), \alpha}}
$$

onde:

$$
\begin{aligned}
& \mathbf{k}=5 \text { (número de intervalos de profundidades); } \\
& \boldsymbol{\alpha}=10 \% \text { (nível de erro); } \\
& \mathbf{n}=3 \text { (número de linhas: primária, secundária e terciária); } \\
& \mathbf{F}_{2, \mathbf{8 , 1 0} \%}=3,113 \text { (valor tabelado de F); } \\
& \mathbf{s}_{\mathbf{R}}^{2}=\text { QM erro }=0,067 \text {. }
\end{aligned}
$$

Calculando o módulo mínimo, tem-se:

$$
\left|\bar{x}_{. j}-\bar{x}_{. m}\right|>0,41 \mathrm{MPa}
$$

Os módulos das diferenças das pressões médias das linhas primária, secundária e terciária são:

$$
\left|\overline{\mathrm{x}}_{\mathrm{p}}-\overline{\mathrm{x}}_{\mathrm{S}}\right|=0,49 \mathrm{MPa}
$$




$$
\begin{aligned}
& \left|\overline{\mathrm{x}}_{\mathrm{p}}-\overline{\mathrm{x}}_{\mathrm{t}}\right|=0,85 \mathrm{MPa} \\
& \left|\overline{\mathrm{x}}_{\mathrm{S}}-\overline{\mathrm{x}}_{\mathrm{t}}\right|=0,36 \mathrm{MPa}
\end{aligned}
$$

onde:

$\bar{x}_{\mathrm{p}}, \overline{\mathrm{x}}_{\mathrm{S}}$ e $\overline{\mathrm{x}}_{\mathrm{t}}$ são valores médios da pressão de iniciação da ruptura do maciço, respectivamente, das linhas primária (2,11 MPa), secundária (2,60 MPa) e terciária (2,96 MPa).

Os resultados do teste de Scheffé mostraram que:

- a média da pressão de iniciação da ruptura da linha primária é inferior às das linhas secundária e terciária;

- não há distinção, do ponto de vista da estatística, entre as médias da pressão de ruptura da linha terciária e secundária.

Desconsiderando-se as eventuais interferências geológicas, as análises efetuadas mostraram que não há evidências estatísticas que comprovem a ocorrência de incrementos sucessivos na pressão de ruptura do maciço, quando o tratamento passou da linha primária para a secundária e desta para a terciária. Com efeito, os cálculos mostraram que a média da pressão de ruptura na linha primária foi inferior em relação às outras linhas injetadas.

Esse procedimento utilizado para analisar o comportamento da média da pressão de iniciação da ruptura, foi adotado no estudo da média da pressão de injeção. Assim, inicialmente foram realizados os cálculos estatísticos da pressão de injeção nas três linhas e nos diferentes intervalos de profundidades (ANEXO D). Em seguida, foram realizados os cálculos da variância e do teste de Scheffé. O resumo dos resultados obtidos pode ser visto nas TABELAS 21 e 22. 
Nos resultados apresentados na TABELA 21, pode-se notar que, diferentemente da pressão de iniciação da ruptura, há crescimento sistemático da pressão de injeção com a profundidade nas três linhas injetadas. Este fato pode ser visto também na representação gráfica dessas pressões ao longo dos diferentes intervalos de profundidades, exibidos na FIGURA 62.

Na TABELA 21, foram apresentadas ainda as taxas de aumento da pressão entre os valores médios das linhas primária e terciária, em cada um dos intervalos de profundidades, tendo sido encontrados os maiores crescimentos nas proximidades da superfície do terreno.

TABELA 21 - Estatística da pressão de injeção em cada uma das linhas, nos diferentes intervalos de profundidades, nas duas camadas de solo residual de granitóides.

\begin{tabular}{c|c|c|c|c}
\hline $\begin{array}{c}\text { Intervalos de } \\
\text { profundidades }\end{array}$ & \multicolumn{3}{|c|}{ Pressões nas Linhas (MPa) } & Aumento da LP \\
Primária (LP) & Secundária (LS) & Terciária (LT) & para (\%) \\
\hline $656-651$ & 0,44 & 0,41 & 0,76 & 72,73 \\
$651-646$ & 0,61 & 0,59 & 0,89 & 45,90 \\
$646-641$ & 0,71 & 0,68 & 0,82 & 15,49 \\
$641-636$ & 0,88 & 0,70 & 0,92 & 4,55 \\
$636-631$ & 0,93 & 0,85 & 0,97 & 4,30 \\
\hline Média & 0,71 & 0,65 & 0,87 & 22,54 \\
\hline
\end{tabular}

Nos gráficos da FIGURA 62, pode-se observar também a superioridade dos valores médios da linha terciária em relação às outras duas linhas, bem como uma ligeira inferioridade dos valores que compõem a linha secundária quando comparados aos da linha primária.

As determinações das médias e as variâncias da pressão de injeção das três linhas, nos diferentes intervalos de profundidades, bem como em cada uma das linhas injetadas, foram apresentados na TABELA 22. 
Na TABELA 23, são apresentados os resultados da análise de variância com fator duplo, sem repetição e de modelo fixo para a pressão de injeção. Nesta análise, foram admitidas as seguintes hipóteses:

1. $\mathrm{H}_{01}$ : a pressão média de injeção, considerando os registros das três linhas injetadas, mantém-se inalterada com a profundidade;

2. $\mathrm{H}_{02}$ : a pressão média de injeção, considerando os registros em todos os intervalos de profundidades, mantém-se inalterada nas três linhas.

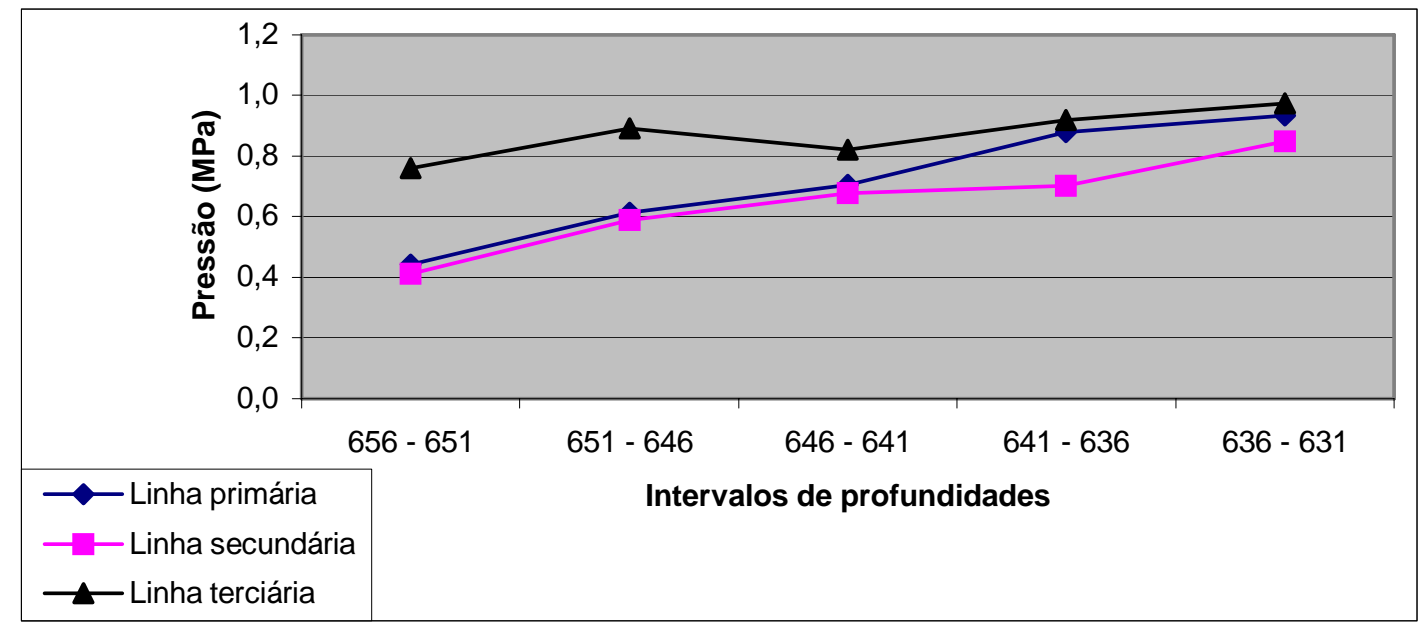

FIGURA 62 - Variação dos valores médios da pressão de injeção com a profundidade, nas linhas primária, secundária e terciária, nas duas camadas do solo residual.

TABELA 22 - Estatística e média da pressão de injeção nas três linhas injetadas, em diferentes intervalos de profundidades, nas duas camadas de solo residual de granitóides.

\begin{tabular}{c|c|c|c|c}
\hline $\begin{array}{c}\text { Intervalos de } \\
\text { profundidades }\end{array}$ & $\begin{array}{c}\text { Número de } \\
\text { linhas }\end{array}$ & Soma (MPa) & Média (MPa) & Variância \\
\hline $656-651$ & 3 & 1,61 & 0,54 & 0,037 \\
$651-646$ & 3 & 2,09 & 0.70 & 0,029 \\
$646-641$ & 3 & 2,21 & 0,74 & 0,006 \\
$641-636$ & 3 & 2,50 & 0,83 & 0,013 \\
$636-631$ & 3 & 2,75 & 0,92 & 0,004 \\
\hline Linhas & Intervalos de & Soma (MPa) & Média (MPa) & Variância \\
\hline
\end{tabular}




\begin{tabular}{c|c|c|c|c}
\cline { 2 - 5 } & profundidades & & & \\
\hline Linha primária & 5 & 3,57 & 0,71 & 0,040 \\
Linha secundária & 5 & 3,23 & 0,65 & 0,026 \\
Linha terciária & 5 & 4,36 & 0,87 & 0,007 \\
\hline
\end{tabular}

Na TABELA 23, observa-se que os valores da distribuição F, nos intervalos de profundidades e nas linhas, são maiores que os respectivos valores da distribuição Fcrítico. Estes resultados mostram que as duas hipóteses estabelecidas devem ser rejeitadas e, conseqüentemente, indicam que há evidências estatísticas que confirmam as variações dos valores médios da pressão de injeção nos intervalos de profundidades e nas linhas. Com a finalidade em reconhecer a validade destas evidências, foi aplicado o teste de Scheffé empregando-se a eq.(40).

TABELA 23 - Resultados da análise de variância com fator duplo, sem repetição e de modelo fixo para a pressão de injeção, nas duas camadas do solo residual.

\begin{tabular}{|c|c|c|c|c|c|c|}
\hline Fonte da variação & SQ & GL & QM & $\mathbf{F}$ & $\begin{array}{c}\text { Valor-P } \\
(\%)\end{array}$ & Fcrítico \\
\hline Intervalo de profundidade & 0,251 & 4 & 0,062 & 11,950 & 0,002 & 2,806 \\
\hline Linhas & 0,135 & 2 & 0,068 & 12,900 & 0,003 & 3,113 \\
\hline Erro & 0,042 & 8 & 0,005 & & & \\
\hline Total & 0,428 & 14 & & & & \\
\hline $\begin{array}{l}\text { Nível de confiança de } 90 \% \\
\text { SQ = soma dos quadrados }\end{array}$ & \multicolumn{6}{|c|}{$\begin{array}{l}\mathbf{F}=\text { estatística } \mathrm{F} \\
=\text { probabilidade }\end{array}$} \\
\hline $\begin{array}{l}\mathbf{G L}=\text { grau de liberdade } \\
\mathbf{Q M}=\text { quadrado médio }\end{array}$ & \multicolumn{6}{|c|}{ Fcrítico $=$ valor tabelado } \\
\hline
\end{tabular}

Para análise dessas variações da pressão de injeção entre as três linhas, foram utilizados os seguintes valores para os parâmetros da equação mencionada:

$$
\begin{aligned}
& \mathbf{k}=5 \text { (número de intervalos de profundidades); } \\
& \boldsymbol{\alpha}=10 \% \text { (nível de erro); } \\
& \mathbf{n}=3 \text { (número de linhas: primária, secundária e terciária); }
\end{aligned}
$$




$$
\begin{aligned}
& \mathbf{F}_{2,8,10 \%}=3,113 \text { (valor tabelado de F); } \\
& \mathbf{s}_{\mathbf{R}}^{2}=\text { QM erro }=0,005
\end{aligned}
$$

Calculando o módulo mínimo, tem-se:

$$
\left|\bar{X}_{. j}-\bar{x}_{. m}\right|>0,12 \mathrm{MPa}
$$

Os módulos das diferenças das pressões médias entre as linhas são:

$$
\begin{aligned}
& \left|\overline{\mathrm{x}}_{\mathrm{p}}-\overline{\mathrm{x}}_{\mathrm{s}}\right|=0,06 \mathrm{MPa} \\
& \left|\overline{\mathrm{x}}_{\mathrm{p}}-\overline{\mathrm{x}}_{\mathrm{t}}\right|=0,16 \mathrm{MPa} \\
& \left|\overline{\mathrm{x}}_{\mathrm{S}}-\overline{\mathrm{x}}_{\mathrm{t}}\right|=0,22 \mathrm{MPa}
\end{aligned}
$$

onde:

$\bar{x}_{\mathrm{p}}, \overline{\mathrm{x}}_{\mathrm{s}}$ e $\overline{\mathrm{x}}_{\mathrm{t}}$ são valores médios da pressão de injeção, respectivamente, das linhas primária $(0,71 \mathrm{MPa})$, secundária $(0,65 \mathrm{MPa})$ e terciária $(0,87$ $\mathrm{MPa})$.

Como os módulos das diferenças entre a linha terciária e as outras duas linhas (0,16 MPa e 0,22 MPa) são maiores que o módulo mínimo (0,12 MPa), o teste de Scheffé mostrou que a média da pressão de injeção na linha terciária é maior que as médias das linhas primária e secundária. Comprovou ainda que entre as médias das linhas primária (0,71 MPa) e secundária $(0,65)$, embora com valores distintos, não há diferença estatística.

Para analisar as variações da pressão média de injeção com a profundidade no terreno, foi utilizada a mesma técnica aplicada nas comparações anteriores. Entretanto, destaca-se que, nesta análise, o teste de Scheffé foi aplicado para avaliar a média da pressão nos diferentes intervalos de profundidades, e, por esse motivo, foi utilizada a fórmula da eq.(49). 


$$
\left|\overline{\mathrm{x}}_{\mathrm{j}}-\overline{\mathrm{x}}_{. \mathrm{m}}\right|>\sqrt{\mathrm{S}_{\mathrm{R}}^{2} \frac{2(\mathrm{k}-1)}{\mathrm{n}} \mathrm{F}_{(\mathrm{k}-1),(\mathrm{k}-1)(\mathrm{n}-1), \alpha}}
$$

onde:

$\mathbf{k}=5$ (número de intervalos de profundidades);

$\alpha=10 \%$ (nível de erro);

n = 3 (número de linhas: primária, secundária e terciária);

$\mathbf{F}_{\mathbf{4}, \mathbf{8 , 1 0} \%}=$ 2,806 (valor tabelado de F);

$\mathbf{s}_{\mathbf{R}}^{2}=\mathrm{QM}$ erro $=0,005$.

Calculando o módulo mínimo, tem-se:

$$
\left|\bar{X}_{. j}-\bar{x}_{. m}\right|>0,19 \mathrm{MPa}
$$

Os módulos das diferenças entre as médias dos intervalos de profundidades são:

$$
\begin{aligned}
& \left|\overline{\mathrm{x}}_{656-651}-\overline{\mathrm{x}}_{651-646}\right|=0,16 \mathrm{MPa} \\
& \left|\overline{\mathrm{x}}_{656-651}-\overline{\mathrm{x}}_{646-641}\right|=0,20 \mathrm{MPa} \\
& \left|\overline{\mathrm{x}}_{656-651}-\overline{\mathrm{x}}_{641-636}\right|=0,29 \mathrm{MPa} \\
& \left|\overline{\mathrm{x}}_{656-651}-\overline{\mathrm{x}}_{636-631}\right|=0,38 \mathrm{MPa} \\
& \left|\bar{x}_{651-646}-\bar{x}_{646-641}\right|=0,04 \mathrm{MPa} \\
& \left|\bar{x}_{651-646}-\bar{x}_{641-636}\right|=0,13 \mathrm{MPa} \\
& \left|\overline{\mathrm{x}}_{651-646}-\overline{\mathrm{x}}_{636-631}\right|=0,22 \mathrm{MPa} \\
& \left|\overline{\mathrm{x}}_{646-641}-\overline{\mathrm{x}}_{641-636}\right|=0,09 \mathrm{MPa} \\
& \left|\overline{\mathrm{x}}_{646-641}-\overline{\mathrm{x}}_{636-631}\right|=0,18 \mathrm{MPa} \\
& \left|\bar{x}_{641-636}-\bar{x}_{636-631}\right|=0,09 \mathrm{MPa}
\end{aligned}
$$

onde: 
$\overline{\mathrm{x}}_{656-651}, \quad \overline{\mathrm{x}}_{651-646}, \overline{\mathrm{x}}_{646-641}, \overline{\mathrm{x}}_{641-636}$ e $\overline{\mathrm{x}}_{636-631}$ são valores médios da pressão de injeção, respectivamente, nos intervalos 656-651 (0,54 MPa), 651-646 (0,70 MPa), 646-641 (0,74 MPa), 641-636 (0,83 MPa) е 636-631 (0,92 MPa).

De acordo com o critério do método de Scheffé, pode-se afirmar que há distinção entre as médias da pressão de injeção obtidas pelas eq.(52) a eq.(54) e eq.(57). Ao se verificar os resultados dos módulos obtidos, nota-se que os quatro primeiros (eq.51 a eq.54), os quais têm como referência a média da pressão de injeção no intervalo de profundidade 656-651 (0,54 MPa), as diferenças são seqüenciais e crescentes, à medida que as comparações são efetuadas com as médias dos intervalos mais profundos. Essa tendência também pode ser observada no conjunto de resultados obtidos pelas eq.(55) a eq.(57), assim como nas eq.(58) e eq.(59). Dessas observações, depreendem-se que as médias da pressão de injeção, considerando-se as três linhas injetadas (TABELA 22), são gradualmente crescentes com a profundidade. Com efeito, a estatística mostrou que as médias das populações de valores integrantes de dois intervalos de profundidades subseqüentes não são distintas.

\subsubsection{Na camada do solo residual superior}

Nesta segunda etapa da trabalho, a análise foi efetuada tomando-se como base a camada do solo residual superior. Nesta camada, foram coletadas informações de 924 válvulas-manchete distribuídas nas três linhas injetadas da cortina e em diferentes níveis do maciço. Essas informações foram utilizadas para avaliar o comportamento das pressões de iniciação da ruptura e de injeção. 
As médias, as medianas, as variâncias das amostras, entre outras, obtidas da pressão de iniciação da ruptura do maciço nas três linhas e em diferentes intervalos de profundidades, podem são apresentadas no ANEXO G. As médias da pressão de ruptura nas linhas consideradas e nos intervalos de profundidades são mostradas na TABELA 24. Na TABELA 25, são exibidas também as variâncias obtidas.

TABELA 24 - Valores médios da pressão de iniciação da ruptura do maciço, na camada superior do solo.

\begin{tabular}{|c|c|c|c|c|}
\hline \multirow{2}{*}{$\begin{array}{l}\text { Intervalos de } \\
\text { profundidades }\end{array}$} & \multicolumn{3}{|c|}{ Pressões nas linhas individuais (MPa) } & \multirow{2}{*}{$\begin{array}{c}\text { Aumento da } \\
\text { linha primária } \\
\text { para terciária } \\
(\%)\end{array}$} \\
\hline & Primária & Secundária & Terciária & \\
\hline $656-651$ & 1,13 & 2,53 & 3,31 & 193,80 \\
\hline $651-646$ & 1,64 & 2,44 & 3,29 & 101,00 \\
\hline $646-641$ & 2,11 & 2,48 & 2,67 & 26,00 \\
\hline $641-636$ & 2,52 & 1,97 & 2,82 & 11,90 \\
\hline Média & 1,85 & 2,35 & 3,02 & 83,17 \\
\hline
\end{tabular}

Ao comparar os valores médios de um mesmo intervalo de profundidade entre as linhas primária e terciária, verifica-se, nos resultados da TABELA 24, que as maiores taxas de acréscimos na pressão de ruptura ocorreram nos trechos situados na proximidades da superfície do terreno, com aumentos superiores a 190\%, decaindo com a profundidade para cerca de 12\% no intervalo 641-636. Entretanto, é importante observar que os valores médios nos intervalos superiores da linha terciária não são muito maiores que as médias dos níveis mais profundos.

Os resultados apresentados nas TABELAS 24 e 25 podem ser visualizados nos gráficos da FIGURA 63. Nesta figura, pode-se verificar, nitidamente, a ascensão da reta da linha primária com a profundidade. Os outros dois gráficos traçados mostram comportamentos irregulares, com tendências a um valor constante nos intervalos superiores e queda das médias nos intervalos inferiores. Ao comparar os gráficos desta figura, observa-se 
que os maiores aumentos na pressão de ruptura ocorreram nos intervalos de menor profundidade, como mostram os resultados apresentados na TABELA 24.

A elevação dos valores médios da pressão de ruptura, à medida que o processo de injeção passou da linha primária para a terciária, pode ser entendida como indício da melhoria na qualidade do maciço que adquiriu maior resistência mecânica. Além disso, a tendência das médias da pressão de ruptura em manter-se constante com a profundidade, pelo menos nos intervalos superiores das linhas secundária e terciária, pode ser entendida como certa homogeneização no maciço quanto à resistência mecânica, após a injeção.

TABELA 25 - Valores médios da pressão de iniciação da ruptura do maciço, nos intervalos de profundidades e nas linhas, na camada superior do solo.

\begin{tabular}{c|c|c|c|c}
\hline \multirow{2}{*}{$\begin{array}{c}\text { Intervalos de } \\
\text { profundidades }\end{array}$} & \multirow{2}{*}{$\begin{array}{c}\text { Número de } \\
\text { linhas }\end{array}$} & \multicolumn{2}{|c|}{ Pressões (MPa) } & \multirow{2}{*}{ Variância } \\
\cline { 3 - 4 } & 3 & Soma & Média & \\
\hline $656-651$ & 3 & 6,97 & 2,32 & 1,23 \\
$651-646$ & 3 & 7,37 & 2,45 & 0,68 \\
$646-641$ & 3 & 7,31 & 2,42 & 0,08 \\
$641-636$ & Intervalos de & \multicolumn{2}{|c|}{ Pressões (MPa) } & \multirow{2}{*}{ Variância } \\
\cline { 3 - 4 } Linhas & profundidades & Soma & Média & \\
\hline Linha primária & 4 & 7,40 & 1,85 & 0,36 \\
Linha secundária & 4 & 9,42 & 2,35 & 0,07 \\
Linha terciária & 4 & 12,09 & 3,02 & 0,11 \\
\hline
\end{tabular}

Por outro lado, as menores pressões de ruptura medidas na linha primária e junto à superfície, são devidas provavelmente à menor resistência mecânica do maciço natural. Essa característica do terreno pode ser comprovada pelos baixos índices de resistência à penetração (SPT = 2 a 4 golpes) obtidos nas sondagens, embora situadas cerca de $75 \mathrm{~m}$ da cortina de vedação. 


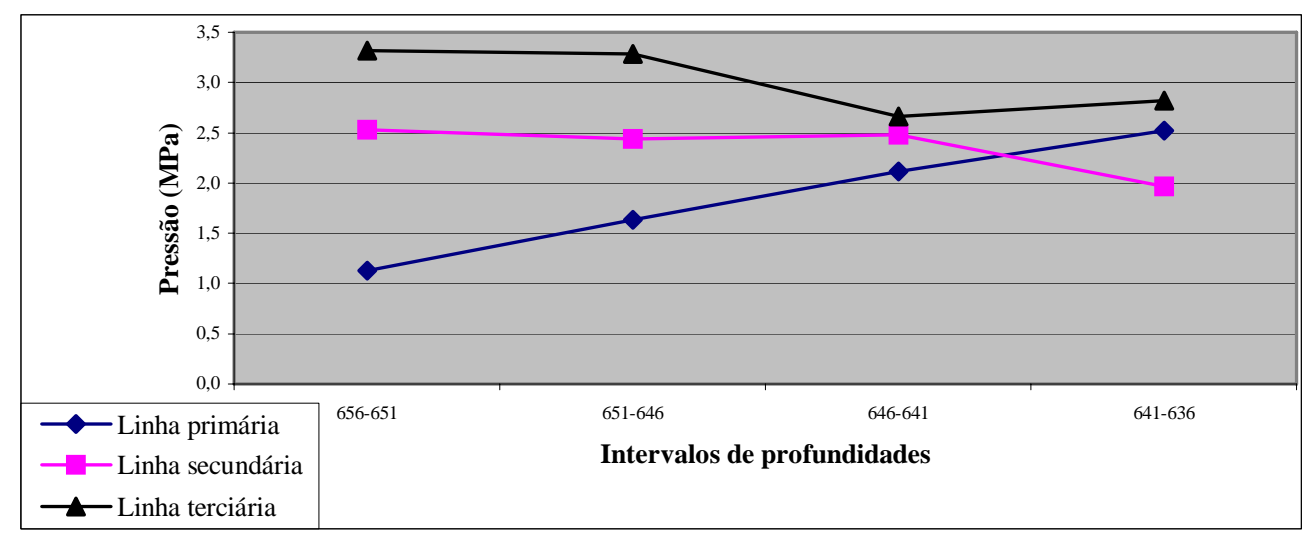

FIGURA 63 - Variação dos valores médios da pressão de iniciação da ruptura, com a profundidade, nas linhas primária, secundária e terciária, na camada superior do solo.

Para avaliar os resultados alcançados e apresentados na TABELA 25, recorreuse à análise da variância, com um nível de confiança de 90\%, como foi feito anteriormente. Os resultados obtidos são mostrados na TABELA 26. Para efetuar essa análise, foram admitidas as seguintes hipóteses:

1. $\mathrm{H}_{01}$ : que a pressão média de ruptura, considerando os registros das três linhas, mantém-se inalterada com a profundidade;

2. $\mathrm{H}_{02}$ : que a pressão média de ruptura, considerando todos os registros, mantém-se inalterada nas três linhas injetadas.

TABELA 26 - Resultados da análise de variância com fator duplo sem repetição e de modelo fixo para a pressão de iniciação da ruptura do maciço.

\begin{tabular}{l|c|c|c|c|c|c}
\hline \multicolumn{1}{c|}{ Fonte da variação } & SQ & GL & QM & F & $\begin{array}{c}\text { Valor-P } \\
\text { (\%) }\end{array}$ & Fcrítico \\
\hline Intervalo de profundidade & 0,031 & 3 & 0,010 & 0,039 & 0,988 & 3,288 \\
Linhas & 2,767 & 2 & 1,383 & 5,248 & 0,048 & 3,463 \\
Erro & 1,582 & 6 & 0,264 & & & \\
Total & 4,380 & 11 & & & \\
\hline Nível de confiança de 90\% & \multicolumn{7}{c}{ Falor-P = estatística F probabilidade } \\
SQ = soma dos quadrados & Fcrítico = valor tabelado \\
GL = grau de liberdade & QM = quadrado médio
\end{tabular}


O valor da estatística $\mathbf{F}(0,039)$ foi calculado através da relação entre os quadrados médios (QM) da pressão em cota e do erro, apresentando valor menor que a distribuição $\mathbf{F}$ tabelada (Fcrítico = 3,288). Este fato indica que não há evidência estatística para que a hipótese $\mathbf{H}_{\mathbf{0 1}}$ seja rejeitada.

Ainda na TABELA 26, pode-se notar outro indício estatístico para que a referida hipótese não seja rejeitada. Trata-se da alta probabilidade (valor-P $=98,8 \%$ ) para que essa hipótese seja aceita.

Também foram observados aumentos graduais nos valores médios da pressão de iniciação da ruptura do maciço, à medida que os trabalhos avançaram da linha primária até a terciária, como pode ser visto nos resultados apresentados na TABELA 24. As médias da pressão passaram de 1,85 MPa para 2,35 MPa e deste valor para 3,02 MPa, respectivamente, nas linhas primária, secundária e terciária.

O resultado da análise de variância indicou que a hipótese $\mathrm{H}_{02}$ deve ser rejeitada; em conseqüência, conclui-se que a pressão média de ruptura é diferente em pelo menos uma das linhas injetadas. Essa afirmação está fundamentada no valor de $\mathbf{F}(5,248)$ que é superior ao Fcrítico $(3,463)$, assim como no baixo valor da probabilidade (valor-P = 0,048\%) para se aceitar a hipótese $\mathbf{H}_{\mathbf{0 2}}$ (TABELA 26).

Para confirmar essa evidência estatística, bem como para determinar a possível seqüência entre os valores médios da pressão, foi necessário aplicar o teste de Scheffé. O módulo mínimo (0,956 MPa) foi calculado pela eq.(40), e os parâmetros utilizados foram:

$$
\begin{aligned}
& \mathbf{k}=4 \text { (número de grupos de profundidades); } \\
& \alpha=10 \% \text { (nível de erro); } \\
& \mathbf{n}=3 \text { (número de linhas: primária, secundária e terciária) } \\
& \mathbf{F}_{2, \mathbf{6}, \mathbf{1 0} \%}=3,463 \text { (valor tabelado de F); } \\
& \mathbf{s}_{\mathbf{R}}^{2}=\text { QM erro }=0,26 \text {. }
\end{aligned}
$$


Calculando a eq.(40), tem-se:

$$
\left|\bar{X}_{. j}-\bar{x}_{. m}\right|>0,956 \mathrm{MPa}
$$

Calculando-se os módulos das diferenças, a partir dos valores médios das linhas primária, secundária e terciária, tem-se os seguintes resultados:

$$
\begin{aligned}
& \left|\overline{\mathrm{x}}_{\mathrm{p}}-\overline{\mathrm{x}}_{\mathrm{S}}\right|=0,50 \mathrm{MPa} \\
& \left|\overline{\mathrm{x}}_{\mathrm{p}}-\overline{\mathrm{x}}_{\mathrm{t}}\right|=1,17 \mathrm{MPa} \\
& \left|\overline{\mathrm{x}}_{\mathrm{S}}-\overline{\mathrm{x}}_{\mathrm{t}}\right|=0,67 \mathrm{MPa}
\end{aligned}
$$

onde:

\footnotetext{
$\bar{x}_{p}, \bar{x}_{S}$ e $\bar{x}_{t}$ são valores médios da pressão de injeção, respectivamente, das linhas primária (1,85 MPa), secundária (2,35 MPa) e terciária (3,02 $\mathrm{MPa})$.
}

Os resultados estatísticos obtidos indicaram que o valor médio da linha terciária é superior em relação ao da linha primária, uma vez que o módulo obtido na eq.(63) (1,17 MPa) é maior que o módulo mínimo (0,956 MPa) calculado na eq.(61).

Por outro lado, os resultados indicaram ainda que o valor médio da pressão de ruptura da linha secundária (2,35 $\mathrm{MPa})$ não é distinto, do ponto de vista da estatística, da média da linha primária (1,85 MPa) e nem da terciária (3,02 MPa). A explicação desta afirmação encontra-se na inferioridade dos resultados dos cálculos das eq.(62) e eq.(64) em relação ao módulo mínimo. Disto depreende-se que entre a média da linha primária e a 
terciária a passagem é gradual, e o valor médio da linha secundária situa-se em posição intermediária.

Como foi explicado anteriormente, o teste de Scheffé não foi aplicado no caso da variação da pressão com a profundidade, devido aos resultados obtidos na análise de variância, que não evidenciaram alterações nas médias entre os intervalos de profundidades. Acredita-se que, como conseqüência da reunião dos valores da pressão de ruptura das três linhas, nos quatro intervalos de profundidades (TABELA 25), as médias resultantes sofreram forte influência das pressões altas das linhas secundária e terciária. Tal fato pode ser visto ao comparar os dados das TABELAS 24 e 25. Com efeito, ressalta-se que o crescimento contínuo da pressão de ruptura foi observado apenas no terreno natural, ou seja, na linha primária, como mostra o gráfico da FIGURA 63.

A mesma técnica utilizada nos cálculos para avaliar as variações da pressão de iniciação da fratura hidráulica do maciço foi aplicada também no estudo da pressão de injeção. Portanto, a análise foi iniciada com os resultados da estatística descritiva, em seguida foram determinadas as variâncias e finalmente aplicou-se o teste de Scheffé para assegurar os resultados obtidos.

As determinações da estatística descritiva da pressão de injeção na camada superior do solo residual, como a média, a mediana, o desvio padrão, a variância da amostra, entre outras, podem ser verificadas no ANEXO G.

As médias obtidas da pressão de injeção nas três linhas e nos intervalos de profundidades são mostrados na TABELA 27, onde pode-se observar que as pressões crescem com a profundidade, exceto no intervalo de profundidade 646 a 641 da linha terciária. Pode-se notar ainda que a média na linha terciária (0,86 MPa) é superior em relação às outras duas, e que houve inversão entre os valores médios das linhas primária (0,68 MPa) e secundária (0,59 MPa). 
Acréscimos maiores nas médias da pressão de injeção, entre as linhas primária e terciária, ocorreram nas proximidades da superfície do terreno (67,40\%), da mesma forma que no caso da pressão de ruptura (TABELA 24), porém em proporções menores (TABELA 27). Na FIGURA 64, as variações das pressões médias entre linhas e nos intervalos de profundidades estão representadas em forma de gráfico.

TABELA 27 - Valores médios da pressão de injeção em cada uma das linhas, nos diferentes intervalos de profundidades, na camada superior do solo.

\begin{tabular}{c|c|c|c|c}
\hline \multirow{2}{*}{$\begin{array}{c}\text { Intervalos de } \\
\text { Profundidades }\end{array}$} & Primária & Secundária & Terciária & $\begin{array}{c}\text { Aumento da } \\
\text { linha primária } \\
\text { para a terciária } \\
\text { (\%) }\end{array}$ \\
\hline 656 a 651 & 0,45 & 0,41 & 0,76 & 67,40 \\
651 a 646 & 0,63 & 0,60 & 0,90 & 42,20 \\
646 a 641 & 0,73 & 0,65 & 0,83 & 14,30 \\
641 a 636 & 0,90 & 0,69 & 0,96 & 6,60 \\
\hline Média & 0,68 & 0,59 & 0,86 & 32,62 \\
\hline
\end{tabular}

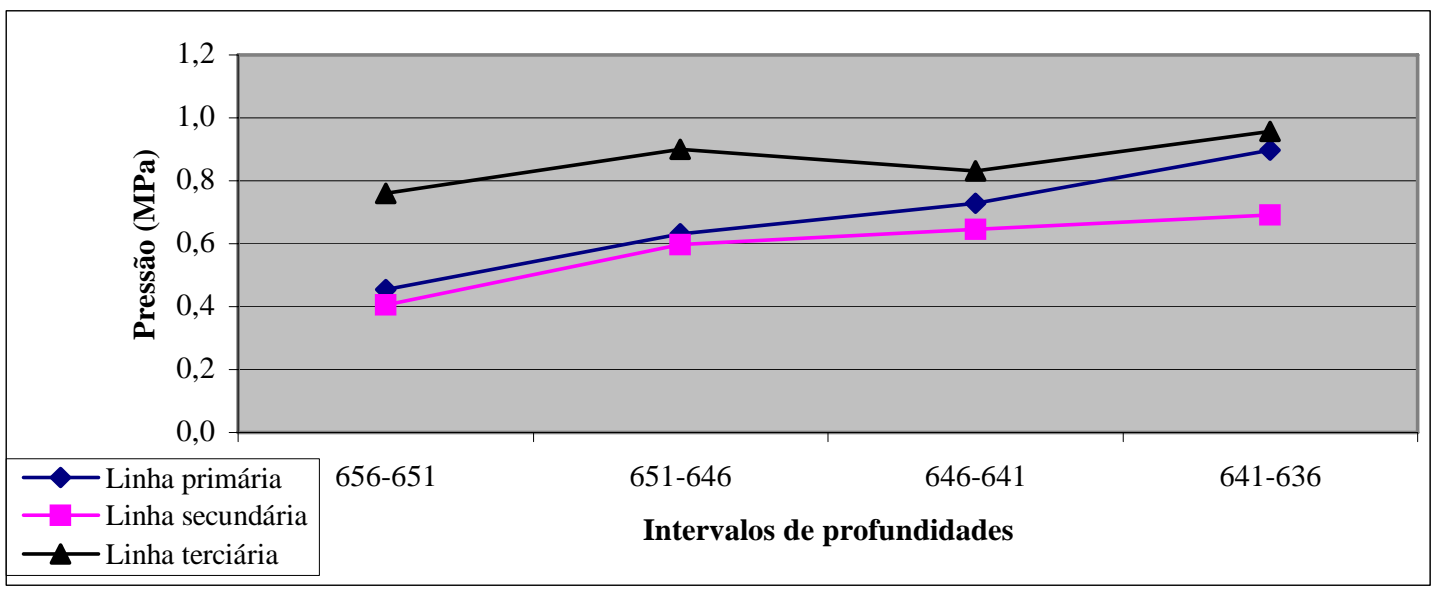

FIGURA 64 - Variações dos valores médios da pressão de injeção com a profundidade nas linhas primária, secundária e terciária, na camada superior do solo.

A análise de variância da pressão de injeção, considerando como fator de variação as linhas injetadas e os intervalos de profundidades, foi efetuada admitindo-se as seguintes hipóteses: 
1. $\mathrm{H}_{01}$ : que a pressão média de injeção, considerando os registros das três linhas, mantém-se inalterada com a profundidade;

2. $\mathrm{H}_{02}$ : que a pressão média de injeção, considerando todos os registros, mantém-se inalterada nas três linhas injetadas.

Nos intervalos de profundidades considerados, as maiores variâncias foram observadas nas médias das pressões situadas nas proximidades da superfície do terreno (TABELA 28). Convém destacar que essas variâncias são menores que as obtidas anteriormente (TABELA 25), quando foram desconsiderados os aspectos geológicos do terreno.

Na TABELA 28, pode-se notar que as maiores variâncias foram encontradas na linha primária.

Para confirmar os resultados alcançados, foram realizadas novas análises estatísticas à semelhança da avaliação efetuada para a pressão de iniciação da ruptura do maciço. Na TABELA 29, foram expostos os resultados dos cálculos da análise de variância (Anova) com fator duplo sem repetição (intervalos de profundidades e linhas). Na referida tabela, os resultados do cálculo de $\mathbf{F}$ (11,59 e 18,63), tanto nos intervalos de profundidade como nas linhas, apresentaram valores maiores que os respectivos Fcrítico $(3,29$ e 3,46). Tal fato indica que a média em pelo menos uma das linhas é diferente em relação às outras duas, assim como, a média em pelo menos um dos intervalos de profundidade também é diferente dos demais.

Outra evidência encontrada para a rejeição das hipóteses $\mathbf{H}_{\mathbf{0 1}}$ e $\mathbf{H}_{\mathbf{0 2}}$ foram as baixas probabilidades (valor-P 0,007 \% e 0,003 \%) para aceitá-las.

Prosseguindo com a análise, foi aplicado o teste de Scheffé para avaliar os resultados obtidos, bem como para verificar a possibilidade de ocorrer a seqüência das 
médias da pressão de injeção entre as três linhas. Para isso, foi empregada a eq.(40), com os seguintes parâmetros:

TABELA 28 - Valores médios da pressão de injeção, nos intervalos de profundidades e nas linhas, na camada superior do solo.

\begin{tabular}{c|c|c|c|c}
\hline \multirow{2}{*}{$\begin{array}{c}\text { Intervalos de } \\
\text { Profundidades }\end{array}$} & \multirow{2}{*}{$\begin{array}{l}\text { Número de } \\
\text { linhas }\end{array}$} & \multicolumn{2}{|c|}{ Pressões (MPa) } & \multirow{2}{*}{ Variância } \\
\cline { 3 - 4 } & 3 & 1,62 & Média & \\
\hline $656-651$ & 3 & 2,13 & 0,54 & 0,04 \\
$651-646$ & 3 & 2,21 & 0,71 & 0,03 \\
$646-641$ & 3 & 2,55 & 0,74 & 0,01 \\
$641-636$ & Intervalos de & \multicolumn{2}{|c|}{ Pressões (MPa) } & \multirow{2}{*}{ Variância } \\
\cline { 3 - 4 } Linhas & profundidades & Soma & Média & \\
& & 2,71 & 0,68 & 0,04 \\
\hline Linha primária & 4 & 2,34 & 0,59 & 0,02 \\
Linha secundária & 4 & 3,45 & 0,86 & 0,01 \\
\hline Linha terciária & 4 & &
\end{tabular}

$\mathbf{k}=4$ (número de grupos de profundidades);

$\alpha=10 \%$ (nível de erro);

n = 3 (número de linhas: primária, secundária e terciária);

$\mathbf{F}_{2,6,10 \%}=3,463$ (valor tabelado de F);

$\mathbf{s}_{\mathbf{R}}^{2}=\mathrm{QM}$ erro $=0,004$.

TABELA 29 - Resultados da análise de variância com fator duplo sem repetição para a pressão de injeção do maciço.

\begin{tabular}{l|c|c|c|c|c|c}
\hline \multicolumn{1}{c|}{ Fonte da variação } & SQ & GL & QM & F & $\begin{array}{c}\text { Valor-P } \\
(\%)\end{array}$ & Fcrítico \\
\hline Intervalo de profundidade & 0,147 & 3 & 0,049 & 11,593 & 0,007 & 3,288 \\
Linhas & 0,158 & 2 & 0,079 & 18,632 & 0,003 & 3,463 \\
Erro & 0,026 & 6 & 0,004 & & & \\
Total & 0,331 & 11 & & & & \\
\hline Nível de confiança de 90\% & \multicolumn{5}{c}{ Falor-P = estatística F } \\
SQ = soma dos quadradosilidade \\
GL = grau de liberdade \\
QM = quadrado médio
\end{tabular}


Ao calcular a eq.(40), tem-se:

$$
|\bar{x} \cdot j-\bar{x} . m|>0,121 \mathrm{MPa}
$$

Ao calcular os módulos das diferenças, a partir das médias das linhas primária, secundária e terciária, obtém-se os seguintes valores:

$$
\begin{aligned}
& \left|\overline{\mathrm{x}}_{\mathrm{p}}-\overline{\mathrm{x}}_{\mathrm{S}}\right|=0,09 \mathrm{MPa} \\
& \left|\overline{\mathrm{x}}_{\mathrm{p}}-\overline{\mathrm{x}}_{\mathrm{t}}\right|=0,18 \mathrm{MPa} \\
& \left|\overline{\mathrm{x}}_{\mathrm{S}}-\overline{\mathrm{x}}_{\mathrm{t}}\right|=0,27 \mathrm{MPa}
\end{aligned}
$$

onde:

$\overline{\mathrm{x}}_{\mathrm{p}}, \overline{\mathrm{x}}_{\mathrm{S}}$ e $\overline{\mathrm{x}}_{\mathrm{t}}$ são valores médios da pressão de injeção, respectivamente, das linhas primária (0,68 MPa), secundária (0,59 MPa) e terciária (0,86 $\mathrm{MPa})$.

Como pode ser constatado, o teste evidenciou a superioridade do valor médio da pressão de injeção da linha terciária em relação às outras duas linhas, conforme ilustram os módulos das diferenças. Por outro lado, indicou também que não há evidências estatísticas para que seja feita distinção entre os valores médios das linhas primária e secundária.

Para análise comparativa entre as médias da pressão de injeção em diferentes intervalos de profundidades, foi aplicado novamente o teste de Scheffé. O cálculo do módulo mínimo foi feito empregando-se a eq.(49), com os parâmetros discriminados:

$\mathbf{k}=4$ (número de grupos de profundidades); 


$$
\begin{aligned}
& \boldsymbol{\alpha}=10 \% \text { (nível de erro); } \\
& \mathbf{n}=3 \text { (número de linhas: primária, secundária e terciária); } \\
& \mathbf{F}_{3,6,10 \%}=3,289 \text { (valor tabelado de F); } \\
& \mathbf{s}_{\mathbf{R}}^{2}=\text { QM erro }=0,004 \text {. }
\end{aligned}
$$

Substituindo-se os valores na eq.(49), tem-se que:

$$
\left|\bar{x}_{j .}-\bar{x}_{m .}\right|>0,162 \mathrm{kgf} / \mathrm{cm}^{2}
$$

Calculando-se os módulos das diferenças entre os valores médios da pressão de injeção dos quatro intervalos de profundidades (TABELA 28), obtém-se:

$$
\begin{aligned}
& \left|\bar{x}_{656-651}-\bar{x}_{651-646}\right|=0,17 \mathrm{MPa} \\
& \left|\bar{x}_{656-651}-\bar{x}_{646-641}\right|=0,20 \mathrm{MPa} \\
& \left|\bar{x}_{656-651}-\bar{x}_{641-636}\right|=0,31 \mathrm{MPa} \\
& \left|\bar{x}_{651-646}-\bar{x}_{646-641}\right|=0,03 \mathrm{MPa} \\
& \left|\bar{x}_{651-646}-\bar{x}_{641-636}\right|=0,14 \mathrm{MPa} \\
& \left|\bar{x}_{646-641}-\bar{x}_{641-636}\right|=0,11 \mathrm{MPa}
\end{aligned}
$$

onde:

$$
\bar{x}_{656-651}=\text { média da pressão no intervalo de profundidade } 656 \text { a } 651 .
$$

Nota-se que nos três primeiros módulos (eq. 70 a eq.72), tendo como referência a média no intervalo 656 a 651 (0,54 MPa), as diferenças são crescentes e o teste indicou que os valores médios são distintos entre si. Todavia, ao tomar como referência os valores médios dos intervalos de profundidades 651 a $646(0,71 \mathrm{MPa})$ e 646 a $641(0,74 \mathrm{MPa})$, o teste não indicou distinção estatística entre as médias comparadas, ou seja, os resultados das eq.(73), eq.(74) e eq.(75) são inferiores em relação ao valor do módulo mínimo (eq.69). Daí pode-se concluir que, embora as médias da pressão de injeção sejam crescentes com a 
profundidade, variando de 0,54 MPa a 0,85 MPa (TABELA 28), a estatística não diferencia esses valores médios. Vale destacar que a variação crescente da pressão de injeção com a profundidade foi observada nas linhas primária e secundária, diferenciando-se da observação efetuada na pressão de ruptura que mostrou crescimento contínuo apenas na linha primária.

\subsubsection{Fraturamento hidráulico}

Durante a construção da cortina de vedação da Usina de Rasgão, foram realizados ensaios de fraturamento hidráulico em 48 válvulas de 25 furos. Esses ensaios tiveram como objetivo a avaliação do comportamento da pressão aplicada no momento da iniciação da ruptura do maciço, bem como durante a propagação dessa fratura induzida. Os trechos e as válvulas foram escolhidas aleatoriamente, localizadas em diferentes cotas do terreno da camada superior do solo residual e nas diferentes linhas injetadas. As informações técnicas de campo são apresentadas no ANEXO E.

No mesmo campo de prova onde foram realizados os estudos geofísicos, foram aproveitadas as injeções efetuadas em 50 válvulas, instaladas em 5 furos com 12,45 m de profundidade, para analisar a forma de ocorrência das fraturas induzidas. Destaca-se que, neste local, foram empregados corantes nas caldas injetadas para verificar possíveis relações entre as fraturas produzidas nos diferentes furos.

O ensaio do fraturamento consistiu em injetar um volume de calda superior ao

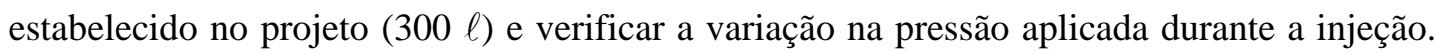
Ao iniciar a abertura da bainha, notou-se que a pressão aplicada crescia gradualmente até alcançar um valor máximo e, no momento da ruptura do maciço, decrescia rapidamente até atingir o valor da pressão de injeção, mantendo-se constante durante toda a fase de introdução da calda de solo-cimento. Decorrido certo tempo, independentemente do volume já injetado, a pressão voltava a subir até um valor máximo, superior ao da iniciação da 
ruptura do maciço, para decair rapidamente e retornar ao valor inicial da pressão de injeção. A FIGURA 65 mostra, em gráfico, esquematicamente, o comportamento da pressão aplicada ao longo do tempo.

Para realizar as análises da variação das pressões, mais uma vez recorreu-se aos recursos matemáticos oferecidos pela estatística e disponíveis no Microsoft Excel 97. Após esses cálculos, buscou-se, ainda na estatística (COSTA NETO, 1977; LANDIM, 1998), ferramentas para analisar e promover testes comparativos com a intenção de certificar os resultados alcançados, para um nível de confiança de 95\% (WAENY, 1980). A necessidade de se realizar esses testes deve-se ao fato das médias obtidas (pressões) resultarem de cálculos estatísticos, tratando-se portanto de valores representativos.

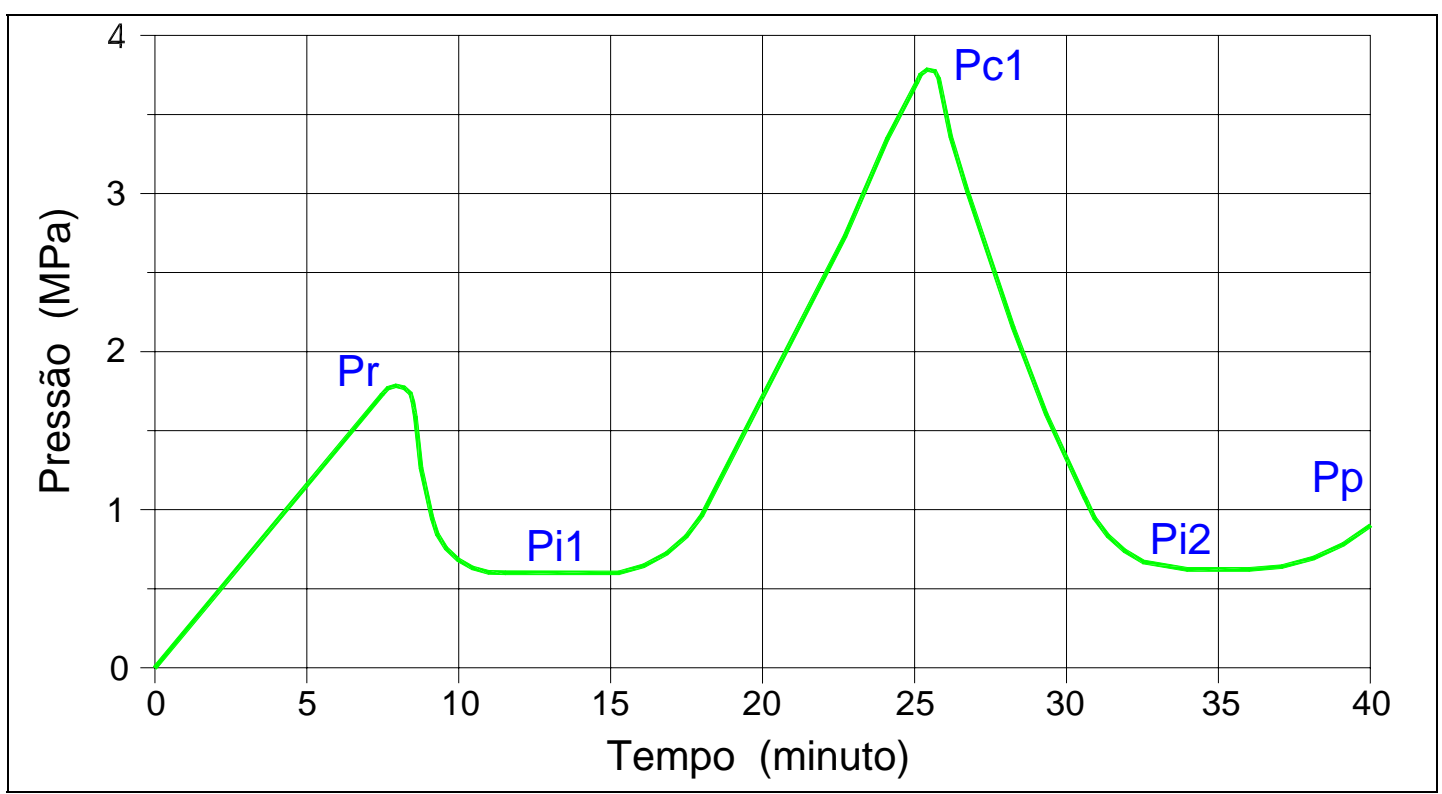

FIGURA 65 - Variação da pressão média durante os ensaios de ruptura hidráulica do maciço terroso. $\mathrm{Pr}$ = pressão de iniciação da ruptura do maciço; Pi1 e Pi2 = pressão de injeção; Pc1 = pressão da nova ruptura ou reabertura da primeira; e Pp = pressão de paralisação da injeção.

Para avaliar as espessuras das caldas endurecidas e a forma de ocorrência das fraturas induzidas durante a construção da cortina de vedação, foram inspecionadas as paredes de quatro poços localizados a jusante dessa cortina. Outras observações também 
foram efetuadas nas paredes de uma trincheira que foi escavada ao longo dos furos injetados no campo de prova.

Antes de partir para as análises e discussões dos resultados, é necessário apresentar algumas condições e hipóteses admitidas no estudo do fraturamento hidráulico:

- os traços das caldas da bainha e da injeção foram mantidos constantes durante todo o processo do ensaio;

- o diâmetro das perfurações, as válvulas-manchete e os equipamentos de injeção, entre outros itens relacionados no trabalho executivo, não foram alterados;

- o fraturamento hidráulico foi realizado em terreno situado acima do nível d’água;

- no momento da iniciação da ruptura do maciço, ou durante a propagação da fratura induzida, admitiu-se que a calda utilizada é do tipo não compressível, ou seja, a pressão aplicada e medida no manômetro corresponde àquela necessária para ruptura do conjunto válvula, bainha e maciço terroso;

- fundamentado nos estudos de QUADROS (1982), CRUZ (no prelo) e BARRADAS (1985), foi admitido que a calda de solo-cimento comporta-se como fluido de Newton e o escoamento do fluxo ocorre em regime laminar;

- a pesquisa foi efetuada com a pressão medida no manômetro; portanto, é a resultante do somatório da pressão efetiva de injeção, das perdas provocadas pelas válvula-manchete, pelas fraturas na bainha e pelas irregularidades na parede do maciço terroso.

Os resultados da estatística descritiva de cada uma das pressões medidas durante os ensaios são mostrados na TABELA 30. As pressões anotadas nestes ensaios foram: da iniciação da ruptura do maciço terroso $\left(\mathrm{P}_{\mathrm{r}}\right)$; da injeção da calda de solo-cimento $\left(\mathrm{P}_{\mathrm{i}}\right)$; da nova ruptura do maciço ou propagação da primeira fratura $\left(\mathrm{P}_{\mathrm{c}}\right)$ e da paralisação da injeção $\left(\mathrm{P}_{\mathrm{p}}\right)$. As médias resultantes dessas pressões foram:

- $\mathrm{P}_{\mathrm{r}}=1,80 \mathrm{MPa}$; 
- $\mathrm{P}_{\mathrm{i}}=0,57 \mathrm{MPa}$;

- $\mathrm{P}_{\mathrm{c}}=3,80 \mathrm{MPa}$;

- $\mathrm{P}_{\mathrm{p}}=0,97 \mathrm{MPa}$.

As maiores variações nas pressões ocorreram na de ruptura e na de propagação das fraturas $\left(\mathrm{P}_{\mathrm{r}}\right.$ e $\mathrm{P}_{\mathrm{c}}$ ), como podem ser observadas nos valores das variâncias (TABELA 30), bem como nos valores mínimos e máximos das respectivas pressões.

É nítida a superioridade da pressão de propagação da fratura (ou nova ruptura) em relação ao da iniciação da ruptura no maciço. Salienta-se que a superioridade do valor médio da pressão de paralisação em relação ao da injeção deve-se ao critério utilizado no ensaio, que foi encerrado quando a pressão atingisse $70 \%$ do valor de injeção.

Para comparar os valores médios obtidos dessas pressões, foi necessário recorrer às análises estatísticas, tendo em vista os diferentes conjuntos de valores que definiram as médias calculadas. Para isso, foi aplicado o teste - t de duas amostras em par para as médias (APÊNDICE), que verifica a diferença entre duas médias amostrais. Com o objetivo de avaliar as diferenças entre quatro valores médios $\left(\mathrm{P}_{\mathrm{r}}, \mathrm{P}_{\mathrm{i}}, \mathrm{P}_{\mathrm{c}}\right.$ e $\left.\mathrm{P}_{\mathrm{p}}\right)$, foi necessário realizar três comparações estatísticas, tomando-se dois valores médios de cada vez. Desta maneira, foram realizadas as seguintes comparações: $\left(\mathrm{P}_{\mathrm{r}} \times \mathrm{P}_{\mathrm{c}}\right)$; $\left(\mathrm{P}_{\mathrm{p}} \times \mathrm{P}_{\mathrm{r}}\right)$ e $\left(\mathrm{P}_{\mathrm{i}} \times \mathrm{P}_{\mathrm{p}}\right)$.

Para aplicação do teste $\mathbf{t}$, foram admitidas as seguintes hipóteses:

1. No teste unicaudal:

- hipótese admitida $\left(\mathrm{H}_{0}\right)$ : a média da primeira amostra $\left(\overline{\mathrm{x}}_{1}\right)$ é igual à média da segunda amostra $\left(\overline{\mathrm{x}}_{2}\right)$, ou seja, $\overline{\mathrm{x}}_{1}=\overline{\mathrm{x}}_{2}$ (indica igualdade entre os valores médios comparados);

- hipótese alternativa $\left(\mathrm{H}_{1}\right)$ : a média da primeira amostra é maior ou menor que a média da segunda amostra, ou seja, $\overline{\mathrm{x}}_{1}>\overline{\mathrm{x}}_{2}$ ou $\overline{\mathrm{x}}_{1}<\overline{\mathrm{x}}_{2}$ (indica inferioridade ou superioridade entre os valores médios comparados). 
onde:

$\overline{\mathrm{x}}_{1}=$ pressão média da primeira amostra;

$\overline{\mathrm{x}}_{2}=$ pressão média da segunda amostra.

A aceitação da hipótese $\mathrm{H}_{0}$ está condicionada ao resultado da comparação entre os valores da estatística t (Stat t) e do t crítico unicaudal, como está exposto no APÊNDICE deste trabalho.

TABELA 30 - Resultados da estatística descritiva das pressões: $\mathrm{P}_{\mathrm{r}} ; \mathrm{P}_{\mathrm{i}}$; $\mathrm{P}_{\mathrm{c} 1}$; e $\mathrm{P}_{\mathrm{p}}$. $(\mathrm{MPa})$

\begin{tabular}{lr}
\hline \multicolumn{2}{c}{ Pressão de iniciação da ruptura (Pr) } \\
\hline Média & 1,80 \\
Erro padrão & 0,238 \\
Mediana & 1,05 \\
Moda & 1,0 \\
Desvio padrão & 1,65 \\
Variância da amostra & 2,711 \\
Curtose & 3,85 \\
Assimetria & 1,936 \\
Intervalo & 7,6 \\
Mínimo & 0,4 \\
Máximo & 8 \\
Soma & 86,4 \\
Contagem & 48 \\
Nível de confiança (95,0\%) & 0,478 \\
\hline
\end{tabular}

\begin{tabular}{lr}
\hline \multicolumn{2}{c|}{$\begin{array}{c}\text { Pressão de nova ruptura ou de } \\
\text { propagação (Pc) }\end{array}$} \\
\hline Média & 3,80 \\
Erro padrão & 0,257 \\
Mediana & 3,65 \\
Moda & 4,0 \\
Desvio padrão & 1,78 \\
Variância da amostra & 3,180 \\
Curtose & $-0,37$ \\
Assimetria & 0,741 \\
Intervalo & 6,5 \\
Mínimo & 1,5 \\
Máximo & 8,0 \\
Soma & 182,6 \\
Contagem & 48 \\
Nível de confiança (95,0\%) & 0,518 \\
\hline
\end{tabular}

\begin{tabular}{lr}
\hline \multicolumn{2}{c}{ Pressão de injeção (Pi) } \\
Média & 0,57 \\
Erro padrão & 0,042 \\
Mediana & 0,55 \\
Moda & 0,2 \\
Desvio padrão & 0,29 \\
Variância da amostra & 0,086 \\
Curtose & $-1,09$ \\
Assimetria & 0,307 \\
Intervalo & 1,0 \\
Mínimo & 0,2 \\
Máximo & 1,2 \\
Soma & 27,2 \\
Contagem & 48 \\
Nível de confiança (95,0\%) & 0,085 \\
\hline
\end{tabular}

\begin{tabular}{lr}
\hline \multicolumn{2}{c}{ Pressão de paralisação (Pp) } \\
\hline Média & 0,97 \\
Erro padrão & 0,178 \\
Mediana & 0,60 \\
Moda & 0,8 \\
Desvio padrão & 1,24 \\
Variância da amostra & 1,528 \\
Curtose & 11,01 \\
Assimetria & 3,278 \\
Intervalo & 5,8 \\
Mínimo & 0,2 \\
Máximo & 6,0 \\
Soma & 46,5 \\
Contagem & 48 \\
Nível de confiança (95,0\%) & 0,359 \\
\hline
\end{tabular}


Os resultados estatísticos obtidos nas três comparações efetuadas são exibidos na TABELA 31. É importante frisar que esses resultados foram conseguidos ao comparar as médias contidas na coluna da esquerda da referida tabela com as médias da coluna da direita. Assim, na primeira comparação os cálculos efetuados foram entre $P_{r}$ e $P_{c}$, na segunda, entre $\mathrm{P}_{\mathrm{p}}$ e $\mathrm{P}_{\mathrm{r}}$ e na terceira, entre $\mathrm{P}_{\mathrm{i}}$ e $\mathrm{P}_{\mathrm{p}}$.

Ao analisar os resultados do teste t (TABELA 31) da primeira comparação efetuada, pode-se notar que o valor da estatística $\mathbf{t}$ (Stat $\mathbf{t}=-6,786$ ) é menor que o valor do $\mathbf{t}$ crítico unicaudal $(-1,299)$. Por esse motivo, a estatística evidenciou a necessidade de rejeitar a hipótese $\mathrm{H}_{0}$ e, conseqüentemente, indicou pela aceitação da hipótese $\mathrm{H}_{1}$. Desta maneira, conclui-se que a média da pressão de iniciação da ruptura é menor que a média da pressão de propagação $\left(\mathrm{P}_{\mathrm{r}}<\mathrm{P}_{\mathrm{c}}\right)$. A probabilidade de correr inversões nesse resultado é muito baixa, 8,61x $10^{-9} \%$ (TABELA 31). Nesta tabela, pode-se observar também a correlação de Pearson $(0,29)$, indicando uma associação positiva entre as médias comparadas.

Ao analisar os resultados das outras duas comparações efetuadas (TABELA 31), pode-se concluir que:

- na $2^{\mathrm{a}}$ comparação: a pressão de paralisação $\left(\mathrm{P}_{\mathrm{p}}\right)$ é inferior à média da pressão de ruptura $\left(\mathrm{P}_{\mathrm{r}}\right)$;

- na $3{ }^{\text {a }}$ comparação: a pressão de injeção $\left(\mathrm{P}_{\mathrm{i}}\right)$ também é menor que a média da pressão de paralisação $\left(\mathrm{P}_{\mathrm{p}}\right)$.

À semelhança da primeira comparação efetuada, os resultados estatísticos também indicaram baixa probabilidade de inversão entre Stat $\mathbf{t}$ e o $\mathbf{t}$ crítico correspondente.

Portanto, ao final das três comparações efetuadas por meio do teste $\mathbf{t}$ para duas amostras em par para médias, os resultados estatísticos mostraram as seguintes evidências: 
- a média da pressão de iniciação da ruptura do maciço $\left(\mathrm{P}_{\mathrm{r}}=1,80 \mathrm{MPa}\right)$, obtida na construção da cortina de vedação, foi menor que a média da pressão de propagação da fratura (ou da abertura de outra fratura) $\left(\mathrm{P}_{\mathrm{c}}=3,80 \mathrm{MPa}\right)$;

- o valor médio da pressão de paralisação $\left(\mathrm{P}_{\mathrm{p}}=0,97 \mathrm{MPa}\right)$ obtido no teste do fraturamento foi menor que o valor médio da ruptura $\left(\mathrm{P}_{\mathrm{r}}=1,80 \mathrm{MPa}\right)$;

- a média da pressão de injeção $\left(\mathrm{P}_{\mathrm{i}}=0,57 \mathrm{MPa}\right)$ da fratura induzida foi menor que a da paralisação $\left(\mathrm{P}_{\mathrm{p}}=0,97 \mathrm{MPa}\right)$.

Tomando-se como verdadeiras esses resultados estatísticos, conclui-se que nos ensaios de fraturamento hidráulico realizados em solo residual de granitóides, a pressão de propagação da fratura hidráulica (3,8 MPa) apresentou valor médio duas vezes maior que a pressão de ruptura (1,8 MPa). Verificou-se também que o valor médio da pressão de injeção (0,57 MPa) é inferior à média da pressão de ruptura.

Para evitar a formação de vazios na fratura hidráulica, foi estabelecido que a injeção seria paralisada quando a pressão aplicada aumentasse. No caso destes ensaios, a pressão média de paralisação (0,97 MPa) ficou cerca de 70\% maior que a pressão de injeção (0,57 MPa).

Os ensaios realizados mostraram ainda a nítida semelhança entre o ciclo de variação da pressão observado durante o ensaio do fraturamento hidráulico em maciço terroso e o ciclo em maciço rochoso. Vale lembrar que, em maciços rochosos, estes ensaios têm sido realizados para determinação das tensões atuantes (HAIMSON, 1980 e 1998). Conforme demonstrado em ISRM (1987), para promover ruptura hidráulica no maciço rochoso em furos de sondagens, é necessário elevar a pressão do fluido a ser injetado, utilizando-se obturador duplo, até que ocorra a fratura induzida. Após a ruptura, a pressão decresce rapidamente e se mantém inalterada durante a injeção do fluido na fratura da rocha, que, preenchida, provoca nova subida da pressão. Ao atingir o valor de reabertura da fratura, a pressão decai e retorna ao mesmo valor da pressão de injeção (FIGURA 6). Esse 
comportamento da pressão foi observado por HAYASHI \& SAKURAY (1989) nos estudos efetuados em modelos matemáticos. O gráfico da FIGURA 65 mostra o comportamento da pressão.

TABELA 31 - Resultados do teste $\mathbf{t}$ (duas amostras em par) para os valores médios das pressões de ruptura da bainha e da segunda ruptura; de injeção e de paralisação; e de paralisação e de ruptura da bainha.

\begin{tabular}{l|r|r}
\hline \multicolumn{1}{c|}{$1^{a}$ comparação } & $\begin{array}{c}\text { Pressão de ruptura } \\
\text { Pr (MPa) }\end{array}$ & $\begin{array}{c}\text { Pressão de propagação } \\
\text { Pc (MPa) }\end{array}$ \\
\hline Média & 1,80 & 3,80 \\
Variância & 2,711 & 3,181 \\
Observações & 48 & 48 \\
Correlação de Pearson & 0,29 & 0 \\
Hipótese da diferença de média $(\Delta)$ & 47 & \\
Grau de Liberdade & $-6,786$ & \\
Stat t & $8,61 \mathrm{E}-09$ & $-1,299$ \\
Probabilidade Stat t $\leq \mathrm{t}$ crítico unicaudal $(\%)$ & & \\
t crítico unicaudal & \\
\hline
\end{tabular}

\begin{tabular}{|c|c|c|}
\hline $2^{a}$ comparação & $\begin{array}{c}\text { Pressão de paralisação } \\
\text { Pp (MPa) }\end{array}$ & $\begin{array}{l}\text { Pressão de ruptura } \\
\text { Pr (MPa) }\end{array}$ \\
\hline Média & 0,97 & 1,80 \\
\hline Variância & 1,528 & 2,711 \\
\hline Observações & 48 & 48 \\
\hline Correlação de Pearson & 0,24 & \\
\hline Hipótese da diferença de média $(\Delta)$ & 0 & \\
\hline Grau de Liberdade & 47 & \\
\hline Stat t & $-3,179$ & \\
\hline Probabilidade Stat $\mathrm{t} \leq \mathrm{t}$ crítico unicaudal (\%) & 0,001 & \\
\hline t crítico unicaudal & $-1,299$ & \\
\hline $3^{a}$ comparação & $\begin{array}{c}\text { Pressão de injeção } \\
\text { Pi (MPa) }\end{array}$ & $\begin{array}{c}\text { Pressão de paralisação } \\
\text { Pp (MPa) } \\
\end{array}$ \\
\hline Média & 0,57 & 0,97 \\
\hline Variância & 0,086 & 1,528 \\
\hline Observações & 48 & 48 \\
\hline Correlação de Pearson & 0,21 & \\
\hline Hipótese da diferença de média $(\Delta)$ & 0 & \\
\hline Grau de Liberdade & 47 & \\
\hline Stat t & $-2,303$ & \\
\hline Probabilidade Stat $\mathrm{t} \leq \mathrm{t}$ crítico unicaudal (\%) & 0,012 & \\
\hline t crítico unicaudal & $-1,299$ & \\
\hline
\end{tabular}

A diferença principal observada entre os ciclos da pressão no maciço rochoso e terroso está nos valores das pressões, pois tratam-se de maciços com diferentes resistências 
mecânicas. Além disso, no maciço terroso, a pressão de propagação da fratura é superior à pressão inicial de ruptura. Acredita-se que tal fato se deve às maiores perdas de carga ocorridas no processo de injeção em maciço terroso, provocadas pelas válvulas-manchete, bainhas e a própria calda de solo-cimento. Além disso, no caso dos ensaios hidráulicos em maciços rochosos, emprega-se a água como fluido de injeção, que apresenta menor perda de carga em relação às caldas de solo-cimento.

A confirmação desse comportamento, em ciclo, da pressão durante o processo de tratamento do maciço terroso com caldas de solo-cimento permite sugerir que o encerramento da injeção deve ocorrer na fase de ascensão da pressão, após ter atingido, no mínimo, o volume de calda exigido em projeto. Com efeito, nesta sugestão, fica subentendido que a ascensão da pressão aplicada é devido à ocupação total da fratura pela calda de solo-cimento injetada.

Após a conclusão das injeções na cortina de vedação, foram escavados quatro poços com $11 \mathrm{~m}$ de profundidade, a jusante dessa cortina (FIGURA 39). Nas paredes desses poços, foram realizados levantamentos das fraturas hidráulicas preenchidas com caldas endurecidas de solo-cimento. Outro levantamento foi efetuado nas paredes de uma trincheira, escavada paralelamente aos 5 furos injetados no campo de provas. Nestes levantamentos, foram observadas as seguintes ocorrências:

- Poço D1 (margem direita): 3 fraturas verticais e 1 subvertical ( $70^{\circ}$ de mergulho);

- Poço D2 (margem direita): 1 fratura vertical e 3 suborizontais;

- Poço E1 (margem esquerda): 1 fratura subvertical (70 de mergulho) e 1 inclinada ( $40^{\circ}$ de mergulho);

- Poço E2 (margem esquerda): 4 fraturas verticais e 1 horizontal;

- Trincheira escavada no campo de provas: 9 fraturas verticais e 1 suborizontal.

Das 25 fraturas identificadas nos poços e trincheira, 19 (ou 76\%) estavam posicionadas na vertical a subvertical (entre $90^{\circ}$ e $70^{\circ}$ ), 5 (20\%) inclinadas na suborizontais 
(até $30^{\circ}$ ) e $1(4 \%)$ inclinada (entre $30^{\circ}$ e $70^{\circ}$ ). Tais observações confirmam os resultados alcançados por REED \& DUSSEAULT (1997), em especial quanto à predominância das fraturas hidráulicas verticais. A FIGURA 66 mostra duas nítidas fraturas hidráulicas quase verticais e uma praticamente horizontal que foram encontradas no poço E2. A foto exibida na FIGURA 67 foi obtida na trincheira do campo de provas, onde pode-se observar uma fratura vertical ao longo da bainha, contendo pequenos vazios formados na calda endurecida (pontos escuros), atribuídos à falha na injeção. Essa falha provavelmente é conseqüência do critério utilizado (300 $\ell$ por válvula) na injeção que não foi o de paralisar na ascensão da pressão aplicada.

Vale salientar que as três fraturas suborizontais encontradas no poço D2 provavelmente foram condicionadas pela proximidade do topo rochoso alterado e núcleos rígidos de rocha alterada que ocorrem no local.

As espessuras medidas das caldas endurecidas, nos poços e na trincheira, situaram-se em torno de $2 \mathrm{~cm}$ e confirmaram os resultados dos estudos realizados por BARRADAS (1985) em Balbina. Tal fato fortalece o uso dos conceitos desenvolvidos pelo autor para o dimensionamento preliminar do projeto de tratamento com injeção de calda de solo-cimento.

No poço E2, foi encontrada uma fratura hidráulica preenchida com calda endurecida de solo-cimento que interceptou duas fraturas geológicas, próximo da cota 644 m, atravessando-as sem que sofresse interferência (FIGURA 68). Esta observação mostra que as estruturas geológicas reliquiares nem sempre constituem em condicionantes ao processo do fraturamento hidráulico. Ao contrário, nos ensaios de fraturamento hidráulico em maciços rochosos, as fraturas naturais constituem-se em flagrantes planos de fraqueza.

Não foi possível realizar observações a respeito do alcance das caldas e das relações entre fraturas induzidas de diferentes furos em variados níveis do terreno, ainda que foram empregados corantes nas caldas injetadas. Embora de cores bastante diferentes, os 
corantes utilizados, de uso comercial na construção civil, apresentaram descoloração após o endurecimento da calda. Por esse motivo, foi difícil distinguir as caldas injetadas, bem como observar suas relações. Pretendia-se ainda por meio do uso de corantes, determinar o alcance da calda e relacioná-lo com a pressão aplicada e com o volume injetado, visando estabelecer critérios executivos de injeção.

\subsection{Consolidação de fundações}

Em geral, os trabalhos de injeção para consolidação de fundações são realizados sem obedecer a um critério seqüencial de ordem de injeção (primária, secundária, terciária, etc.), diferenciando-se das atividades para construção de cortina de vedação.

No tratamento de consolidação da Usina de Rasgão, manteve-se este procedimento, tendo sido executados 347 furos com profundidades variáveis entre 7 e 26 m. Neles, foram instaladas 1.032 válvulas-manchete, sendo que 78 válvulas (8\% do total) apresentaram problemas. A grande maioria (70 válvulas) teve problemas relacionados às características geológico-geotécnicas locais, e as outras 8 válvulas, à presença de concreto da fundação das estruturas civis, conforme já descrito anteriormente. Portanto, a análise estatística efetuada está fundamentada nos registros de 954 válvulas-manchete injetadas. Ressalta-se que no ANEXO B existem 1.399 registros, dos quais 367 não contêm valores de pressões, tendo sido utilizados apenas para indicar a posição da fundação de concreto, final dos furos e eventuais matacões.

Os resultados da estatística descritiva das pressões de ruptura das bainhas e de injeção do tratamento para consolidação das fundações das estruturas da usina foram apresentados no ANEXO H. Ressalta-se que o intervalo de profundidade (2 m) foi escolhido em função da pequena profundidade (7 m) de grande maioria dos furos de injeção. 


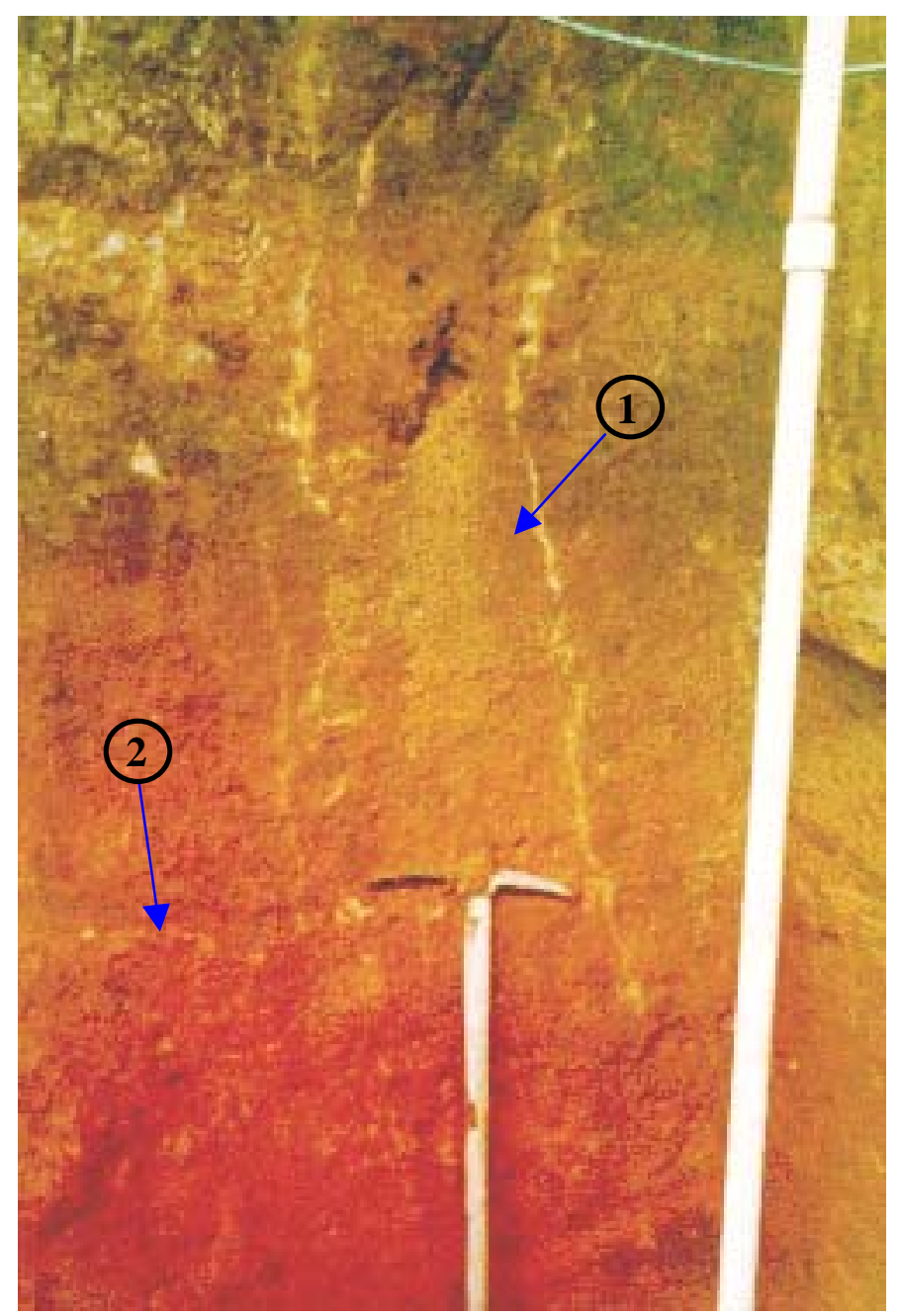

FIGURA 66 -Fraturas hidráulicas na vertical e uma na horizontal, preenchidas com calda de solo-cimento endurecida, observadas no poço E2.

Em todos os intervalos de profundidades analisados, foi verificado que os valores médios da pressão de iniciação da ruptura do maciço são substancialmente superiores aos da injeção. As variações encontradas nos valores médios foram, respectivamente, para a de ruptura e injeção de 2,26 a 2,81 MPa e 0,46 a 1,13 MPa. Os gráficos da FIGURA 69 mostram a variação dos valores médios das pressões nos diferentes intervalos de profundidades considerados. 


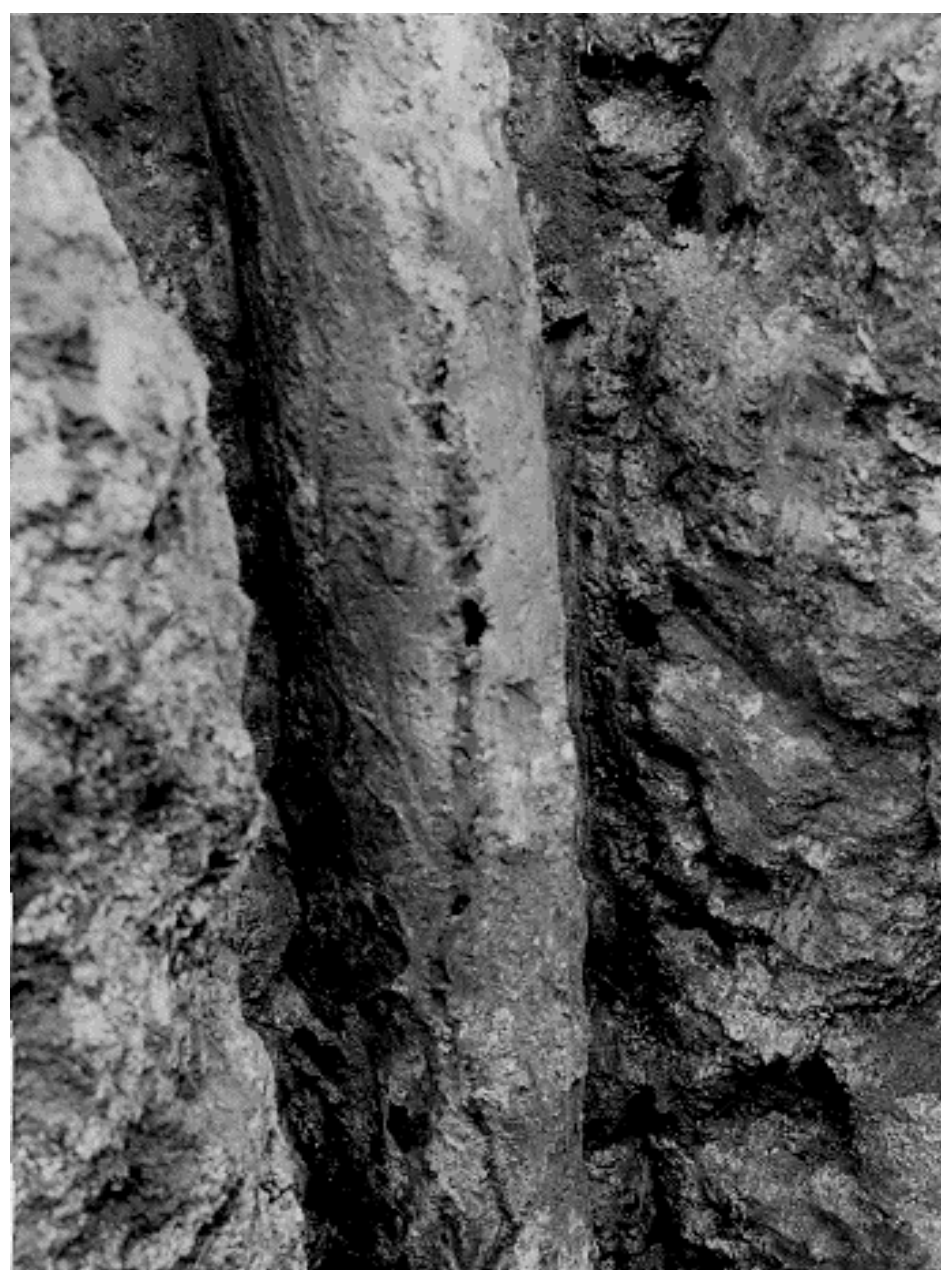

FIGURA 67 - Imagem extraída da bainha de um furo no campo de prova. Observar a calda endurecida na vertical contendo pontos escuros (vazios).

A FIGURA 69 mostra ainda a correlação positiva entre as variações ocorridas nas pressões de ruptura e de injeção nos diferentes intervalos de profundidades, como foi verificado no caso da cortina de vedação. Mais uma vez acredita-se que tal correlação esteja associada à resistência mecânica do meio (maciço, válvula e bainha).

Com efeito, os resultados estatísticos não mostraram evidências de ocorrência de crescimento nos valores médios das pressões de ruptura ou de injeção, à medida que se aumentava as profundidades das válvulas-manchete. Contrariamente, os gráficos da FIGURA 69 e os resultados obtidos indicaram certa tendência dos valores médios se aproximarem de um valor constante. 


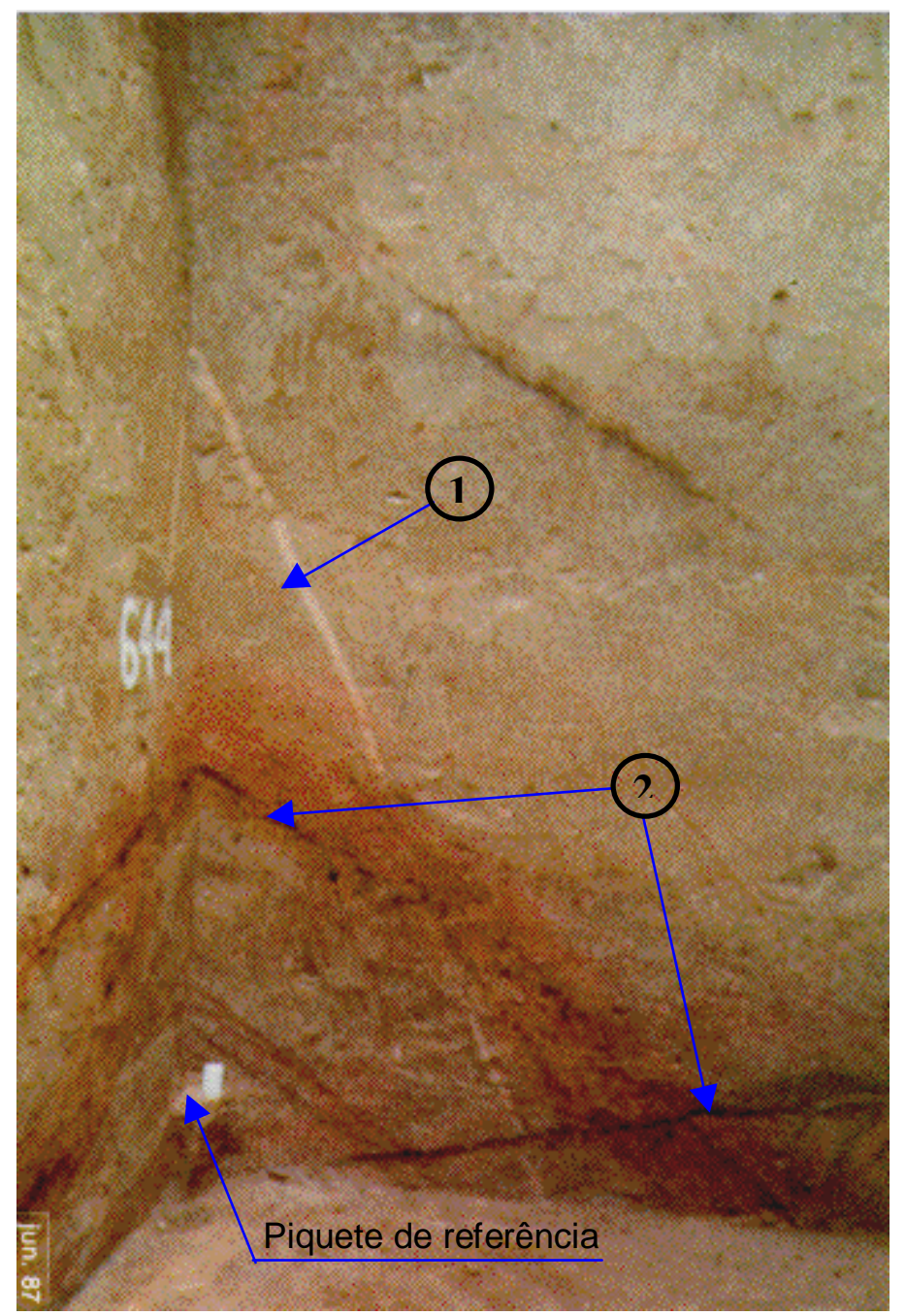

FIGURA 68 - Intersecção da calda de solo-cimento (cor clara) com duas fraturas reliquiares do maciço (cor escura), sem que ocorresse interferência, observada no poço E2.

Nos trabalhos realizados na unidade industrial da Cooperativa Central de Laticínios do Estado de São Paulo, onde foram instaladas 1.983 válvulas-manchete em profundidades que variaram de 1 a $6 \mathrm{~m}$, as médias da pressão de iniciação da ruptura do maciço também apresentaram valores muito superiores da pressão de injeção, como mostra a TABELA 32. Os valores médios da pressão de ruptura ficaram entre 3,0 e 3,5 MPa e com $70 \%$ dos valores compreendidos entre 1,0 e 5,5 MPa, ao passo que o valor médio da injeção situou-se próximo de 1,0 MPa e com 70\% dos valores entre 0,2 e 1,7 MPa. 


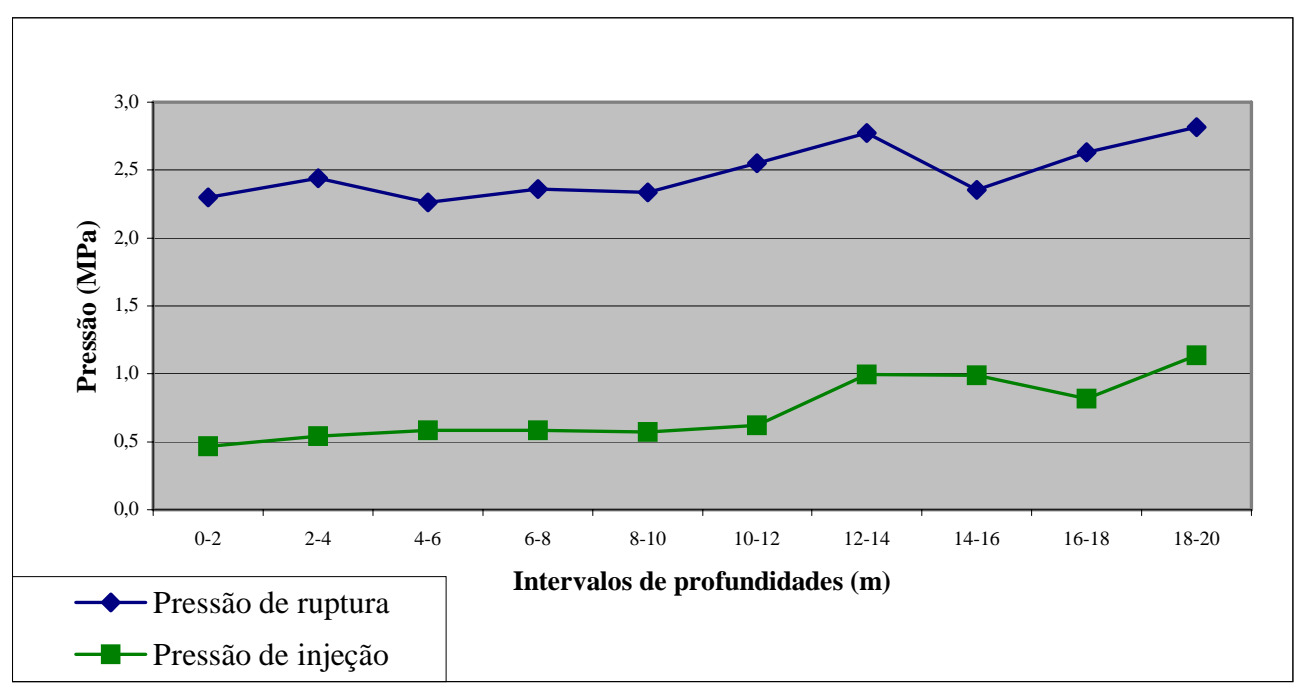

FIGURA 69 - Variação dos valores médios das pressões de iniciação da ruptura do maciço e de injeção no tratamento de consolidação da Usina de Rasgão.

Como no caso da Usina de Rasgão, as médias das pressões de iniciação da ruptura do maciço são mais elevadas que da injeção (TABELA 32), nos diferentes intervalos de profundidades. Nesta tabela, os resultados revelaram que as médias das pressões cresceram do primeiro intervalo para o segundo e decaíram ao passar para o terceiro intervalo de profundidade, exceto com a pressão de injeção na região do laboratório. Revelaram ainda que as médias das pressões apresentaram variações, de acordo com o local tratado. Os valores mais elevados foram encontrados nas fundações do laboratório, e os menores, na região da caixa d’água.

\subsection{Eficiência do tratamento}

A principal e tradicional técnica utilizada para avaliação da eficiência do tratamento de maciço por injeção é o ensaio de permeabilidade. Trata-se de um ensaio de execução simples, realizado em furos de sondagens, que fornece o valor do coeficiente de permeabilidade in situ do maciço. 
Ensaios de permeabilidade in situ foram realizados durante a campanha de investigação do maciço terroso de fundação da usina de Rasgão, bem como após a construção da cortina de vedação com injeção de solo-cimento. A comparação efetuada entre esses resultados, por meio da estatística, mostrou que ocorreu redução na percolação de água pelo maciço após as injeções. Os resultados obtidos pela estatística descritiva dos coeficientes de permeabilidade são mostrados na TABELA 33.

Essa técnica para avaliar a eficiência por meio do ensaio de permeabilidade em furos de sondagens também foi aplicada nos trabalhos da Barragem de Balbina. Os resultados finais indicaram que houve redução na percolação de água pelo maciço de fundação. Nesta obra, antes da intervenção com as injeções de calda de solo-cimento, os maiores coeficientes registrados superaram a $10^{-3} \mathrm{~cm} / \mathrm{s}$ (30\% dos ensaios). Foram encontrados apenas em $6 \%$ dos ensaios realizados coeficientes menores que $10^{-4} \mathrm{~cm} / \mathrm{s}$.

Após o tratamento, os ensaios revelaram que o coeficiente de permeabilidade decresceu para valores de $10^{-4} \mathrm{~cm} / \mathrm{s}$ (50\% dos resultados obtidos), não tendo sido encontrado nenhum caso com valor superior a $10^{-3} \mathrm{~cm} / \mathrm{s}$ (ELETRONORTE, 1984b).

Na TABELA 6, são apresentados os coeficientes de permeabilidade do maciço terroso natural e depois do tratamento, na Usina de Rasgão. A comparação entre os coeficientes de permeabilidade, apresentados nesta tabela, foi feita por meio da estatística. Para isso, foi aplicada a técnica do teste t para duas amostras, presumindo variâncias diferentes. Os resultados do teste são apresentados na TABELA 34.

Para aplicar o mencionado teste, foram estabelecidas as seguintes hipóteses:

1. No teste unicaudal:

- hipótese admitida $\left(\mathrm{H}_{0}\right)$ : os coeficientes médios da permeabilidade do terreno, antes e depois da construção da cortina de vedação, são iguais

$$
\left(\overline{\mathrm{x}}_{1}=\overline{\mathrm{x}}_{2}\right)
$$


- hipótese alternativa $\left(\mathrm{H}_{1}\right)$ : o coeficiente médio da permeabilidade do terreno antes da construção da cortina de vedação é maior ou menor que depois da construção da cortina $\left(\overline{\mathrm{x}}_{1}>\overline{\mathrm{x}}_{2}\right.$ ou $\left.\overline{\mathrm{x}}_{1}<\overline{\mathrm{x}}_{2}\right)$.

onde:

$\overline{\mathrm{x}}_{1}=$ coeficiente médio da permeabilidade do terreno natural;

$\overline{\mathrm{x}}_{2}$ = coeficiente médio da permeabilidade do terreno depois da construção da cortina de vedação.

Na TABELA 34, pode-se notar que o valor da estatística $\mathbf{t}$ (Stat $\mathbf{t}=7,159)$ é maior do que o valor do $\mathbf{t}$ crítico (unicaudal $=1,637$ ). Por esse motivo, a estatística (ver APÊNDICE) indicou que há indícios para rejeitar a hipótese $\mathrm{H}_{0}$; portanto, o coeficiente médio de permeabilidade antes do tratamento por injeção $\left(\bar{x}_{1}\right)$ é maior que o coeficiente depois da injeção $\left(\overline{\mathrm{x}}_{2}\right)$.

Com efeito, observa-se ainda que a probabilidade de ocorrer inversão nos resultados obtidos é muito baixa (0,002\%). 
TABELA 32 - Valores médios das pressões do tratamento da Cooperativa (PROGECONSULT, 1997).

\begin{tabular}{|c|c|c|c|c|c|c|c|c|c|c|}
\hline \multicolumn{2}{|l|}{ Local } & \multicolumn{3}{|c|}{ Laboratório } & \multicolumn{3}{|c|}{ Caixa d'água } & \multicolumn{3}{|c|}{ Casa das caldeiras } \\
\hline \multicolumn{2}{|c|}{ Profundidade em trechos (m) } & $0,0-2,0$ & $2,0-4,0$ & $4,0-6,0$ & $0,0-2,0$ & $2,0-4,0$ & $4,0-6,0$ & $0,0-2,0$ & $2,0-4,0$ & $4,0-6,0$ \\
\hline \multicolumn{2}{|c|}{ Número de válvulas } & 250 & 459 & 457 & 100 & 135 & 127 & 110 & 182 & 163 \\
\hline \multirow{4}{*}{$\begin{array}{l}\text { Pressão de iniciação } \\
\text { da ruptura Pr (MPa) }\end{array}$} & Média & $\overline{3,05}$ & 3,48 & $\overline{3,16}$ & 1,73 & 2,43 & 1,69 & 2,41 & 2,57 & 1,28 \\
\hline & Desvio padrão & 2,02 & 2,03 & 2,00 & 1,79 & 2,19 & 1,99 & 2,08 & 2,27 & 1,72 \\
\hline & Máxima & 7,30 & 7,30 & 7,80 & 7,20 & 7,20 & 7,00 & 7,30 & 7,20 & 7,00 \\
\hline & Mínima & 0,00 & 0,00 & 0,00 & 0,00 & 0,00 & 0,00 & 0,00 & 0,00 & 0,00 \\
\hline \multirow{4}{*}{$\begin{array}{l}\text { Pressão de injeção Pi } \\
(\mathrm{MPa})\end{array}$} & Média & 0,95 & 0,98 & 1,01 & 0,37 & 0,50 & 0,26 & 0,64 & 0,87 & 0,83 \\
\hline & Desvio padrão & 0,76 & 0,74 & 0,72 & 0,50 & 0,61 & 0,33 & 0,55 & 0,59 & 0,54 \\
\hline & Máxima & 3,00 & 4,00 & 3,40 & 2,00 & 2,30 & 1,60 & 2,60 & 3,00 & 2,30 \\
\hline & Mínima & 0,00 & 0,00 & 0,00 & 0,00 & 0,00 & 0,00 & 0,00 & 0,00 & 0,00 \\
\hline
\end{tabular}


TABELA 33 - Valores médios do coeficiente de permeabilidade do maciço natural e depois da construção da cortina de vedação na Usina de Rasgão.

\begin{tabular}{c|c|c}
\hline Estatística & $\begin{array}{c}\text { Coeficiente de } \\
\text { permeabilidade do maciço } \\
\text { natural }\end{array}$ & $\begin{array}{c}\text { Coeficiente de } \\
\text { permeabilidade depois do } \\
\text { tratamento }\end{array}$ \\
\hline Permeabilidade média $(\mathrm{cm} / \mathrm{s})$ & $2,9 \times 10^{-4}$ & $5,61 \times 10^{-5}$ \\
\hline Desvio padrão $(\mathrm{cm} / \mathrm{s})$ & $7,02 \times 10^{-4}$ & $7,55 \times 10^{-5}$ \\
\hline Permeabilidade mínima $(\mathrm{cm} / \mathrm{s})$ & $1,1 \times 10^{-5}$ & $1,9 \times 10^{-6}$ \\
\hline Permeabilidade máxima $(\mathrm{cm} / \mathrm{s})$ & $4,4 \times 10^{-3}$ & $4,1 \times 10^{-4}$ \\
\hline
\end{tabular}

TABELA 34 - Comparação efetuada entre os coeficientes de permeabilidade (antes e depois da injeção) por meio do teste $t$ para duas amostras, presumindo variâncias diferentes.

\begin{tabular}{l|r|r}
\hline \multicolumn{1}{c|}{ Estatística } & \multicolumn{1}{c}{ Antes } & \multicolumn{1}{c}{ Depois } \\
\hline Média (cm/s) & $1,29 \times 10^{-4}$ & $2,1 \times 10^{-5}$ \\
\hline Variância (cm/s) & $8,6 \times 10^{-10}$ & $9,98 \times 10^{-11}$ \\
\hline Observações & 4 & 8 \\
\hline Hipótese da diferença de médias & 0 & \\
\hline Grau de Liberdade & 3 & \\
\hline Stat t & 7,159 & \\
\hline Probabilidade Stat t $\leq \mathrm{t}$ crítico unicaudal $(\%)$ & 0,002 & \\
\hline t crítico unicaudal & 1,637 & \\
\hline
\end{tabular}

\subsection{Ensaios no campo de prova}

A injeção de solo-cimento nos maciços tem como resultado o aumento de sua resistência e/ou a diminuição da permeabilidade, que é conseguido através do preenchimento dos espaços vazios existentes ou provocados, como as fraturas naturais ou abertas pelo processo hidráulico. A introdução das caldas nestes vazios traz efeitos diretos na propagação das ondas sísmicas, bem como na percolação da água pelo maciço.

A associação entre as características geológicas do terreno natural e a velocidade de propagação das ondas sísmicas foi obtida por diversos autores, destacando-se 
o trabalho de TURK et al. (1987), que realizaram ensaios geofísicos para avaliar a eficiência de tratamento por injeção em maciços rochosos. Uma das técnicas utilizadas para obter a velocidade das ondas sísmicas é o método crosshole, que tem sido empregado para determinação dos módulos elásticos-dinâmicos de maciços (DOURADO, 1984). Este autor realizou comparações entre coeficientes dinâmicos e estáticos (Poisson, Young e compressibilidade) e verificou que, além dos primeiros serem maiores, as diferenças aumentavam em materiais com menores valores de módulo de elasticidade.

Esses fundamentos teóricos permitiram que fossem realizados ensaios crosshole, em um campo de prova localizado nas proximidades da área tratada na Usina de Rasgão, com objetivo de caracterizar o terreno antes e depois da injeção de solo-cimento. Como se tratava de um estudo ainda não efetuado no Brasil, procurou-se obter o maior número de informações dos ensaios executados, através de:

- execução de sondagens a percussão;

- determinações granulométricas da camada do solo residual de granitóides que sofreu injeção;

- utilização de corantes nas caldas para verificar relações entre fases de injeção;

- ensaios em corpos-de-prova das caldas endurecidas;

- determinações das velocidades sísmicas antes e depois do tratamento com injeção de solo-cimento;

- escavação de uma trincheira ao longo da linha de injeção para avaliação visual do tratamento.

\subsubsection{Aspectos gerais do terreno e do tratamento realizado}

O campo de prova dos ensaios geofísicos situa-se a cerca de $75 \mathrm{~m}$ da cortina de vedação (FIGURA 70). Levantamentos efetuados com sondagens mecânicas mostraram que o terreno é constituído por solo residual de granitóides, como já descrito no item 5.5.3.1. 
Após o primeiro levantamento geofísico, realizado em terreno natural, foram iniciadas as injeções de solo-cimento em cinco furos, dispostos ao longo da mediatriz maior do campo de prova (FIGURA 42). As injeções foram executadas por meio de válvulasmanchete instaladas a cada metro nos tubos de PVC, como na construção da cortina e vedação e consolidação das fundações da Usina de Rasgão. As caldas empregadas para a confecção das bainhas e injeção foram as mesmas utilizadas no tratamento da usina. Aqui também foi adotado o critério de $300 \ell$ de calda por válvula como limite para paralisação da injeção, exceto na válvula situada nas proximidades da superfície do terreno, onde a injeção foi encerrada com o extravasamento da calda.

Os corpos-de-prova das caldas endurecidas submetidas aos ensaios de laboratório apresentaram valor médio de resistência à compressão simples de 0,82 MPa aos 28 dias de idade, com desvio padrão de 0,27 MPa e valores máximo de 1,0 MPa e mínimo de 0,4 MPa.

A TABELA 35 apresenta os valores médios das pressões de iniciação da ruptura do maciço e da injeção, reunidos em intervalos de profundidades de $2 \mathrm{~m}$. Nota-se que os valores médios obtidos das pressões situaram-se acima das médias obtidas na linha terciária da cortina de vedação (ver tabelas contidas no item 6.1.2). 


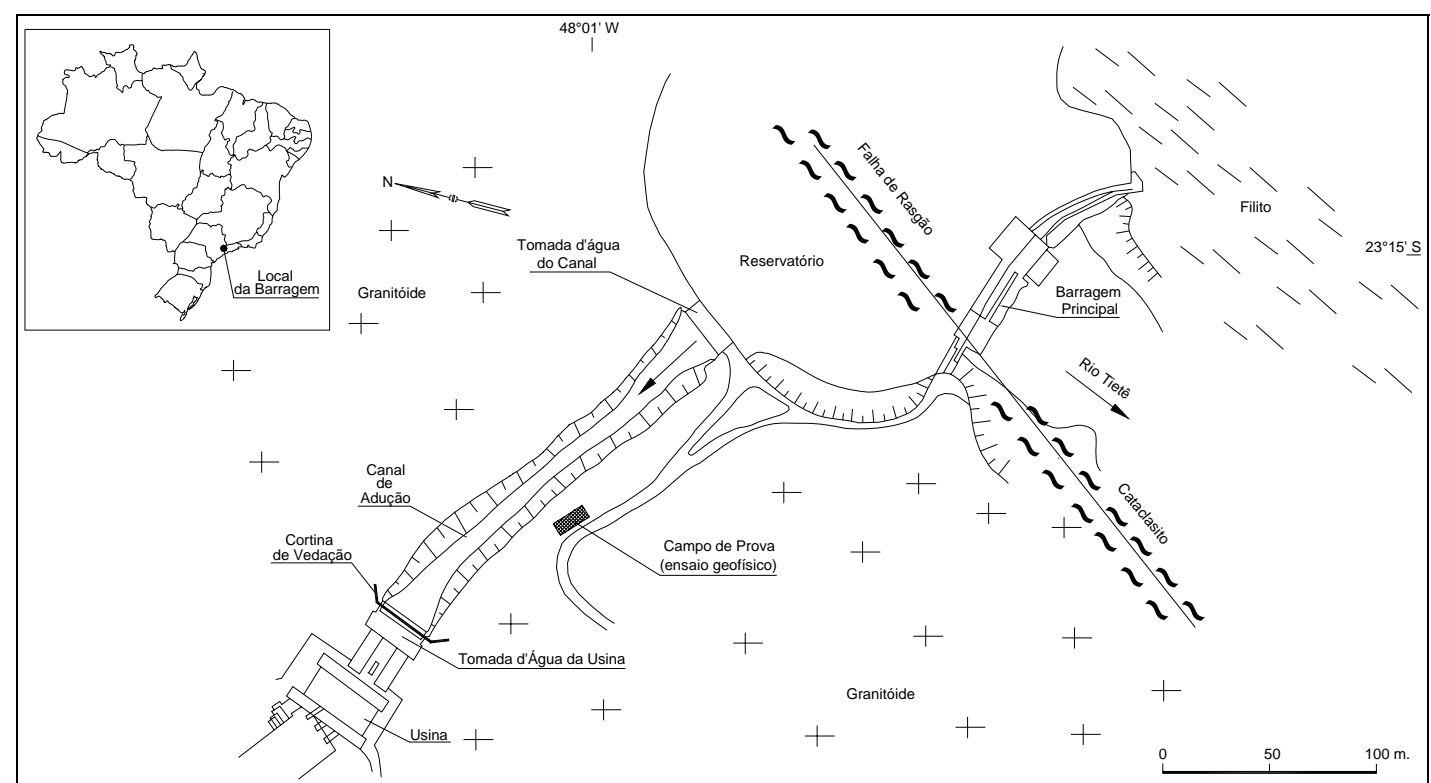

FIGURA 70 - Planta geral da área da Usina de Rasgão com esboço geológico.

TABELA 35 - Médias das pressões de iniciação da ruptura e de injeção, obtidas no tratamento realizado no campo de prova, Usina de Rasgão.

\begin{tabular}{c|l|c|c|c|c}
\hline \multicolumn{2}{c}{ Estatística } & \multicolumn{4}{c}{ Profundidades em cota (m) } \\
\cline { 3 - 6 } \multicolumn{2}{c}{$\begin{array}{c}\text { Pressão de iniciação } \\
\text { da ruptura (MPa) }\end{array}$} & G73 a 671 & $\mathbf{6 7 1}$ a 669 & $\mathbf{6 6 9}$ a 667 & $\mathbf{6 6 7}$ a 665 \\
\cline { 2 - 6 } & Desvio padrão & 2,15 & 1,22 & 0,86 & 1,52 \\
\cline { 2 - 6 } & Máxima & 7,00 & 5,00 & 5,00 & 4,50 \\
\cline { 2 - 6 } & Mínima & 1,00 & 1,50 & 2,50 & 1,00 \\
\hline \multirow{3}{*}{$\begin{array}{c}\text { Pressão de injeção } \\
(\mathrm{MPa})\end{array}$} & Média & 0,92 & 1,16 & 1,09 & 0,96 \\
\cline { 2 - 6 } & Desvio padrão & 0,28 & 0,46 & 0,50 & 0,18 \\
\cline { 2 - 6 } & Máxima & 1,10 & 2,00 & 1,90 & 1,20 \\
\cline { 2 - 6 } & Mínima & 0,20 & 0,20 & 0,20 & 0,80 \\
\hline
\end{tabular}

\subsubsection{Ensaios crosshole}

Antes de execução dos furos no campo de prova, foram realizados testes geofísicos preliminares do tipo crosshole no terreno natural, para que fosse avaliada a qualidade técnica dos resultados obtidos, bem como para determinar a melhor distância entre os furos dos ensaios geofísicos (IPT, 1989). Ao final dos testes realizados os resultados de 
boa qualidade permitiram dar prosseguimento ao programa do levantamento geofísico. Indicaram também que os furos para medidas das velocidades sísmicas deveriam situar-se entre $2 \mathrm{~m}$ a, no máximo, $6 \mathrm{~m}$, uma vez que o aumento da resistência do solo com a profundidade poderia permitir a chegada antecipada de ondas refratadas em horizontes mais rígidos, induzindo a determinação de velocidades aparentes e, portanto, não reais dos níveis ensaiados (PRADO, 1994).

Os resultados dos levantamentos geofísicos são mostrados nas TABELAS 10, 11 e 12, já apresentados no capítulo 5, item 5.5.3.2.

\subsubsection{Análise estatística dos resultados geofísicos}

Baseada nos resultados apresentados, foi realizada uma análise estatística dos tempos de propagação das ondas sísmicas. Os resultados mostraram que nos três pares de furos ensaiados houve redução nesses tempos, portanto ocorreram aumentos na velocidade de propagação das ondas.

A menor redução no tempo de propagação foi observada no par de furos situados na lateral maior do campo de prova (PAR 3), resultante do ensaio geofísico que não interceptou a cortina injetada.

Para confirmar essas reduções nos tempos de propagação, foi realizado o teste $\mathbf{t}$ de duas amostras em par para as médias, admitindo-se as seguintes hipóteses:

1. No teste unicaudal:

- hipótese admitida $\left(\mathrm{H}_{0}\right)$ : os tempos médios de propagação das ondas sísmicas antes e depois das injeções são iguais $\left(\overline{\mathrm{x}}_{1}=\overline{\mathrm{x}}_{2}\right)$; 
- hipótese alternativa $\left(\mathrm{H}_{1}\right)$ : os tempos médios de propagação das ondas sísmicas antes das injeções é maior ou menor que os tempos médios após o tratamento $\left(\overline{\mathrm{x}}_{1}>\overline{\mathrm{x}}_{2}\right.$ ou $\left.\overline{\mathrm{x}}_{1}<\overline{\mathrm{x}}_{2}\right)$.

onde:

$\overline{\mathrm{x}}_{1}=$ tempo médio de propagação das ondas sísmicas antes das injeções;

$\overline{\mathrm{x}}_{2}=$ tempo médio de propagação das ondas sísmicas após as injeções.

Os resultados obtidos na análise estatística, relativas às propagações das ondas sísmicas primárias (S), são apresentados na TABELA 36, onde pode-se verificar, nos três pares de furos, que a estatística $\mathbf{t}$ (Stat $\mathbf{t}$ ) é maior que os valores de $\mathbf{t}$ crítico unicaudal (ver APÊNDICE). Estes resultados indicam que a hipótese admitida $\mathrm{H}_{0}$ deve ser rejeitada. Desta maneira, a estatística indicou que os tempos de propagação das ondas S antes e depois das injeções não são iguais. Por esse motivo, faz-se necessário optar pela aceitação da hipótese alternativa $\mathrm{H}_{1}$. Desta maneira, conclui-se que os tempos médios medidos antes das injeções no campo de prova foram maiores que às médias medidas depois do tratamento, ou seja, $\overline{\mathrm{x}}_{1}>\overline{\mathrm{x}}_{2}$.

Os gráficos da FIGURA 71 mostram as diferenças dos tempos de propagação das ondas $\mathrm{S}$, nos três pares de furos. Nesta figura, no canto inferior à direita, os gráficos procuram mostrar de maneira comparativa as diferenças observadas nos tempos, nos três pares, onde verifica-se que as maiores disparidades ocorreram no PAR 2, trajeto em que as ondas sísmicas tiveram a oportunidade de percorrer maior distância pela cortina injetada. Por outro lado, a trajetória das ondas que não atravessaram a cortina injetada (PAR 3) foi a que apresentou a menor diferença entre os tempos. 
TABELA 36 - Resultados do teste $\mathrm{t}$ (duas amostras em par) para os valores médios dos tempos de propagação das ondas $S$, antes e depois do tratamento do maciço, no campo de prova.

\begin{tabular}{l|c|c|c|c|c|c}
\hline \multicolumn{1}{c}{ Tempo de propagação das ondas S (ms) } \\
\hline \multirow{2}{*}{ Estatística } & \multicolumn{2}{c|}{ PAR 1 } & \multicolumn{2}{c}{ PAR 2 } & \multicolumn{2}{c}{ PAR 3 } \\
\cline { 2 - 7 } & Antes & Depois & Antes & Depois & Antes & Depois \\
\hline Média & 18,01 & 15,79 & 27,51 & 23,154 & 22,47 & 21,41 \\
\hline Variância & 17,19 & 10,98 & 64,42 & 29,6422 & 17,03 & 17,27 \\
\hline Número de observações & 10 & 10 & 10 & 10 & 10 & 10 \\
\hline Correlação de Pearson & 0,960 & & 0,952 & & 0,982 & \\
\hline Hipótese da diferença de média & 0 & & 0 & & 0 & \\
\hline Grau de liberdade & 9 & & 9 & & 9 & \\
\hline Stat t & 5,258 & & 4,184 & & 4,346 & \\
\hline Probabilidade Stat t $\leq \mathrm{t}$ unicaudal & 0,0002 & & 0,0011 & & 0,0009 & \\
\hline t crítico unicaudal & 1,383 & & 1,383 & & 1,383 & \\
\hline
\end{tabular}

Ressalta-se que a execução do ensaio sísmico no PAR 3 foi idealizada para servir como referência para os outros dois pares. Acreditou-se que os tempos nessa lateral do campo de prova (PAR 3) não se alterariam com as injeções, tendo em vista que as trajetórias das ondas entre os furos EN 4 e EN 3 (FIGURA 42) não interceptariam a linha de furos injetados. Se esse fato fosse efetivado, pretendia-se utilizá-lo como argumento para afirmar que as reduções nos tempos dos pares PAR 1 e PAR 2 estariam diretamente relacionadas com a construção da cortina formada pelos furos injetados EI 5 ao EI 9.

Entretanto, ao realizar a análise estatística, ficou comprovado pelo teste t que também houve redução nos tempos de propagação das ondas no PAR 3. Atribuiu-se para essa redução a construção da cortina injetada que funcionou como uma parede boa condutora de ondas sísmicas, ou seja, um meio rígido com menor quantidade de vazios em relação ao solo natural. As ondas sísmicas, ao partirem da fonte instalada no furo EN 4, percorreram o solo residual de granitóide a uma certa velocidade até atingir a parede condutora. Neste meio, a velocidade sofreu aceleração e ao chegar próximo do furo EI 6 voltaram-se em direção ao geofone instalado no furo EN 3, antecipando-se em relação às ondas que se propagaram diretamente entre os furos EN 4 e EN 3. Outro motivo aventado para as 
reduções nos tempos de propagação, foi a possibilidade de ocorrências de veios de calda endurecida instalados na trajetória dessas ondas.

Para evitar a interferência da cortina, sugere-se, para ensaios semelhantes a serem realizados no futuro, que o ensaio para referência (PAR 3) seja realizado na parte externa do campo de prova e na linha diagonal oposta ao PAR 2.

Na FIGURA 71, pode-se verificar ainda uma tendência de suavização nas curvaturas dos gráficos do PAR 1 e, em especial, do PAR 2, mostrando uma possível regularização do maciço para o ensaio geofísico.

Embora a velocidade das ondas P sofra alterações em função da saturação do terreno, foram realizadas as análises estatísticas dos tempos de propagação dessas ondas. Os resultados da execução do teste $\mathbf{t}$ de duas amostras em par para as médias são apresentados na TABELA 37.

Nessa tabela, os resultados obtidos mostraram a superioridade dos valores da estatística t (Stat t) em relação aos valores do t crítico (unicaudal) para o PAR 1 e PAR 2. Ao adotar a mesma técnica desenvolvida anteriormente, verifica-se que os resultados indicaram a rejeição da hipótese $\mathrm{H}_{0}$, evidenciando que as médias dos tempos medidos antes da injeção foram maiores que as médias obtidas depois do tratamento $\left(\overline{\mathrm{x}}_{1}>\overline{\mathrm{x}}_{2}\right)$.

No PAR 3, o valor da estatística $\mathbf{t}$ (Stat $\mathbf{t}=-1,867$ ) é menor que os do $\mathbf{t}$ crítico (unicaudal $=-1,383$ ), por conseguinte foi também rejeitada a hipótese $H_{0}$. Neste caso, os resultados mostraram que a média dos tempos de propagação das ondas $\mathrm{P}$ antes do tratamento ( $\overline{\mathrm{X}}_{1}=13,92 \mathrm{~ms}$ ) foi menor que a média posterior $\left(\overline{\mathrm{X}}_{2}=14,28 \mathrm{~ms}\right)$.

Desta análise, depreende-se que as ondas P, nos pares PAR 1 e PAR 2, também aumentaram de velocidade depois das injeções, quando as trajetórias dessas ondas interceptaram as linhas de furos injetados. No PAR 3, diferentemente do que ocorreu com as ondas S, a média dos tempos de propagação das ondas P aumentou. Não tendo sido encontrada justificativa técnica para essa ocorrência, no entanto convém lembrar que as 
velocidades das ondas P podem aumentar com o grau de saturação do terreno. Como o tempo decorrido entre os ensaios antes e depois da injeção foi de cerca de 30 dias aventou-se a possibilidade de ter ocorrido alteração na saturação do maciço.

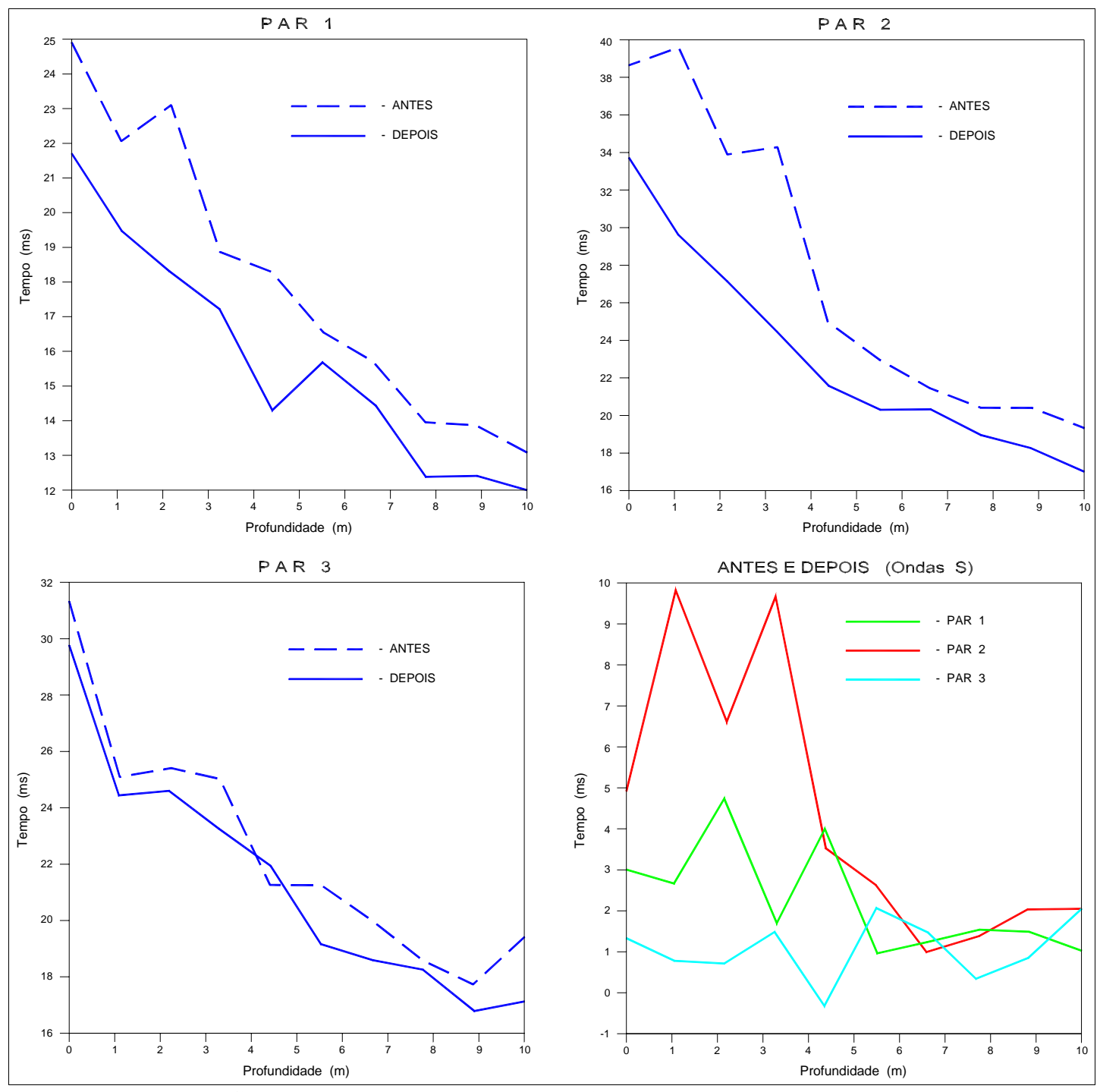

FIGURA 71 - Gráficos dos tempos da onda sísmica S entre os pares PAR 1, PAR 2 e PAR 3 , antes e depois do tratamento com injeção de solo-cimento, no campo de prova da Usina de Rasgão. A figura à direita e abaixo mostra as diferenças nos tempos dos pares. 
Foi realizada uma avaliação qualitativa e visual do tratamento efetuado no campo de prova, através de inspeção direta numa trincheira aberta ao longo da linha de injeção. No levantamento, observou-se que, no local do furo EI 7, uma parte do maciço havia sido preservada, encontrando-se estruturas reliquiares e um núcleo de rocha alterada. Esta situação poderia justificar as pressões de ruptura mais elevadas verificadas no campo de prova (TABELA 35) e, em especial, neste furo. Ressalta-se ainda que a injeção neste furo diferenciou-se das demais pela maior freqüência em extravasar a calda na superfície. Além disso, notou-se que todos os extravasamentos ocorreram na direção aproximada N60W, transversal ao alinhamento dos furos injetados e perpendicular à direção das estruturas geológicas principais. Não foi possível certificar se essa ocorrência estaria associada às fraturas geológicas de tração, como no caso dos maciços rochosos submetidos a tensões naturais.

TABELA 37 - Resultados do teste $\mathrm{t}$ (duas amostras em par) para os valores médios dos tempos de propagação das ondas $P$, antes e depois do tratamento do maciço, no campo de prova.

\begin{tabular}{l|c|c|c|c|c|c}
\hline \multicolumn{1}{c}{ Tempo de propagação das ondas P (ms) } \\
\hline \multirow{2}{*}{ Estatística } & \multicolumn{2}{c}{ PAR 1 } & \multicolumn{2}{c}{ PAR 2 } & \multicolumn{2}{c}{ PAR 3 } \\
\cline { 2 - 7 } & Antes & Depois & Antes & Depois & Antes & Depois \\
\hline Média & 11,34 & 9,72 & 16,28 & 15 & 13,92 & 14,28 \\
\hline Variância & 4,21 & 6,01 & 8,99 & 16,18 & 6,32 & 6,86 \\
\hline Número de observações & 10 & 10 & 10 & 10 & 10 & 10 \\
\hline Correlação de Pearson & 0,882 & & 0,889 & & 0,972 & \\
\hline Hipótese da diferença de média & 0 & & 0 & & 0 & \\
\hline Grau de liberdade & 9 & & 9 & & 9 & \\
\hline Stat t & 4,429 & & 2,096 & & $-1,867$ & \\
\hline Probabilidade Stat $\mathrm{t} \leq \mathrm{t}$ unicaudal & 0,0008 & & 0,0327 & & 0,0473 & \\
\hline t crítico unicaudal & 1,383 & & 1,383 & & $-1,383$ & \\
\hline & & & & & & \\
\hline
\end{tabular}

Observou-se que, tanto nos poços de drenagem como na trincheira, as fraturas induzidas pelo processo hidráulico no maciço terroso apresentavam planos suborizontais e, preferencialmente, subverticais. Isto confirma as observações efetuadas por REED \& DUSSEAULT (1997), nos recentes experimentos realizados em laboratório e em dois 
campos de prova. No caso do maciço terroso, quando o fraturamento induzido ocorre em pequena profundidade, acredita-se que a maior ocorrência de fraturas subverticais possa estar associada, principalmente, às propriedades mecânicas das bainhas, ao formato cilíndrico, além das variações da resistência localizadas no terreno. As possíveis modificações que podem ocorrer no maciço terroso pela introdução de caldas, como as tensões no solo, podem exercer influência no direcionamento das fraturas induzidas. Para que isso seja comprovado, assim como a influência das características físicas da bainha, é necessário realizar estudos de investigação. Por outro lado, as estruturas geológicas reliquiares, presentes no maciço terroso, parecem não interferir no estabelecimento das fraturas induzidas. 


\section{CONCLUSÕES}

As análises efetuadas neste estudo permitiram confirmar parte das hipóteses formuladas no início da pesquisa. A discussão de cada uma delas e os resultados alcançados são a seguir apresentados:

- A análise dos valores médios da pressão de iniciação da ruptura do maciço não confirmou a hipótese do crescimento com a profundidade no terreno, ao desconsiderar os aspectos geológicos do maciço. Todavia, ficou comprovada pela estatística que as médias dessa pressão aumentaram de forma contínua quando as atividades de injeção avançaram, passando da linha primária para a secundária e desta para a terciária.

- Ainda desconsiderando a geologia do maciço, foi verificado o aumento da pressão média de injeção com a profundidade, ao reunir os valores das três linhas de injeção. Ficou comprovada também a superioridade das médias da linha terciária em relação às outras linhas, em todos os intervalos de profundidades considerados. Os estudos efetuados não mostraram evidências estatísticas do crescimento da pressão de injeção na passagem do tratamento da linha primária para a secundária.

- Ao realizar a análise estatística da pressão de iniciação da ruptura do maciço em uma camada do solo residual de granitóide, foi confirmada a ocorrência do crescimento sistemático dessa pressão com a profundidade, na linha primária. Ficou demonstrado também que em todos os intervalos de profundidades, as médias da pressão de ruptura da linha terciária apresentaram valores maiores 
que as das outras linhas. Ainda que as médias calculadas da pressão de injeção apresentassem valores crescentes da linha primária até a terciária, a análise estatística não evidenciou esses aumentos sucessivos.

- Foi confirmado pelo estudo estatístico o aumento da pressão de injeção com a profundidade na camada do solo residual de granitóide (superior), sobretudo na linha primária. As pressões médias da linha terciária apresentaram valores sempre superiores que as das linhas secundária e primária. Por outro lado, a estatística não mostrou evidências do aumento da pressão de injeção da linha primária para a secundária, indicando que os valores médios obtidos nestas linhas não são distintos.

- As maiores taxas de aumentos das pressões de ruptura e de injeção entre as linhas primária e terciária ocorreram próximo da superfície do terreno. Essas taxas apresentaram reduções gradativas à medida que se aprofundou no maciço, confirmando uma das hipóteses levantadas no início dos trabalhos. No entanto, convém ressaltar que, ao desconsiderar a geologia do terreno, esse decaimento na pressão de ruptura não foi comprovado. Nessa situação, a taxa apresentou oscilações.

- O ensaio de fraturamento hidráulico em maciço terroso demonstrou que o ciclo de variação da pressão aplicada assemelha-se ao do ensaio em maciço rochoso. A análise desse ciclo permitiu estabelecer como critério de paralisação da injeção a elevação da pressão aplicada após ter sido injetado o volume mínimo exigido no projeto. O ensaio revelou também a ocorrência predominante das fraturas hidráulicas subverticais seguida das suborizontais, como havia sido relatado por dois pesquisadores (REED \& DUSSEAULT, 1997) em recente estudo realizado no Canadá. 
- A falta de critério para execução seqüencial das injeção de consolidação, nas obras analisadas, não permitiram que fossem efetuadas as análises das pressões à semelhança daquelas realizadas na cortina de vedação.

- A verificação da melhoria do maciço, com a injeção de solo-cimento, a partir da análise estatística das pressões é possível desde que o tratamento seja efetuado em furos dispostos em linhas, preferencialmente, iniciando-se pelas linhas externas e em seguida as internas.

- Os ensaios geofísicos (crosshole) realizados no campo de prova apresentaram resultados de boa qualidade, demonstrando a possibilidade do uso dessa técnica na avaliação da eficiência do tratamento com injeções, em particular por meio da análise da propagação das ondas S. As estatísticas aplicadas no estudo comparativo nos tempos de propagação das ondas sísmicas confirmaram as reduções nos ensaios posteriores à injeção de calda de solo-cimento no maciço. Tal fato evidenciou a melhoria do maciço alcançada com o tratamento. 


\section{SUGESTÕES PARA INJEÇÃO DE SOLO-CIMENTO}

As sugestões aqui apresentadas devem ser vistas como uma proposta inicial, portanto passíveis de alterações e aprimoramentos, e têm como objetivo principal o estabelecimento de procedimentos e normas para execução dos trabalhos de injeção de solocimento em maciço terroso, à semelhança do que foi feito para o tratamento por injeção de calda de cimento em maciço rochoso. Assim, apresentam-se as seguintes sugestões:

1) Adotar o estudo de BARRADAS (1985), para dimensionamento e estimativas do volume mínimo, necessários para elaboração de um projeto de tratamento com injeção.

2) Empregar a seqüência de ensaios apresentados por PITTA (1984) para determinação dos parâmetros reológicos das caldas de solo-cimento.

3) Utilizar nas bainhas, as caldas de solo-cimento que após a cura resultem em materiais com resistência mecânica superior ao do maciço terroso.

4) Executar o tratamento de forma seqüencial e por ordem, mesmo nos trabalhos de consolidação do maciço, dispondo os furos ao longo de linhas.

5) Iniciar as injeções de solo-cimento pelas linhas externas, que delimitam o maciço a ser tratado e servem de obstáculos para as caldas injetadas nos furos das linhas do tratamentos.

6) Paralisar a injeção de calda quando o valor da pressão aplicada superar a média da pressão de injeção, porém depois de ter atingido o volume mínimo estabelecido no projeto. 
7) Realizar ensaios de permeabilidade na cortina de vedação antes e depois do tratamento, complementados com ensaios geofísicos do tipo crosshole.

8) Manter nos tratamentos, ao longo de todo o período dos trabalhos, furos com PVC para execução de ensaios geofísicos antes, durante e depois das injeções.

9) Recorrer à estatística como ferramenta auxiliar para análise das pressões e das velocidades sísmicas. Essas análises sistemáticas com uso de programas de computador permitirão avaliar a eficiência do tratamento em andamento, ainda que de forma preliminar. 


\section{CONSIDERAÇÕES FINAIS}

A técnica de tratamento de maciço terroso com injeção de solo-cimento, ainda que idealizada há algum tempo, não tem sido aplicada sistematicamente no Brasil. Tal fato provavelmente é devido à falta de experiência e à insegurança dos profissionais na eficiência dessa técnica ou até mesmo pelo desconhecimento.

Estudos sobre fraturamento hidráulico em maciço terroso têm sido realizados em laboratórios e campos de prova, por pesquisadores estrangeiros. Acredita-se que a execução deste tipo de ensaio, com monitoramento geotécnico para medida das possíveis alterações provocadas nas tensões do terreno, poderá revelar e até quantificar a melhoria alcançada pelas injeções. É necessário, ainda, verificar prováveis relações das direções das fraturas hidráulicas com o estado atual das tensões geológicas presentes no maciço, bem como dos principais fatores que causam a ocorrência de fraturas suborizontais e subverticais. A predominância das fraturas subverticais favorece a construção de cortinas de vedação, bem como para melhorar o suporte das estruturas nos trabalhos de consolidação.

Os aumentos contínuos das pressões (ruptura e injeção), observados na linha primária na mesma camada de solo residual de granitóide, parecem indicar que existem relações com a resistência mecânica do maciço. As pressões sempre maiores encontradas na linha terciária aparentemente refletem o aumento da resistência do maciço. Esses dois aspectos da injeção em maciço terroso ainda merecem ser estudados em detalhe.

Considerando que a atuação principal de uma cortina de vedação é obstruir ou reduzir a percolação de água pelo maciço, justifica-se a necessidade em realizar estudos laboratoriais para avaliar a durabilidade das caldas endurecidas quando submetidas ao 
regime de trabalho. Tais ensaios devem ser vistos como complemento aos outros ensaios reológicos das caldas, mencionados nesta pesquisa.

A aplicação da geofísica para avaliar a injeção e a eficiência do tratamento por injeção é um recurso que ainda não foi utilizado freqüência no Brasil, provavelmente pela falta de confiança nos métodos geofísicos, ainda desacreditados por diversos motivos. Ao considerar as características dos terrenos brasileiros, onde as espessuras dos solos são elevadas, os métodos geofísicos poderão trazer grandes vantagens, como rapidez no levantamento, acompanhamento sistemático durante o tratamento, baixo custo em relação às tradicionais técnicas para medidas de eficiência, além de tratar-se de uma técnica não destrutiva do terreno ensaiado. Convém ressaltar que os ensaios de permeabilidade são pontuais enquanto que com o ensaio crosshole pode-se obter informações entre dois furos, formando praticamente um plano de observações. A etapa mais onerosa para aplicação desse ensaio é a da perfuração do terreno para instalação dos tubos de PVC. Todavia, o custo desta atividade poderá ser diluído considerando que numa campanha de injeção são realizadas grandes quantidades de perfurações. Ressalta-se que, atualmente, com o avanço da informática e dos equipamentos de geofísica, os ensaios para avaliação da eficiência poderão ser realizados com uso do GPR (Ground Penetrating Radar). 


\section{REFERÊNCIAS BIBLIOGRÁFICAS}

AMERICAN SOCIETY OF CIVIL ENGINEERS - ASCE (1962). Cement grouting. Journal of the Soil Mechanics and Foundation Divison, v.88, n. SM 2, p.49-98.

ANDRADE FILHO, J (1989). Reforço de solos com utilização de tubulões em solos cimento. São Carlos. 190p. Dissertação (Mestrado em Geotecnia) - EESC, USP.

ASSOCIAÇÃO BRASILEIRA DE GEOLOGIA DE ENGENHARIA - ABGE (1975). Ensaios de perda d'água sob pressão: diretrizes. São Paulo: ABGE. (Boletim, 2).

ASSOCIAÇÃO BRASILEIRA DE GEOLOGIA DE ENGENHARIA - ABGE (1981). Ensaios de permeabilidade em solos - orientações para sua execução no campo. São Paulo: ABGE. (Boletim, 4).

ASSOCIAÇÃO BRASILEIRA DE NORMAS TÉCNICAS - ABNT (1983a). Caldas de cimento para injeção: especificação; NBR 7681. Rio de Janeiro.

ASSOCIAÇÃO BRASILEIRA DE NORMAS TÉCNICAS - ABNT (1983b). Caldas de cimento para injeção: determinação dos índices de fluidez. Método de ensaio; NBR 7682. Rio de Janeiro.

ASSOCIAÇÃO BRASILEIRA DE NORMAS TÉCNICAS - ABNT (1983c). Caldas de cimento para injeção: determinação dos índices de exsudação e expansão. Método de ensaio; NBR 7683. Rio de Janeiro.

ASSOCIAÇÃO BRASILEIRA DE NORMAS TÉCNICAS - ABNT (1984d). Caldas de cimento para injeção: determinação da resistência à compressão. Método de ensaio; NBR 7684. Rio de Janeiro.

ASSOCIAÇÃO BRASILEIRA DE NORMAS TÉCNICAS - ABNT (1983e). Caldas de cimento para injeção: determinação da vida útil. Método de ensaio; NBR 7685. Rio de Janeiro.

AZEVEDO, A.A (1993). Análise do fluxo e das injeções nas fundações da barragem de Taquaruçu, rio Paranapanema, SP. São Carlos. 201p. Dissertação (Mestrado) - Escola de Engenharia de São Carlos, Universidade de São Paulo.

BAKER, W. H (1982). Planning and performing structural chemical grouting. In: CONFERENCE ON GROUTING IN GEOTECHNICAL ENGINEERING, New Orleans, 1982. Proceedings... New Orleans: ASCE, AIME, 1982. v.1. tema 7, p.51-539.

BARBEDETE, R.; SABARLY, F (1981). Etudes et utilisations récents des coulis d'injection argileciment. Trad. de Francisco G. Holanda. 12p.

BARBI, A.L.; GOMBOSSY, Z.M.; SIQUEIRA, G.H (1981). Controle de qualidade de calda de cimento para injeção: utilização de traço variável. In: SEMINÁRIO NACIONAL DE GRANDES BARRAGENS, 14., Recife, 1981. Anais... Recife: CBGB. v.1, tema 2, p.207-224.

BARENBLATT, G.I (1962). The mathematical theory of equilibrium cracks in brittle fracture. Advances in Apllied Mechanics. New York: Academic Press, v.3, p.55-129.

BARON, G.; GAY, L.; LE TIRANT, P (1967). Fracturation hydraulique, bases theoriques, études de laboratoire, essais sur camp. In: WORLD PETROL. CONGRESS, 7., 1967. Proceedings... v. 3, p.371-393. 
BARRADAS, S.S (1985). Iniciação e propagação de fraturas induzidas por injeções em solos argilosos com canalículos: aplicação ao tratamento do solo residual de fundação da barragem de terra da usina hidrelétrica de Balbina, AM. Rio de Janeiro. 298p. Dissertação (Mestrado) COPPE, Universidade Federal do Rio de Janeiro.

BERRY, R.M. (1982). Injectie-80 polyacrylamide grout. In: CONFERENCE ON GROUTING IN GEOTECHNICAL ENGINEERING. New Orleans, 1982. Proceedings... New Orleans: ASCE, AIME. v.1. tema 5, p.394-402.

BJERRUM, L.; NASH, J.K.T.L.; KENNARD, R.M.; GIBSON, R.E. (1972). Hydraulic fracturing in filed permeability testing. Geotechnique. v. 22, p.319-332.

BRITO, P.A. de, DÉCOURT, L. (1970). O emprego de diafragma de solo-cimento na fundação da barragem de Ponte Nova. In: CONGRESSO BRASILEIRO DE MECÂNICA DOS SOLOS E ENGENHARIA DE FUNDAÇÕES, 4. Rio de Janeiro, 1970. Anais... São Paulo: ABMS. v.1. p.v-59-v71.

BUDWEG, F.M.G. et al. (1985). Rehabilitation of the Rasgão Dam. In: INTERNATIONAL CONGRESS ON LARGE DAM, 15., Lausanne, 1985. Transaction... Paris: ICOLD, 1985. v.4. p.171-190.

BUOSI, M.A.; CADMAM, J.D. (1984). Sobre a ocorrência de cavidades tubulares em solos lateríticos na região Amazônica. In: CONGRESSO BRASILEIRO DE GEOLOGIA DE ENGENHARIA, 4., Belo Horizonte, 1984. Anais... São Paulo: ABGE, 1984. v.3. Tema 3, p.19-24.

BURLAND, J.B.; MICHELL, J.M. (1989). The merits of polymeric fluids as support slurries. In: INTERNATIONAL CONFERENCE ON PILING AND DEEP FOUNDATIONS, 1989. London. Proceedings... Rotterdam: A.A. Balkema. v.1. p.3-10.

CADMAN, J.D.; BUOSI, M.A. (1985). Tubular cavities in the residual lateritic soil foundations of the Tucuruí, Balbina and Samuel hydroelectric dams in the Brasilian Amazon Region. In: INTERNATIONAL CONFERENCE ON GEOMECHANICS IN TROPICAL LATERITIC AND SAPROLITIC SOILS, 1., Brasília, 1985. Proceedings... São Paulo: ABMS. v.2. p.111122.

CAMPONUOVO, G.F.; FREDDI, A.; BORSETTO, M. (1980). Hydraulic fracturing of hot dry rocks: tridimensional studies of cracks propagation and interaction by photoelastic methods. Bergamo: Instituto Sperimentale Modelli e Strutture - ISMES. 10p.

CLARKE, W.J. (1982). Performance characteristics of acrylate polymer grout. In: CONFERENCE ON GROUTING IN GEOTECHNICAL ENGINEERING, New Orleans, 1982. Proceedings...New Orleans: ASCE, AIME. v.1, tema 5, p.418-432.

COOPER, M.M. et al. (1967). Response of a finite dimeter well to an instantaneous change of water. Water Resources Division, US Geological Survey, v.3, n.1.

CORRÊA FILHO, D.; QUADROS, E.F. de. (1987). Instrumento auxiliar de interpretação do comportamento hidrogeotécnico de maciços rochosos - obturador de impressão. In: CONGRESSO BRASILEIRO DE GEOLOGIA DE ENGENHARIA, 5., São Paulo, 1987. Anais... São Paulo: ABGE. v.1. tema 2, p.283-293.

COSTA NETO, P.L. de O. Estatística. São Paulo: Edgard Blücher, 1977. 264p.

CRUZ, P.T. (1996). 100 barragens brasileiras: casos históricos, materiais de construção e projeto. $1^{\mathrm{a}}$ ed. Oficina de Textos. 647p. 
CRUZ, P.T. Contribuição ao estudo do fluxo de água em meios contínuos e descontínuos. Volumes 1 , 2, 3, 5 e 8 (no prelo).

DEERE, D.U. (1982). Cement-bentonite grouting for dams. In: CONFERENCE ON GROUTING IN GEOTECHNICAL ENGINEERING. New Orleans, 1982. Proceedings... New Orleans: ASCE, AIME. v.1. tema 4, p.279-300.

DOMENICO, S.N. (1984). Rock lithology and porosity determination from shear and compressional wave velocity. Geophysics, v.49, n.8, p.1188-1195.

DOURADO, J.C. (1984). A utilização da sísmica na determinação de parâmetros elásticos de maciços rochosos e terrosos in situ. São Paulo: ABGE, 12p. (Publicação especial).

DOURADO, J.C. et al. (1994). O ensaio crosshole e as correlações com outros ensaios geotécnicos. In: CONGRESSO BRASILEIRO DE MECÂNICA DOS SOLOS E ENGENHARIA DE FUNDAÇÕES, 10 e SIMPÓSIO BRASILEIRO DE MECÂNICA DAS ROCHAS, 1., Foz do Iguaçu, 1994. Anais... São Paulo: ABMS, CBMR.

DUARTE, V.M. (1990). Caracterização hidrogeotécnica e injeção de vedação: tentativa de padronização de alguns critérios e procedimentos. In: CONGRESO SURAMERICANO DE MECANICA DE ROCAS, 3., Caracas, 1990. Memórias...Caracas: ISRM. p.253-262.

ELETRONORTE, MONASA, ENGE-RIO (1984a). Relatório sobre especificações complementares para execução da cortina de impermeabilização no solo residual e na rocha. fev. 1984a. (Relatório BAL-12-3441-EP).

ELETRONORTE, MONASA, ENGE-RIO (1984b). Relatório final de análise das injeções em solo residual e rocha alterada - Trecho experimental. ago. 1984b. (Relatório BAL-12-4705-RE).

ELETRONORTE, MONASA, ENGE-RIO (1985). Relatório histórico das decisões sobre tratamento das solos residuais na fundação da barragem de terra. abr. 1985. (Relatório BAL-12-3453$\mathrm{RE})$.

FRANCO, J.A.M., SANTOS, L.A.C.B. (1994). O tensor de tensões virgens da Serra da Mesa: a sua determinação pelo ensaio de fraturamento hidráulico. Solos e Rochas: Revista Brasileira de Geotecnia, São Paulo, v.17, n.3, p.167-180.

FUJISAWA, T.; NAKAMURA, A.; YAMAGUCHI, Y.; MATSUI, T. (1996). Development of fracture direction controlled grouting. In: YONEKURA, R.; TERASHI, M.; SHIBAZAKI, M. (eds). Grouting and deep mixing. Rotterdam: A.A. Balkema. p.689-694.

GAUSEREIDE, L.R., CASTRO, S., DELUCCHI, H. (1990). Ensayos de hidrofractura in situ y su importancia para el diseño de tuneles a presion no revestidos en el Proyecto Alfalfal, Chile. In: CONGRESO SURAMERICANO DE MECANICA DE ROCAS, 3., Caracas, 1990. Memorias... Caracas: ISRM. p.381-390.

GLOSSOP, R. (1960). The invention and development of injection processes. Part I: 1802-1850. Géotechnique, London, v.10, n. 3, p.91-100, Sep. 1960.

GLOSSOP, R. (1961). The invention and development of injection processes Part II: 1850-1960. Géotechnique, London, v.11, n. 4, p.255-279, Dec. 1961.

GOMBOSSY, Z.M., BARBA, A.L., SILVEIRA, G.N. (1981). Injeções de cimento na fundação da barragem principal de Itaipu. In: SEMINÁRIO NACIONAL DE GRANDES BARRAGENS, 14., Recife, 1981. Anais... Recife: CBGB. v.1, tema 2, p.225-245. 
GOURLAY, A.W.; CARSON, C.S. (1982). Grouting plant \& equipament. In: CONFERENCE ON GROUTING IN GEOTECHNICAL ENGINEERING. New Orleans, 1982. Proceedings... New Orleans: ASCE, AIME. v.1, tema 2, p.121-135.

GUIMARÃES FILHO, J.D. (1984). Consolidação de solos por injeções: discussão sobre uma prática bem sucedida mas que não está de acordo com as teorias clássicas existentes. Solos e Rochas: Revista Brasileira de Geotecnia, v.7, n.3, p.99-107.

HAIMSON, B.C. (1980). Near-surface and deep hydrofracturing stress measurements in the Waterloo Quartzite. International Journal Of Rock Mechanics and Mining Sciences \& Geomechanics Abstracts, v. 17, p.81-88.

HAIMSON, B.C. (1998). In situ stress measurements in the pre-excavation design stage of the Serra da Mesa hydroelectric project, Brazil. International Journal of Rock Mechanics and Mining Sciences \& Geomechanics, v. 35, p.4-5.

HAIMSON, B.C., FAIRHURST, C. (1967). Initiation and extension of hydraulic fractures in rocks. Society of Petroleum Enginners Journal, v.7, p.310-318.

HARPER, T.R.; HINDS, D.V. (1978). The impression packer: a toal for recovery of rock mass fracture geometry. In: BERGMAN, M. ed. Storage in escaveted rock caverns. Oxford: Pergamon Press, v.2, p.259-266. (Rockstone, 77).

HASUI, Y.; CARNEIRO, C.D.R.; BISTRICHI, C.A. (1978). Os granitos e granitóides da região de dobramentos sudeste nos Estados de São Paulo e Paraná. In: CONGRESSO BRASILEIRO DE GEOLOGIA, 30. Recife, 1978. Anais... São Paulo: SBG, v.6, p.2594-2608.

HAYASHI, K., SAKURAI, I. (1989). Interpretation of hydraulic fracturing shut-in curves for tectonic stress measurements. International Journal of Rock Mechanics and Mining Sciences \& Geomechanics Abstracts, v.26, n.6, Dec. 1989.

HOLANDA, F.G.; GUEDES, Q.M. (1981). Metodologia de ensaios de caldas ternárias para serviços de injeção. In: SEMINÁRIO NACIONAL DE GRANDES BARRAGENS, 14, Recife, 1981. Anais... São Paulo: SNGB, v.1, p.91-110.

HOSHIYA, M. et al. (1982). A new grouting material of Non-alkaline silica sol. In: CONFERENCE ON GROUTING IN GEOTECHNICAL ENGINEERING, New Orleans, 1982. Proceedings... New Orleans: ASCE, AIME, v.1, tema 5, p.378-393.

HOWARD, G.C. e FAST, C.R. (1970). Hydraulic fracturing. Society of Petroleum Engineers of AIME, v. 2. (Monograph).

HUBBERT, M.K., WILLIS, D.G. (1957). Mechanics of hydraulic fracturing. Petroleum Transactions AIME, v.210, p.153-168.

INFANTI JÚNIOR, N., NITTA, T. (1978). Considerações para reavaliação dos critérios de injeções de cimento. In: CONGRESSO BRASILEIRO DE GEOLOGIA DE ENGENHARIA, 2, São Paulo, 1978. Anais... São Paulo: ABGE, v.1, p.35-43.

INSTITUTO DE PESQUISAS TECNOLÓGICAS DO ESTADO DE SÃO PAULO. (1972). Estudos reológicos de caldas de cimento para injeção visando uma normalização de ensaios de laboratório. São Paulo: Divisão de Geologia. (IPT. Relatório, 6.290).

INSTITUTO DE PESQUISAS TECNOLÓGICAS DO ESTADO DE SÃO PAULO. (1979). Injeções em basalto. Relatório final. são Paulo: Divisão de Geologia. (IPT. Relatório, 12.513). 
INSTITUTO DE PESQUISAS TECNOLÓGICAS DO ESTADO DE SÃO PAULO. (1984a). A importância da reologia na aplicação de caldas de cimento. São Paulo: Divisão de Engenharia Civil. (IPT. Relatório, 19.559).

INSTITUTO DE PESQUISAS TECNOLÓGICAS DO ESTADO DE SÃO PAULO. (1984b). Geologia da Folha de Santana de Parnaíba (SF-23-Y-C-III-3), Estado de São Paulo. São Paulo: Divisão de Geologia. (IPT. Relatório, 20.767).

INSTITUTO DE PESQUISAS TECNOLÓGICAS DO ESTADO DE SÃO PAULO. (1989). Aplicação de ensaios sísmicos "cross hole" na avaliação de injeções em maciços terrosos. são Paulo: Divisão de Geologia. (IPT. Relatório, 27.432).

INTERNATIONAL SOCIETY FOR ROCK MECHANICS - ISRM. (1987). Suggested methods for rock stress determination. International Journal of Rock Mechanics and Mining Sciences \& Geomechanics Abstracts, v.24, n.1, p.54.

IYOMASA, W.S.(1994). Estudo geotécnico do município de Pirapora do Bom Jesus- SP. São Paulo. 137p. Dissertação (Mestrado) - Instituto de Geociências e Ciências Exatas, Universidade Estadual Paulista, Rio Claro.

IYOMASA, W.S., MELLO, L.G.F.S. de, MOTIDOME, M.J. (1997). Válvula de vedação para furos ascendentes, injeções de poliuretano e chumbadores de fibra de vidro. In: ENCONTRO TÉCNICO - TÚNEL DE PIRAPORA: ASPECTOS DE PROJETO E CONSTRUÇÃO, São Paulo, 1997. Anais... São Paulo: ELETROPAULO, p.197-204.

JEFFERIS, S.A. (1982). Effects of mixing on bentonite slurries and grouts. In: CONFERENCE ON GROUTING IN GEOTECHNICAL ENGINEERING, New Orleans, 1982. Proceedings... New Orleans: ASCE, AIME, v.1, tema 1, p.62-76.

JONES, G.K.(1963). Chemistry and flow properties of bentonite grouts. Grouts and drilling muds in engineering practice. Butterworths, London, p.22-28.

JURY, W.J. (1989). Considerações sobre a ocorrência de canalículos em locais de barragens na Região Amazônica. São Carlos. 76p. Dissertação (Mestrado) - Escola de Engenharia de São Carlos, Universidade de São Paulo.

JURY, W.J., PARAGUASSU, A.B. (1990). Considerações sobre a ocorrência de canalículos em locais de barragens na Região Amazônica. In: CONGRESSO BRASILEIRO DE GEOLOGIA DE ENGENHARIA, 6, CONGRESSO BRASILEIRO DE MECÂNICA DOS SOLOS E ENGENHARIA DE FUNDAÇÕES, 9., Salvador, 1990. Anais... São Paulo: ABGE, ABMS. v.1, p.511-518.

KANJI, M.A. (1990). Fundacion de presas en rocas blandas y rocas fracturadas: problemas y soluciones. In: CONGRESO SURAMERICANO DE MECANICA DE ROCAS, 3., Caracas, 1990. Memorias... Caracas: ISRM. p.235-252.

KAROL, R.H. (1982). Chemical grouts and their properties. In: CONFERENCE ON GROUTING IN GEOTECHNICAL ENGINEERING, New Orleans, 1982. Proceedings... New Orleans: ASCE, AIME, v.1, tema 5, p.359-377.

LANDIM, P. M. B. (1998). Análise estatística de dados geológicos. São Paulo, UNESP.

LENCASTRE, A. Manual de hidráulica geral. São Paulo: Edgard Blücher, 1972.

LE TIRANT, P.; GAY, L. (1972). Manuel de fracturation hydraulique. Parsi, 1972. (Collection pratique du pétrole, 5, - Édition Techniq). 1972. 
LOUIS, C. (1969). Etude des ecoulements d'leaudams le roche fissure et leur influences sur la stabilité des massifs rochers. Bulletin de la Direction des Etude et Recherche, Sene A. (These presenteé a l’Université de Korlsruhe).

MACHADO, T.de S., MYEGRE, J.C. de, POCIOTTI, P.C. (1984). Injeção de cimento na fundação da barragem de Emborcação. In: CONGRESSO BRASILEIRO DE GEOLOGIA DE ENGENHARIA, 4., Belo Horizonte, 1984. Anais... São Paulo: ABGE, v.3, p.65-84.

MANO, V.G.T., PALAZZO NETO, P. (1981). Tratamento da fundação da barragem de enrocamento da usina Nova Avanhandava - rio Tietê, SP. In: CONGRESSO BRASILEIRO DE GEOLOGIA DE ENGENHARIA, 3., Itapema, 1981. Anais... São Paulo: ABGE, v.2, p.33-44.

MARRANO, A.; GUEDES, M.G.; MATSUMURA, T.; GRAEFF, L.O. (1984). Cortinas de injeção e drenagem na fundação das estruturas de concreto de Aproveitamento Múltiplo de Nova Avanhandava. In: CONGRESSO BRASILEIRO DE GEOLOGIA DE ENGENHARIA, 4., Belo Horizonte, 1984. Anais... São Paulo: ABGE, v.3, p.87-112.

MATSUMOTO, N.; NAKAMURA, A.; YAMAGUCHI, Y.; ONUMA, E.; HASHIMOTO, T.; YAMAGATA, H. (1996). Development of grouting material for cement powder grouting. In: YONEKURA, R.; TERASHI, M.; SHIBAZAKI, M. (eds). Grouting and deep mixing. Rotterdam: A.A. Balkema, p.59-64.

MATTOS, G., SATHLER, G., HOLANDA, F.G. (1981). Comentários sobre alguns critérios de execução de injeções de cimento. In: CONGRESSO BRASILEIRO DE GEOLOGIA DE ENGENHARIA, 3., Itapema, 1981. Anais... São Paulo: ABGE, v.1, p.105-116.

MELLO, F.M. de et al. (1990). Reativação da usina hidrelétrica de Rasgão. In: HYDRO 90 SMALL/MEDIUM. São Paulo, 1990. Anais... São Paulo: CESP, ELETROPAULO, CPFL, HRC. p.249-260.

MELLO, L.G.F.S. de, FRANCO FILHO, J.M.M., ALVISE, C. (1987). O tratamento de solos residuais condicionados por canalículos: um caso de obra. In: CONFERÊNCIA IBEROAMERICANA SOBRE APROVEITAMENTO HIDRÁULICOS, 1., Lisboa, 1987. Anais... Lisboa: LNEC, v.1, p.1-12.

MELLO, L.G.F.S. de, FRANCO FILHO, J.M.M., ALVISE, C. (1988). Grouting of canaliculae in residual soils and behaviour of the foundations of Balbina Dam. In: INTERNATIONAL CONFERENCE ON GEOMECHANICS IN TROPICAL SOILS, 2., Singapore, 1988. Proceedings...Rotterdam: A.A. Balkema, v.2, p.385-389.

MOREIRA, J.E. et al. (1990). Comportamento dos tratamentos de fundação das barragens de terra de Balbina. In: CONGRESSO BRASILEIRO DE GEOLOGIA DE ENGENHARIA, 6; CONGRESSO BRASILEIRO DE MECÂNICA DE SOLOS E FUNDAÇÕES, 9., Salvador, 1990. Anais... Salvador: ABGE, ABMS, v.1, p. 577-588.

OLIVEIRA, M.; FERREIRA, A.A. (1982). Consolidação de solo aluvionar mole: relato de um tratamento por injeção de cimento para escavação de túnel urbano na cidade de São Paulo. In: SIMPÓSIO SOBRE ESCAVAÇÕES SUBTERRÂNEAS, Rio de Janeiro, 1982. Anais... São Paulo: ABMS, v.1, p.335-353.

PASTORE, E. L. (1998). Engineering geology of soil mass foundations of some concrete gravity dams in Brasil. In: CONGRESS OF THE INTERNATIONAL ASSOCIATION FOR ENGINEERING GEOLOGY AND THE ENVIRONMENT, 8., Vancouver, 1998. Proceedings... Rotterdam: A.A. Balkema, v.5, p.3191-3196.

PITTA, M.R. ( 1984). Dosagem de lama de solo-cimento para injeção. São Paulo: ABCP, 6p. (Boletim Técnico, 96). 
PRADO, R.L. (1994). O ensaio sísmico entre furos (crosshole) no estudo de maciços terrosos e rochosos. 123p. Dissertação (Mestrado) - Instituto de Astronomia e Geofísica, Universidade de São Paulo.

PRADO, R.L.; IYOMASA, W.S.; DOURADO, J.C.; CORDEIRO, R.P. (1989). Contribuição do ensaio sísmico cross hole na avaliação de injeções de solo-cimento em maciços terrosos. In: CONGRESSO DA SOCIEDADE BRASILEIRA DE GEOFÍSICA, 1., Rio de Janeiro, 1989. Anais... São Paulo: SBGf, v.3, p.1321-1326.

PROGECONSULT (1997). - Projeto, Gerenciamento e Consultoria de Engenharia S/C Ltda. Relatório Técnico - Tratamento por injeções das fundações do laboratório, caixa d'água e casa das caldeiras: apresentação e análise dos dados obtidos durante a execução dos serviços. p.14.

QUADROS, E.F. de.(1982). Determinação das características do fluxo de água em fraturas de rochas. 236p. Dissertação (Mestrado) - Escola Politécnica, Universidade de São Paulo.

RÉ, G. (1976). O tratamento das fundações da Usina de Ilha Solteira e análise do seu comportamento no controle das subpressões. São Paulo: Themag Engenharia. 38p.

REED, A.C.; DUSSEAULT, M.B. (1997). Hydraulic fracturing of soil as na analogue to rock behaviour. International Journal of Rock Mechanics and Mining Sciences, New York: $36^{\text {th }}$ U.S. Rock Mechanics Symposium, v. 34, 3/4.

RÉMY, J.P.P. et al. (1985). Choice of the fundation treatment of the Balbina Earth Dam. In: INTERNATIONAL CONGRESS ON LARGE DAMS, 15., Lausanne, 1985. Transactions... Paris: ICOLD, 1985. v.3, p.263-283.

RIBEIRO, T.S.M.T. (1997). Curso: River \& Dam Engineering II promovido pela Japan International Cooperation Agency - JICA, Ago.96 - nov. 96, 28p. (CESP Relatório Interno).

RICCOMINI, C. (1989). O rift continental do Sudeste do Brasil. São Paulo, 256p. Tese (Doutorado) - Instituto de Geociências, Universidade de São Paulo.

SABARLY F. (1968). Les injections et les drainages de foundations de barrages en roches peu permeables. Geotechnique, v.18, n.2. p.229-249. Trad. de Guido Guidicini e Fernão Paes de Barros, 1971, São Paulo. (APGA. Boletim, 2).

SAMPAIO, A.J.M. (1976). Análise dos tratamentos e das percolações na fundação da soleira do vertedor da barragem de Capivara, rio Paranapanema. In: SEMINÁRIO NACIONAL DE GRANDES BARRAGENS, 11., Fortaleza, 1976. Anais... Fortaleza: CBGB, v.2, p.773-795.

SAMPAIO, A.J.M. (1988). O emprego de injeção de calda de cimento no tratamento de fundações basálticas de barragens do tipo concreto-gravidade no Brasil Meridional: aspectos práticos. São Carlos. 118p. Dissertação (Mestrado) - Escola de Engenharia de São Carlos, Universidade de São Paulo.

SANTORO, E. (1984). Geologia da Folha de Cabreuva, SP. São Paulo, 144p. Dissertação (Mestrado) - Instituto de Geociências, Universidade de São Paulo.

SANTOS, O.G. dos et al. (1985). Experimental grouting of residual soil of the Balbina Earth Dam Foundation, Amazon, Brazil. In: INTERNATIONAL CONFERENCE ON GEOMECHANICS IN TROPICAL LATERITIC AND SAPROLITIC SOILS, 1., Brasília, 1985. Proceedings... São Paulo: ABMS, v.2, p.143-154. 
SATHLER, G.; MESQUITA, J.B. (1984). Canalículos, sugestão de classificação e de metodologia de investigações de campo. In: CONGRESSO BRASILEIRO DE GEOLOGIA DE ENGENHARIA, 4., Belo Horizonte, 1984. Anais... São Paulo: ABGE, v.3, p.407-414.

SERRA JÚNIOR, E. (1991). Equipamentos de sondagens rotativas para amostragem de rochas brandas em investigação geológico-geotécnica. São Carlos. 105p. Dissertação (Mestrado) Escola de Engenharia de São Carlos, Universidade de São Paulo.

SHAMES, I.H. (1973). Mecânica dos fluidos. São Paulo: Edgard Blücher.

SIQUEIRA, G.H., BABA, L.J.N., SIQUEIRA, J.M. de, (1986). Foundation treatment of the earth dam of the Balbina hydroelectric Power Plant grouting with hydraulic in residual soil. In: INTERNATIONAL CONGRESS OF THE INTERNATIONAL ASSOCIATION OF ENGINEERING GEOLOGY, 5., Buenos Aires, 1986. Proceedings... Rotterdam: A.A. Balkema, v.2, p.559-570.

TATAMIYA, C.T. et al.(1971). Ensaios in situ de injeção de caldas de cimento nas fundações da Usina de Ilha Solteira. In: SEMINÁRIO NACIONAL DE GRANDES BARRAGENS, 7., Rio de Janeiro, 1971. Anais... Rio de Janeiro: CBGB, v.1, p.196-199.

TAKEBAYASHI, S. et al. (1996). Applicability of cement powder grouting method. In: YONEKURA, R.; TERASHI, M.; SHIBAZAKI, M. (eds). Grouting and deep mixing. Rotterdam: A.A. Balkema, p.83-88.

TURK, N.; DEARMAN, W.R. (1987). Assessment of grouting efficiency in a rock mass in terms of seismic velocities. Bulletin of IAG, n.36, p.101-108.

WAENY, J.C.C. (1980). Recomendações para determinação de intervalo de confiança. São Paulo: IPT, 1980. 25p. (IPT. Publicação, 1160).

WERNECK, M. L. G. (1975). Some considerations on the use of hydraulic fracture tests in partly saturated embankment fills. In: PANAMERICAN CONFERENCE ON SOIL MECHANICS AND FOUNDATION ENGINEERING, 5. Proceedings... Buenos Aires, v. 2, p.179-188.

WYLIE, M.R.J.; GREGORY, A.R.; GARDNER, L.W. (1956). Elastic wave velocities in heterogeneous and porous media. Geophysics, v.21, n.1, p.41-70, jan. 1956. 